PNL-2964

UC-90i

\title{
Air Quality Measurements in the Coal-Fired Power Plant Environment of Colstrip, Montana
}
J. D. Ludwick
D. B. Weber
K. B. Olsen
S. R. Garcia

July 1979

Prepared for the

Environmental Protection Agency

under a Related Services Agreement

with the Department of Energy

under Contract EY-76-C-06-1830

Pacific Northwest Laboratory

Operated for the U.S. Department of Energy

by Battelle Memorial Institute 


\title{
NOTICE
}

This report was prepared as an account of work sponsored by the United States Covernment. Neither the United States nor the Department of Energy, nor any of their employees, nor any of their contractors, subcontractors, or their employees, makes any warranty, express or implied, or assumes any legal liability or responsibility for the accuracy, completeness or usefulness of any information, apparatus, product or procesa disclosed, or represents that its use would not infringe privately owned rights.

The views, opinions and conclusions contained in this repon are those of the contractor and do not necessarily represent those of the United States Government or the United States Department of Energy.

\author{
PACIFIC NORTHWEST LABORATORY \\ operated by \\ BATTELLE \\ for the \\ UNITED STATES DEPARTMENT OF ENERGY \\ Under Contract EY-76-C-06-7830
}
Printed in the United States of America
Available from
National Technical Information Service
United States Department of Commerce
5285 Port Royal Road
Springtield, Virginia 22151

Price: Printed Copy 5

*i. Microtiche $\$ 3.00$

NTIS

- Pager Selling Price

$\begin{array}{ll}001-025 & \$ 4.00 \\ 026-050 & \$ 4.50 \\ 051-075 & \$ 5.25 \\ 076.100 & \$ 6.00 \\ 101-125 & \$ 6.50 \\ 176-150 & \$ 7.25 \\ 151.175 & \$ 4.00 \\ 176.200 & \$ 9.00 \\ 201.225 & \$ 9.25 \\ 276.250 & \$ 9.50 \\ 251-275 & \$ 10.75 \\ 276-300 & \$ 1100\end{array}$




\section{2}

AIR QUALITY MEASUREMENTS IN THE COAL-FIRED POWER PLANT ENVIRONMENT OF COLSTRIP, MONTANA
J. D. Ludwick
D. B. Weber
K. B. Olsen
S. R. Garcia

July 1979

Prepared for the Environmental Protection Agency under a Related Services Agreement with the Department of Energy under Contract EY-76-C-06-1830

Pacific Northwest Laboratory

Richland, Washington 99352 


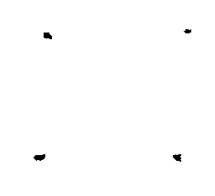




\section{ABSTRACT}

A network of up to six air monitoring and sampling stations were operated 4-23 km downwind of the $700 \mathrm{Mli}$ coal-fired power plants at Colstrip, Montana. Continuous monitoring identified background $\mathrm{SO}_{2}$ levels in the surrounding air at approximately $1 \mathrm{ppb}\left(2.3 \mathrm{\mu g} / \mathrm{m}^{3}\right)$. Average air concentrations measured in 1978 throughout the network increased to about 2 $\mathrm{ppb}\left(4.6 \mu \mathrm{g} / \mathrm{m}^{3}\right)$ as a result of power plant operations. Meteorological and aerosol correlations with $\mathrm{SO}_{2}$ concentrations helped identify and isolate the major source. The high sensitivity for $\mathrm{SO}_{2}$ measurement provided resolution of all significant power plant plume fumigations at ground level. The magnitude of $\mathrm{SO}_{2}$ exposures were higher than predicted in this rough terrain environment. 



\section{CONTENTS}

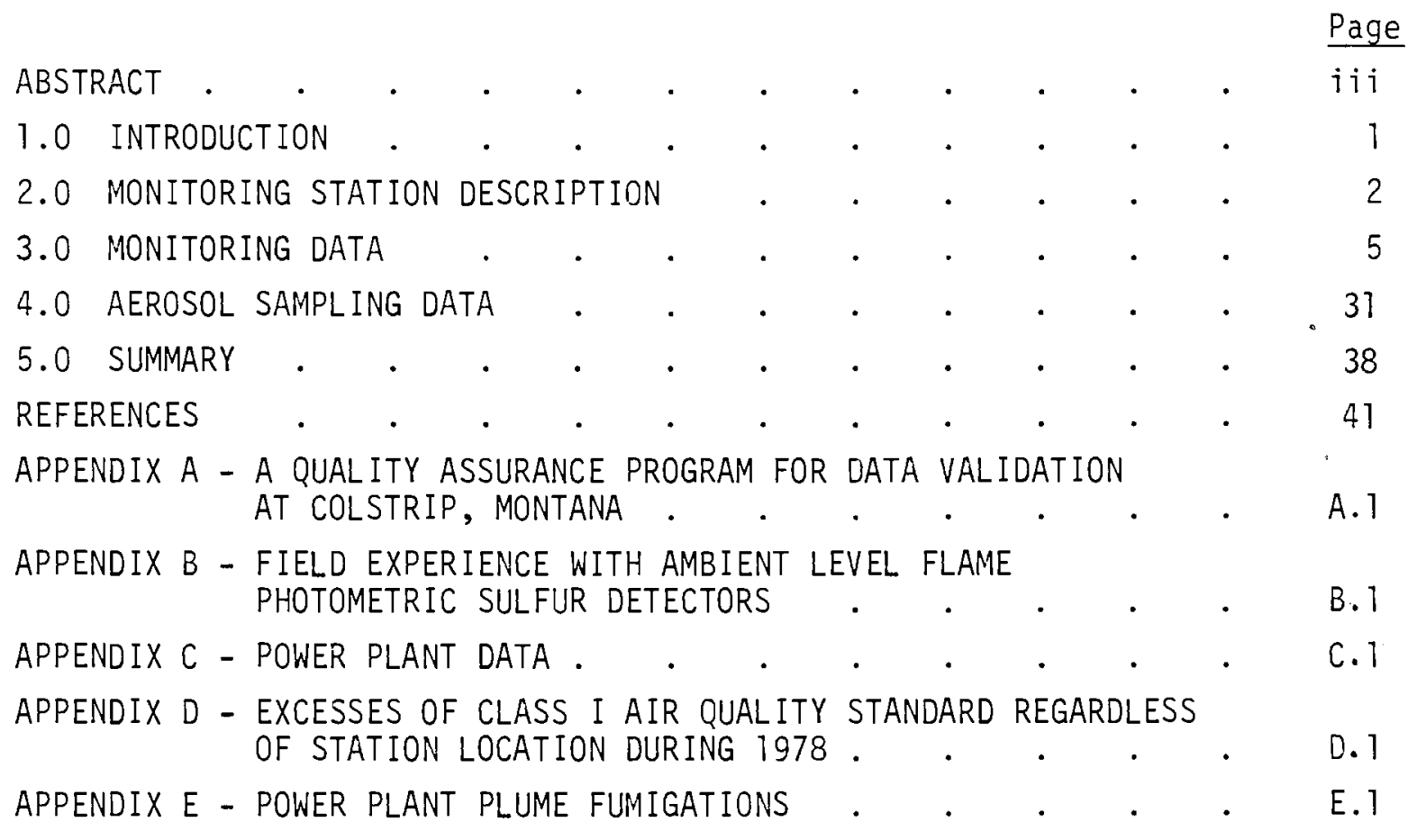




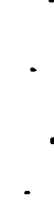




\section{LIST OF FIGURES}

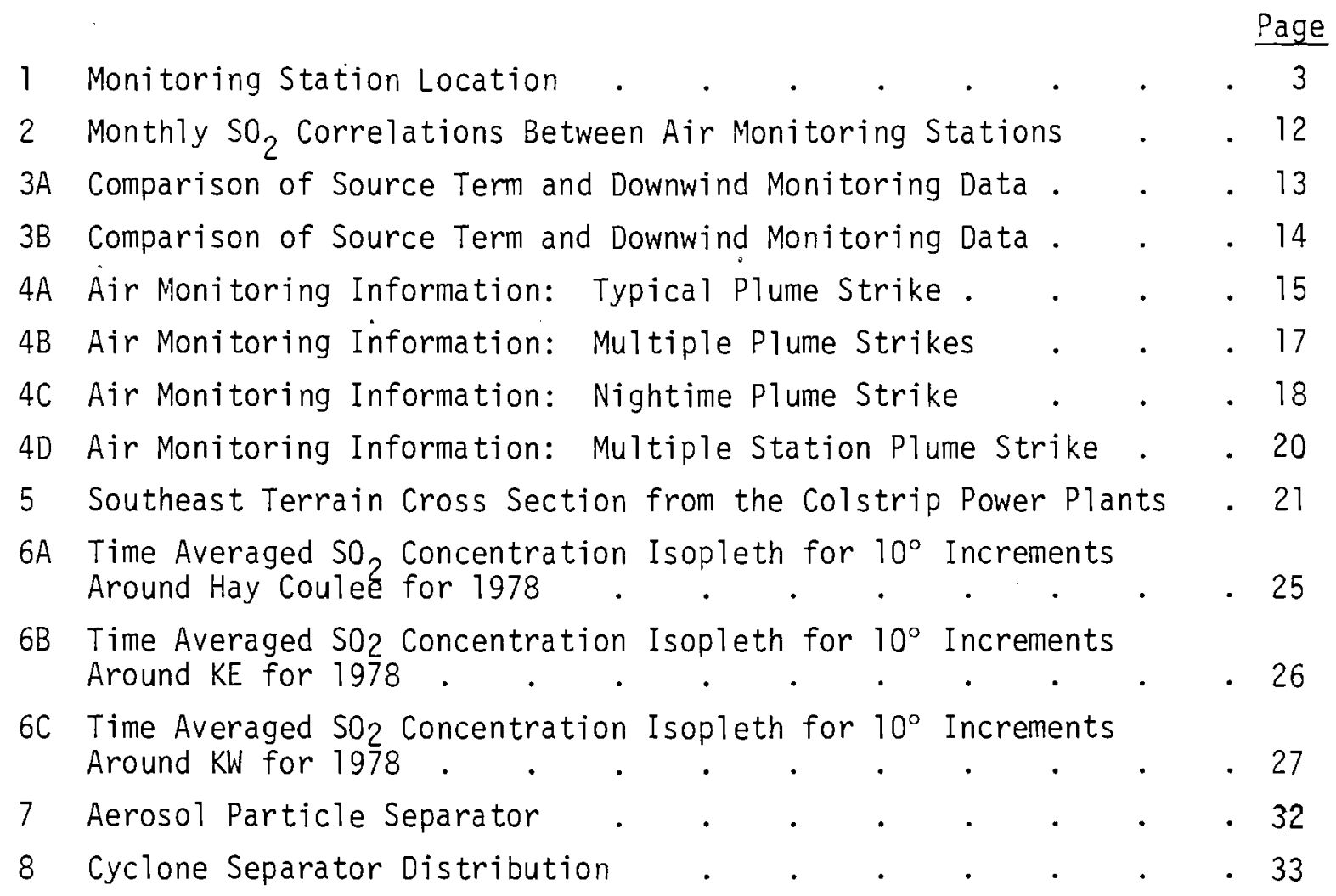





\section{LIST OF TABLES}

1 A Hay Coulee Monthly Averages Page

IB Kluver East Monthly Averages . . . . . . . . 47

1C Kluver West Monthly Averages . . . . . . . . 8

10 BNW-1 Monthly Averages . . . . . . . . . . . . . . 9

2 Sulfur Dioxide Air Quality Standards . . . . . 10

Diffusion Model Predictions Versus Measured Hourly
Averaged $\left(\mathrm{SO}_{2}\right)$. . . . . . .

4 Frequency Occurrence of Elevated $\mathrm{SO}_{2}$ Exposures

5 Frequency Distribution of $\mathrm{SO}_{2}$ Exposures in the

6 Air Monitoring Data Averages for 1978 . . . . 30

7 January 1978 Colstrip Aerosol Concentrations $\mathrm{ng} / \mathrm{m}^{3} \quad$. 34

8 Elemental Distributions in Colstrip Area Aerosols . . 36

$9 \begin{aligned} & \text { Aerosol Size Distributions in } \mathrm{SO}_{2} \text { Polluted Air on } \\ & \text { Strike Days } . \quad . \quad . \quad . \quad . \quad . \quad . \quad . \quad . \quad 37\end{aligned}$

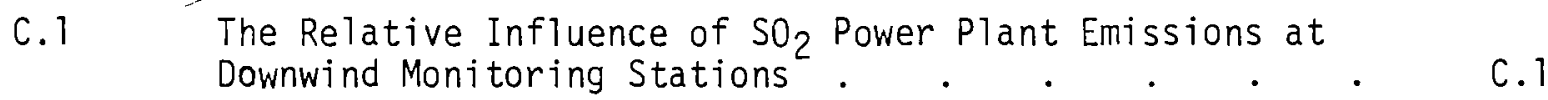

C.2.A - Colstrip Unit \#1 Emission Data (January 1978). . . . C.2

C.2.B Colstrip Unit \#2 Emission Data (January 1978). . . . C.3

C.3.A Colstrip Unit \#1 Emission Data (February 1978) . . . C.4

C.3.B Colstrip Unit \#2 Emission Data (February 1978) . . C C.5

C.4.A Colstrip Unit \#1 Emission Data (March 1978) . . . . C.6

C.4.B Colstrip Unit \#2 Emission Data (March 1978) . . . . C.7

C.5.A Colstrip Unit \#1 Emission Data (Apri1 1978) . . . . C.8

C.5.B Colstrip Unit \#2 Emission Data (April 1978) . . . . C C.9

C.6.A Colstrip Unit \#1 Emission Data (May 1978) . . . . C.10

C.6.B Colstrip Unit \#2 Emission Data (May 1978) . . . . C C.11

C.7.A Colstrip Unit \#1 Emission Data (June 1978) . . . . C.12

C.7.B Colstrip Unit \#2 Emission Data (June 1978) . . . . . C.13

C.8.A Colstrip Unit \#1 Emission Data (July 1978) . . . . C.14

C.8.B Colstrip Unit \#2 Emission Data (July 1978) . . . . C.15

C.9.A Colstrip Unit \#1 Emission Data (August 1978) . . . . C.16

C.9.B Colstrip Unit \#2 Emission Data (August 1978) . . . . C.17 
$\underline{\text { Page }}$

C.10.A Colstrip Unit \#1 Emission Data (September 1978) . . C.18

C.10.B Colstrip Unit \#2 Emission Data (September 1978) . . C.19

C.11.A Colstrip Unit \#1 Emission Data (October 1978) . . C.20

C.11.B Colstrip Unit \#2 Emission Data (October 1978) . . C C.21

C.12.A Colstrip Unit \#1 Emission Data (November 1978) . . C.22

C.12.B Colstrip Unit \#2 Emission Data (November 1978) . . C.23

C.13.A Colstrip Unit \#i Emission Data (December 1978) . . C C.24

C.13.B Colstrip Unit \#2 Emission Data (December 1978) . . C. C.25

D.1 Excesses of Class 1 Air Quality Standard Regardless of Station Location During 1978 ... .5 .1$

E.1 Power Plant Plume Intercepts at Hay Coulee . . . E.1

E.2 Power Plant Plume Intercepts BNW \#1 . . . . . . E.8

E.3.A Power Plant Plume Intercepts Kluver West . . . E.16

E.3.B Power Plant Plume Intercepts Kluver West . . . E.17

E.3.C Power Plant Plume Intercepts Kluver North . . . E.17

E.4 Power Plant Plume Intercepts at Greenleaf . . . E.18 


\subsection{INTRODUCTION}

Results are reported from an air sampling and monitoring network operating in the eastern portion of the State of Montana during 1978. This program is an expansion and sophistication of earlier attempts to characterize the air quality downwind of the two coal-fired power plants at Colstrip, Montana (700 MW). A year of continuous operations has yielded data which include significant environmental effects from operation of these power plants 4-23 km downwind. The atmospheric models presently used to estimate pollutant exposures in this rough terrain environment appear to have underestimated the frequency and intensity of power plant emission exposures at the more distant locations.

Long-term studies have been reported concerning the downwind ground level concentration of sulfur dioxide in the coal-fired power plant environment. $(1,2,3,4)$ In general, these studies have taken place in areas of considerable pollution, where high background levels must be tolerated. Additional problems relating to instrumental sensitivity capabilities in real time have limited the detection of low-level plume fumigation. Lack of instrumental sensitivities may be responsible for high background estimates reported at locations where incoming air appears to have no obvious pollution source. (5) Long distance transport (100 km) of sulfur dioxide from major industrial regions has been reported, however, and the influence of such sources must be considered in some situations. ( $(E)$ In spite of elevated levels of sulfur dioxide in the background, meterological correlations have helped identify the larger sources in many instances. $(7,8)$

The Great Plains contains a vast reservoir of fossilized energy. The most direct purpose for its use is in supplying the power needs of the region it underlies. It is anticipated that the expanded use of coal for supplying electrical power will present environmental problems which must be addressed. In the colstrip area a consortium of public utilities has site applications 
which propose to triple the generating capacity of this area with two additional units. Each of these proposed power plants will have the combined capacity of the two original units. Experimental data such as that reported here, as well as much more, will be necessary to provide accurate siting criteria information on the expected impact of large pollutant emitters. The bulk of the air-monitoring and sampling data reported here includes the entire year of 1978 .

A review of the collected data illustrates the sensitivity of the air monitoring stations to assess the sulfur dioxide impact upon the downwind environment. As a result of the success in ambient-level air quality measurements, pertinent data are available to estimate the extent of the power plant impact upon the class 1 region located adjacent to our more distant monitoring stations.

\subsection{MONITORING STATION DESCRIPTION}

The relative positions of the air-monitoring stations and the power piant are shown in Figure 1. Not more than four sites were operated simultaneously. The initial site locations selected were based upon a windrose analysis of this area. Although all stations were not identical in capability, a typical station description follows.

Air monitoring was conducted on oxides of sulfur utilizing a Meloy Model 285 sulfur analyzer which was selected for its low noise characteristics. This was particularly significant since the bulk of the ambient data was expected to be below $10 \mathrm{ppb}\left(23 \mu \mathrm{g} / \mathrm{m}^{3}\right)$. Ozone levels were measured with a Bendix Model 8002 ambient air analyzer. Particulates were monitored with a Model Rich 100 Environment/One Condensation Nuclei Detector. Ambient air was supplied to the monitoring instrumentation from a common Teflon manifold. High velocity flow was maintained through this manifold. Information from the air monitoring equipment, as well as data from meteorological instrumentation located at the sites, were collected by a microprocessor/datalogger and interfaced to a paper punch tape for storage and computer processing. The 


\section{FIGURE 1 \\ MONITORING STATION LOCATION}

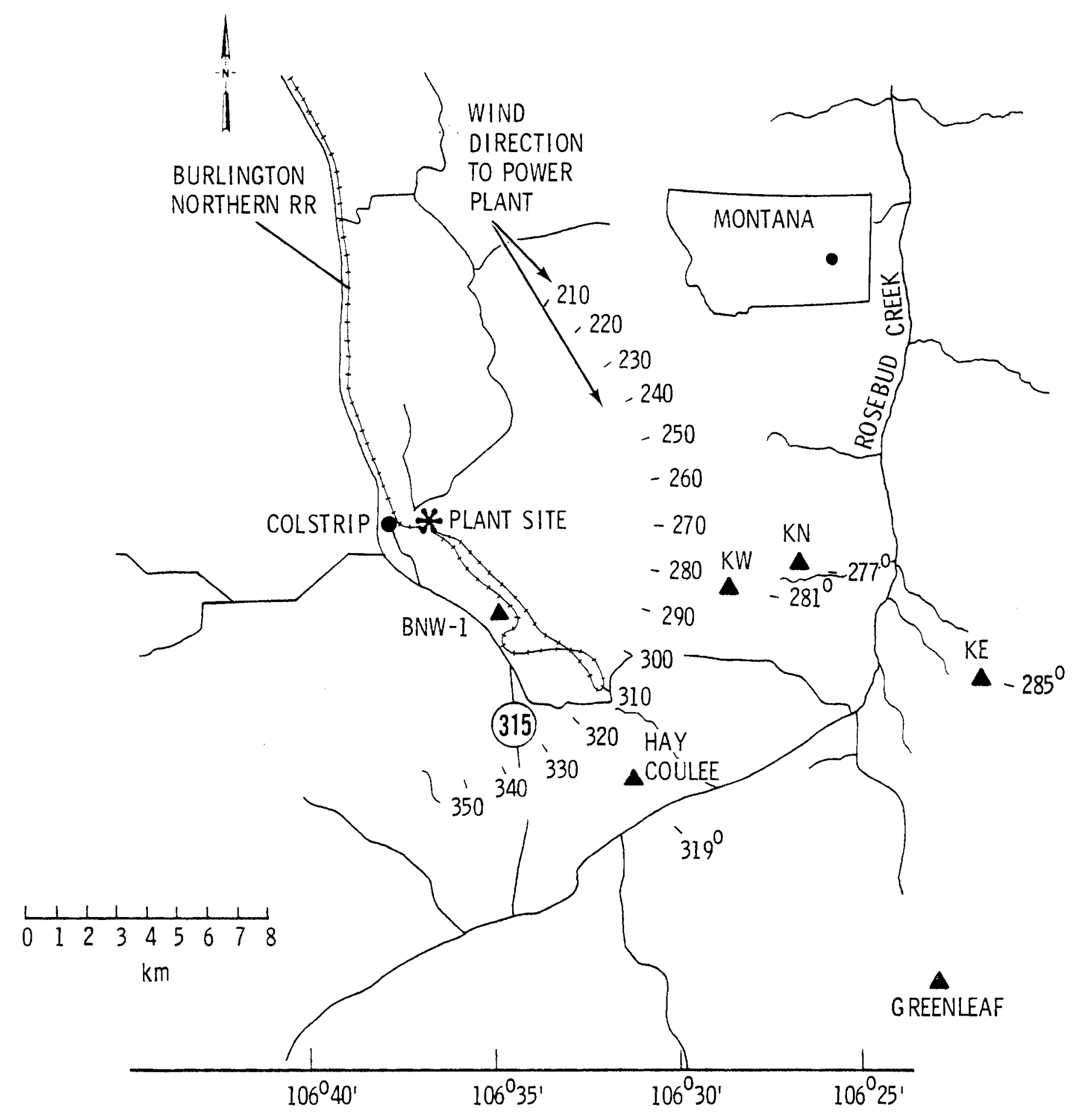


meteorological information included windspeed and direction, temperature, humidity and solar radiation. All the equipment was housed in small, highly insulated trailers. Electrical power for most stations was derived from 5.5 $\mathrm{kW}$ propane-fueled generators. The power was divided into two sections: rough power for the heating, air conditioning, and pumps as well as stable power for the instrumentation. An uninterruptible power system supplied highly regulated $115-$ volt $60-\mathrm{Hz}$ electricity necessary for the stable operation of the air-monitoring instrumentation. This equipment also provided power continuity for station operation during periods of short-term generator outage. One thousand-gallon storage containers provided a 45-day fuel supply for the generators. This was necessitated by the inaccessibility of some of the stations during the winter months in Montana.

A two-stage cyclone separator was operated in conjunction with the monitoring instrumentation. This provided particulate information which could be correlated with the gas data. The air-monitoring data were collected in increments of 4 minutes and these values were averaged for different pertinent intervals. The data was edited for spurious information and instrumental fluctuations.

A quality assurance program for verifying the integrity of the collected air-monitoring data was in effect throughout the operation of this program. Rockwell International, under contract from the Environmental Protection Agency (EPA), performed quarterly audits on a routine basis. The extent of each audit included all operational air-monitoring instrumentation and other calibration equipment at the sites visited. A record of the audit reports is included in Appendix $A$. During the course of these audits, relatively minor problems were identified in both the auditors' procedures and the field calibration techniques. Field experiments relating to the interesting problem of carbon dioxide interference in sulfur dioxide measurements during audits is also reported in Appendix B. Although the audits were useful in identifying problems, unfortunately no effort was made by the auditors to correct published audits even after field personnel identified errors in prior auditing procedures. A complete record of the instrumental calibration program may be found as a final item in Appendix $A$. 


\subsection{MONITORING DATA}

The monthly averages of the data are shown in Tables 1A, 1B, 1C, and 1D. The concentrations of sulfur dioxide are quite low, with respect to the urban environment. Except for individual short-term events discussed later, the impact of oxides of nitrogen from the power plant upon the ozone averages would be masked by the ubiquitous ambient levels of this species. This same argument is valid for the monthly averaged condensation nuclei levels whose concentrations may be better correlated with atmospheric stability or winds, rather than the power plant plume. Each of these latter factors serve to overwhelm the plume particulate in the lower tropospheric levels. In general, the levels of ozone and particulate are consistent with those observed in other relatively clean environments. (9)

The concentrations fluctuations of gaseous sulfur at the stations is sufficient in some instances to be of interest. For example, in March the averaged sulfur dioxide concentrations at Hay Coulee, 7.5 miles from the power plant was $5.6 \mathrm{ppb}$. This represents a contribution of almost $0.5 \mathrm{ppb}$ on an annually averaged basis from this single month. The Northern Cheyenne Indian Reservation extends to within 14 miles of the power plant, in the same general direction as Hay Coulee. This land bears a Class 1 air quality designation. With reference to Table 2, the Air Quality Standards, we see that an elevation of no more than $0.7 \mathrm{ppb}$ is acceptable before significant air quality deterioration is suggested. Since values of this magnitude were not expected from EPA models utilized in this area, the question of the sulfur dioxide source and downwind diTution between 7 and 14 miles becomes rather important.

No reliable ambient sulfur dioxide background measurements are available prior to power plant operation. These data suggest that averaged present day background levels decline to about $0.7 \mathrm{ppb}$ and are typically about $1 \mathrm{ppb}$ $\left(2.37 \mathrm{\mu g} / \mathrm{m}^{3}\right)$. Values of this magnitude correspond to those observed in the cleanest areas of industrialized nations. (10) Assuming this to be a reasonable conservative minimum, the magnitude of the effect from a pollution source can then be considered. Lower background estimates would, of course, infer more potent anthropogenic sulfur dioxide sources. A summation and averaging of this data on an annual basis indicate that both KE and KW stations observed an 
TABLE 1A

\section{HAY COULEE MONTHLY AVERAGES}

\begin{tabular}{|c|c|c|c|c|c|c|}
\hline DATE & $\begin{array}{c}\text { WIND } \\
\text { SPEED } \\
\text { mph }\end{array}$ & $\begin{array}{c}\text { RELATIVE } \\
\text { HUMIDITY } \\
\%\end{array}$ & $\begin{array}{l}\text { TEMPERATURE } \\
{ }^{0} \mathrm{C}\end{array}$ & $\begin{array}{l}\text { OZONE } \\
\mathrm{ppb}\end{array}$ & $\begin{array}{l}\mathrm{SO}_{2} \\
\mathrm{ppb}\end{array}$ & $\begin{array}{c}100 \times L O G(C C N) \\
C C N / C C\end{array}$ \\
\hline $2 / 78$ & 4.2 & 70.9 & -11.2 & 43 & 3.7 & 351 \\
\hline $3 / 78$ & 4.2 & 61.3 & -2.4 & 42 & 5.6 & 313 \\
\hline $4 / 78$ & 7.6 & 54.6 & 8.2 & 39 & 1.8 & 246 \\
\hline $5 / 78$ & 6.5 & 68.2 & 12.6 & 41 & 1.3 & 167 \\
\hline $6 / 78$ & 5.7 & 56.6 & 19.4 & 40 & 2.3 & 288 \\
\hline 7178 & 5.4 & 52.4 & 24.1 & 43 & 1.6 & --- \\
\hline $8 / 78$ & 5.5 & 43.0 & 22.3 & 33 & 1.0 & --- \\
\hline $9 / 78$ & 5.6 & 56.0 & 15.8 & 28 & 1.5 & -.- \\
\hline $10 / 78$ & 4.6 & 50.0 & 7.3 & 27 & 1.7 & --- \\
\hline $11 / 78$ & 3.4 & 61.5 & -8.7 & 33 & 1.5 & --- \\
\hline $12 / 78$ & 5.7 & 55.4 & -13.0 & 34 & 1.7 & --- \\
\hline
\end{tabular}




\section{TABLE 1B KLUVER EAST MONTHLY AVERAGES}

\begin{tabular}{|c|c|c|c|c|}
\hline DATE & $\begin{array}{c}\text { TEMPERATURE } \\
{ }^{0} \mathrm{C} \\
\end{array}$ & $\begin{array}{c}\text { OZONE } \\
\mathrm{ppb} \\
\end{array}$ & $\begin{array}{l}\mathrm{SO}_{2} \\
\mathrm{ppb} \\
\end{array}$ & $\begin{array}{c}100 \times \mathrm{LOG}(\mathrm{CCN}) \\
\mathrm{CCN} / \mathrm{CC}\end{array}$ \\
\hline $3 / 78$ & 8.9 & 40 & 1.8 & 337 \\
\hline $4 / 78$ & 9.1 & 39 & 1.8 & 302 \\
\hline $5 / 78$ & 12.3 & 45 & 2.2 & 272 \\
\hline $6 / 78$ & 16.5 & 39 & 3.4 & 254 \\
\hline $7 / 78$ & 27.4 & 46 & --- & -- \\
\hline $8 / 78$ & 22.3 & 36 & 1.4 & --- \\
\hline $9 / 78$ & 18.9 & 30 & 0.9 & $-\cdots$ \\
\hline $10 / 78$ & 12.3 & 32 & 0.7 & -- \\
\hline
\end{tabular}




\section{TABLE 1C \\ KLUVER WEST MONTHLY AVERAGES}

\begin{tabular}{|c|c|c|c|c|}
\hline DATE & $\begin{array}{l}\text { TEMPERATURE } \\
{ }^{0} \mathrm{C} \\
\end{array}$ & $\begin{array}{c}\text { OZONE } \\
\mathrm{ppb}\end{array}$ & $\begin{array}{l}\mathrm{SO}_{2} \\
\mathrm{ppb} \\
\end{array}$ & $\begin{array}{c}100 \times L O G(C C N) \\
C C N / C C\end{array}$ \\
\hline $3 / 78$ & 7.0 & 40 & 1.9 & 306 \\
\hline $4 / 78$ & 8.5 & 39 & 1.6 & 266 \\
\hline $5 / 78$ & 12.8 & 44 & 1.5 & 215 \\
\hline $6 / 78$ & 18.8 & 41 & 2.6 & 214 \\
\hline $7 / 78$ & 21.3 & 43 & 1.4 & 270 \\
\hline
\end{tabular}




\section{TABLE 1D BNW-1 MONTHLY AVERAGES}

6

\begin{tabular}{|c|c|c|c|}
\hline DATE & $\begin{array}{c}\text { WIND } \\
\text { DIRECTION }\end{array}$ & $\begin{array}{c}\text { TEMPERATURE } \\
{ }^{C} \mathrm{C} \\
\end{array}$ & $\begin{array}{c}\text { OZONE } \\
\mathrm{ppb} \\
\end{array}$ \\
\hline $7 / 78$ & --- & 24.3 & 45 \\
\hline $8 / 78$ & -- & 24.0 & 41 \\
\hline $9 / 78$ & 229 & 17.2 & 34 \\
\hline $10 / 78$ & 250 & 10.8 & 34 \\
\hline $11 / 78$ & 231 & -3.5 & 36 \\
\hline $12 / 78$ & 257 & -5.4 & 36 \\
\hline
\end{tabular}




\section{TABLE 2}

\section{SULFUR DIOXIDE AIR QUALITY STANDARDS}

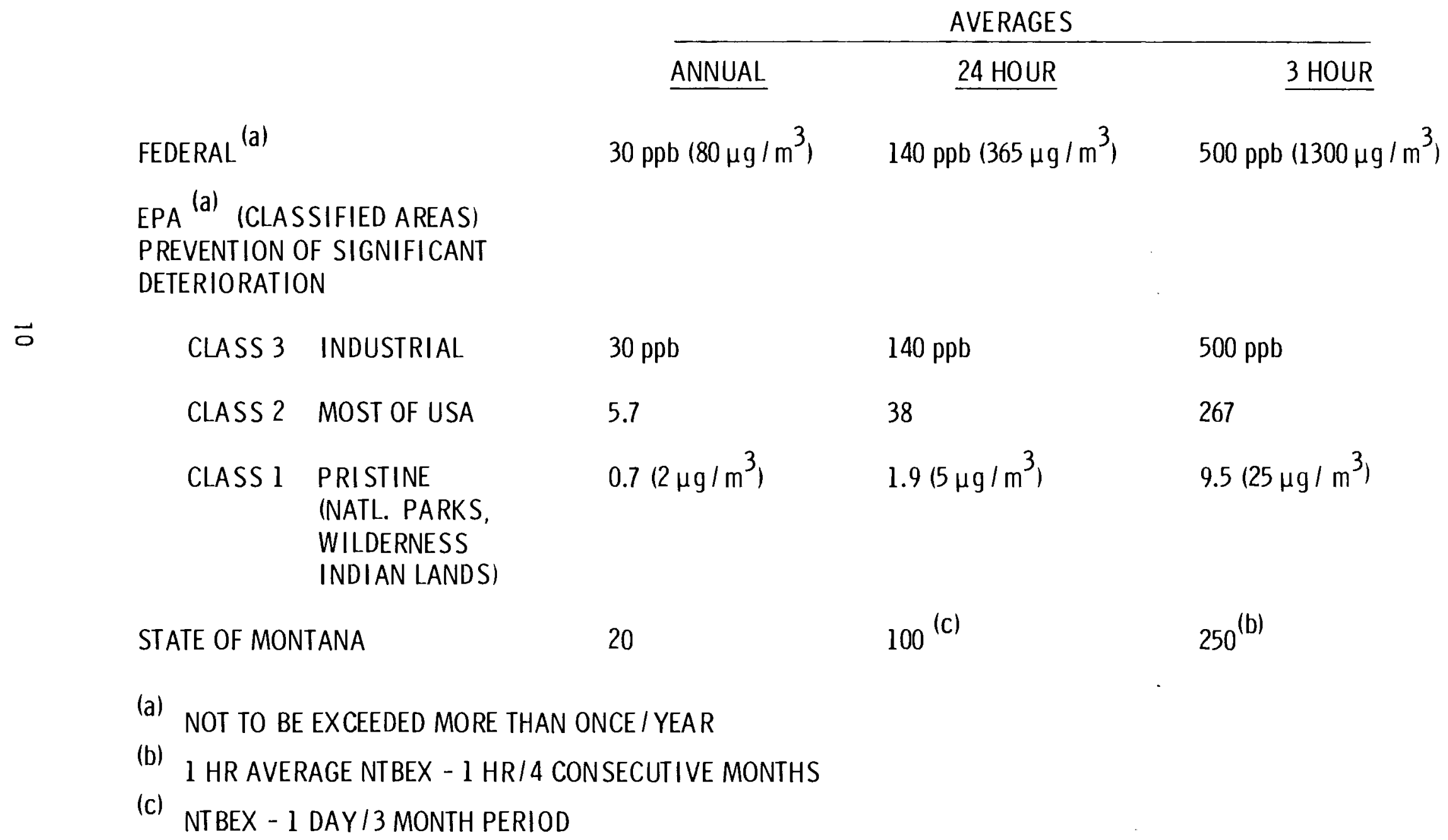


increase of $0.8 \mathrm{ppb}\left(1.9 \mu \mathrm{g} / \mathrm{m}^{3}\right)$ even though $\mathrm{KE}$ is several miles further downwind of the Colstrip area. A similar increase was observed at BNW-1, very close to Colstrip. A slightly larger increase of $1.15 \mathrm{ppb}\left(2.66 \mathrm{\mu g} / \mathrm{m}^{3}\right)$ was observed at Hay Coulee, downwind of the BNW-1 site. Although variations in operational periods exist, it appears that an overall elevation of 1 ppb of sulfur dioxide throughout the area were measured during 1978.

Evidence as to the source of the pollution comes from several areas throughout this report. Figure 2 illustrates the generally correlating character of the monthly sulfur dioxide fluctuations of the individual stations. This is indicative of a common pollution source influencing the area.

Monthly sulfur concentration comparisons were also made between individual sites and power plant output levels in an attempt to observe correlations. A summary of pertinent source information was published by the Montana Power Company and transmitted routinely to the State of Montana for overview purposes. This data and relevant calculations are included in Appendix $C$. The power plant influence at a particular site was normalized to the percent of time the winds were from the power plant direction. A sector, $\pm 30^{\circ}$ of the centerline direction, was chosen to represent the power plant winds. Figures $3 A$ and $3 B$ illustrate these results at $\mathrm{KW}$ and Hay Coulee. Although excellent correlations were observed for $\mathrm{KW}$, the direct influence of power plant sulfur dioxide was less obvious at Hay Coulee. Data presented later in this report indicate that both wind direction and stability play dominant roles in transporting the plume to the sites. It is thus apparent that an additional comparison of atmospheric stability would be necessary to properly assess the direct power plant/monitoring station correlations.

In addition to the longer, time-averaged values mentioned, many interesting features of the monitoring information are apparent in the real time data. Due to the remote rural location of the stations, most of the air being monitored contains little more than hemispheric concentrations of gaseous and particulate materials. When meteorological conditions prevait that are conducive to downward transport of the power plant plume to the stations, plume strikes are unmistakably prominent features upon this data base. Figure $4 A$ is a classical plume strike situation in which elevated levels of sulfur 
FIGURE 2

MONTHLY $\mathrm{SO}_{2}$ CORRELATIONS BETWEEN AIR MONITORING STATIONS

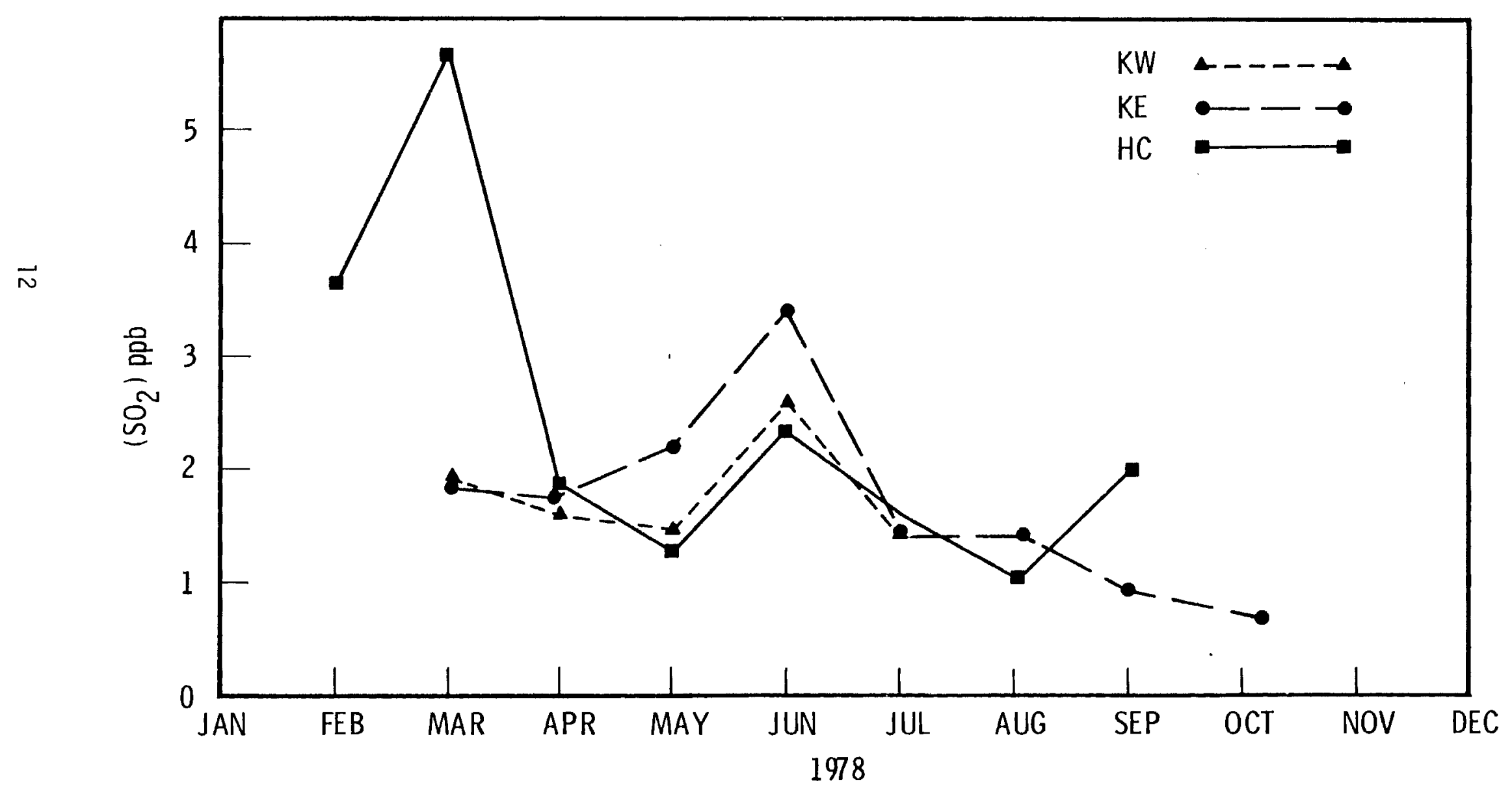




\section{FIGURE $3 A$}

\section{COMPARISON OF SOURCE TERM AND DOWNWIND MONITORING DATA}

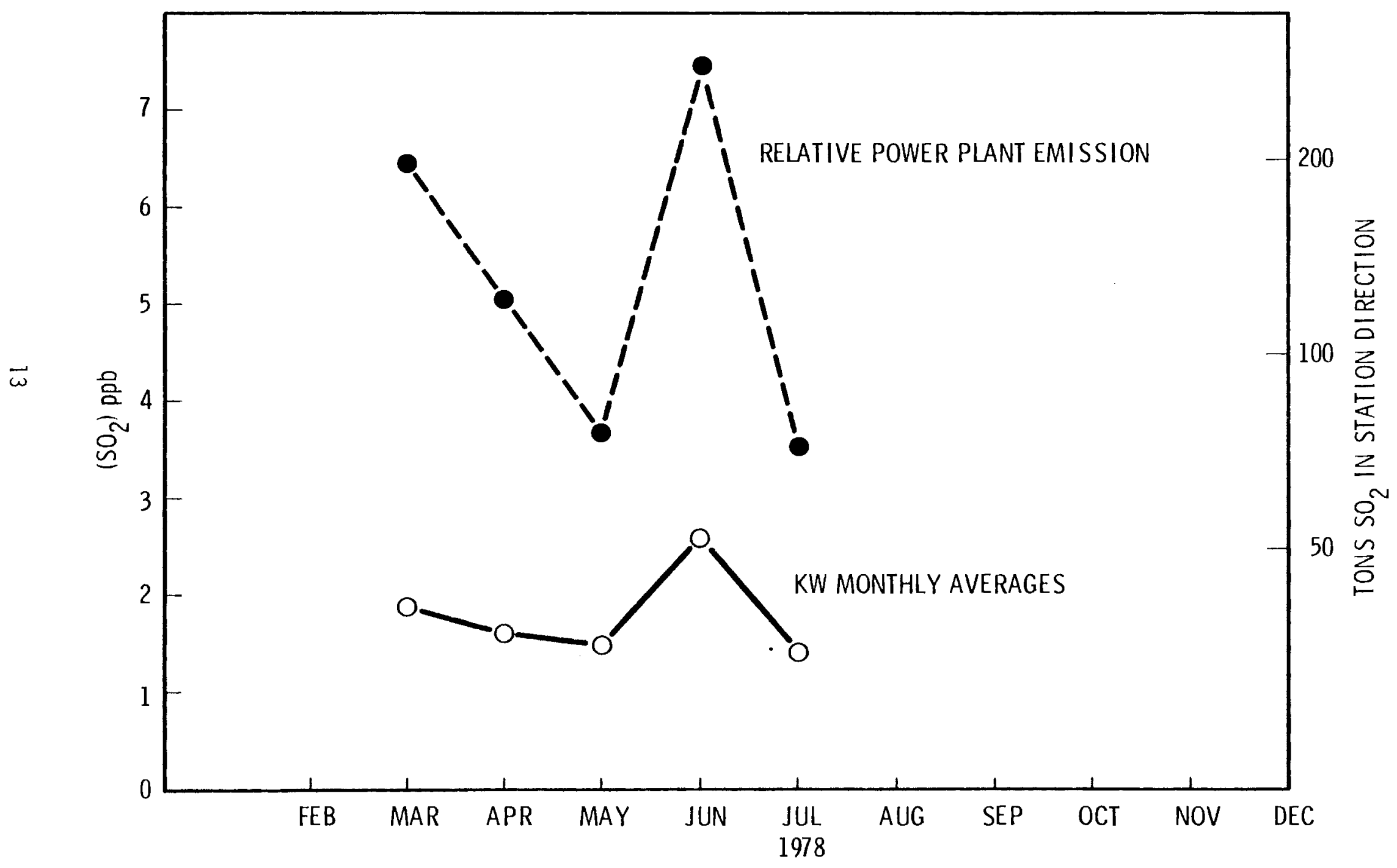


FIGURE 3B

COMPARISON OF SOURCE TERM AND DOWNWIND MONITORING DATA

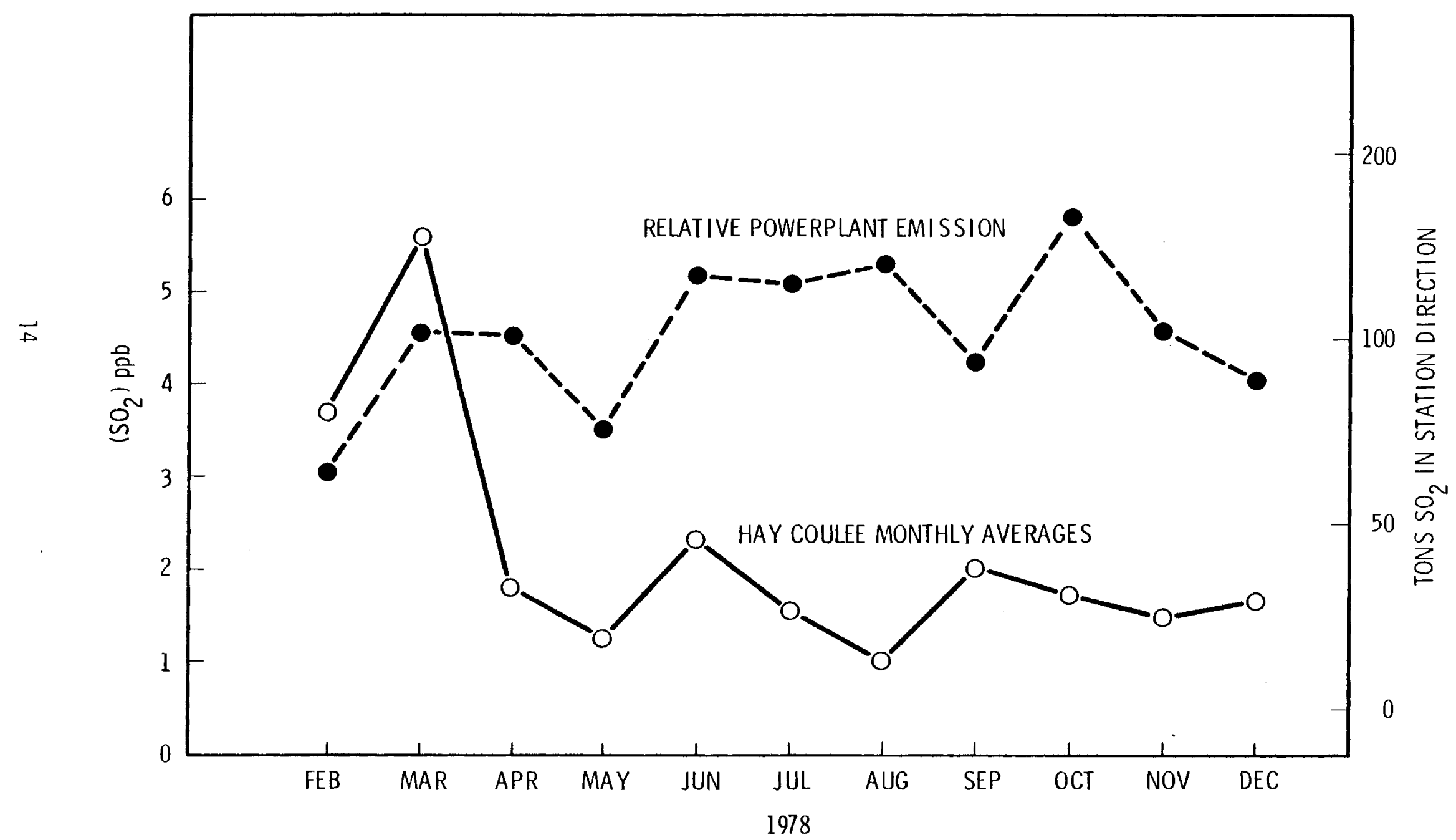


FIGURE 4A

\section{AIR MONITORING INFORMATION: TYPICAL PLUME STRIKE}

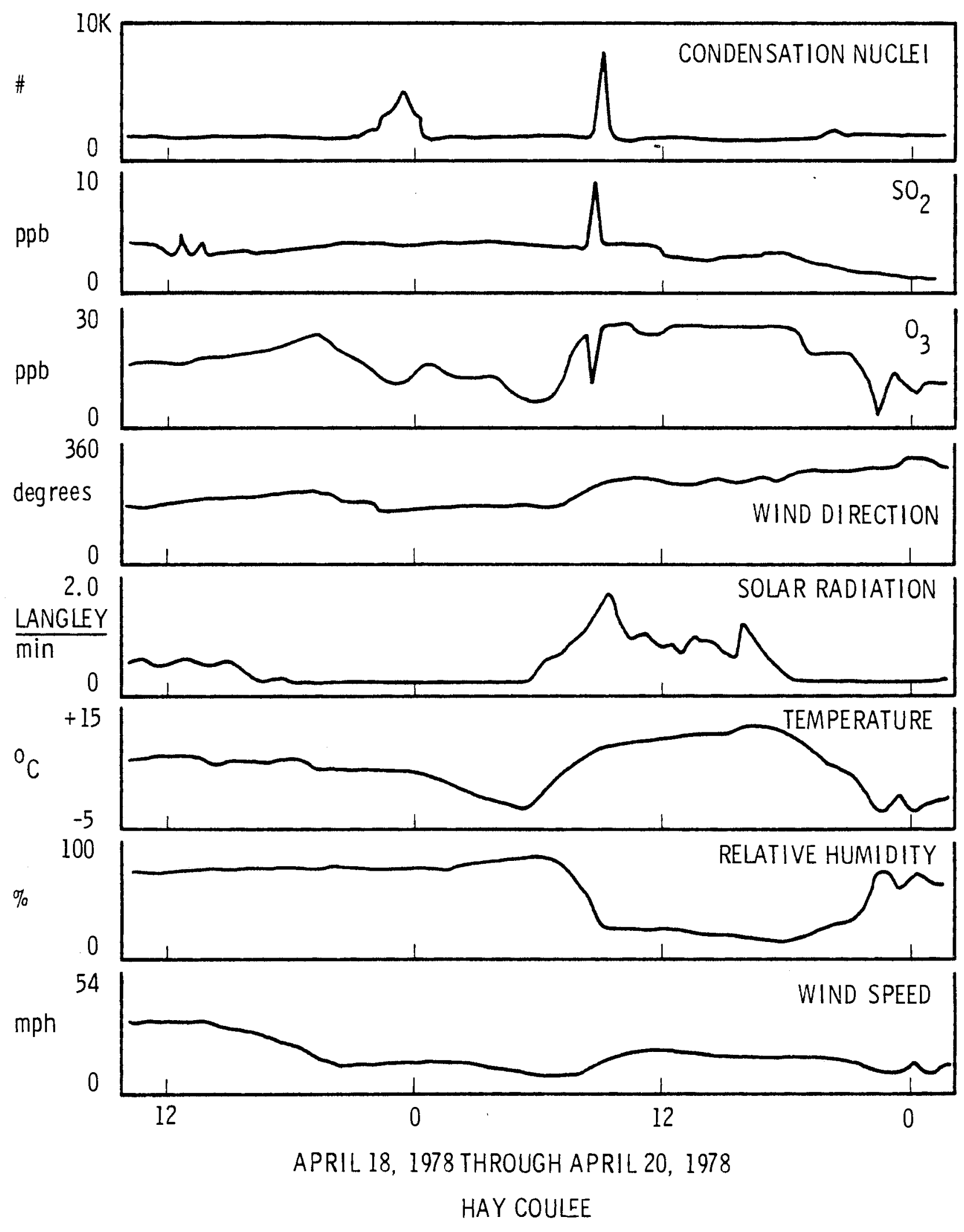


dioxide are correlated with particulates from the power plant stack when the wind vector orients from the plant direction. Excesses of nitric oxide in the plume from high-temperature coal burning processes are often apparent in the data as a result of their interaction with atmospheric ozone, as follows:

$$
\mathrm{O}_{3}+\mathrm{NO} \longrightarrow \mathrm{NO}_{2}+\mathrm{O}_{2}
$$

The anticorrelations between sulfur dioxide and ozone are further evidence of the presence of the power plant plume. Not all sulfur plume strikes bear such evidence, however. Sulfur dioxide excursions are occasionally accompanied by unchanged or increasing ozone concentrations. Masking of the ozone anticorrelation can take place in several ways. At first, while consuming ozone, No is converted to $\mathrm{NO}_{2}$ and adds to that already emitted. A second process, creating ozone, is known to become important during daytime hours as the concentration of $\mathrm{NO}_{2}$ increases: (11)

$$
\begin{aligned}
& \mathrm{NO}_{2} \stackrel{\mathrm{hv}}{\longrightarrow} \mathrm{NO}+\mathrm{O}^{\cdot} \\
& \mathrm{O}^{\cdot}+\mathrm{O}_{2} \longrightarrow \mathrm{O}_{3}
\end{aligned}
$$

Thus, the age of the pollutant plume may influence the net effect of NO and $\mathrm{NO}_{2}$ on the correlating ozone concentrations.

Elevated ozone concentrations have also been observed above stable underlying air masses. (12) Convective turbulence, which appears important in transferring the pollutant plume to the monitoring station may also, on occasion, be responsible for elevated ozone levels and interference with anticorrelations that were initially created by the pollution source.

A 2-day period is illustrated in Figure 48 in which three plume strikes were evident each time the wind cycled through the plant direction. It is apparent from the frequency of appearance of these conditions that plume strikes are rather common. Daytime convective turbulence as suggested by fluctuations in the solar data, appears often to mix the plume downward to the stations in spite of the elevated plume injection height and interfering terrain. Situations of direct transport of lower-level pollutants appear also to enter the data, as indicated by the nighttime strike shown in Figure $4 C$. 
FIGURE 4 B

\section{AIR MONITORING INFORMATION: MULTIPLE PLUME STRIKES}

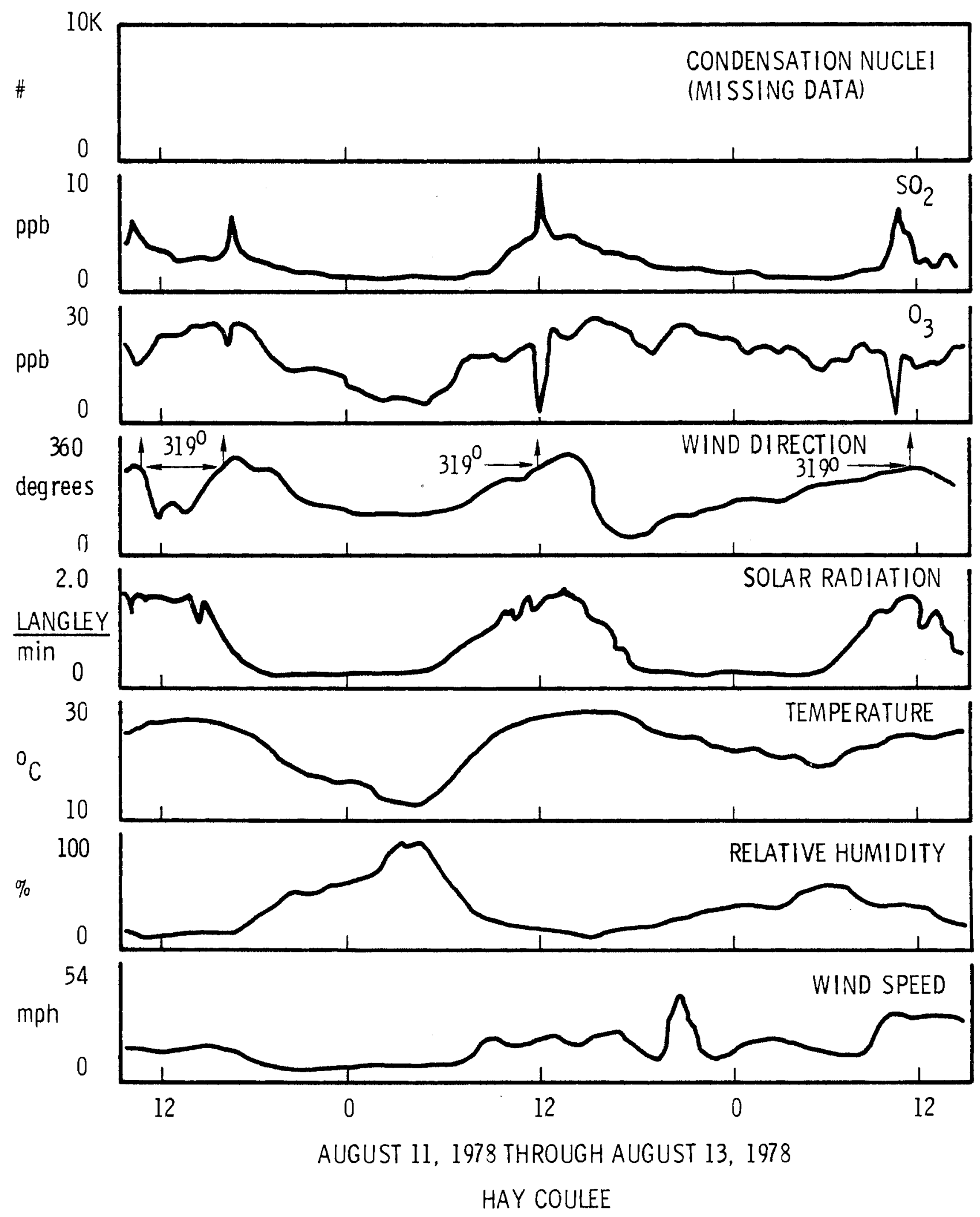




\section{FIGURE 4C}

\section{AIR MONITORING INFORMATION: NIGHTTIME PLUME STRIKE}
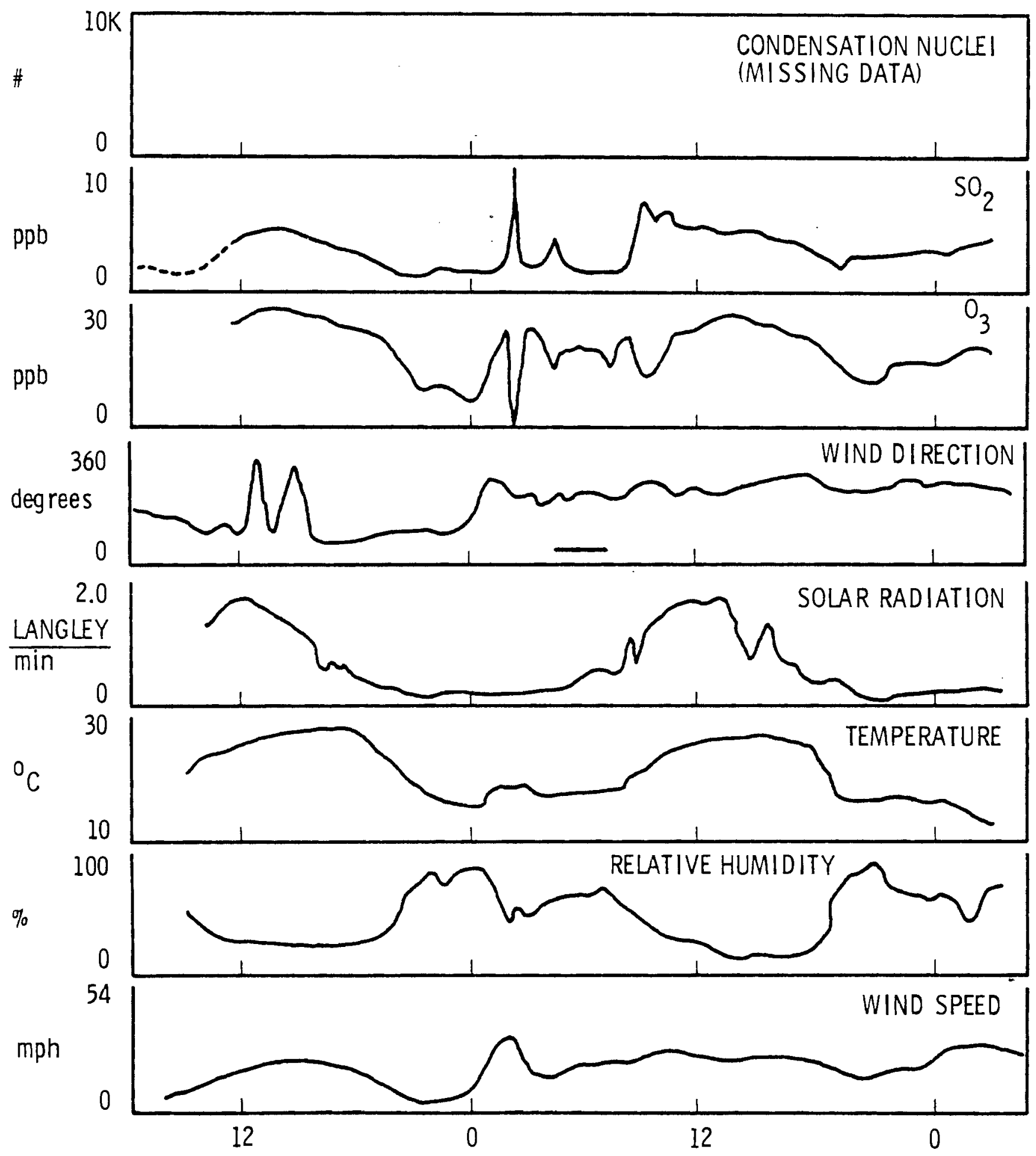

JULY 31, 1978 THROUGH AUGUST 2, 1978

HAY COULEE 
Important, interesting information was collected concerning the downwind pollution and the horizontal stretching of the power plant plumes. These data were derived from cases in which sulfur strikes occurred at two or more stations from the same plume in a time sequence appropriate for the prevailing meteorological situation. A typical example of such an event is illustrated in Figure 4D. The angular spacing of these stations (see figure 1) illustrates the horizontal dispersion of the plume as well as its downwind progress and dilution.

As field experience was gained concerning the probable location of plume intercepts, emphases were placed on relocating the monitoring stations for maximum effectiveness. The results of such reorientation are shown in Figure 5. Here, three co-linearly oriented stations (see Figure 1) exhibited the effects from the same power plant plume. It is also a representation of the topographical features southeastward from the Colstrip, Montana area. The low peaks to the east are slightly south of the exact station orientation. Although Class 1 land falls within the Greenleaf site distance, it does not approach this site in its actual geographic fluctuations. The maximum concentrations observed at each site are listed. This was one of two similar triple strike situations that took place in early November 1978. At that time, approximately $500 \mathrm{ppm}$ $\left(1150 \mathrm{mg} / \mathrm{m}^{3}\right)$ of sulfur dioxide were measured in the output from each of two power plant stacks. Thus, the concentration dilution for the first sample location two miles downwind was approximately $2.5 \times 10^{4}$.

Previous estimates of the frequency and intensity of plume fumigations at the more distant monitoring stations were negligible. This was not found to be the case. These estimates were derived from diffusion models which attempted modification of existing flat surface models to the mountainous terrain environment. A brief attempt was made, under the auspices of this program, to compare downwind exposure predictions from the diffusion modeis that are in present usage, with those actualiy observed at the sites. Experience with the EPA, PTMTP atmospheric model used for comparison purposes during high sulfur dioxide exposures in February and March indicated a considerable underestimation of the observed values. Use was made, therefore, of a computer modeling program at the University of Montana relied upon for downwind plume estimates (Williams, 1978) in this type terrain. Atmospheric stability data was incorporated into this model derived from tower instrumentation located beside the 
FIGURE 4D

\section{AIR MONITORING INFORMATION:MULTIPLE STATION PLUME STRIKE}

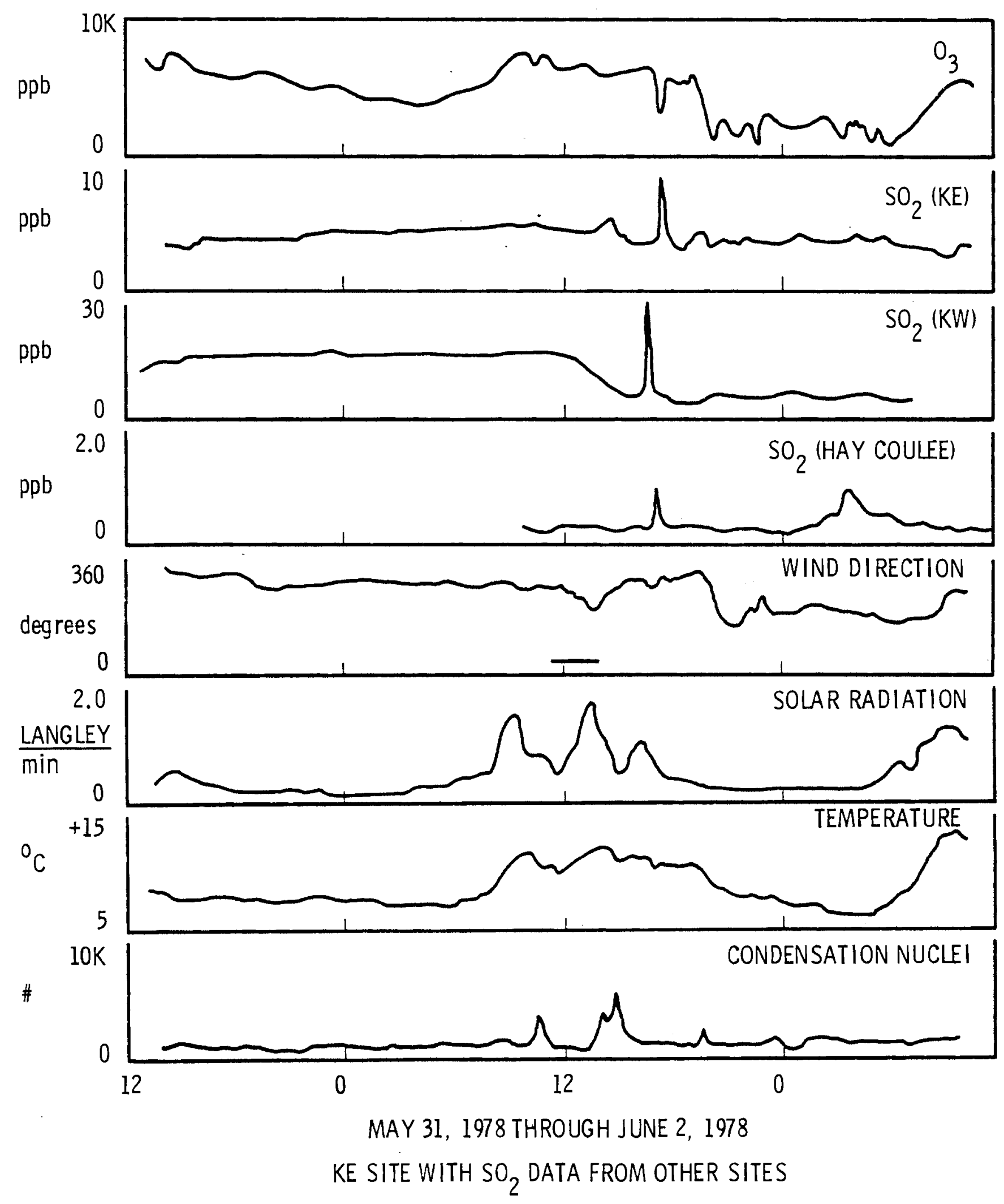


FIGURE 5

\section{SOUTHEAST TERRAIN CROSS SECTION FROM THE COLSTRIP POWER PLANTS}

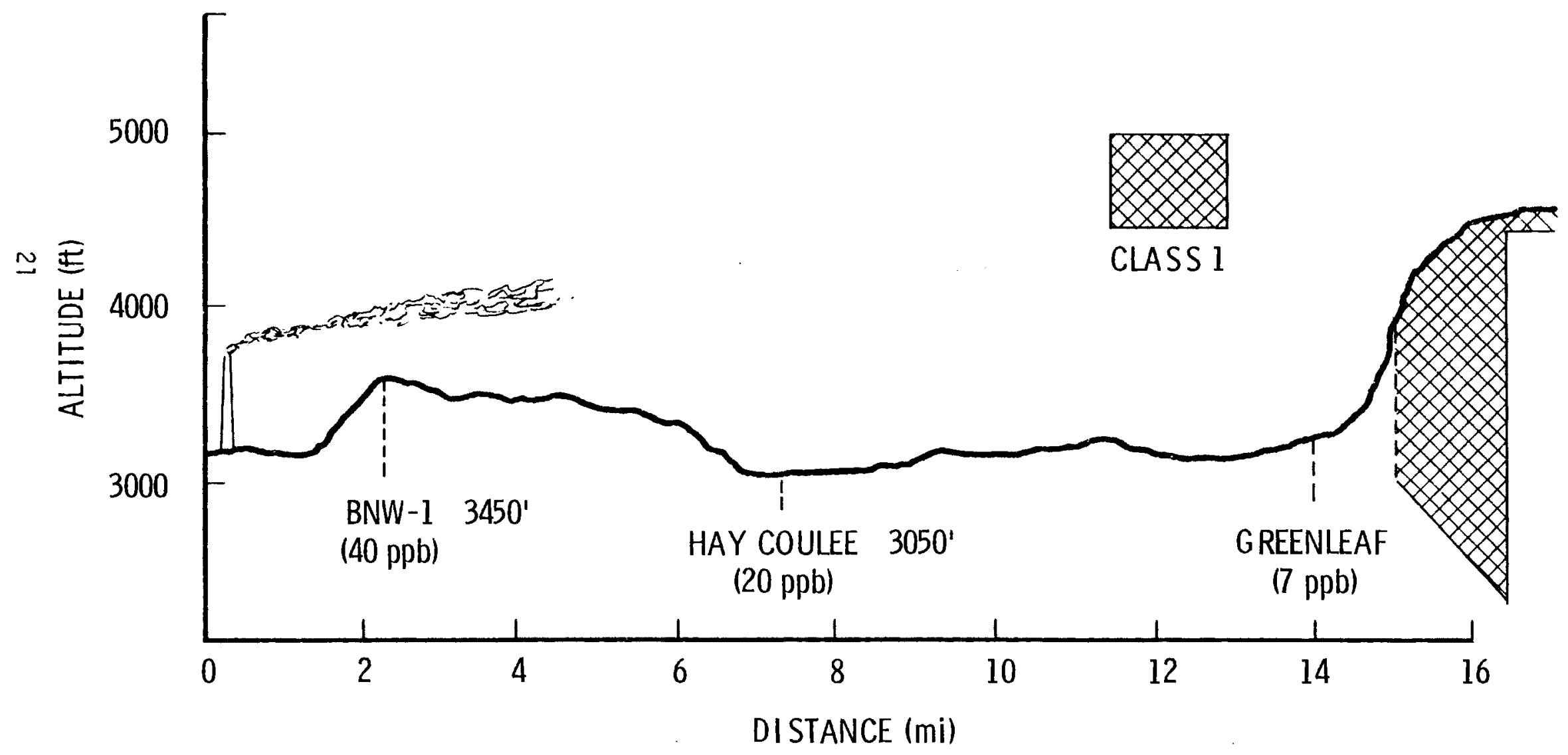


power plant stack. Comparisons between actual and predicted concentrations of sulfur dioxide at the sites in Figure 5 are shown on Table 3 . The model predictions were based upon maximum exposures from full power operation of the coal-fired plants. This was not the situation at this time; however, even these overestimates fall short of reality at the greater distances. Also evident in this case history is the variation of exposure with distance. A though the peak concentrations observed at the sites varied by a factor of 5 , the integrated exposures did not change significantly with downwind travel. This produced unexpectedly high exposures at longer distances. Meteorological situations that promote such occurrences are evidently more frequent than expected.

The 1978 data set was interrogated with respect to 3-hr and calendar day sulfur dioxide exposures. These limits were used to allow comparisons with the National Air Quality Standards (Table 2). No excesses were observed for the Class 2 category on which the sites were located. The total number of estimated excesses with respect to the nearby Class 1 land are shown in Table 4 along with other pertinent data. A specific compilation by date and time are inciuded in Appendix D. A significant number of these days are illustrated in the monitoring information. Individual plume strikes generally show chemical and physical correlations which are useful for source identification. The results of even this short-term averaging, however, obscure these effects on the atmospheric components ozone and particulates. The wind direction data is pertinent, however, and reflects the source direction from the particular monitoring station. Because of the close proximity of two sites (Greenleaf and $K E$ ) to the Class 1 area, their importance is enhanced.

In order to identify the location of probable sources of sulfur dioxide to each major monitoring station, the direction of incoming sulfur dioxide was correlated with its concentration isopleth. The entire year of data was utilized for this purpose in order to reflect all possible sources of sulfur dioxide. Figures $6 \mathrm{~A}, 6 \mathrm{~B}$, and $6 \mathrm{C}$ illustrate the results of these comparisons. Each display is a sulfur dioxide concentration isopleth on an annual basis for $10^{\circ}$ directional increments around the particular stations shown. Several features are common to these illustrations. Each has a major concentration lobe in the direction of the coal-fired power plants. All illustrate a rather 


\section{TABLE 3 DIFFUSION MODEL PREDICTIONS VS MEASURED HOURLY AVERAGED $\left(\mathrm{SO}_{2}\right)$}

\begin{tabular}{|c|c|c|c|c|}
\hline & TIME & BNW-1 & $\mathrm{HC}$ & GREENLEAF \\
\hline \multirow{4}{*}{ MODEL ${ }^{\dagger}$} & $9-1000$ & $0 \mathrm{ppb}$ & $0 \mathrm{ppb}$ & $0 \mathrm{ppb}$ \\
\hline & $10-1100$ & 1.1 & 0.2 & 2.7 \\
\hline & $11-1200$ & 0.1 & 0 & 0.1 \\
\hline & $12-1300$ & 22 & 10 & 0.5 \\
\hline
\end{tabular}

$$
\begin{array}{r}
\text { MEASURED * }\left\{\begin{array}{r}
9-1000 \\
10-1100 \\
11-1200 \\
12-1300
\end{array}\right. \\
+ \text { SEE (WILLIAMS, 1978) } \\
{ }^{*} \text { ALL VALUES } \pm 0.5 \mathrm{ppb}
\end{array}
$$$$
25
$$

5.0

3.0

3.0

6.0

4.5

3.0

4.5

5.0 


\section{TABLE 4 \\ FREQUENCY OCCURANCE OF ELEVATED SO2 EXPOSURES DURING 1978}

\begin{tabular}{|c|c|c|c|c|c|}
\hline SITE & $\begin{array}{c}\text { DISTANCE } \\
\text { FROM SOURCE }(\mathrm{km}) \\
\end{array}$ & $3 \mathrm{hr}$ AVE $\geq 10 \mathrm{ppb}$ & $24 \mathrm{hr}$ AVE $\geq 2 \mathrm{ppb}$ & $\begin{array}{c}\text { AVE } \mathrm{SO}_{2} \\
\text { (ppb) } \\
\end{array}$ & $\begin{array}{c}\text { OBSERVATION } \\
\text { PERIOD (mo) }\end{array}$ \\
\hline BNW-1 & 4.1 & 9 & 72 & 3.1 & 5.5 \\
\hline KLUVER WEST & 11.2 & 5 & 54 & 2.8 & 4.5 \\
\hline HAY COULEE & 11.6 & 18 & 161 & 3.2 & 10.8 \\
\hline KLUVER NORTH & 14.1 & 0 & 19 & 2.8 & 1.8 \\
\hline KLUVER EAST & 18.2 & 0 & 47 & 2.7 & 6.3 \\
\hline CLASS I LAND & 222 & - & $12^{a)}$ & - & $12^{\text {a) }}$ \\
\hline GREENLEAF & 225 & 0 & 1 & 1.9 & 1.0 \\
\hline
\end{tabular}


FIGURE 6A

TIME AVERAGED $\mathrm{SO}_{2}$ CONCENTRATION ISOPLETH FOR $10^{\circ}$ INCREMENTS AROUND HAY COULEE FOR 1978

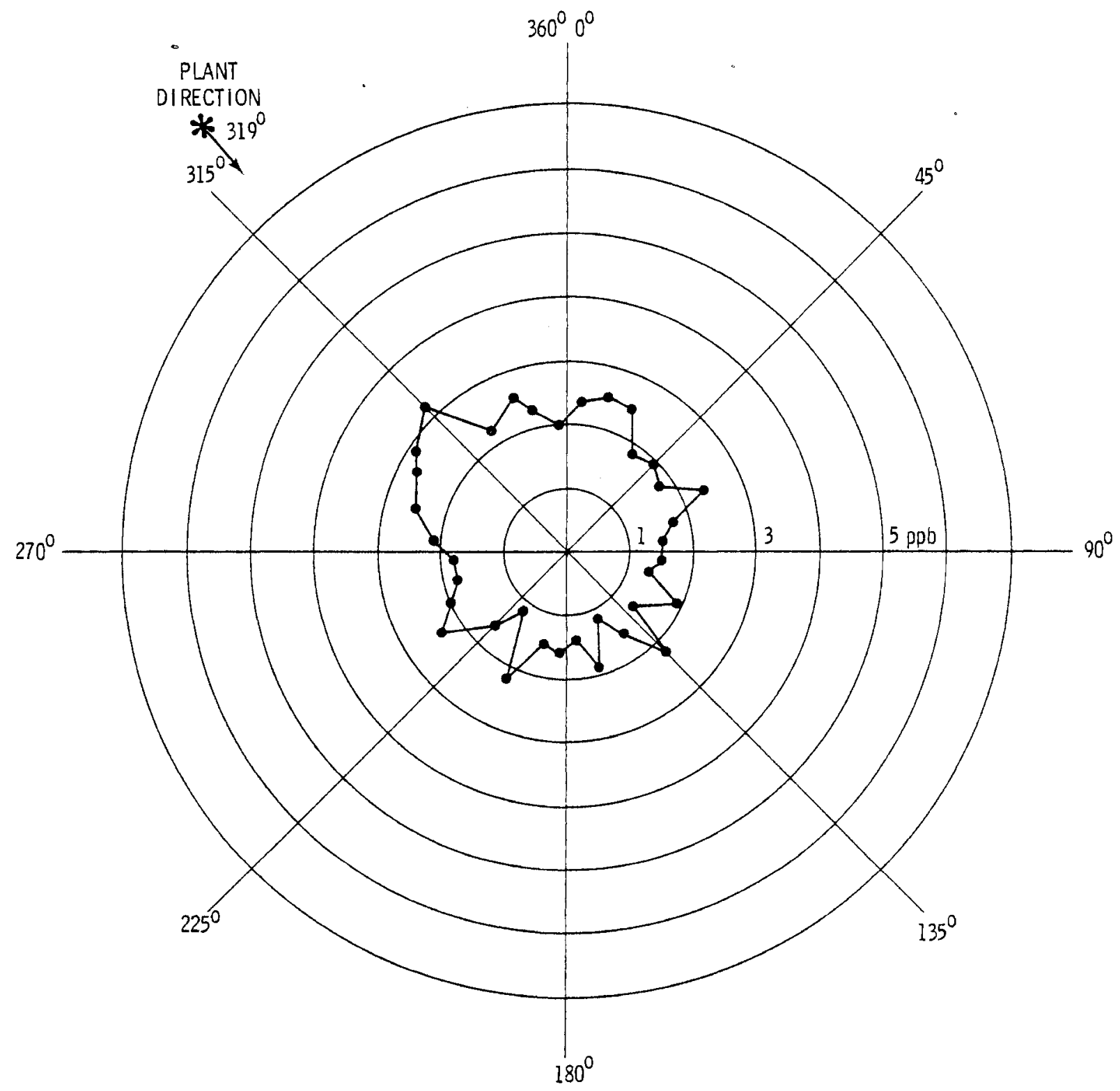


FIGURE 6B

TIME AVERAGED $\mathrm{SO}_{2}$ CONCENTRATION ISOPLETH FOR $10^{\circ}$ INCREMENTS AROUND KE FOR 1978

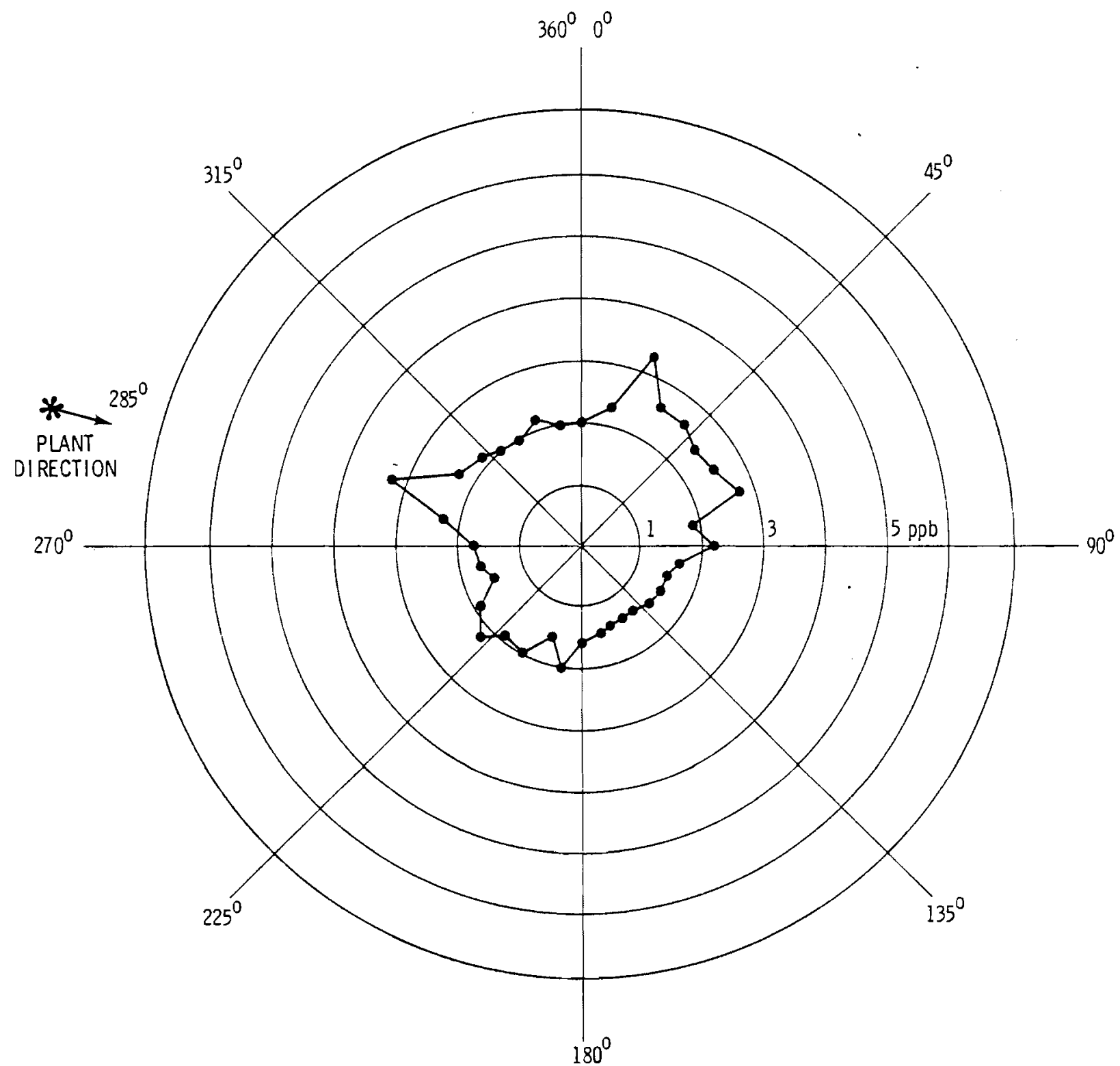


FIGURE 6C

TIME AVERAGED $\mathrm{SO}_{2}$ CONCENTRATION ISOPLETH FOR $10^{\circ}$ INCREMENTS AROUND KW FOR 1978

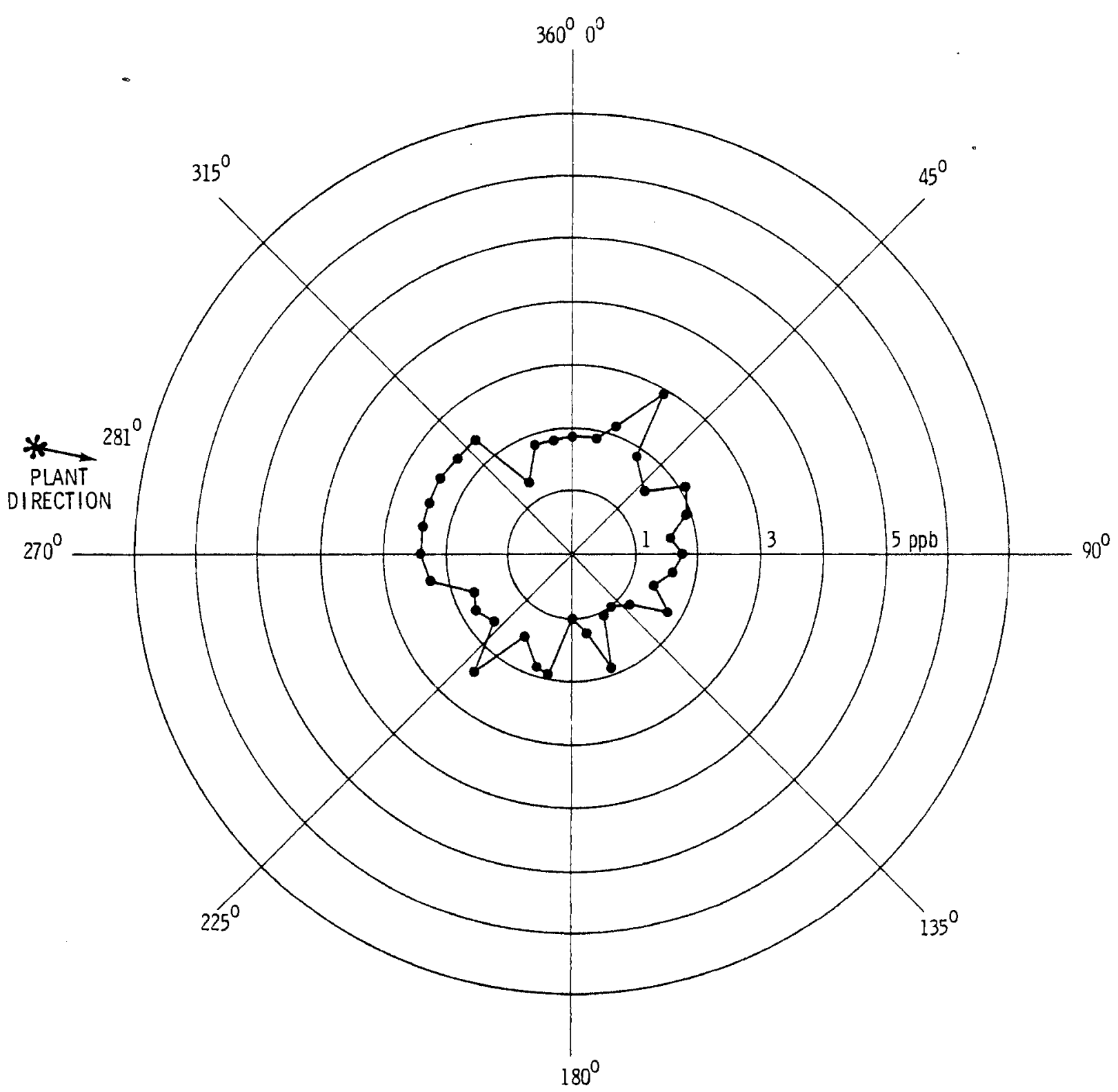


low sulfur dioxide input from southeasterly winds opposed to the power plant's direction. A lesser source term seems apparent to the northeast between $15^{\circ}$ and $30^{\circ}$ true north with respect to each station. A comparison of the topographical features of the area with this secondary source was helpful. It appears that the apparent direction of this secondary source correlates with the contours of Rosebud Creek. Evidently the common westerly winds fumigate the area to the north of our sites. Then sulfur dioxide becomes trapped in the lower terrain and northerly winds create flow through the valley bringing elevated concentrations of sulfur dioxide to the stations.

As the plant plume moves eastward over the station network, it will from time to time, as shown earlier, mix downward to ground level. The frequency of this occurrence as well as the magnitude of such events relate to the instantaneous and integrated exposures observed from the emitted pollutants. Table 5 illustrates the integrated hourly sulfur dioxide exposure frequency observed at the sites. This data is presented in a manner comparable with other field studies. $(13,14)$ These studies suggest that the product of the sulfur dioxide concentration and exposure time is correlated with the damage expected from such fumigations. A summary of the 1978 data is. shown in Table 6 including the number of hours of valid data. The period of operation varied considerably from site to site as instrumentation was utilized in what appeared to be the most expeditious manner at the time. Data omission also occurred because of power failures, instrument breakdowns and data editing.

As expected, the frequency of elevated exposures to sulfur dioxide decreases with distance from the power plants; however, the particular site location could serve to obscure this effect. For example, although BNW-1 is close to the source, the plume may be injected into the atmosphere at an altitude above the site. This does not preclude downwind mixing processes that do, on occasion, bring the plume down to more distant stations.

During the term of this project some emphasis was placed on reporting plume strike activity at the stations as quickly as possible. This allowed immediate comparisons of power plant activity, and meteorological situations. For this purpose, backup capability was provided by strip chart recorders. The recorder charts can be utilized to improve the continuity of data collection; however, the computer-compatible datalogging system proved to have a 
TABLE 5

FREQUENCY DISTRIBUTION OF $\mathrm{SO}_{2}$ EXPOSURES IN THE AIR MONITORING NETWORK

HOURLY AVERAGED

$\mathrm{SO}_{2}(\mathrm{ppb})$

$* 0$

1

3

4

5

6

7

8

9
10

11

12

13

14

15

16

17

18

19

20

21

22

23

24

25

26

27

28

50

NUMBER OF TIMES AIR CONCENTRATION EXCEEDED OR EQUALED

$$
\text { HAY COULEE . }
$$

4638

3035

2408

1625

944

577

320

194

125

90

43

28

19

15

12

9

7

6

1

0

0

0

0

0

0

0

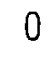

0

0

KE $\quad K W$

1987

1319

1006

660

368

180

57

23

11
$\frac{K W}{1926}$

1339

1040

676

274

103

39

22

15

11

5

5

4

2

1

1

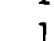

1$$
1
$$

0

0

0

0

0

0

0

0

0

0

\begin{tabular}{|c|c|c|}
\hline KN & BNW-1 & GREENLEAF \\
\hline 821 & 304 & 334 \\
\hline 386 & 1732 & 80 \\
\hline
\end{tabular}

297

196

123

59

21

7

1

0

0

0

0
0

0

0

0

0

0

0

0

0

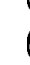

0

0

0

0

?

* VALID dATA COLLECTION TIMES 


\section{TABLE 6 \\ AIR MONITORING DATA AVERAGES FOR 1978 a)}

\begin{tabular}{|c|c|c|c|c|c|c|}
\hline & HAY COULEE & $\mathrm{KE}$ & $\mathrm{KW}$ & $\mathrm{KN}$ & BNW-1 & GREENLEAF \\
\hline $\mathrm{SO}_{2} \quad(\mathrm{ppb})$ & 2.04 & 1.83 & 1.84 & 1.3 & 1.73 & 0.47 \\
\hline $\mathrm{O}_{3} \quad(\mathrm{ppb})$ & 36.8 & 39.1 & 40.7 & 34.4 & 36.6 & 32.1 \\
\hline LOG NUCLEI (\#) & 2.92 & 2.92 & 2.49 & -- & 2.99 & --- \\
\hline WIND ()$\left.^{0}\right)$ & 307 & 201 & 279 & 224 & 281 & --- \\
\hline WIND $(\mathrm{km} / \mathrm{hr})$ & 9.1 & -- & --- & --- & 31 & --- \\
\hline TEMPERATURE $\left({ }^{0} \mathrm{C}\right)$ & 6.9 & 14.8 & 13.3 & -7.9 & 9.9 & --- \\
\hline HUMIDITY (\% RH) & 57 & -- & -- & -- & -- & -- \\
\hline RAD (LANGLFY/min) & 0.23 & 0.25 & 0.25 & 0.19 & --- & -- \\
\hline $\begin{array}{l}\text { TOTAL RECORDED } \\
\text { HOURS } \mathrm{SO}_{2}\end{array}$ & 4638 & 1987 & 1926 & 821 & 3041 & 334 \\
\hline $\begin{array}{l}\text { a) MANY AVERAGES } \\
\text { IN STATION OPER } \\
\text { PERIODS. }\end{array}$ & $\begin{array}{l}\text { REFECT ONL } \\
\text { RATION. SEE }\end{array}$ & EASS & VA & $\mathrm{BEC}$ & $\begin{array}{l}\text { OF VA } \\
\text { ERATI }\end{array}$ & $\begin{array}{l}\text { ATIONS } \\
\text { AL }\end{array}$ \\
\hline
\end{tabular}


high service reliability. Some of the sulfur dioxide plume strike correlations between sites that were observed in the overall data set are evident in the chart data. Appendix $E$ is a compilation of these sulfur dioxide fumigation periods and includes other available data from the sites at that time. Data flags are included during time periods in which more than one station recorded elevated sulfur dioxide by the same pollutant plume.

\subsection{AEROSOL SAMPLING DATA}

An aerosol sampling program was conducted at three of the sites in conjunction with the air monitoring. Samples were collected at intervals of a day or longer depending upon weather and personnel availability. The sampling system consisted of a cyclone separator with special orifice and pump. Figure 7 illustrates the separator, flowmeter and connections to a 4 CFM pumping system. The systems were matched to provide an aerosol separation at slightly less than one micron. Figure 8 illustrates the calibration curves obtained using standardized aerosols. Two fractions were collected from each sample with the fine portion accumulating on Whatman $41 \mathrm{filter}$ paper. The larger fraction was centrifugally maintained in a stainless cup of the separator. A procedure was developed for slurring this fraction and transferring it onto a polypropylene film. Then both fractions underwent $x$-ray fluorescence analys is for a series of trace elements. Thin film standards were routinely utilized in each batch analyzed by this technique.

Results from analys is of January 1978 samples during the rather clean aerosol period [snow on the ground and sulfur dioxide levels below $2 \mathrm{ppb}$ $\left.\left(4.6 \mu \mathrm{g} / \mathrm{m}^{3}\right)\right]$ are shown in Table 7 . The trace element concentrations of individual samples are below the detection limit of the analytical procedure for certain elements during such clean air periods. Consequently, the ratio between large and fine fractions have high uncertainties.

The entire 1978 data set was interrogated with respect to the appearance of high level sulfur dioxide concentrations. These are called plume "strike days" and are defined as those in which the hourly averaged sulfur dioxide concentrations exceeded $10 \mathrm{ppb}\left(23 \mu \mathrm{g} / \mathrm{m}^{3}\right)$. It was also noted that this 


\section{FIGURE 7 \\ AEROSOL PARTICLE SEPARATOR}

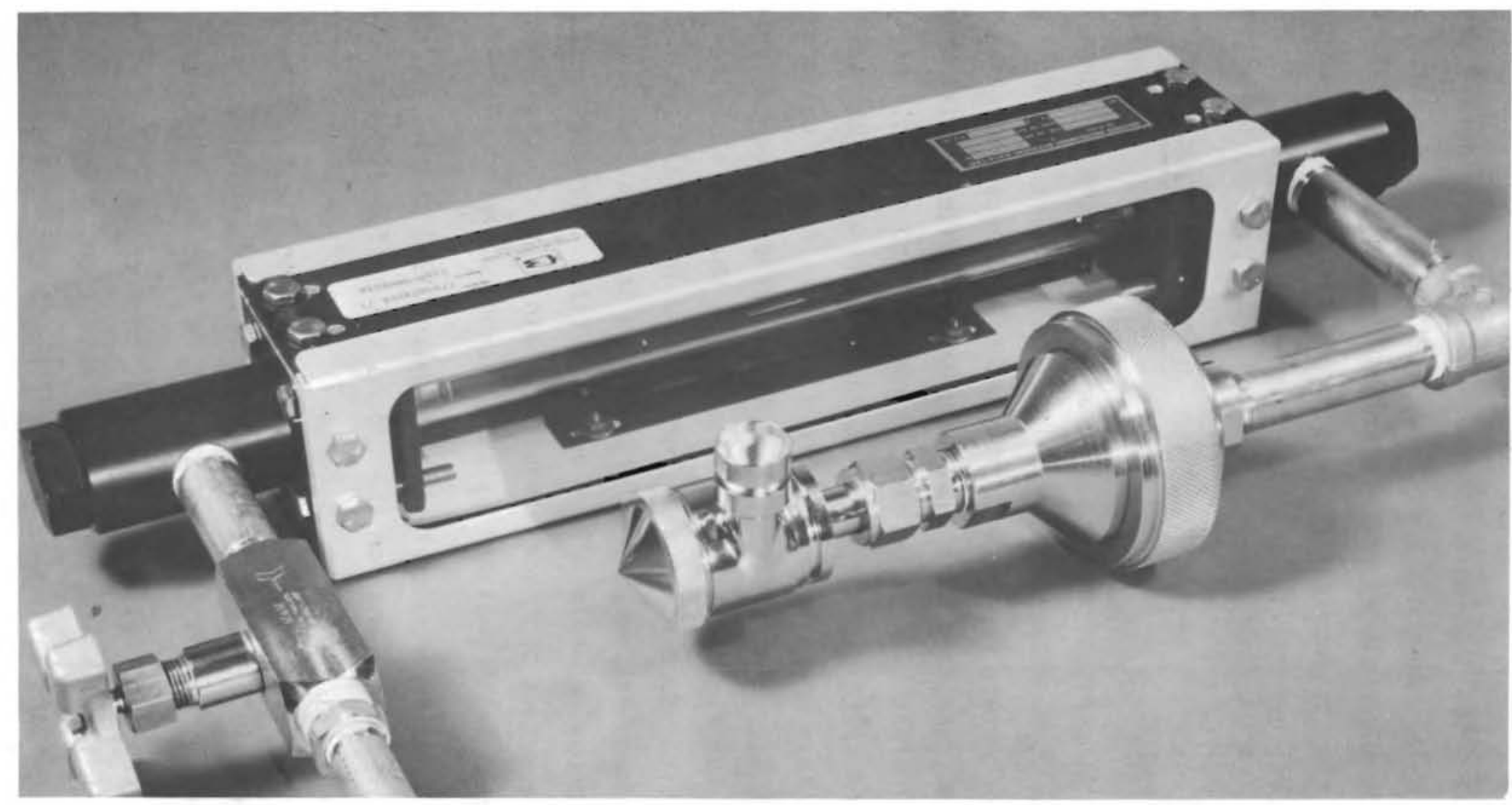


FIGURE 8

CYCLONE SEPARATOR DISTRIBUTION

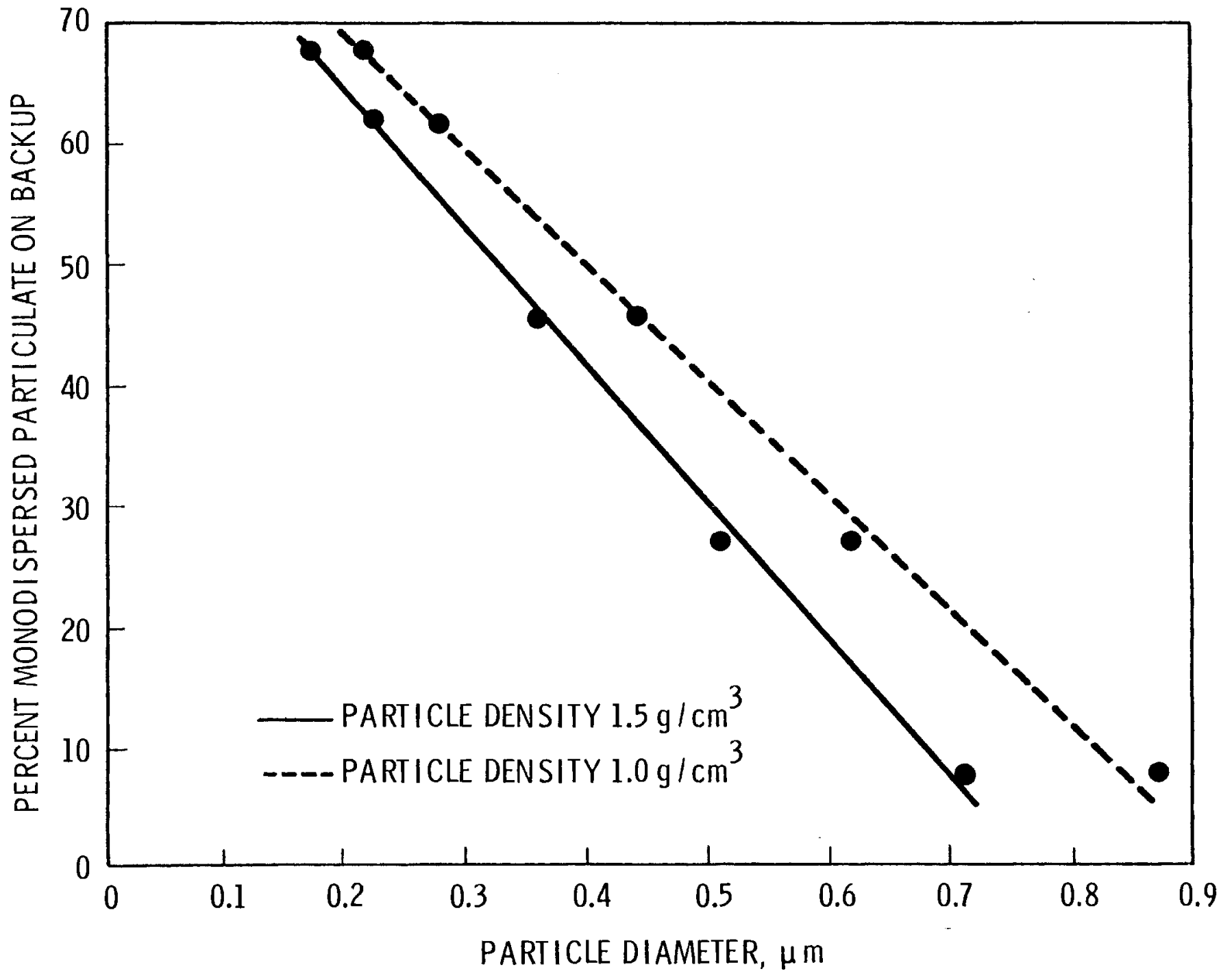




\section{TABLE 7}

\section{JAN. 1978 COLSTRIP AEROSOL CONCENTRATIONS $\mathrm{ng} / \mathrm{m}^{*}$}

\begin{tabular}{|c|c|c|c|c|c|c|c|c|c|c|c|c|c|}
\hline \multicolumn{2}{|c|}{ CI } & \multicolumn{2}{|c|}{ K } & \multicolumn{2}{|c|}{$\mathrm{Ca}$} & \multicolumn{2}{|c|}{$\mathrm{Ti}$} & \multicolumn{2}{|c|}{$\mathbf{V}$} & \multicolumn{2}{|c|}{$\mathrm{Mn}$} & \multicolumn{2}{|c|}{$\mathrm{Fe}$} \\
\hline$L$ & $\mathrm{~F}$ & $\underline{L}$ & $\mathrm{~F}$ & $L$ & $F$ & $L$ & $\mathrm{~F}$ & $L$ & $F$ & $L$ & $F$ & $L$ & $F$ \\
\hline 0.3 & 30 & 2.2 & 15 & 1.2 & 2 & 0.3 & 0 & 0 & 0 & 0.06 & 0 & 2. & 5 \\
\hline 0 & 0 & 2.9 & 17 & 2.7 & 9 & 0 & 0 & 0 & 0 & 0.1 & 1.5 & 3. & 17 \\
\hline 0 & 45 & 1.6 & 5 & 0.5 & 6 & 3.5 & 0 & 0.2 & 0 & 0.05 & 1.6 & 1. & 13 \\
\hline 0.4 & 0 & 1.4 & 21 & 0.5 & 0 & 0 & 0 & 0 & 3.3 & 0.05 & 1.7 & 2 & 9 \\
\hline 0 & 117 & 1.5 & 6.8 & 2.3 & 0 & 0.4 & 0 & 0 & 0 & 0.1 & 0.2 & 3. & 11 \\
\hline 0.3 & 0 & 3.7 & 6 & 2.0 & 4 & 0.7 & 0 & 0 & 0 & 0 & 0.2 & 3. & 8 \\
\hline 0 & 0 & 0.2 & 6 & 0.2 & 0 & 1.3 & 0 & 0 & 0 & 0.04 & 1.4 & 1. & 7 \\
\hline 0.14 & 27 & 1.93 & 12 & 1.34 & 4.4 & 0.9 & 0 & 0.03 & 0.84 & 0.05 & 1.2 & 2. & 10 \\
\hline
\end{tabular}

\begin{tabular}{|c|c|c|c|c|c|c|c|c|c|c|c|c|c|}
\hline \multicolumn{2}{|c|}{$\mathrm{Cr}$} & \multicolumn{2}{|c|}{ Co } & \multicolumn{2}{|c|}{$\mathrm{Ni}$} & \multicolumn{2}{|c|}{$\mathrm{Cu}$} & \multicolumn{2}{|c|}{$2 n$} & \multicolumn{2}{|c|}{$\mathrm{Pb}$} & \multicolumn{2}{|c|}{$\mathrm{Br}$} \\
\hline $\mathrm{L}$ & $\mathrm{F}$ & $\mathrm{L}$ & $F$ & $\mathrm{~L}$ & $F$ & $L$ & $\underline{F}$ & $L$ & $\mathrm{~F}$ & $\mathrm{~L}$ & $\mathrm{~F}$ & 1 & $F$ \\
\hline 0.1 & 1.5 & 0 & 0 & 1.3 & 2.2 & 1.4 & 4 & 0.05 & 0.2 & 0.04 & 3.3 & 0.03 & 0.3 \\
\hline 0.1 & 2.7 & 0 & 0 & 4.8 & 25 & 0.5 & 4 & 0.3 & 2 & 0.2 & 1.7 & 0.01 & 1.0 \\
\hline 0.04 & 3.6 & 0 & 0 & 0.5 & 34 & 0.4 & 3.4 & 0.2 & 1.4 & 0.1 & 1.7 & 0 & 1.6 \\
\hline 0.03 & 1.7 & 0 & 0 & 0.2 & 6 & 0.4 & 4.4 & 0.2 & 2.7 & 0.1 & 2.1 & 0.01 & 1.5 \\
\hline 0.05 & 1.6 & 0 & 2.4 & 5.8 & 4.8 & 0.2 & 3.4 & 0.2 & 2 & 0.2 & 5.6 & 0.02 & 1.6 \\
\hline 0.03 & 0.2 & 0 & 0 & 3.8 & 23 & 0.7 & 3.3 & 1.8 & 3.5 & 0.2 & 2 & 0.03 & 1.2 \\
\hline 0.05 & 0.2 & 0 & 0 & 0.5 & 23 & 0.1 & 2.8 & 0.01 & 0.3 & 0.03 & 4.3 & 0.01 & 0.3 \\
\hline 0.06 & 1.9 & 0 & 0.34 & 2.4 & 20 & 0.53 & 3.8 & 0.39 & 1.9 & 0.12 & 3.4 & 0.02 & 1.2 \\
\hline
\end{tabular}

\footnotetext{
${ }^{*} L=$ GREATER THAN $1 \mu \quad F=$ LESS THAN $1 \mu$
} 
situation occurred only when the wind direction was from the power plants. A second set of background days or "non-strike days" were also derived from the data. These were days in which the winds blew from the power plant quadrant but the sulfur dioxide levels were less than $2 \mathrm{ppb}\left(4.6 \mu \mathrm{g} / \mathrm{m}^{3}\right)$. The situation was prevalent when the plume failed to mix downward.

By comparing the elemental distributions of samples collected during these two periods, one can look for changes in the Colstrip natural aerosol levels with the addition of the power plant plume. Table 8 illustrates results of this comparison and includes background and source term information taken from earlier measurements in the Colstrip area. These data are shown in Appendix $D$ and include results of studies prior to power plant operation.

The ratios on the table were derived by first normalizing each element to the amount of iron found in the sample in question and then dividing that number by the elemental ratio observed in normal crustal material. The stack column illustrates the relative potency of the power plant emissions to change the natural aerosol distribution. The Colstrip aerosol column illustrates the aerosol differences that already exist between eastern Montana and average crustal distributions of elements. It appears that the selenium ratios had been modified in the aerosol by the stack; however, definitive explanations of other elemental changes are not as evident. The elevated lead and bromine values reflect the influence of Colstrip traffic upon the aerosols since the stack is incapable of modifying the ratios to the extent shown. The effects of mining operations in the plant direction versus those in other directions would also leave their imprint upon the particulate data although no such directional correlation was observed. In most situations, contributions to the aerosol come from several sources including the natural crustal materials and exact definition is complex. Significant elemental enrichment of the aerosol versus local soil were found for arsenic (26x) and $\mathrm{Zn}(3.5 \mathrm{x})$ in background measurements of the Colstrip area prior to power plant startup.

Utilizing the definition of strike and non-strike days given previously, Table 9 illustrates the ratios found between the fine and coarse particulate for each element in the aerosols. Those elements usually associated with crustal materials appear equally distributed between fractions. Elements 


\section{TABLE 8 ELEMENTAL DISTRIBUTIONS IN COLSTRIP AREA AEROSOLS}

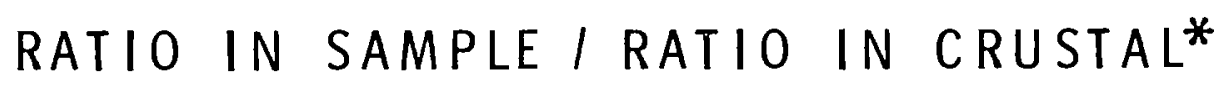

\begin{tabular}{|c|c|c|c|c|c|}
\hline ELEMENT & NON STRIKE DAYS & STACK & STRIKE DAYS & HI-VOL COLSTRIP & COLSTRIP SOIL \\
\hline $\mathrm{Ca}$ & 1.3 & 26 & 1.8 & 1.0 & 1.4 \\
\hline $\mathrm{Ti}$ & 1.0 & 8 & 1.3 & 0.66 & 1.4 \\
\hline $\mathrm{Mn}$ & 0.80 & 4.8 & 1.1 & 1.2 & 1.0 \\
\hline $\mathrm{Fe}$ & 1 & 1 & 1 & 1 & 1 \\
\hline $\mathrm{Cu}$ & 119 & 11 & 896 & - & - \\
\hline $\mathrm{Zn}$ & 19 & 7 & 97 & 3.3 & 3.4 \\
\hline Se & 983 & 26,000 & 10,000 & 1.1 & 600 \\
\hline $\mathrm{Pb}$ & 68 & 68 & 450 & - & - \\
\hline As & 90 & 350 & 825 & 26 & 9.3 \\
\hline $\mathrm{k}$ & 1.1 & 0.1 & 1.6 & - & 1.7 \\
\hline $\mathrm{Br}$ & 128 & 244 & 990 & - & 3 \\
\hline
\end{tabular}

* All VAlues were nORMALIZED tO Fe 


\section{TABLE 9}

\section{AEROSOL SIZE DISTRIBUTIONS IN $\mathrm{SO}_{2}$ POLLUTED AIR ON STRIKE DAYS}

RATIO OF FINE I COARSE $(\langle 1 \mu|>1 \mu)$

$\begin{array}{lrll}\mathrm{Ni} & 8 \pm 6 & \mathrm{Tl} & 0.13 \pm 0.10 \\ \mathrm{Cr} & 9 \pm 5 & \mathrm{Ca} & 0.86 \pm 0.66 \\ \mathrm{As} & 17 \pm 6 & \mathrm{Mn} & 0.69 \pm 0.31 \\ \mathrm{Zn} & 20 \pm 4 & \mathrm{~K} & 0.68 \pm 0.21 \\ \mathrm{~Pb} & 23 \pm 14 & \mathrm{Fe} & 1.3 \pm 1.1 \\ \mathrm{Se} & 28 \pm 31 & & \\ \mathrm{Br} & 136 \pm 81 & & \end{array}$


whose volatility or ability to fractionate to smaller particulate are found on the smaller fraction. It is informative to realize that strike days are associated with persistent rather than light and variable winds from the power plant direction. This would contribute to the increased course burden of crustal type material in the aerosol and, therefore, reduced particulate ratios.

\subsection{SUMMARY}

The pristine environment of Montana State lent itself to identifying, in part, the downwind impact from operation of the first major coal-fired power plants in that region. The complexity of contributing sources in the industrialized areas make specific plant impact relationships difficult to assess. For example, results from a monitoring program of similar orientation around two much larger power plants (3000 MW) indicate that their combined effect represents only a $10 \%$ sulfur dioxide increase in the seasonal backgrcund levels, (4) whereas, our study showed that winds from the power plant bring greater than twice the $\mathrm{SO}_{2}$ concentration to the monitoring network as from other directions. Although the Colstrip power plant plumes have been clearly identified, the quantitative levels of sulfur dioxide are very low. With respect to both exposures and maximum observable concentrations, we certainly are dealing in the parts per billion range.

Prior estimates of the extent of downwind sulfur dioxide fumigation were negligible with respect to the data presented here. In all specific cases studied beyond three miles the actual exposures were at least twice that predicted by field models in use, and generally more. Monthly averaged data as well as individual case situations indicate that although peak exposures may change dramatically with distance, the integrated exposures do not. The atmospheric models do not suggest this and, therefore, diverge from the measured values with distance. The high monthly values measured 7 miles from the power plant at Hay Coulee may well represent approximate exposures further downwind. These data strongly suggest longer-range monitoring information is necessary to improve power plant siting criteria.

The biological impact of the power plants has been under study for some time. Results from such work are reported on a continuing basis from the 
Corvallis, EPA. (16) Three of the monitoring stations were co-located within rangeland plots that were set aside specifically for assessing biological changes in the power plant environment. Subtle effects on the biota, with time, have been noted in the experimental data prior to and during our monitoring program. These may now be compared with our data to determine if correlations with long-term low-level chronic sulfur dioxide exposures exist. 


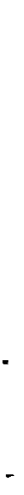




\section{REFERENCES}

1. D. J. Moore, "SO2 Concentration Measurements Near Tilbury Power Station," Atmospheric Environment. 1:389-410, 1967.

2. A Martin and F. R. Barber, "Investigation of Sulphur Dioxide Around Modern Power Stations," J. Inst. Fuel. 39:294-307, 1966.

3. A. Martin and F. R. Barber, "Sulphur Dioxide Concentrations Measured at Various Distances from a Modern Power Stations," Atmospheric Environment. $1: 655-677,1967$.

4. A. Martin and F. R. Barber, "Further Measurements Around Modern Pcwer Stations - I - III," Atmospheric Environment. 7:17-37, 1973.

5. R. A. Barnes, "Long-Term Mean Concentrations of Atmospheric Smoke and Sulphur Dioxide in Country Areas of England and Wales," Atmospheric Environment. 10:619-631, 1976.

6. H. Zeedijk and C. Velds, "The Transport of Sulphur Dioxide Over a Long Distance," Atmospheric Environment. 7:849-862, 1973.

7. G. S. Raynor, M. E. Smith and I. A. Singer, "Meteorological Effects on Sulfur Dioxide Concentrations on Suburban Long Island, New York," Atmospheric Environment. 8:1305-1320, 1974.

8. P. Zannetti, P. Melli and E. Runca, "Meteorological Factors Affecting $\mathrm{SO}_{2}$ Pollution Levels in Venice," Atmospheric Environment. 11:605-616, 1977.

9. J. D. Ludwick, T. D. Fox and L. L. Wendell, "Ozone and Radionuclide Correlations in Air of Marine Trajectory at Quillayute, Washington," J. Air Pollut. Control Assoc. 26:565-569, 1976.

10. C. E. Junge, Air Chemistry and Radioactivity. Academic Press, New York, 1963 .

11. D. D. Davis, G. Smith and G. Klauber, "Trace Gas Analys is of Power Plant Plumes via Aircraft Measurements: $\mathrm{O}_{3}, \mathrm{NO}_{x}$ and $\mathrm{SO}_{2}$ Chemistry, "Science. 186:733-736, 1974 .

12. A. Miller, "Rural and Urban Ozone Relationships," J. Air Pollut. Control AssOC. 24:819-821, 1974 .

13. G. Drufuca and M. Giugliano, "The Duration of High $\mathrm{SO}_{2}$ Concentrations in an Urban Atmosphere," Atmospheric Environment. 11:729-735, 1977.

14. C. E. Zimmer and G. A. Jutze, "An Evaluation of Continuous Air Quality Data," J.Air Pollut. Control Assoc. 14:262-266, 1964. 
15. E. A. Crecelius, J. C. Laul, L. A. Rancitelli and R. L. McKeever, "BaseIine Air Quality Data from Colstrip, Montana, "Pacific Northwest Laboratory Annual Report for 1975 to the USERDA Division of Biomedical and Environmental Research, Part 3, Atmospheric Sciences, BNWL-2000 PT3 Battelle-Northwest, RichTand, WA, pp. 25-26, 1976.

16. E. M. Preston and T. L. Gullett, The Bioenvironmental Impact of a CoalFired Power Plant, Fourth Interim Report Colstrip, Montana EPA-600/3-79044, U.S. Environmental Protection Agency, Corval1is, Oregon, 1979. 
APPENDIX A

A QUALITY ASSURANCE PROGRAM FOR DATA

VALIDATION AT COLSTRIP, MONTANA 


\section{A QUALITY ASSURANCE PROGRAM FOR DATA VALIDATION AT COLSTRIP, MONTANA}

This appendix focuses on the evolution of procedures undertaken by Pacific Northwest Laboratory to insure the quality of ozone and sulfur gas data produced at the Colstrip air monitoring stations since August 1977. As shortcomings in the initial quality assurance (QA) plan became apparent, more elaborate and redundant self-checking techniques were developed to guarantee the integrity of the generated numbers. It is believed that the final quality assurance plan, to the extent possible, covered all error sources in the framework of field applications. Our primary concern was the quality assurance of ozone and sulfur. These instruments were known to be subject to a large amount of long-term drift. Other measured parameters such as flow readings, etc., have proven stability. Nonetheless, all other systems and parameters utilized were referenced on a semiannual basis against reliable standards. At no point did these other parameters fall outside the $\pm 10 \%$ error margin limits.

The general procedure for checking the ozone and sulfur gas analyzers was to correlate the instrumental response with the known value of the concentration of an injected gas generated by a dynamic calibration unit. Sulfur dioxide gas was generated from a $\operatorname{Teflon}^{*}$ NBS permeation tube in a temperature-controlled oven. Ozone was created by flowing zero air past a stable ultraviolet lamp. If the response was within $10 \%$ of the known value of the injected gas, the instrument was not adjusted. If the response exceeded this error 1 imit, then, after correctly adjusting the zero and span potentiometers, a 4 or 5 point calibration was performed on the analyzer. Then, the instrumental calibration was checked for linearity and if found lacking $(r>.999)$ the instrument was removed from service and repaired.

Initially, we maintained one Monitor Labs Model 8500 calibrator onsite to perform weekly zero/span checks of our sulfur and ozone monitors. A second 8500 calibrator was kept in Corvallis, Oregon and referenced to NBS 
standards or Federal Code of Regulations Title 40 techniques. The calibrators were rotated every 4 months to provide a continuously updated reference source. This procedure worked effectively for one site only. As the number of stations rose to four, both calibrators were kept onsite (after June 1978). This was necessary in order to have at least a weekly check on each station, since 2 days are involved per site per calibration. One day is used to allow the calibrator to reach equilibrium. These calibrators were cross-referenced against each other on a weekiy basis. At the same time we obtained a Bendix Dynacalibrator from the Forest Service which was used as a fixed base for checking our mobile calibrators. We now check weekly the sulfur channels of the mobile ML8500 calibrators against an NBS tube in the stationary Bendix instrument. This is the same technique performed in corvallis. Also, the ozone channels are referenced to an ultraviolet ozone source in the Bendix calibrator. Our present observations have shown that the principal cause of change in calibrations is the act of moving the calibrator from one site to the next. Considering the locations of our sites and the type of country traversed, this is not surprising. We have observed a calibrator to change $30 \%$ in 3 weeks. This is the rationale for changing the initial quality assurance plan. Calibrators standardized at Corvalitis and returned to the field would have a functional period of about 1 week. The initial quality assurance plan worked well under the initial monitoring conditions of only one or two sites. Under current conditions, continuous referencing is necessary. Our current use of UV generated ozone as a standard is considered by us to be inadequate. The long term stability of UV lamps is known to be questionable. The neutral buffered KI method used at corvallis is also questionable. (a) Therefore, we are now using a gas phase titration. (b) This is the technique currently being utilized by the Rockwell auditing team. At the October 1978 audit we standardized our certified cylinder against the Rockwell NBS cylinder. We then used this standard to check weekly the ozone

(a) Interagency comparison of Iodometric Methods for Ozone Determination, W. B. Moore et al., Calibration in Zir Monitoring, ASTM Publication \#598, 1976.

(b) Application of Gas Phase Titration in the Calibration of Nitric Oxide, Nitrogen Dioxide and Ozone Analyzers, K. A. Rheme, Calibration in Air Monitoring, ASTM Publication $\# 598,1976$. 
channels of our mobile calibrators. The UV lamp is referenced to a certified nitric oxide cylinder by a gas phase titration using a nitrogen oxide analyzer as an intermediary. Alternately, a reverse gas phase titration was utilized with an ozone analyzer as an intermediary.

The zero/span records in this appendix span the time period since installation of the computerized data acquisition system. Records are also available from August 1977 through February 1978 at the Hay Coulee site. However, the data transcription during this early period was into stripcharts, relayed directly to the Corvalitis, EPA Laboratory; neither these records nor the monitoring data are included in this document. Large breaks in time during the records may be due to an inoperative analyzer or an inoperative site. The time periods expressed in the data should be checked against the appropriate time periods of the quality assurance records. All values are documented as parts per billion at local pressure. The local pressure is approximately $670 \mathrm{mmHg}$.

The state of the quality assurance program at the monitoring stations was audited quarterly by an independent contractor of the EPA (Rockwel1 International, Atomics International Division, Air Monitoring Center). The audits reflect an evolution of procedures and understanding by the auditors themselves. The audit reports are included at the end of the appendix. The first two audits demonstrated the reliability of the ozone analyzer, but abnormaliy low results were obtained for sulfur dioxide. This prompted an investigation into probable causes. It was found that $\mathrm{CO}_{2}$ levels created in the monitoring trailers by personnel respiration quenched the $\mathrm{SO}_{2}$ response during audit days only as a result of improper auditor procedures. (See "Field Experience with Ambient Level Flame Photometric Sulfur Detectors" in Appendix B.) The January audit had more $\mathrm{CO}_{2}$ interference than the September audit because the trailer was closed up tight for the winter and $\mathrm{CO}_{2}$ reached higher levels inside the monitoring trailer. All of our calibrations used external air tapped at the manifold as a base for generating span gases, while the auditing team used air from inside the trailer. Subsequent audits utilizing outside zero air after January 1978 demonstrate the validity of the 
$\mathrm{SO}_{2}$ data throughout the project. The July 1978 audit demonstrated the drift problem in two mobile calibrators and led to the establishment of a base calibrator. The final audits reflect the improved reliability of our quality assurance plan. All audits experienced a minor but important anomaly. The audit teams' zero air was usually 3-5 ppb higher in $\mathrm{SO}_{2}$ than ambient Colstrip air. This was probably caused by residual pollution in the audit equipment left from its storage and use in heavily polluted areas. It is interesting to note that the air in the Colstrip area, except during periods of power plant fumigation, contributes less $\mathrm{SO}_{2}$ instrumental response than the auditor zero air. Zero air problems such as this are commonly encountered throughout the literature in ultra-trace gas analysis.

Anyone attempting an ambient air monitoring project of this nature should be aware of the complications experienced with different quality assurance procedures.

A summary of pertient QA facts follows:

1) A single reference source is insufficient.

2) The user should be aware of interference present in the ambient gases and calibrate appropriately in their presence.

3) Complete onsite calibration facilities are preferred to remote calibration of calibrators, or to transport of calibration equipment.

4) Simplicity of techniques should be stressed. (Permeation tubes and GPT versus wet chemical methods.)

5) Every discrepancy is to be questioned thoroughly. Auditors are not perfect. 
ZERO/SPAN RECORDS

HAY COULEE DZONE

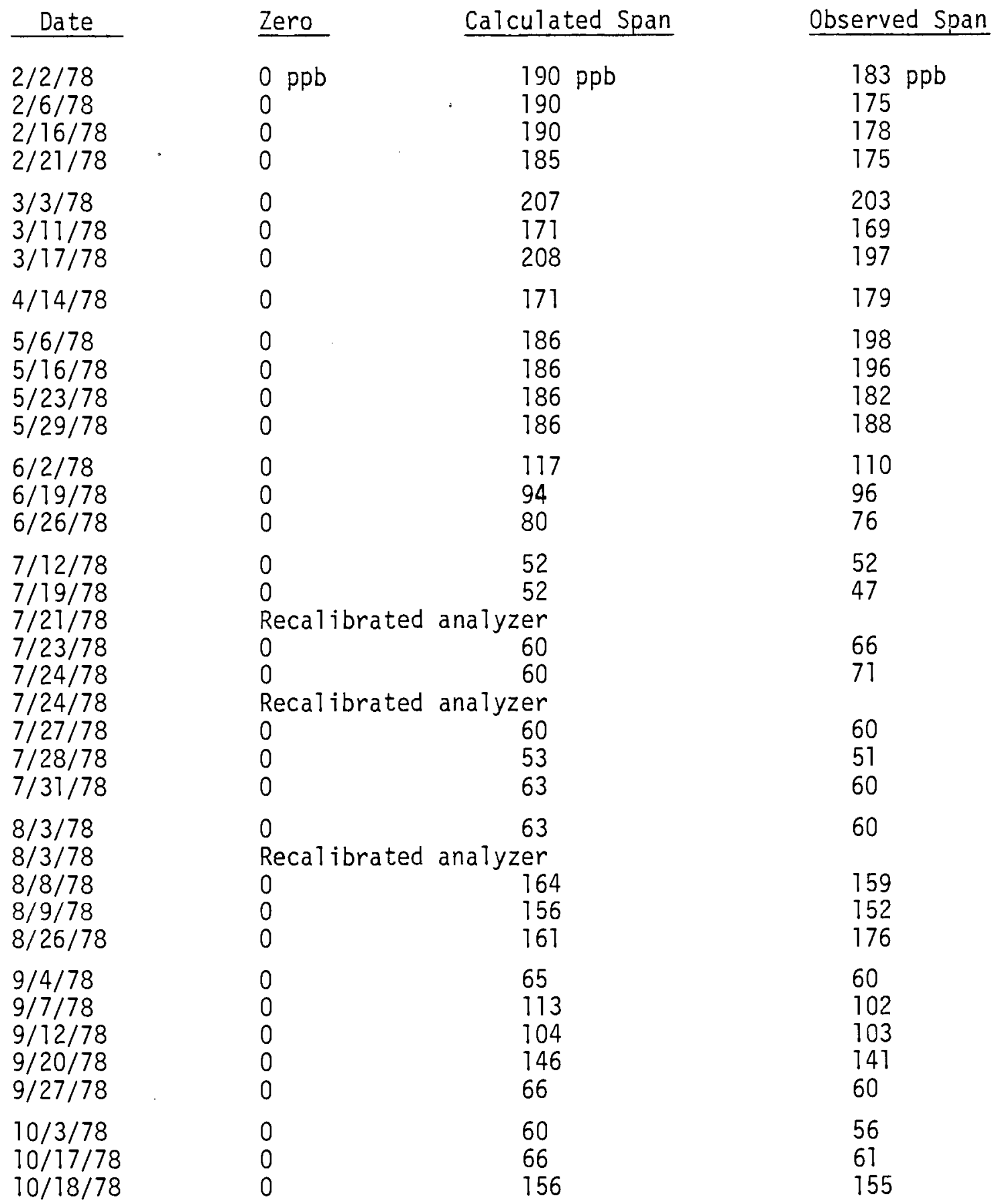

A. 5 


\section{ZERO/SPAN RECORDS \\ HAY COULEE OZONE (CONTINUED)}

\begin{tabular}{l}
\multicolumn{1}{c}{ Date } \\
\hline $11 / 7 / 78$ \\
$11 / 14 / 78$ \\
$11 / 19 / 78$ \\
$11 / 28 / 78$ \\
$12 / 28 / 78$ \\
$1 / 27 / 78$ \\
$2 / 1 / 78$ \\
$2 / 5 / 79$ \\
$2 / 11 / 79$ \\
\hline
\end{tabular}

Zero

Calculated Span

Observed Span

0

0

0

$+1$

98

62

119

45

$+1$

139

96

69

131

48

$+1$

45

135

$+1$

Recalibrated analyzer

0

168

48

150

162

\section{Instrumentation}

Monitor Labs Model 8410 EPA S/N 067838 


\section{ZERO/SPAN RECORDS}

HAY COULEE SULFUR GAS

\begin{tabular}{|c|c|c|}
\hline Date & Calculated Span & Observed Span \\
\hline $\begin{array}{l}2 / 2 / 78 \\
2 / 2 / 78 \\
2 / 6 / 78 \\
2 / 7 / 78\end{array}$ & $\begin{array}{lr}0 \mathrm{ppb} & 27 \mathrm{ppb} \\
\text { Recalibrated analyzer } \\
3 & 32 \\
-2 & 62\end{array}$ & $\begin{array}{l}36 \mathrm{ppb} \\
30 \\
57\end{array}$ \\
\hline $\begin{array}{l}3 / 17 / 78 \\
3 / 28 / 78\end{array}$ & $\begin{array}{l}0 \\
-5\end{array}$ & $\begin{array}{l}69 \\
26\end{array}$ \\
\hline $4 / 74 / 78$ & 75 & 74 \\
\hline $\begin{array}{l}5 / 23 / 78 \\
5 / 23 / 78 \\
5 / 24 / 78 \\
5 / 25 / 78 \\
5 / 27 / 78 \\
5 / 29 / 70 \\
5 / 31 / 78\end{array}$ & $\begin{array}{lc}0 & 75 \\
\text { Calibrated new analyzer } \\
1 & 28 \\
0 & 28 \\
1 & 28 \\
-3 & 28 \\
0 & 28\end{array}$ & $\begin{array}{l}75 \\
25 \\
28 \\
25 \\
28 \\
25\end{array}$ \\
\hline $\begin{array}{l}6 / 2 / 78 \\
6 / 10 / 78 \\
6 / 16 / 78 \\
6 / 20 / 78 \\
6 / 26 / 78\end{array}$ & $\begin{array}{l}0 \\
0 \\
0 \\
+3 \\
+6\end{array}$ & $\begin{array}{l}65 \\
27 \\
29 \\
26 \\
29\end{array}$ \\
\hline $\begin{array}{l}7 / 13 / 78 \\
7 / 18 / 78 \\
7 / 19 / 78 \\
7 / 21 / 78 \\
7 / 23 / 78 \\
7 / 27 / 78 \\
7 / 28 / 78 \\
7 / 31 / 78\end{array}$ & $\begin{array}{lr}\text { Recalibrated analyzer } \\
2 & 29 \\
\text { Recalibrated analyzer } \\
2 & 29 \\
3 & 29 \\
2 & 29 \\
1 & 29 \\
0 & 43\end{array}$ & $\begin{array}{l}23 \\
29 \\
29 \\
27 \\
29 \\
43\end{array}$ \\
\hline $\begin{array}{l}8 / 13 / 78 \\
8 / 15 / 78 \\
8 / 31 / 78\end{array}$ & $\begin{array}{l}-1 \\
0 \\
0\end{array}$ & $\begin{array}{l}64 \\
47 \\
79\end{array}$ \\
\hline $\begin{array}{l}9 / 6 / 78 \\
9 / 7 / 78 \\
9 / 12 / 78 \\
9 / 20 / 78 \\
9 / 27 / 76\end{array}$ & $\begin{array}{l}-2 \\
-2 \\
0 \\
+2 \\
-4\end{array}$ & $\begin{array}{l}70 \\
37 \\
42 \\
63 \\
69\end{array}$ \\
\hline $\begin{array}{l}10 / 3 / 78 \\
10 / 6 / 78 \\
10 / 12 / 78\end{array}$ & $\begin{array}{l}+2 \\
+1 \\
+2\end{array}$ & $\begin{array}{l}67 \\
44 \\
44\end{array}$ \\
\hline
\end{tabular}




\section{ZERO/SPAN RECORDS}

HAY COULEE SULFUR GAS (CONTINUED)

\begin{tabular}{l} 
Date \\
\hline $10 / 17 / 78$ \\
$10 / 18 / 78$ \\
$10 / 23 / 78$ \\
$10 / 23 / 78$ \\
$10 / 26 / 78$ \\
$10 / 28 / 78$ \\
$11 / 2 / 78$ \\
$11 / 7 / 78$ \\
$11 / 14 / 78$ \\
$11 / 19 / 78$ \\
$11 / 28 / 78$ \\
$12 / 6 / 78$ \\
$12 / 12 / 78$ \\
$1 / 3 / 79$ \\
$1 / 11 / 79$ \\
$1 / 18 / 79$ \\
$1 / 18 / 79$ \\
$1 / 24 / 79$ \\
$1 / 30 / 79$ \\
$1 / 30 / 79$ \\
$2 / 1 / 79$ \\
$2 / 7 / 79$ \\
\hline
\end{tabular}

Zero

$+3$

Recalibrated analyzer

$+1$

Recalibrated Analyzer

$+2$

0

$-1$

0

$+3$

$+4$

$-5$

$+4$

$+3$

Calibrated new analyzer

$-2$

$-2$

Recalibrated analyzer

$-3$

$-1$

Recalibrated analyzer

$-1$

Calibrated new analyzer
Observed Span

$66 \mathrm{ppb}$

72

80

76

82

80

63

78

80

51

81

74

69

80

100

82

Instrumentation

$\begin{array}{lll}2 / 2 / 78-2 / 7 / 78 & \text { Meloy SA } 160 & \text { EPA S/N } 111602 \\ 2 / 7 / 78-5 / 23 / 78 & \text { Meloy SA 285 } & \text { S/N FL156 } \\ 5 / 23 / 78-5 / 27 / 78 & \text { Meloy SA 160 } & \text { EPA S/N 019981 } \\ 5 / 27 / 78-12 / 18 / 78 & \text { Meloy SA 285 } & \text { S/N FL156 } \\ 1 / 3 / 79-2 / 7 / 79 & \text { Meloy SA 285 } & \text { S/N 5JOF3 }\end{array}$




\section{ZERO/SPAN RECORDS}

BNWI OZONE

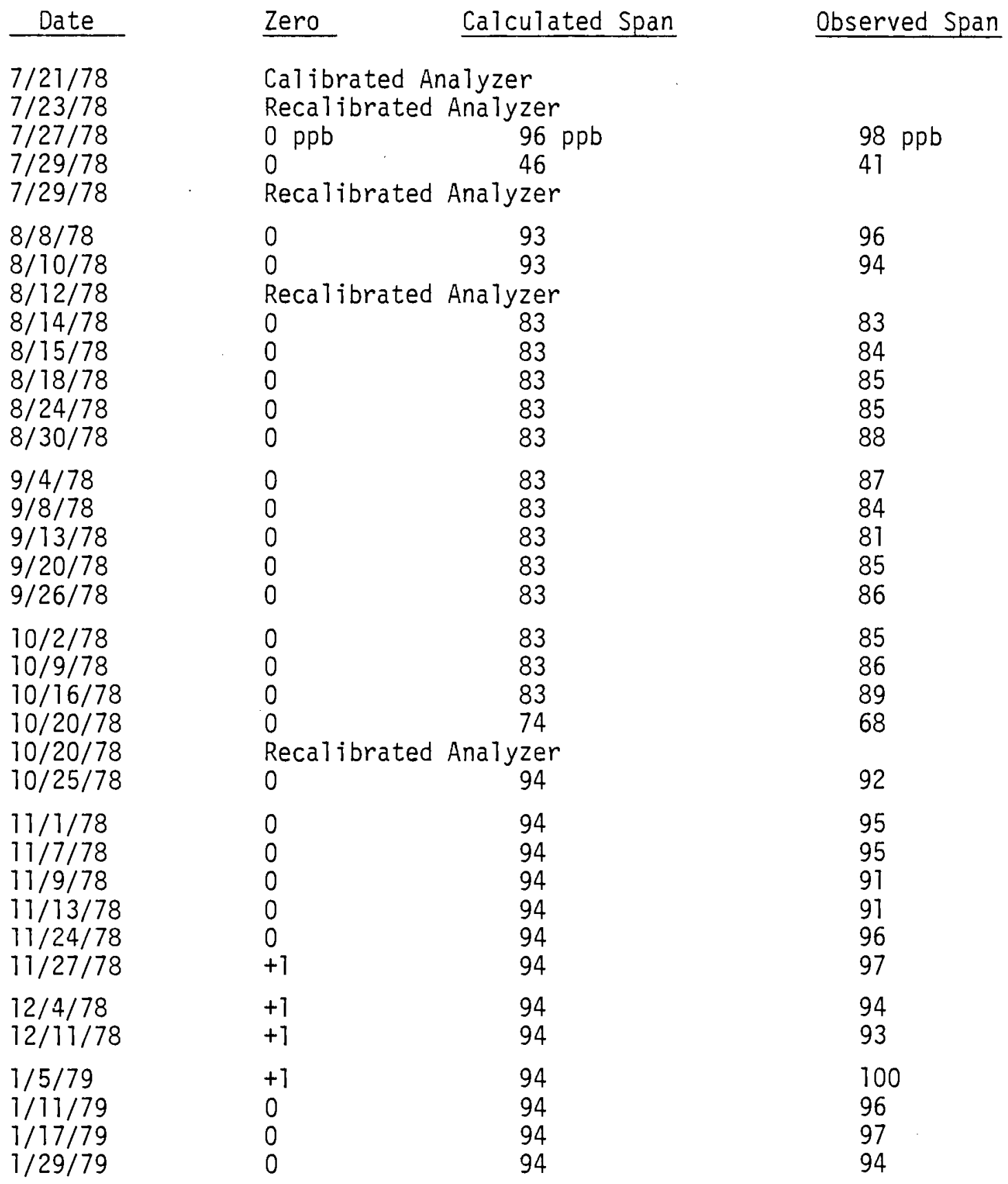




\section{ZERO/SPAN RECORDS}

BNWI OZONE (CONTIFUELD)

\begin{tabular}{l} 
Date \\
\hline $2 / 13 / 79$ \\
$2 / 15 / 79$ \\
$2 / 17 / 79$ \\
\hline
\end{tabular}

Zero

Calculated Span

Observed Span

Instrumentation Bendix Model 8002 Ozone Analyzer

$\begin{array}{ll}0 & 94\end{array}$

$+1$

94

94

100

$\begin{array}{ll}94 & 96 \\ 94 & 94 \\ 94 & 100\end{array}$


ZERO/SPAN RECORDS

BNWI SULFUR GAS

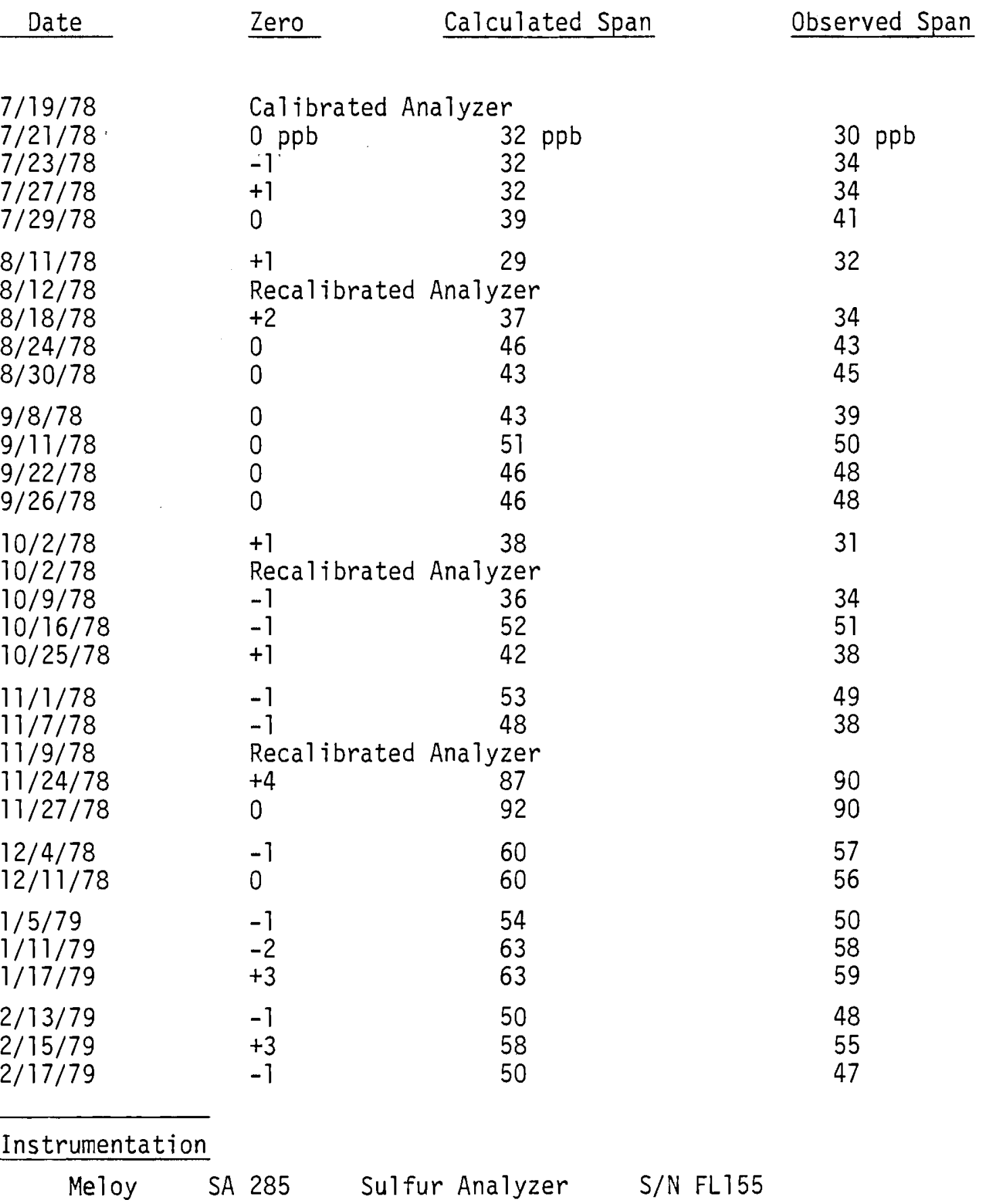




\section{ZERO/SPAN RECORDS}

\section{KLUVER EAST OZONE}

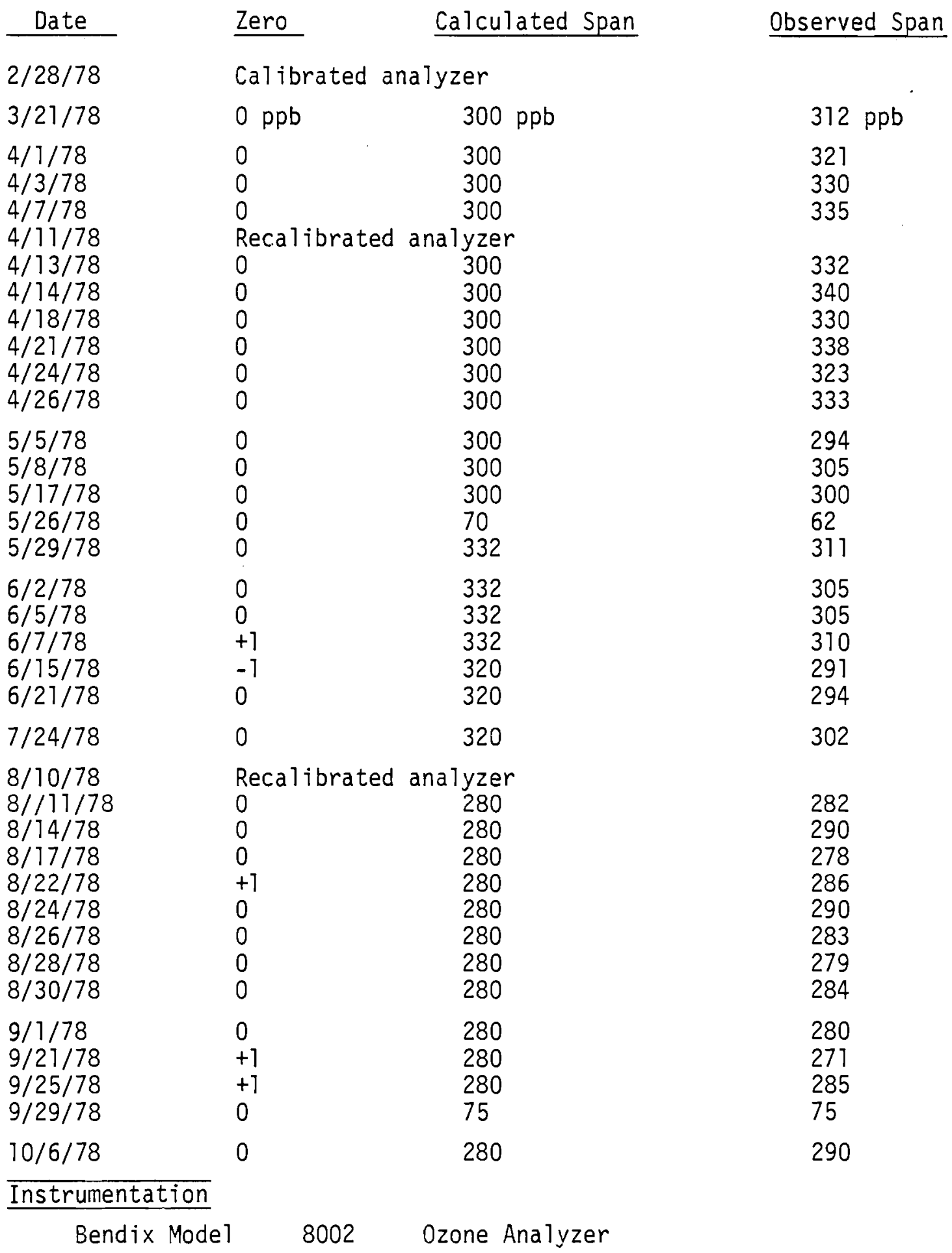




\section{ZERO/SPAN RECORDS}

KLUVER EAST SULFUR GAS

\begin{tabular}{l} 
Date \\
\hline $2 / 27 / 78$ \\
$3 / 20 / 78$ \\
$4 / 11 / 78$ \\
$5 / 26 / 78$ \\
$5 / 26 / 78$ \\
$6 / 21 / 78$ \\
$7 / 25 / 78$ \\
$8 / 11 / 78$ \\
$8 / 17 / 78$ \\
$8 / 17 / 78$ \\
$8 / 22 / 78$ \\
$8 / 30 / 78$ \\
$9 / 21 / 78$ \\
$9 / 29 / 78$ \\
$9 / 29 / 78$ \\
$10 / 16 / 78$
\end{tabular}

Zero

Calculated Span

Observed Span

Calibrated analyzer

Recalibrated analyzer

Recalibrated analyzer

$0 \mathrm{ppb} \quad 70 \mathrm{ppb}$

Recalibrated analyzer

$62 \mathrm{ppb}$

0

33

35

Recalibrated analyzer

Recalibrated analyzer

$+3$

28

Recalibrated analyzer

$0 \quad 51$

$+1 \quad 37$

48

$+3$

54

0

63

Recalibrated analyzer

$+2$

52

23

35

57

55

49

\section{Instrumentation}

Bendix Model 8002 Ozone Analyzer 


\section{ZERO/SPAN RECORDS}

KLUVER WEST OZONE

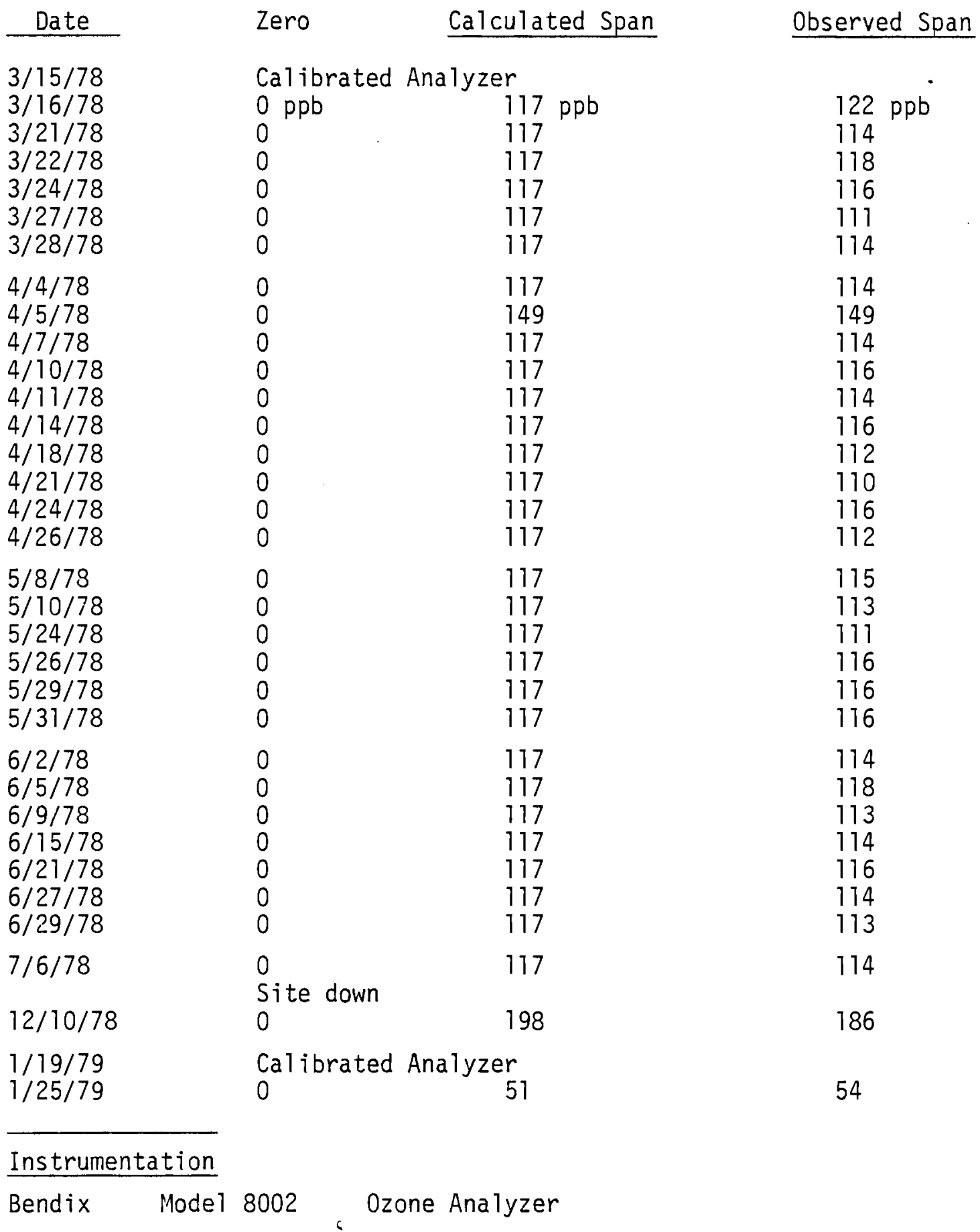




\section{ZERO/SPAN RECORDS}

KLUVER WEST SULFUR GAS

\begin{tabular}{|c|c|c|c|}
\hline Date & Zero & Calculated Span & Observed Span \\
\hline $\begin{array}{l}3 / 16 / 78 \\
3 / 22 / 78\end{array}$ & \multicolumn{3}{|c|}{$\begin{array}{l}\text { Calibrated Analyzer } \\
\text { Recalibrated Analyzer }\end{array}$} \\
\hline $4 / 5 / 78$ & \multicolumn{3}{|c|}{ Recalibrated Analyzer } \\
\hline $5 / 24 / 78$ & $0 \mathrm{ppb}$ & $70 \mathrm{ppb}$ & $70 \mathrm{ppb}$ \\
\hline $\begin{array}{l}6 / 5 / 78 \\
6 / 9 / 78 \\
6 / 16 / 78 \\
6 / 21 / 78 \\
6 / 29 / 78\end{array}$ & $\begin{array}{l}0 \\
-1 \\
+3 \\
0 \\
0\end{array}$ & $\begin{array}{l}29 \\
37 \\
28 \\
27 \\
33\end{array}$ & $\begin{array}{l}29 \\
30 \\
26 \\
25 \\
33\end{array}$ \\
\hline \multirow[t]{2}{*}{$\begin{array}{l}7 / 6 / 78 \\
7 / 6 / 78\end{array}$} & \multicolumn{2}{|c|}{$\begin{array}{lc}0 & 34 \\
\text { Recal ibrated Analyzer }\end{array}$} & 39 \\
\hline & \multicolumn{2}{|c|}{ Site down } & \\
\hline $12 / 7 / 78$ & \multicolumn{2}{|c|}{ Calibrated Analyzer } & \\
\hline $\begin{array}{l}1 / 19 / 70 \\
1 / 25 / 79\end{array}$ & $\begin{array}{l}0 \\
-1\end{array}$ & $\begin{array}{l}77 \\
77\end{array}$ & $\begin{array}{l}69 \\
71\end{array}$ \\
\hline
\end{tabular}

Instrumentation
Meloy
SA 285 Sulfur Analyzer

A. 15 


\section{ZERO/SPAN RECORDS}

KLUVER NORTH SULFUR GAS

\begin{tabular}{l}
\multicolumn{1}{c}{ Date } \\
\hline $8 / 10 / 78$ \\
$9 / 4 / 78$ \\
$10 / 30 / 78$ \\
$11 / 6 / 78$ \\
$11 / 14 / 78$ \\
$11 / 20 / 78$ \\
$12 / 1 / 78$ \\
$12 / 8 / 78$ \\
$1 / 6 / 78$ \\
$1 / 6 / 78$ \\
$1 / 12 / 78$ \\
$1 / 19 / 78$ \\
$1 / 27 / 79$ \\
$2 / 6 / 79$ \\
\hline
\end{tabular}

Zero

Calculated Span

Observed Span

Calibrated Analyzer

Recalibrated Analyzer

Recalibrated Analyzer

$-1 \mathrm{ppb} \quad 48 \mathrm{ppb}$

$+2 \quad 84$

$44 \mathrm{ppb}$

$+6$

84

$+1 \quad 58$

77

$+2$

57

53

$-3$

62

52

Recalibrated Analyzer

$+1$

$-2$

62

73

0

62

54

0

62

59

69

58

60

Instrumentation

Meloy SA 285 Sulfur Analyzer


ZERO/SPAN RECORDS

KLUVER NORTH OZONE

\begin{tabular}{|c|c|c|}
\hline Date & Zero & Observed Span \\
\hline $\begin{array}{l}7 / 17 / 78 \\
7 / 18 / 78 \\
7 / 19 / 78 \\
7 / 23 / 78 \\
7 / 24 / 78 \\
7 / 26 / 78 \\
7 / 28 / 78\end{array}$ & $\begin{array}{l}\mathrm{Ca} 1 \mathrm{i} \\
0 \mathrm{pp} \\
0 \\
0 \\
0 \\
0 \\
0\end{array}$ & $\begin{array}{l}171 \mathrm{ppb} \\
176 \\
172 \\
171 \\
173 \\
173\end{array}$ \\
\hline $\begin{array}{l}8 / 2 / 78 \\
8 / 4 / 78 \\
8 / 10 / 78 \\
8 / 15 / 78 \\
8 / 31 / 78\end{array}$ & $\begin{array}{l}0 \\
0 \\
\operatorname{Rec} a \\
0 \\
0\end{array}$ & $\begin{array}{l}173 \\
178 \\
159 \\
150\end{array}$ \\
\hline $10 / 30 / 78$ & $\operatorname{Rec} a$ & \\
\hline $\begin{array}{l}11 / 6 / 78 \\
11 / 14 / 78 \\
11 / 29 / 78\end{array}$ & $\begin{array}{l}+1 \\
0 \\
0\end{array}$ & $\begin{array}{l}275 \\
265 \\
274\end{array}$ \\
\hline $\begin{array}{l}12 / 1 / 78 \\
12 / 8 / 78 \\
12 / 8 / 78\end{array}$ & $\begin{array}{l}0 \\
0 \\
\operatorname{Rec} a\end{array}$ & $\begin{array}{l}269 \\
260\end{array}$ \\
\hline $\begin{array}{l}1 / 2 / 79 \\
1 / 6 / 79 \\
1 / 6 / 79 \\
1 / 12 / 79 \\
1 / 19 / 79 \\
1 / 27 / 79\end{array}$ & $\begin{array}{l}0 \\
+1 \\
\operatorname{Rec} \\
+1 \\
0 \\
0\end{array}$ & $\begin{array}{l}306 \\
302 \\
\\
233 \\
238 \\
236\end{array}$ \\
\hline $2 / 6 / 79$ & 0 & 235 \\
\hline
\end{tabular}

Instrumentation

Bendix Model 8002 Ozone Analyzer 


\section{ZERO/SPAN RECORDS}

GREENLEAF OZONE

\begin{tabular}{l}
\multicolumn{1}{c}{ Date } \\
\hline $9 / 20 / 78$ \\
$9 / 26 / 78$ \\
$10 / 7 / 78$ \\
$10 / 11 / 78$ \\
$10 / 16 / 78$ \\
\hline
\end{tabular}

Zero Calculated Span

Observed Span

Calibrated Analyzer

0 ppb

$188 \mathrm{ppb}$

0

$+1$

0

188

188

188

$184 \mathrm{ppb}$

185

177

178

Instrumentation
Bendix
Mode1 8002
Ozone Analyzer 


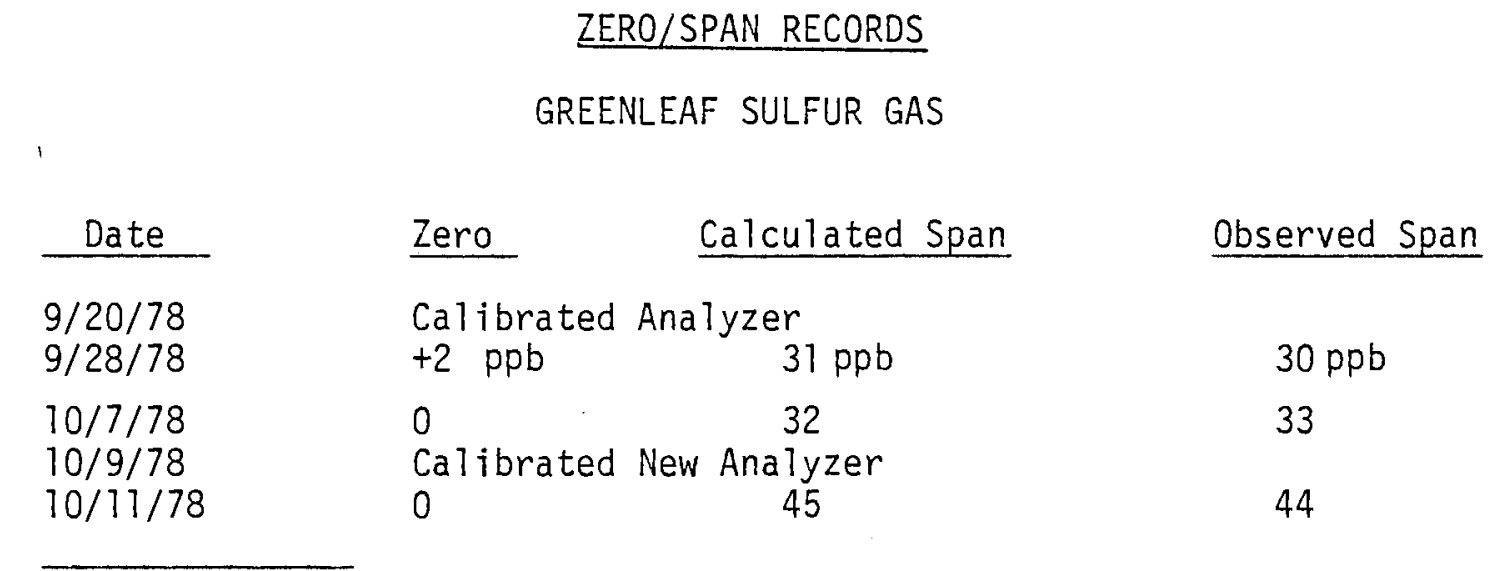

Instrumentation

$\begin{array}{llll}9 / 20 / 78-10 / 9 / 78 & \text { Meloy SA } 160 & \text { EPA S/N } 111601 \\ 10 / 9 / 78 \text {-end of measuring Meloy SA } 285 & \text { S/N FL154 }\end{array}$

A. 19 


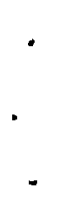


November 13, 1978

EMSC8303.1730AR

QUALITY ASSURANCE AUDIT REPORT

EPA COLSTRIP

October 20-21, 1978

Special Report to:

Environmental Protection Agency

Environmental Monitoring and Support Laboratory

Research Triangle Park, North Carolina 2771!

Contract No. 68-02-2412

Project Officer: Steven M. Bromberg

Prepared By:

A. E. Jackson

Approved By:

Or. Mark Cher

Program Manager

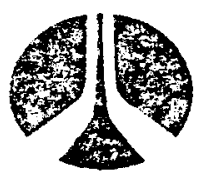

Rockwell International

Environmental Monitoring a Sarvices Center

Environmental \& Energy Systems Division

2421 West Hiltcrest Drive

Newbury Park, CA 91320

(805) 498.6771 


\section{QUALITY ASSURANCE AUDIT REPORT - COLSTRIP EPA STATION}

COLSTRIP, MONTANA

\section{SUMMARY}

This report describes the results obtained during the October 1978 audit of the analyzers in the Hae Koolie ${ }^{(b)}$ and B\&ls 1 sites operated by Battelle Corporation for the EPA and located in Colstrip, Montana. Results are presented by comparing concentration $C_{1}$, delivered by the audit device, with concentration $C_{2}$ predicted from the latest station calibration. The relationship is given by the equation $C_{2}=\beta C_{1}+\alpha$, where $\beta$ and $\alpha$ are the linear constants. Values of $\beta$ and $\alpha$ for the current audit are shown in the body of this report. Values for $\beta$ for the audits to date are listed below.

Site $B \& W 1$ in this audit report is the same station as the one described in the last audit report as the State of Montana trailer with EPA equipment.

Colstrip EPA Site (Hae Koolie)

\begin{tabular}{|c|c|c|c|c|c|c|}
\hline Channel & $9-21-77$ & $1-26-78$ & $4-17-78$ & $7-37-78$ & $10-20-78$ & $2-1-79^{(d)}$ \\
\hline $\mathrm{SO}_{2}$ & $0.867^{(c)}$ & $0.493^{(c)}$ & 0.889 & 1.216 & 0.914 & 0.922 \\
\hline $\mathrm{O}_{3}$ & 1.000 & 0.950 & 0.947 & 1.111 & 1.018 & 0.906 \\
\hline $\mathrm{NO} / \mathrm{NO}_{\mathrm{X}}$ & $\begin{array}{l}\text { no analyzer } \\
\text { currently } \\
\text { in use }\end{array}$ & $\begin{array}{l}\text { analyzer } \\
\text { inoperable }\end{array}$ & $\begin{array}{l}\text { analyzer } \\
\text { inoperable }\end{array}$ & $\begin{array}{l}\text { analyzer } \\
\text { removed } \\
\text { prior to } \\
\text { audit }\end{array}$ & $\begin{array}{l}\text { analyzer } \\
\text { not in } \\
\text { use }\end{array}$ & \\
\hline
\end{tabular}
$\mathrm{Hi}$ Vol
$+21.7$
(a)
(a)
(a)
(a)

B\&W 1 Site

$\begin{array}{cccccc}\mathrm{SO}_{2} & \ldots & \ldots & \ldots & 1.172 & 1.065 \\ \mathrm{O}_{3} & \ldots & \ldots & \ldots & 1.107 & 1.033\end{array}$

(a) Operation discontinued

(b) Correct spelling is Hay Coulee

(c) $\mathrm{CO}_{2}$ interference present during audit; see Appendix $\mathrm{B}$.

(d) Information from later audit not included in the October 20, 1978 report. 


\section{INTROOUCTION}

This report describes the results of the field audits of the two Colstrip sites operated by Battelle Northwest for the EPA. The audit was performed by A. E. Jackson with Dave Weber and Khris 01 sen, both Battelle personnel, present for the audits.

METHODS

Rockwell - A detailed description of the apparatus, standard procedures, definitions and evaluation criteria is given in Appendices $A, B$, and $C$.

Standard pollutant sources used during this audit were as follows:

$$
\text { for } \begin{aligned}
\mathrm{SO}_{2}- & \text { an NBS-SRM Permeation tube } \# 39-36 \\
& \text { certified by NBS to give } 0.749 \mu \mathrm{g} / \mathrm{min} \\
& \text { at } 30.00^{\circ} \mathrm{C} \text {. }
\end{aligned}
$$

for NO - an Airco cylinder \#FF2787 certified by Rockwell to contain $104.1 \mathrm{ppm} \mathrm{NO}$ in $\mathrm{N}_{2}$.

Colstrip EPA - The station calibrations for both sites are accomplished by using a Monitor Labs 8500 Portable Calibrator, equipped with an ozone source. This is used in conjunction with a zero air supply and, for $\mathrm{SO}_{2}$ calibrations, an NBS-SRM $2 \mathrm{~cm} \mathrm{SO}$. permeation tube. Until this audit both the ozone source and the $\mathrm{SO}_{2}$ tube were previously crosschecked at Corvallis, oregon against vet chemical methods. This was done at regular intervals but has been recently discontinued in favor of in situ calibration of the ozone source by the gas phase titration technique and the substitution of an NBS-SRM SO 2 tube for the Monitor Labs device. The latest checks were made as listed in the body of this report by Khris oisen and Dave Weber.

\section{RESULTS}

Results of the audit are presented by plotting concentration $\mathrm{C}_{2}$ predicted by the latest state calibration against concentration $C_{1}$ delivered by the audit device. The relationship is described by the equation $C_{2}=3 C_{1}+\alpha$, where 3 
is the slope and $\alpha$ is the intercept. Figures 1-4 show graphs for each of the channels audited and Table I shows the vaiues of $\beta$ and $\alpha$. Also shown in Table I are the percent differences at full scale. These are calculated using the equation:

$$
\approx \text { Diff }=100 \cdot\left[(3-1)+\frac{\alpha}{x}\right]
$$

where $x$ is the maximum of the instrument operating range in ppm.

Table II presents the results in another manner. For each audit concentration $c_{1}$ the percent difference $\left(d_{j}\right)$ between it and the indicated station ppm output $C_{2}$ is calcuiated. These $d_{j}$ 's are then averaged over all audit data points for a given channel, and the resultant value $\left(\bar{d}_{j}\right)$ is used as a measure of station accuracy. The standard deviation $S_{j}$ is also presented to allow calculation of the 95\% upper and lower confidence levels of the data. Table III lists the average of averages and pooled standard deviation for this agency system. Appendices A, B, and C describe the data treatment in more detail.

The stations each contained the following instrumentation at the time of the audit:

\begin{tabular}{|c|c|c|c|c|}
\hline Channel & Analyzer & $\begin{array}{c}\text { Operating } \\
\text { Range }\end{array}$ & $\begin{array}{c}\text { Last } \\
\text { Calibration } \\
\end{array}$ & Method \\
\hline $0_{3}$ & $\begin{array}{l}\text { Monitor Labs } \\
\text { Model } 8410\end{array}$ & $0.0-0.2$ & & $\begin{array}{l}\text { Known source. } \\
\text { "Gas Phase Titration }\end{array}$ \\
\hline $\mathrm{SO}_{2}$ & $\begin{array}{l}\text { Meloy } \\
\text { Model } 285\end{array}$ & $0.0-0.1$ & $10 / 20-21 / 73$ & $\begin{array}{l}\text { NBS-SRM } \\
2 \mathrm{~cm} \text { perm tube }\end{array}$ \\
\hline
\end{tabular}

$\underline{\mathrm{SO}}_{2}$ Audits

Both audits resulted in 8 's which lie within the established $10 \%$ working criteria. For the Hae Koolie Site the 3 was 0.914, while that for the B\&W 1 Site was 1.065. At Hae koolie Site, when the upscale audit point was introduced a large difference was found between the Rockwell and Station values. Since the station equipment was available, a one-point span check was run and gave a result which accounted for a good portion of the problem. The 
B's listed above reflect the fact that all data were corrected for this suspected analyzer drift.

\section{Ozone Audits}

The audit of the ozone instrument.at the lae koolie site was run by gas phase titration making use of a TECO NO-NO ${ }_{x}$ analyzer present at that site. The audit of the $B \& W 1$ site was performed by using reverse gas phase titration. Both yielded $B$ values implying close agreement between the Rockwell and station ppm vaiues. No probiems were encountered at either site with analyzer linearity.

\section{Special Discussion}

Station personnel requested an on-the-spot crosscheck of the vendor's ppm value supplied with the NO cylinder currently used for gas phase titrations. This was accomplished by first calibrating the NO channel of the $\mathrm{NO}_{\mathrm{N}} \mathrm{NO}_{\mathrm{x}}$ analyzer at the Hae Koolie site using Rockwell's NBS-traceable standard cylinder and obtaining a ppm versus output voltage curve. The station cylinder was then plumbed through the portable audit device flow controller in exactly the same manner and concentration determinations made at four flow points. Rockwell found a value of 12.78 with a standard deviation of \pm 0.05 , while the Linde certified value given as 10.00 ppm. The Rockwell determined value will be used by station personnel for subsequent calibrations. 
TABLE I

Environmental \& Enargy Sygroms Division

AUDIT CONSTANTS FOR ANALYZERS

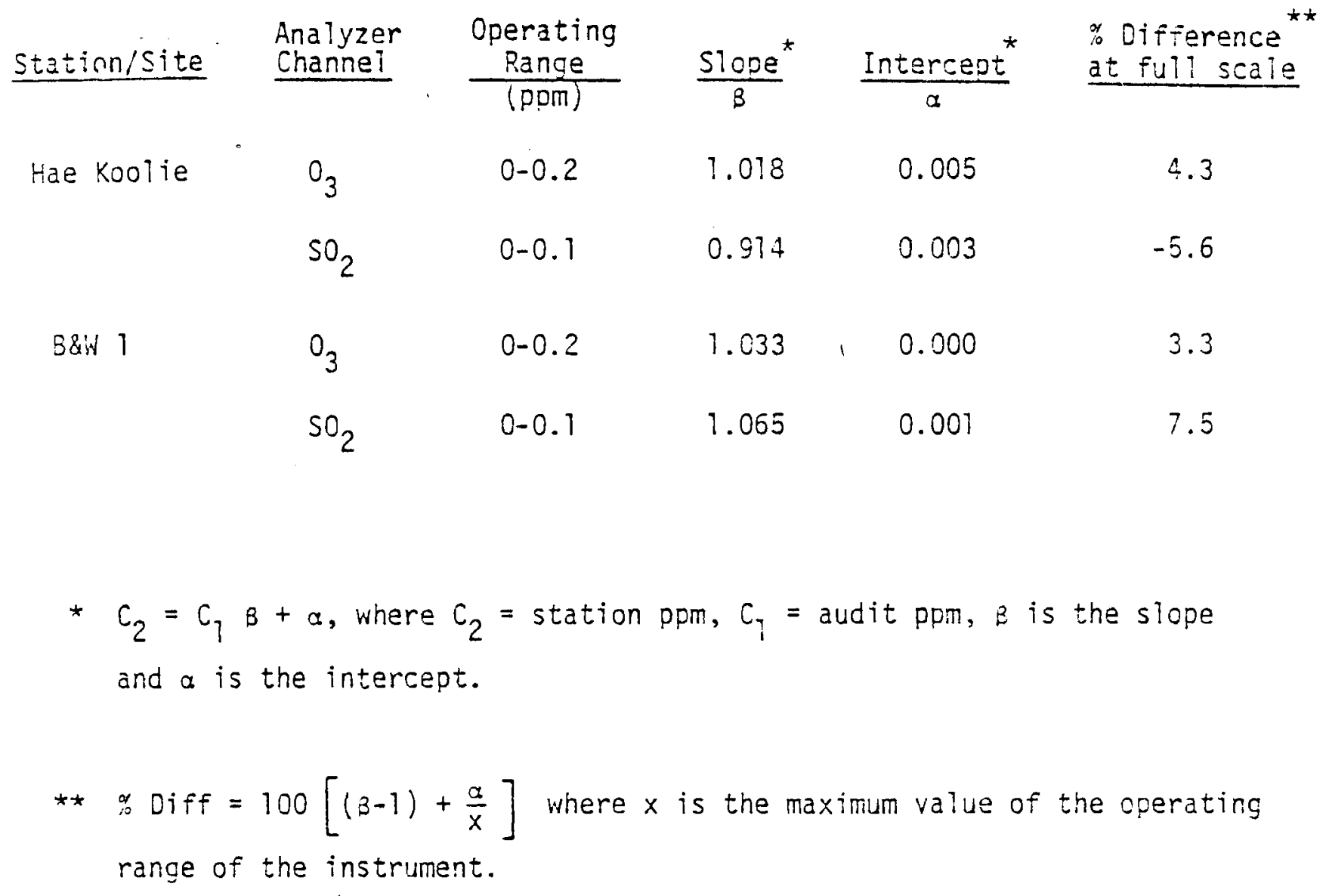




\section{TABLE II}

AUDIT AVERAGE $\%$ DIFFERENCES OF DATA POINTS

FOR EACH CHANNEL IN EACH STATION

\begin{tabular}{|c|c|c|c|c|c|c|}
\hline Station & Channel & $\begin{array}{l}\text { Operating } \\
\frac{\text { Ranqe }}{(\mathrm{ppm})}\end{array}$ & $\bar{d}_{j}{ }^{*}$ & $S_{j}^{*}$ & $U L^{*}$ & $\mathrm{LL}^{*}$ \\
\hline \multirow[t]{2}{*}{ Hae Koolie } & $\mathrm{O}_{3}$ & $0-0.2$ & 11.1 & 9.2 & 29.1 & -6.9 \\
\hline & $\mathrm{SO}_{2}$ & $0-0.1$ & -2.2 & 4.1 & 5.8 & -10.2 \\
\hline \multirow[t]{2}{*}{ B\&W $T$} & $\mathrm{O}_{3}$ & $0-0.2$ & 3.9 & 2.0 & 7.8 & 0.0 \\
\hline & $\mathrm{SO}_{2}$ & $0-0.1$ & 7.3 & 1.2 & 9.7 & 4.9 \\
\hline
\end{tabular}




\section{TABLE III}

AVERAGE OF AVERAGES - POOLED STANDARD DEVIATION

$\begin{array}{ccc}\text { Channel/Species } & \frac{\bar{D}^{*}}{7.5} & \frac{\mathrm{S}_{a}^{*}}{\mathrm{O}_{3}} \\ \mathrm{SO}_{2} & 4.8 & 6.6\end{array}$

* Calculation of $\bar{D}$ and $S_{a}$ are explained fully in the Appendix. 


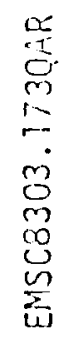

ә7!S ә! LOOX әен lof syde.19 - 2 pue 1 sa.n6!t

auozo ludd 7 !pny

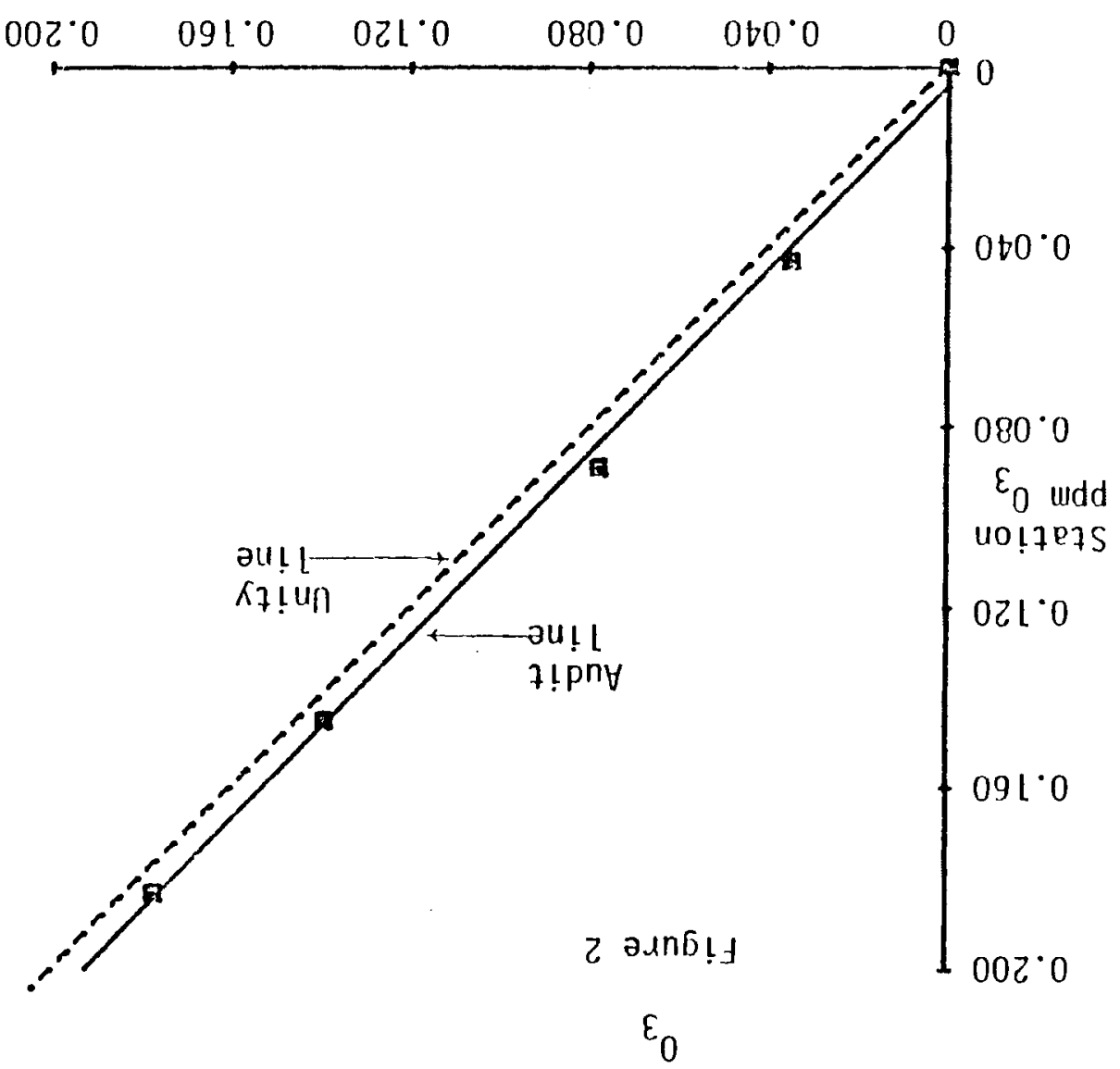

$\tau_{\text {OS }}$ udd 7 !pn

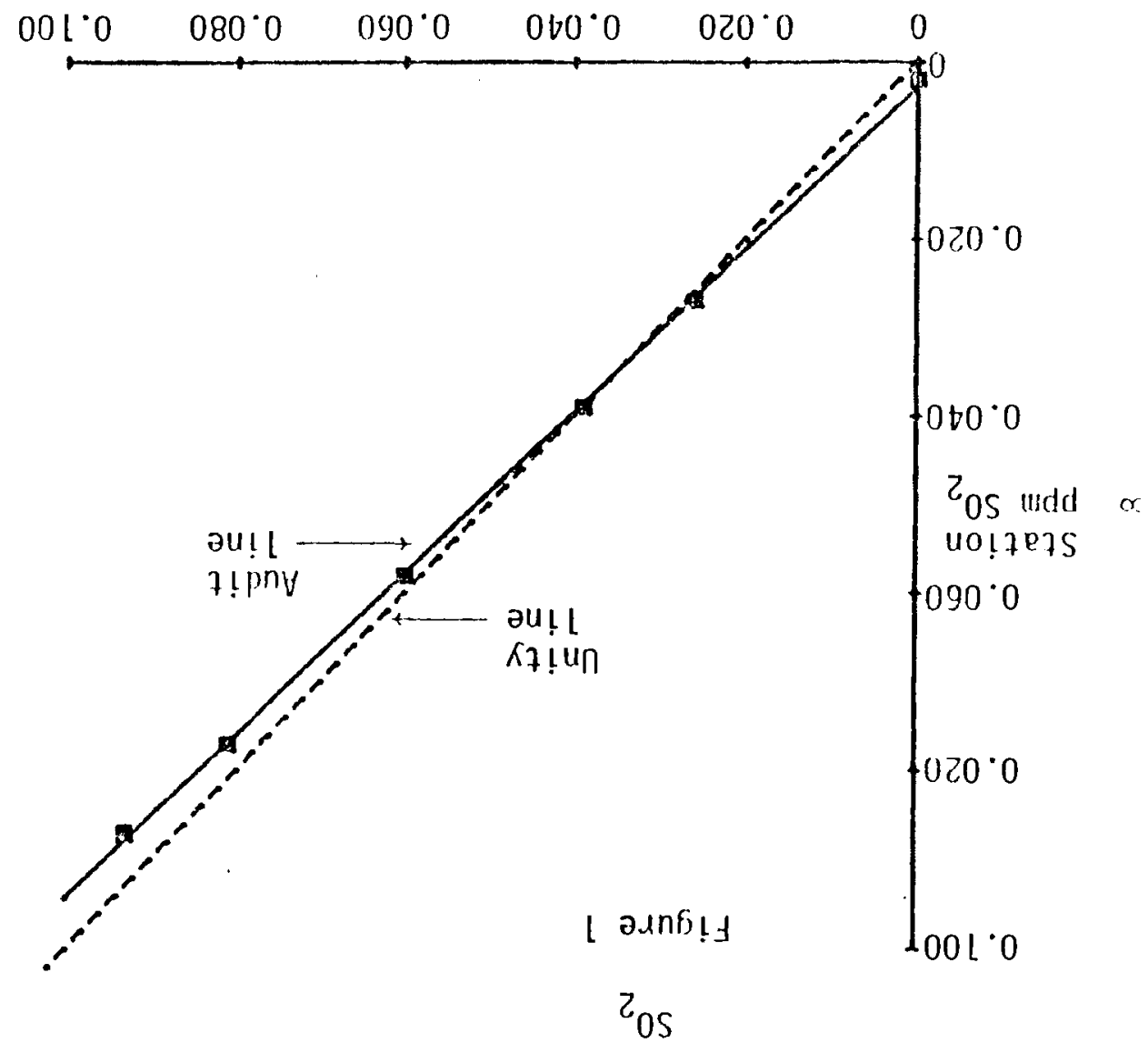




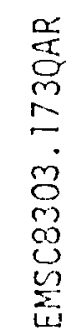

a)!s I M8g lof sydexg - t pue $\varepsilon$ sainfit
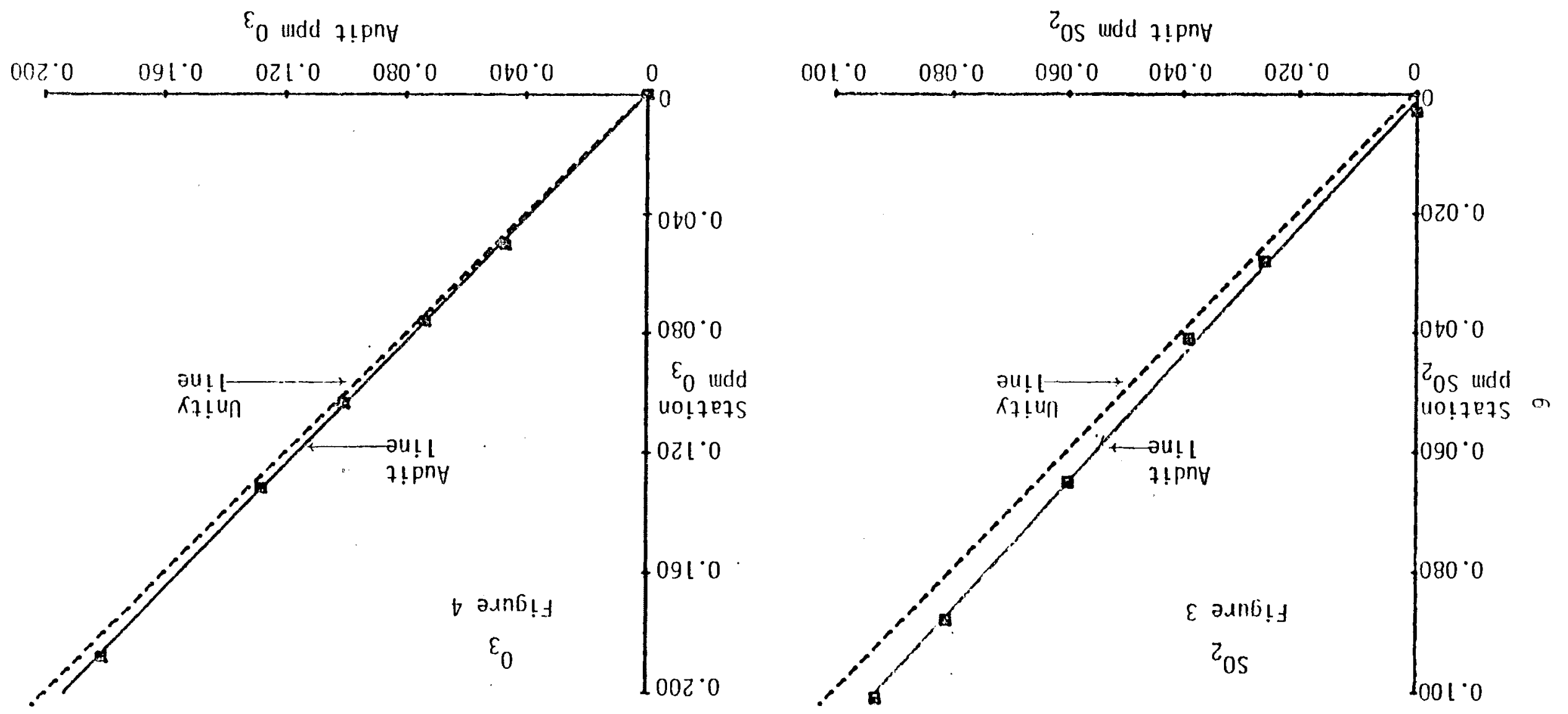

APPENOIX A

A description of the apparatus, calibration standards, audit procedures and evaluation criteria is presented in this appendix.

\section{APPARATUS ANO CALIBRATION STANDARDS}

The Rockwell portable audit device is used in the audits of all continuous monitors. The audit device was designed and built at the Rockwell Air Monitoring Center. The audit device is capable of generating and delivering mixtures of various gaseous poliutants in air at precisely known concentrations. Mixtures are produced in one of four ways:

1. By dilution of gases contaired in cylinders at high concentrations (e.g., $\mathrm{NO}, \mathrm{CO}, \mathrm{CH}_{4}$ ).

2. By gas phase titration (e.g. $\mathrm{NO}_{2}$ ).

3. By dilution of ozone produced by an ozone generator.

4. By dilution of gasas diffusing from permeation devices (e.g., $\mathrm{SO}_{2}$ ).

The audit device contains two Tylan mass flow controllers to controi and measure the flow of difution air and span gas from the high concentration cylinder. The span gas flow controller has a range of $0-50=0 /$ min. The dilution air flow controller has a range of $0-15000 \mathrm{cc} / \mathrm{min}$. Each of these flow controllers is calibrated before and after each trip. Flows are reproducibie and accurate to $\div$ i\%. Thus, dilutions by factors of $15000 / 5$ $=3000$ to $1500 / 50^{\circ}=30$ with an accuracy of $\pm 2 \%$ can be readily made by dialing the desired flow. Since flow controllers measure mass flow, the flow calibration is given in standard ce/min and it is indepencent of amoient temperature and pressure. 
The audit device has an air oven to maintain the temperatura at $30.0 \div 0.1^{\circ} \mathrm{C}$. A mercury-in-glass thermometer, graduated in $0.07^{\circ} \mathrm{C}$ divisions and calibrated against an NBS certified themometer, is used to read the temperature. The oven contains an ozone generating system and two separate Tefion permeation tube holders. The ozone is generated by means of a variable, current-controlled mercury lamp insertad in a Tefion block. Air flows through copper coils imersed in the air oven and reaches temperature equilibrium before entering the ozonizer block and the permeation tube holders. The air flow through these cavices is approximately $50 \mathrm{ce} / \mathrm{min}$, very much simaller than the dilution air ficw, and hence it is controlled and measured with suficient accuracy using needie valves and rotometers. All meterials exposed to ozone or $\mathrm{SO}_{2}$ are either Tefion or giass. Span gases passing through the fiow controliter are in contact with stainiess stael, Teilon and glass. Diluted gases are in contact with only Tefion or glass.

\section{A. Zero Air}

Zero air is generated from ambient air by means of a Rock'well-built, portabie, zero air scurce. Ambient air from a compressor is dried, ozonized, and passed through activated charcoal and a particulate filtar. The air can al so be passed through a catalytic oxidizer. Thus the zero air source delivers air which is essentially iree of $\mathrm{NO}, \mathrm{NO}_{2}, \mathrm{O}_{3}, \mathrm{SO}_{2}, \mathrm{CO}$ and hydrocarbons at a flow and pressure which mest the specifications of the difution air flow controller used in the portable audit device. The quality of the zero air has been tested at the Rockwell QA laboratory, and has been found to meet the standards required of field audits.

\section{Mitric Oxide (No)}

The No standards are cylinders containing approximateiy 100 pom 10 in nitrogen. The eylinders are enajyzed at the AMC by diract one-to-one comparison with a Standart Refarance Material (S.MM) cylinder obtained From the National 3ursau of Standards (N8S) and containing aporoximataly the same 
concentration of NO. The analysis is done using a dilution system and a NO-NO $x$ analyzer. Identical difution flows are used to eliminate fiow measursment errors. The 10 cylinders are also analyzed for $\mathrm{NO}_{2}$ by the Saltzman method to insura that the $\mathrm{NO}_{2}$ content is less than 0. . $_{*}$ of the NO content.

\section{c. Nitrogen Dioxide $\left(\mathrm{NO}_{2}\right)$ and Ozone $\left(\mathrm{O}_{3}\right)$}

$\mathrm{NO}_{2}$ is generated in the gas phase titration of $\mathrm{NO}$ with ozone. The concentration of $\mathrm{NO}_{2}$ is detenmined with a previously cal ibratad $\mathrm{HO}$ analyzer (using the No standard) by measuring the decrease in NO concentration as ozone is added to the $N O \mathrm{flcw}$. This procedure, in effect, caibrates the ozone lamp in the audit device at the ambient conditions in the site. The No flow is then urned ofi, and the calibrated ozone lamp is used to aldit the $\mathrm{O}_{3}$ analyzer calibration. Except for special circumstances described separately, the ozone lamp is caliorated each time an audit is periormed.

The conversion efficiency of the $\mathrm{NO}_{2}$ converter in the $\mathrm{NO}_{\mathrm{NO}}$ enalyzer is audited during the gas phase titration procecure. The conversion efiticiency (CE) is calculated by means of the eçuation:

$$
C E=100 \times\left[1-\left(\frac{\Delta C_{i 0}}{\Delta C_{N 0}}\right)\right]
$$

where $\Delta C_{N O}$ and $\Delta C_{N O}$ are the chenges (decreases) in concentrations of $N O$ and $\mathrm{NO}_{x}$ which are ooserved during the titration. In calculating $\Delta C_{N O}$ and $\Delta C_{N O}$ due allowance is made for the dilution sfiect of the adced ozone straym. If there is no change in the $N_{x}$ concentration, then the $C \equiv$ is $100:$. If the $C \equiv$ is below $\leqq 0_{0}^{\alpha}$, the converter is probably in need of rapair. 
D. Carbon Monoxide (CO)

The CO standards are cylinders containing 1000-2500 ppm co in nitrogen. Cylinders are analyzed at the AMC by direct one-to-one comparison with an SRM cylinder obtained from NES and containing approximately the same concentration of CO. The analysis is similar to that described for NO, except that a CO analyzer (Bendix NDIR) is used for the comparison.

\section{E. Hydrocarbons}

The hydrocarbon standards are cylinders containing aperoximately 1000 pem $\mathrm{CH}_{4}$ in air. Cyinders are analyzed at the AuC by direct comparison with a cylincer containing approximately the same concentration of $\mathrm{CH}_{4}$. The latter cylinder was analyzec for $\mathrm{CH}_{4}$ by NeS. The enalysis is cone using an FIO gas chrometograph and measuring peak arsas. Gas samples are injectad undilutad by means of a gas sampling valve.

\section{F. Sulfur Dioxide $\left(\mathrm{SO}_{2}\right)$}

The $\mathrm{SO}_{2}$ standards are permeation tube devices. Nomally $\mathrm{SO}_{2}$ pemeation tubes are 2 or 50 SRM tubes obtained from NBS. During the audit tubes are Taintained at $30.0 \pm 0.1^{\circ} \mathrm{C}$ in the calibritor oven. The permeation rata is given by WSS. Occasionally when auditing an analyzer which is operated in a high $\mathrm{SO}_{2}$ range (grazter than $1 \mathrm{pmm}$ ), longer permeation suces cotained From Metronics Copporation are used. These latter uubes are calibrated at the AMC by comparison with an SAM tube using an $\mathrm{SO}_{2}$ analyzer.

\section{Laboratory Check of the Portable Audit Device}

The portable audit device is checked at the ith prior to and at the conciusion of each trip. The test inciudes a multipoint flow calibration check of the tiro flow controllers to essure that the calibration charts (standard flow vs. voltaç) have not chanced by more than l\%. A full Feriomence test is tien performed as toliows. An enalyzer is first calibrated at a single point to detemine its sensitivity (in pom/volt). For this curpose a iixed lacoratory calibrator is used. The analyzer is 
then calibrated again in an independent fashion using the portable audit cevice. The anaiyzer sensitivity obtained with the portable audit device is comparsd to that obtained with the iixed calisrator. Ideally, the ratio should be 1.00. Sensitivity checks are made for $\mathrm{NO}_{2} \mathrm{NO}_{2}, \mathrm{O}_{3}$ and $\mathrm{SO}_{2}$. In this way all functional components of the audit device are checked. Since the object of the creck is to evaluate the periomance of the audit device, the same 110 gas cylinder and $\mathrm{SO}_{2}$ permeation tubes are used with the fixed calibrator and with the portable audit device.

The fixed latoratory calibrator is intended to be the primary calibration source. It is functionaliy similar to the portalis audit devica, except that it is pemanently attached to a laboratory bench and its major use is for checking the portabie device. Since the laboratory calibrator is not cesigned for field use, several changes were made to optimize reiliability and acauracy. Thus the mixing chambers and connecting tubing are constructed of pyrax glass using a minimum of demountabie joints, and pyrex and Teiton manual stopcocks are used in place of electrical solenoid valves. To attain more precisa temperature control, permeation tube hoiders are imersed in a constant temcerature water bath rather than in an air oven.

Since two independently calibrated flow esntrollers are invoived in each device, the maximum expected discrepancy between the two sensitivity deteminaticns is 4.\%. The portable aucit device is judged to be in good order if the ratio of sensitivities detamined by using the tiwo devicas (i.e., the portabie audit device and the fixed calibrator) is between 0.96 and 1.04. Usualiy the observed ratio of sensitivities is between 0.98 and 1.02. A fauty solenoid valve, a leak in the system, contanination in the iines, a bad flowmetar calibration, or any other concaivable fillure mode wculd be expected to cause the experimentaily detemined sensitivity ratio to deviate significantiy from 1.00 , end corrective action would then ce necessary. 
Table 1 A shows the latest available audit devica operational checks periomed immediately before and after this audit. Sensitivities are given in $\mathrm{pem} / \mathrm{volt}$. Because the laboratory analyzers are used for laboratory testing and not for monitoring purposes, they are not maintained in calibration. Occasionally different analyzers are used in the before and aiter test. Thus one should compare the constancy in the ratio of sensitivities before and after the audit rather than the constancy in the sensitivities themseives.

\section{AUDIT PROCEDURE}

The audit procedure consists of celivering to each analyzer itive difierent concentrations, including zero, using the portable audit device. The output of the analyzer is read out with the measuring instrument which is romally in use at the station. The read-out device is eitice a strip chart recorder, a data logger, a mini-computer, or a digital voltmeter, and the output parameter is either the number of strip chart divisions, percent deilection, digital vol tage, or ppm concentration. The result of the audit is in Effect a E-point calibration which is compared with the latest station calibration by one or more methods, as described bejow. When differences are unusualiy large, an attempt is made to iocate the sourca of the problem.

Deta Analysis

There are at least two ways in which audit results and station calibration data can be treated to cbtain a useiul measurs of agresment between the two. Most agencies record thair calibration data as a table or a graph which relates the input concentration to some arbitrary output parameter (mv, vclis, : chart, chart divisions, etc.). The relationship is described by an equation of the form $C=A+B X$, where $C$ is the concentration in pom, $x$ is the analyzer outzut parameter, and $A$ and $B$ are constants abtained by linear regreszicn anaiysis. ine equation is subsaquentiy used to calculate ambient concantrations from rezsurad outputs. 
TABLE IA

CALIBRATOR OPERATIONAL CHECK ${ }^{*}$

(Sensitivity in ppm/volt)

\begin{tabular}{|c|c|c|c|c|c|c|}
\hline Channel & $\begin{array}{c}\text { Fixed } \\
F \\
\end{array}$ & $\begin{array}{c}\text { 10-2-7 } \\
\text { (before } \\
\text { Portable } \\
\text { P }\end{array}$ & $\begin{array}{l}78 \\
\text { audit) } \\
\text { Ratio } \\
P / F \\
\end{array}$ & $\begin{array}{c}\text { Fixed } \\
F \\
\end{array}$ & $\begin{array}{c}\text { lafter } \\
\text { Portable } \\
P \\
\end{array}$ & $\begin{array}{l}\text { t) } \\
\text { Ratio } \\
P / F \\
\end{array}$ \\
\hline NO & 0.566 & 0.581 & 1.027 & 0.575 & 0.503 & 0.977 \\
\hline $\mathrm{NO}_{2}$ & 0.385 & 0.382 & 0.992 & 0.526 & 0.575 & 0.979 \\
\hline $\mathrm{C}_{3}$ & 0.472 & 0.492 & 1.042 & 0.548 & 0.544 & 0.993 \\
\hline $\mathrm{SO}_{2}$ & 0.932 & 0.907 & 0.973 & & & \\
\hline
\end{tabular}

* Aucit device No. 1 , colloquially known as Bessie. 
The audit data is described by an equation similar to that developed for the station calibration. The rost direct comparison between the tivo sets of data is to show graphicaliy the two straight lines on the same $C$ vs $X$ graph. Difierences between the station calibration and audit results are evaluated by comparinc inear regression constants directly or, more conveniently, by calculating percent difference in $C$ at full scale, as shown in equation $A-1$.

$\therefore$ Difference $=100 \times \frac{\text { (Station oom at full scale) }- \text { (Audit pon at full scale) }}{\text { (Audit ppm at fuli scale) }}$

The comparison procedures outlined above have in fact been used for most of the audits conducted since the beginning of the program unti? June, 1978. These procedures have the advantage that: both calibration and audit data are fully displayed, and any deficiencies regarding cailbration range, number of calibration points, instrumental sensitivity, precision, or non-linear response become readily apparent. The major disadvantage of the method is that comparison of calibration constants among different instruments and agencies is difficult because the magnitude of $B$ depends on the units of the output parameter.

In order to achieve uniformity in the way audit results are reported, a second method has been adopted for audits conducted after June, 1973. The method is to compare the concentrations delivered to the analyzer irom the audit device to those predicted by the station calibration equation. In a few agencies a station computer displays concentration directly rather than the analyzer output voltage, and for these agencies the second method of data analysis has been used previousiy. The audit report shows a graph of station concentration ( $y$-axis) versus audit concentration ( $x$-axis) as well as a table of the slope and intercept of the graph for each channei tested. Mathematicaliy the results are expressed by equation A-2

$$
C_{2}=a+B C_{1},
$$

where $C_{2}$ is the station concentration, $C_{1}$ is the audit concentration, $z$ is the slope, and $a$ is the intercapt. Perfect agreement between station and audit is represented in each graph by the dotted "unity line" $3=1, a=0$. 
The advantage of the second method is that $B$ is non-dimensional, and its value is independent of the analyzer range and the units used to express analyzer output. The magnitude of 8 is a useful measure of relative agreement between the station calibration and the audit results, as discussed below. Also the results of different audits can ce readily compared. Of course, details of the station calibration are not shown.

The percent difference between station and audit concentrations can be readily expressed in tems of the magnitude of a and $\beta$, as shown in equation A-3

$$
: \text { Difference }=100 \times \frac{C_{2}-C_{1}}{C_{1}}=100\left[(3-1) \div \frac{a}{C_{1}}\right]
$$

Since nomally the magnitude of $\frac{a}{C_{j}}$ is small compared to $B-1$, the percent difierence is a constant representad by the quantity 100 (3-1). It is this latter relationship that makes a a useful comparison parameter.

There are tivo casas where the persent difierence is not detemined primarily by the value of $B$, and these are, of course, cases where the intercept $a$ is large, or the audit concentration $C_{\eta}$ is very small. For these two cases the percent difference is not a constant, and its value depends on $\mathrm{C}_{1}$. In order to give a complete picture of the agency performance, audit reports sho' values of a and $z$ for the latest audit. A sumary page is also included listing the current and $a 1$ ? pravious values of $B$.

The two methods described in this appendix appear to give difierent measures of comparison between station calibrations and audit results. Appendix 8 demonstratas that the tiwo methods are in fact equivalent.

\section{Fieid Audit of Hign Voiume Samolers}

The high volume sampler flow raze is measured using a calibrated orifice plate (Sierra instruments) and a watar manometer. The ambient temperature and Fressure at the tine of the audit are aiso measured by Rockivell using a caibrated themometer and pressure transducer. Unilke the hi-vol interiaboratory performance survey audits, a field audit is a single point check of 
the flow rate in use at the site. At the same time that Rockwell measures the pressure drop across the orifice, the agency detemines the flow according to its normal operating procedures. Since there is ro uniformity among agencies in the way high volume flow is reported, the comparison between the audit measurement and the station calibration is made at the flow conditions specified by the agency or at EPA standard conditions. Typically iiow rates are reported at one of the following conditions: a) EPA standard conditions (298\% $\mathrm{K}, 760 \mathrm{~mm} \mathrm{Hg})$, (b) ambient temperature and pressure at the time of tbe measurement, (c) ambient laboratory conditions at the time of the original sensor calioration, or (d) unspecified (this occurs, for exampie, if the agency usas a fixed chart to convert from sensor reading to fiow rate without any corractions for tamperature or pressure).

The rathematics used to calculate Rockweil's audit flow at the desired flow conditions is outlined below.

The flow rate through the orifice plate is initially calioratad in the Rockwell laboratory using a 3 M 125 CTR HI-HOL calibration meter (Rocts-ifeter). The flow rate is given by the equation $Q_{1}=A \div B \sqrt{\Delta P}$, where $Q_{1}$ is the amoient flow in cubic meters per minute (CMM) caiculated at the Rockueli iaboratory conditions during calibration, $\Delta P$ is the pressure drop at the orifice plate in inches of water, and $A$ and 3 are empirically detemined inear regrassion coeficients. The conversion of laboratory conditions to actual field conditions during the audit is obtained by means of the aquation

$$
Q_{2}=Q_{1}\left(\frac{P_{1}}{P_{2}} \times \frac{T_{2}}{T_{1}}\right)^{\overline{72^{2}}} \text {, where }
$$

$Q_{2}=$ ambient Fow rate calculated at iieid conditions

$P_{2}=$ ambient pressure in the field during audit (nm of Hg)

$T_{2}=$ anbient temperature in the field during audit (0k)

$P_{i}=$ pressure in the Rockwell latoratory during calitration of orifice (mm Hg)

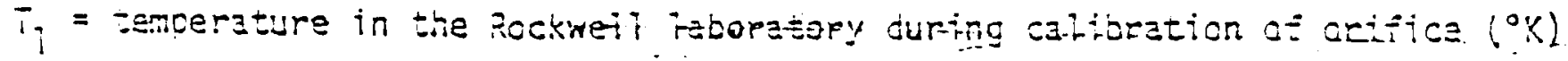


To convert $Q_{2}$ to standard conditions, the following equation is used

$$
Q_{S T O}=Q_{2}: \frac{P_{2}}{750} \times \frac{298}{T_{2}}
$$

To convert $Q_{2}$ to any other specified temperatura $T_{c}$ and pressure $P_{c}$, the following equation is used

$$
Q_{c}=Q_{2} \times \frac{P_{2}}{P_{c}} \times \frac{T_{c}}{T_{2}} .
$$

\section{EVALUATION CRITERIA}

Each instrument audit results in a comparison between the station cal ibration and the audit results. Nomally the enalyzer rasponse is linear. in scme cases, where single point checks are made (e.g., high volume sampier), the response is assumed to be linear. Usually, but not always, the differanca in the zero concentration output measured during station calibration and during the audit is negligibly small, and difierences betiesn the station calibration and audit results cause the graph of $C_{2} v s C_{1}$ to have a slope difierent from one. In these cases, the value of 100 (s-l) gives the percent difierence between the station and audit concentrations for ail values of $C$. If deviations from linearity or zero difierences are cbsarved, they ara specificaliy mentioned in the text.

Criteria for evaluating difierances between station and aucit concentrations are not rigidly defined and obviously have not been established. The definition for what constitutes satisfactory or unsatisfactory agreement is necessarily arbitrary and depends on the intended use of the data.

For the purposes of these audits, we offer the following working guideline, subject to revision or refinement:

Ditiarencas of 10\% or less require no specific corrective action, and may be considered satisiaczory. 
Differences in excess of $10 \%$ are of irmediate concern. In such cases, Rockivell ilill make a specific attempt to locate the source of the problem, and if this is not practical, likaly scurces of error will be identified and recommendations will be made to the agencies for further study. (A typical recormendation of this type is to request the agency to recalibrate (or calibrate for the first time) the station calibrator.) 


\section{APFENDIX B}

Appendix A describes two methods for reporting audit resuits. This appendix shows how the $A$ and $B$ parameters in the first method are related to the $a$ and $B$ parameters of the second method.

In the first method concentration and analyzer output are described by equations $B-1$ and $B-2$

$$
C_{1}=A_{1}+B_{1} \times \text {, }
$$

and

$$
C_{2}=A_{2}+B_{2} \times \text {. }
$$

In these equations the subscript 7 refers to the audit results, and the subscript 2 refers to the station calibration. For a given analyzer cutput $x$ the relationsinip between $C_{1}$ and $C_{2}$ is obtained by eliminating $x$ from the two equations. The result is given by equation $B-3$

$$
\bar{C}_{2}=\frac{B_{2}}{B_{1}} C_{1}+\left(A_{2}-\frac{B_{2}}{B_{T}} A_{T}\right)
$$

Comparing equation B-3 with equation A-2 it can be clearly seen that

$$
\begin{gathered}
B=\frac{B_{2}}{B_{1}} \\
\alpha=A_{2}-\frac{B_{2}}{B_{1}} A_{1}
\end{gathered}
$$

Equations $B-4$ and $B-5$ show that $\alpha$ and $B$ are readily derived from values of $A$ and $B$. 
It is interesting to compare percent difference at full scale (equation $A-1$ ) with the percent difference as expressed by equation $A-3$. Re-writing equation $A-1$ in terms of the $A$ and $B$ constants results in equation $B-6$

$$
\therefore \text { Diff }=100 x \frac{\left(B_{2}-B_{1}\right) x+\left(A_{2}-A_{1}\right)}{B_{1} x+A_{1}}
$$

Equation B-6 shows that percent difference is 3 function of $X$ and hence $X$ is nomally specified at full scale. Since usually the $A$ term is sinall compared to $B X$, for sufficientiy large $X$ the percent difierence becomes independent of $x$ and reduces to the constant expression

$$
\approx \text { Diff } \cong 100 \times \frac{B_{2}-B_{1}}{B_{1}}=100(8-1)
$$

Thus within the approximation that intercepts are small, the percent difference at full scale and the quantity $100(B-i)$ give similar results. 
APPENDIX C

This appendix describes a third way in which audit results may be used to assess the accuracy of the monitoring data. The method involves the calculation of the average percent difference between $C_{1}$ and $C_{2}$. The procedure is fully described in the EPA quality assurance requirements guideline for PSD air monitoring (Federal Register August 7, 1978 Part II) and is as follows:

Let $x_{i}$ represent the known concentration $c_{1}$ in the audit gas for $i^{\text {th }}$ audit point, and $Y_{i}$ represent the concentration $C_{2}$ measured by the station. Assume $n$ audit points (usually 4 span points plus zero). Calculate the percentage difference $\left(d_{j}\right)$ for each audit point using equation ?:

$$
d_{i}=\frac{\gamma_{i}-x_{i}}{x_{i}} \times 100
$$

For each instrument or instrument channel, caiculate the average percentage deviation $\left(\bar{a}_{j}\right)$ using equation 2 and the standard deviation $\left(S_{j}\right)$ by means of equation 3 :

$$
\begin{gathered}
\bar{d}_{j}=\sum_{i=1}^{n} d_{i} / n \\
s_{j}=\left[\frac{\sum_{i=1}^{n} d_{i}^{2}-\left(\sum_{i=1}^{n} d_{i}\right)^{2} / n}{n-1}\right]^{1 / 2}
\end{gathered}
$$

The 95 percent probability limits for data accuracy are then calculated from Equations 4 and 5 :

$$
\begin{aligned}
& \text { Upper } 95 \text { Percent Probability Limit: } \bar{d}_{j}+1.96 \mathrm{~s}_{j} \\
& \text { Lower } 95 \text { Percent Probability Limit: } \bar{d}_{j}-1.96 \mathrm{~s}_{j}
\end{aligned}
$$


The above set of calculations is used for a single analyzer or analyzer channel in any one given station. In order to arrive at a measure of overall agency accuracy for a given species, the average of averages is calculated by means of equation 6 , using results of instruments within the agency for a single pollutant:

$$
\bar{D}=\sum_{j=1}^{k} \bar{d}_{j} / k
$$

where

$\vec{D}$ is the average of averages, $k$ is the number of instruments audited for any given pollutant species.

The agency standard deviation is calculated by means of equation 3 , except that $\mathrm{n}$ is the total number of audit points for all instrunents for any given pollutant.

The 95 percent probability limits for agency accuracy are calculated using equations similar to 4 and $\overline{5}$, except that $\bar{D}$ and $S_{a}$ are used in place of $\bar{d}_{j}$ and $s_{j}$. 
APPENDIX B

FIELD EXPERIENCE WITH AMBIENT LEVEL

FLAME PHOTOMETRIC SULFUR DETECTORS 
FIELD EXPERIENCE WITH

AMBIENT LEVEL FLAME PHOTOMETRIC SULFUR DETECTORS

D. Weber ${ }^{\Delta}$, K. B. $01 \operatorname{sen}^{\dagger}$ and J. D. Ludwick*

$\triangle$ United States Environmental Protection Agency, 200 S.W. 35th St., Corvall is OR 97330

*+ Pacific Northwest Laboratory

Richland, WA 99352

\section{ABSTRACT}

Personnel respiration produces increased levels of carbon dioxide within field monitoring trailers. These levels were found sufficient to produce serious calibration errors in the flame photometric detector when measuring ambient concentrations of gaseous sulfur products. Quantitative measurement of the carbon dioxide interference in the sulfur emission is reported as well as a method of estimating the extent of quenching agent poliution. 


\section{FIELD EXPERIENCE WITH}

AMBIENT LEVEL FLAME PHOTOMETRIC SULFUR DETECTORS

D. Weber, K. B. 01 sen and J. D. Ludwick

A field program is in progress in Montana conducted by the Environmental Protection Agency (EPA) to identify and quantitate the environmental impact of coal-fired power plants. To this end, a portion of the effort is devoted to air quality monitoring and sampling several miles downwind from the Colstrip power plants $\# 1$ and $\# 2$ in a rather remote area of the state. Four such stations with varying degrees of sophistication have been established in the most prevalent downwind direction of air mass flow. These are located in semi-arid rangeland with access limited, by and large, to 4-wheel drive vehicies. Each site basically consists of a small trailer which serves to provide shelter and a controlled environment for the housed instruments. Three of the sites are completely self-contained, generating and regulating their own power systems. Among other instrumentation, each site is equipped with a sulfur analyzer for continuous monitoring of the atmosphere. At the present time, they are alt flame photometric devices (FRD). The prasent report covers experiments conducted at our major monitoring location (Hay Coulee). Here we have had experience with several manufacturers' instruments as well as various analytical monitoring techniques for atmospheric sulfur analysis. 
. 
In a major effort to upgrade the accuracy of the data being collected under sponsorship of the EPA, an independent contractor (Rockwell International) has been assigned the task of quality assurance. On a routine schedule this agent of EPA inspects and tests all equipment utilized for data collection on programs operated by or for this Federal agency. The results from these routine audits are used to suggest methods of improving accuracy and defining the limits of error for a historical batch of data. In general, this program has been very useful in upgrading the quality of the air sampling and monitoring data throughout the agency. Responsibility for operation of the Colstrip, Montana stations was assigned to the Authors during the past year. Unexplained differences in the calibration of the sulfur instrumentation have been documented between the Rockwell audits and those conducted routinely at the sites by the authors. Each group, presumably, utilized standard NBS or NBS traceable permeation tube calibration sources and other accepted dilution techniques. This paper is a report of the cause of these errors, their magnitude, conditions conducive to their occurrence as well as their elimination.

Extensive use has been made of the flame spectrometric method for the analysis of sulfur containing compounds. $(1,2)$ This technique gives rise to the light from the excited $S_{2}$ band in a hydrogen-rich flame. The emission is dependent to 
a great degree on the nature and temperature of the flame. Precise gas metering and mixing makes high accuracy and reproducibility attainable. The effect of other gaseous substances on the molecular emission of the $S_{2}$ species has been reported. $(3,4)$ It was found that the presence of other gaseous organic compounds in the carrier gas used to transfer sulfur compounds into the flame detector led to a decrease in response when compared with that observed in their absence. The intensity of the sulfur emission was diminished by the presence of hydrocarbons, alcohols and carbon dioxide. Selected cases were examined and it was found that the interference with the molecular emission caused by organic compounds depends on the concentration of these organic materials. The decrease in the emission for two concentrations of sulfur containing material with increasing organic concentrations in the carrier gas was found to be similar in several cases. (5)

At our primary monitoring site, it was noted from time to time, that unexplained differences in the position of zero would occur when utilizing the internal trailer air as the carrier gas in spite of the gas cleanup system. These differences were not constant from day to day. Small zero shift effects which may not have been observed or considered important by other workers were critical to the integrity of our monitoring data since all values measured in the clean 
environment were below $50 \mathrm{ppb}$. For this reason we made it a practice to always use outside ambient air as the primary source of zero air after passing it through appropriate cleanup beds. At the time of the last audit we noted that inside air was used as the carrier gas before presenting the unknown sulfur dioxide concentrations to our instrumentation for verification. It seemed reasonable to assume that concentrations of interfering materials which were not scrubbed from the carrier gas might be causing these discrepancies. Although environmental control of temperature is maintained within the trailers for the instrumentation, no provision was made for outside air ventillation. In fact, some effort was made, in the past, to reduce such interchange due to the harsh climate. The most obvious possibility for flame interference was increased concentrations of $\mathrm{CO}_{2}$ gas from personnel respiration. If this was found to be significant in the instrumental range of concern, one could readily envision the probable effects from extra personnel during audit days (3-4 aduits).

\section{EXPERIMENTAL}

To examine and quantitate the effects of $\mathrm{CO}_{2}$ concentration changes in the carrier gas on sulfur response, an experimental arrangement for gas mixture control was built. This consisted of a supply of pure $\mathrm{CO}_{2}$ gas fed into a double dilution air system. The dilution air was cleansed with ascarite to remove $\mathrm{CO}_{2}$. 
Standardized air concentrations of $\mathrm{CO}_{2}$ could then be prepared including the range typical of normal air. This mixture was purified over silica gel and charcoal before entering an $\mathrm{SO}_{2}$ permeation system with traceability to NBS calibration. The response to changing mixtures of $\mathrm{SO}_{2}$ and $\mathrm{CO}_{2}$ were measured in a standard FPD sulfur analyzer. ${ }^{(a)}$ This instrument was initially calibrated using normal outside air and a $\mathrm{SO}_{2}$ permeation tube. In this manner, deviations in $\mathrm{SO}_{2}$ response due to changing $\mathrm{CO}_{2}$ concentrations could be observed and related to auditing difficulties. Four concentrations of $\mathrm{SO}_{2}$ gas were used in the range between 20-100 ppb. At each of these concentrations, the sulfur emission intensity was observed in the presence of 4 standard carbon dioxide carrier gas mixtures and normal outside air. The ranges of these mixtures were chosen to encompass $\mathrm{CO}_{2}$ concentrations to be anticipated by workers under similar confined situations. Another series of similar experiments were conducted with a second ambient air monitor. $(b)$ Both of these monitors were utilized on this project for sulfur analysis. DISCUSSION

A composite of the results from carbon dioxide interference in the sulfur emission is shown in Figure 1. Also included for comparison is carrier air whose $\mathrm{CO}_{2}$ concentration was that produced during a typical day with two adult workers inside the trailer. It is apparent that the slopes of these curves are essentially constant. That is, the interference with the emission is independent of the

(a) Meloy Laboratories Model SA 160 Ambient Sulfur Analyzer (b) Meloy Laboratories Model 285E Ambient Sulfur Analyzer. 
concentration of the sulfur dioxide. This is in agreement with Sugiyama et al. for other quenching agents.

A plot of the instrumental response to low concentrations of $\mathrm{SO}_{2}$ in the presence of varying $\mathrm{CO}_{2}$ levels is shown in Figure 2. Extrapolation of the instrumental output to higher concentrations of carbon dioxide illustrate the complete remission of sulfur response at about $3000 \mathrm{ppm}$. The slopes of the curves are a function of the $\mathrm{SO}_{2}$ concentrations while the intercept is essentially independent of these low $\mathrm{SO}_{2}$ levels. Figure 3 is a curve generated by loglog regression analysis, illustrating the empirical relationship between changing instrumental response and changing interference levels. The slope of the carbon dioxide to response curve may be expressed as a function of the $\mathrm{SO}_{2}$ levels,

$$
\frac{\Delta \ln \left[\mathrm{CO}_{2}\right]}{\Delta \text { response }}=f\left[\mathrm{SO}_{2}\right]
$$

where the $\left[\mathrm{CO}_{2}\right]$ and $\left[\mathrm{SO}_{2}\right]$ are expressed in ppm and $\mathrm{ppb}$ respectively.

The curve suggests the variance in $\mathrm{SO}_{2}$ may be represented as:

$$
f\left(\mathrm{SO}_{2}\right)=k\left[\mathrm{SO}_{2}\right]^{x}
$$

and, therefore, the change in instrumental output is,

$$
\Delta \text { response }=\frac{\Delta \mathrm{In}\left[\mathrm{CO}_{2}\right]}{k\left[\mathrm{SO}_{2}\right]^{\mathrm{x}}}
$$


$K$ and $x$ were evaluated from this curve and found to be -140.62 and -1.9643 respectively. Then,

$\Delta$ response $=$

$$
\underline{\ln \left[\mathrm{CO}_{2}\right]_{\text {fina }]}-\ln \left[\mathrm{CO}_{2}\right]_{\text {initial }}\left[\mathrm{SO}_{2}\right]^{1.9643}}
$$

$-140.62$

The instrumental response can then be predicted from anticipated carbon dioxide level changes and observations of standard condition situations with formula (4). Using the response changes from Figure 1 for any concentration of sulfur dioxide and substituting into equation (4) we can also calculate the level of $\mathrm{CO}_{2}$ present when the trailer contained two occupants. This was found to be $750 \mathrm{ppm}$.

Other estimates can be made of the anticipated carbon dioxide concentration within the instrumented trailer from personnel occupancy. The respiratory rate for a man in light activity is about 1200 liters/hr, with an oxygen to carbon dioxide conversion of about $4 \% .6$ The net carbon dioxide input is, therefore, 48 liters $\mathrm{CO}_{2} /$ man-hr and thus 96 liters $\mathrm{CO}_{2} / 2$ man-hr. Our trailer volume is approximately 40,000 liters of which 13.2 liters is $\mathrm{CO}_{2}$ under standard conditions. Assuming that sufficient time had elapsed 
for $\mathrm{CO}_{2}$ equilibrium to exist, then the value of $750 \mathrm{ppm}$ measured represents the resultant input from two men occupants. This net carbon dioxide gain of 17 liters/hr is the result of the production rate (96 liters/hr), less the trailer loss rate. The rate of carbon dioxide loss is, therefore, 79 liters/hr. If we assume that complete mixing occurs between incoming air containing $330 \mathrm{ppm}$ and outgoing polluted air, then some 2.7 air changes occur per hour within the trailer. Less complete mixing would allow the observed carbon dioxide concentrations with less air turnover. From this, estimates of the carbon dioxide concentrations expected from additional personnel occupancy can be made. From the rate of personnel respiration, it is apparent that without some ventillation the $8-\mathrm{hr}$ exposure limit of $5000 \mathrm{ppm}$ (American Institute of Industrial Hygiene) could be exceeded within the trailer during an 8-hour day.

Experimental results from testing of the second instrumental type were sufficiently different from the first to be of interest. In this case, lower interference levels were observed in the presence of $\mathrm{CO}_{2}$; however, certain peculiarities were manifest. Figure 4 illustrates the change in sulfur response with varying $\mathrm{CO}_{2}$ concentrations. Both positive and negative effects were observed in the presence of elevated $\mathrm{CO}_{2}$ levels when compared with instruments calibrated to operate in air containing ambient $\mathrm{CO}_{2}$ concentrations. The synergistic effect of positive sulfur response coupled with both positive and/or negative $\mathrm{CO}_{2}$ effects served to produce an anomalous correct response in the region of about $30 \mathrm{ppb}$. Above that point, increasing concentrations of $\mathrm{CO}_{2}$ serve to provide more quenching of the sulfur 
emission. This is in agreement with the observations in our first case study. Below this point, unexpected positive instrumental responses correlating with increasing $\mathrm{CO}_{2}$ concentrations were noted.

Obviously, analysts must be on guard concerning the possibility for carbon dioxide or other organic material buildup in their.carrier air. This can result not only from personnel respiration, but from many other sources including natural abberations (swamps, biota), anthropogenic (downwind stack measurements), fire and others. It is important either to be aware of the changing interfering components present or to make measurements after calibrating in their immediate presence. 


\section{REFERENCES}

1. Crider, W. L. Ana1. Chem. 37:1770-73, 1965.

2. Brody, S. S. and J. E. Chaney. J. Gas Chromatog. 4:42-46, 1966.

3. Rupprecht, W. E. and T. R. Phillips. Ana1. Chim. Acta. 47:439-49, 1969.

4. Perry, S. G. and F.W. G. Carter. Proceedings of the 8th International Gas Chromatography Symposium, Dublin 1970, pp. 381-398.

5. Sugiymama, Toshiaki, Yoshihito Suzuki and Tsugio Takeuchi. J. Chromatography. 80:61-67, 1973.

6. Inhalation Risks from Radioactive Contamination. Technical Report Series No. 142, Internationa 7 ATomic Energy Agency, Vienna, 1973, p. 30. 

FIGURE 1

LOW-LEVEL SULFUR EMISSION QUENCHING BY $\mathrm{CO}_{2}$

FIGURE 2

EFFECT OF $\mathrm{CO}_{2}$ ON FPD RESPONSE TO VARYING $\left[\mathrm{SO}_{2}\right]$

FIGURE 3

RELATIONSHIP BETWEEN CHANGING CONCENTRATIONS

OF $\mathrm{CO}_{2}$ FOR LOW-LEVEL SULFUR EMISSION

FIGURE 4

INTERFERING EFFECTS OF $\mathrm{CO}_{2}$ ON THE $\mathrm{SO}_{2}$ RESPONSE

OF A MELOY 285E AMBIENT SULFUR ANAL YZER

CREDIT

This work was performed for the U.S. Environmental Protection Agency under

Interagency Agreement EPA-IAG-D7-0473 


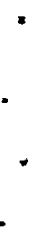




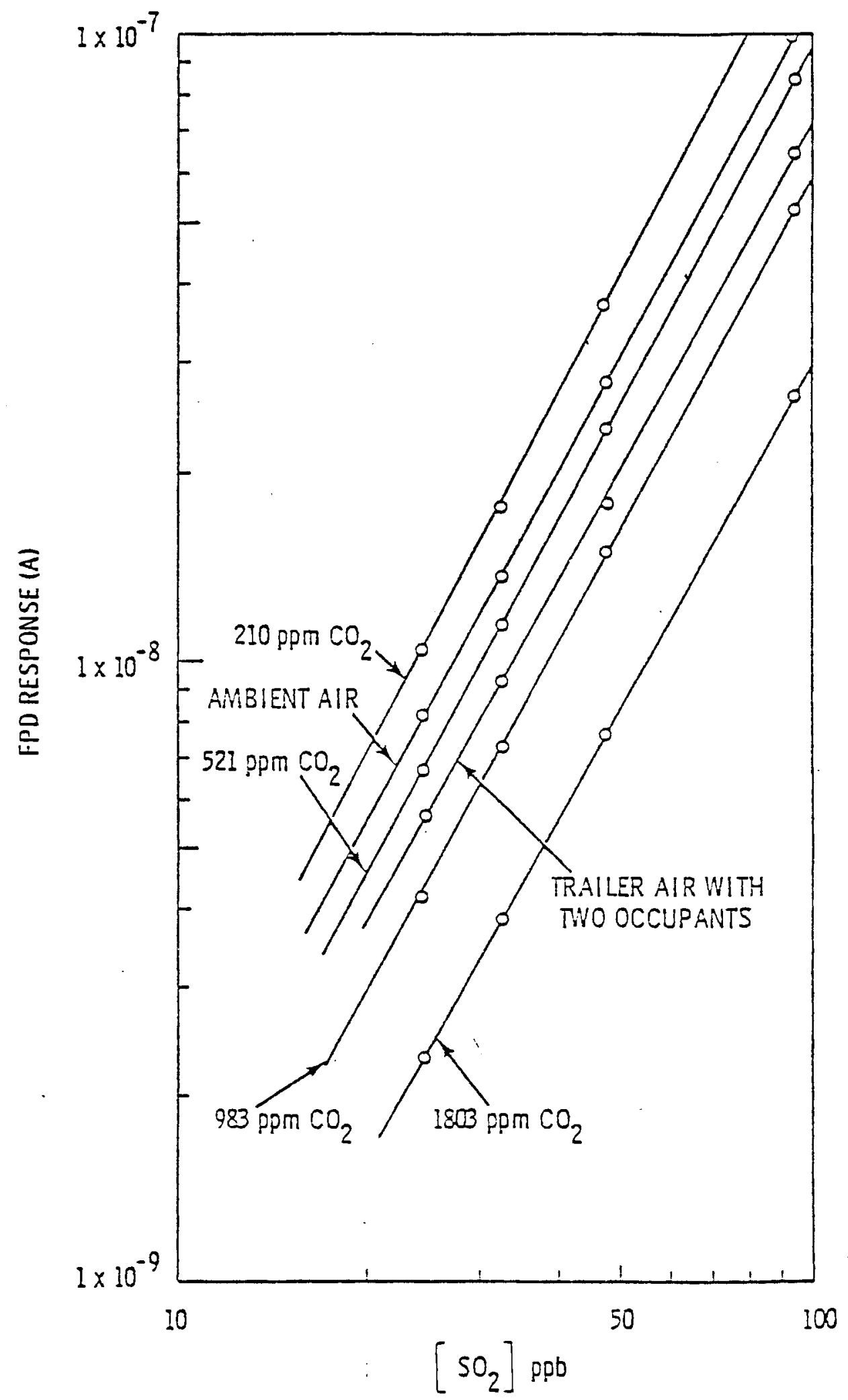

FIGURE 1. Low-Level SuTfur Emission Quenching by $\mathrm{CO}_{2}$ 


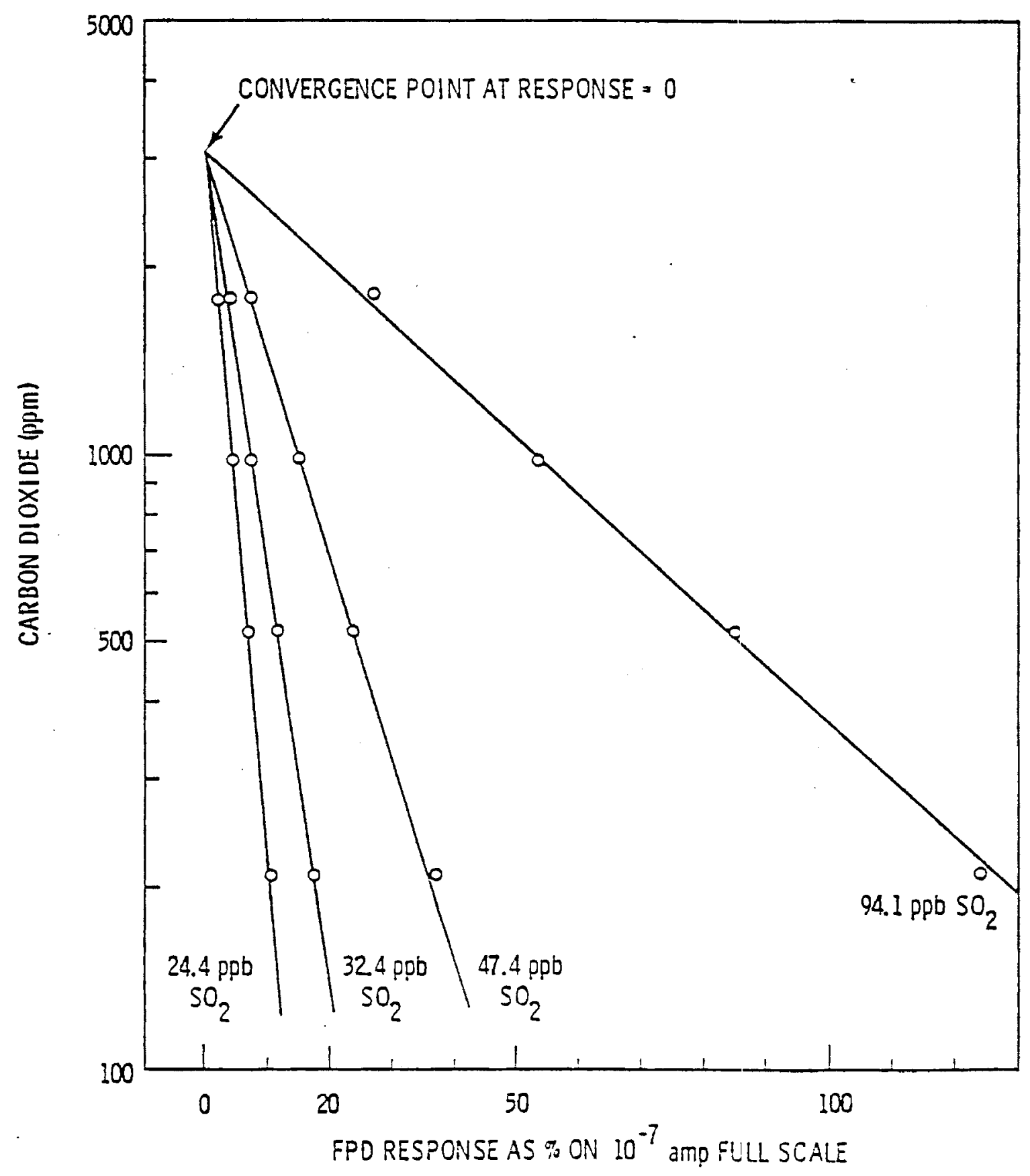

FIGURE 2. Effect of $\mathrm{CO}_{2}$ on FPD Response to Varying $\left[\mathrm{SO}_{2}\right]$ 


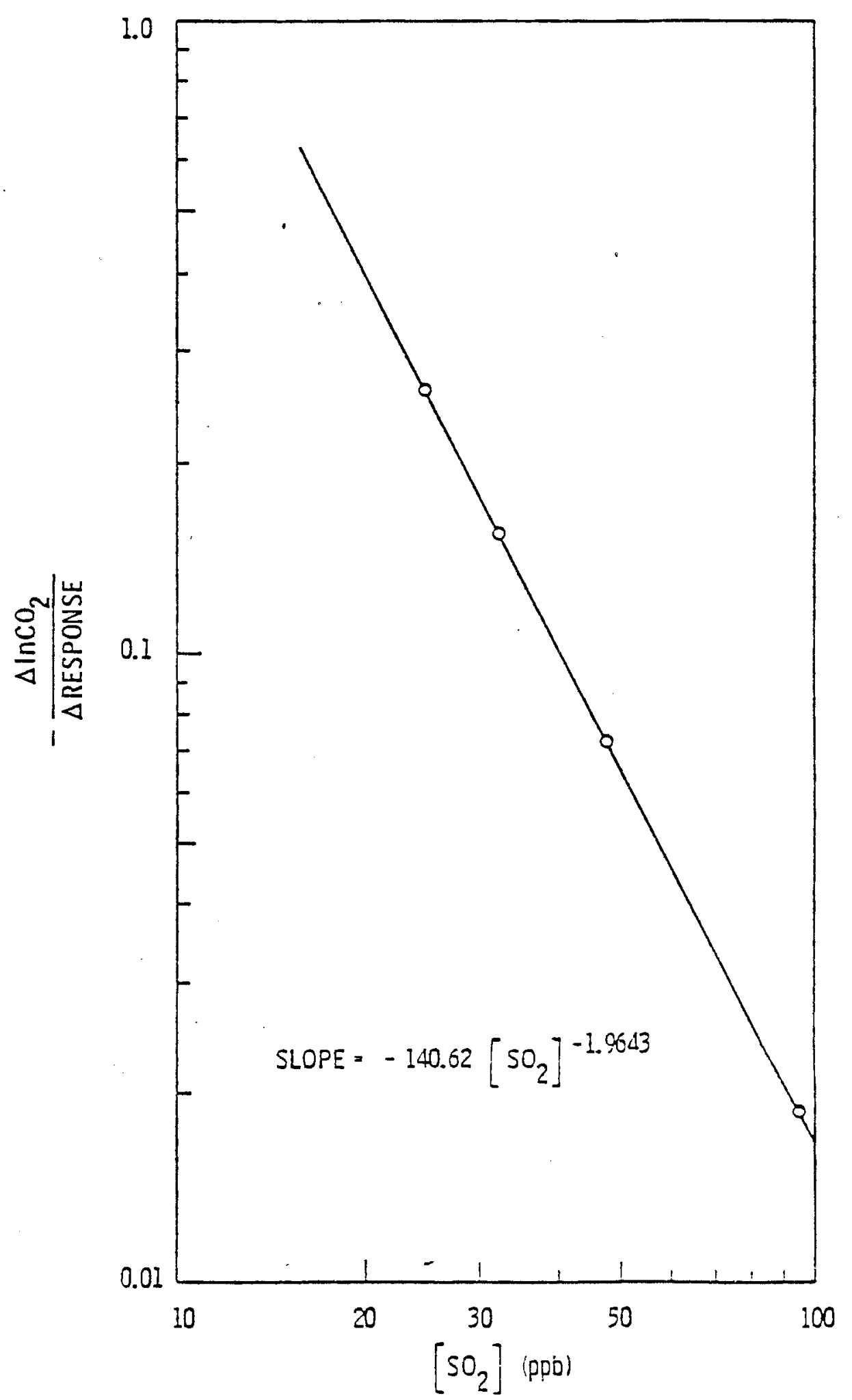

FIGURE 3. Relationship Between Changing Concentrations of $\mathrm{CO}_{2}$ for Low-Level Sulfur Emission 


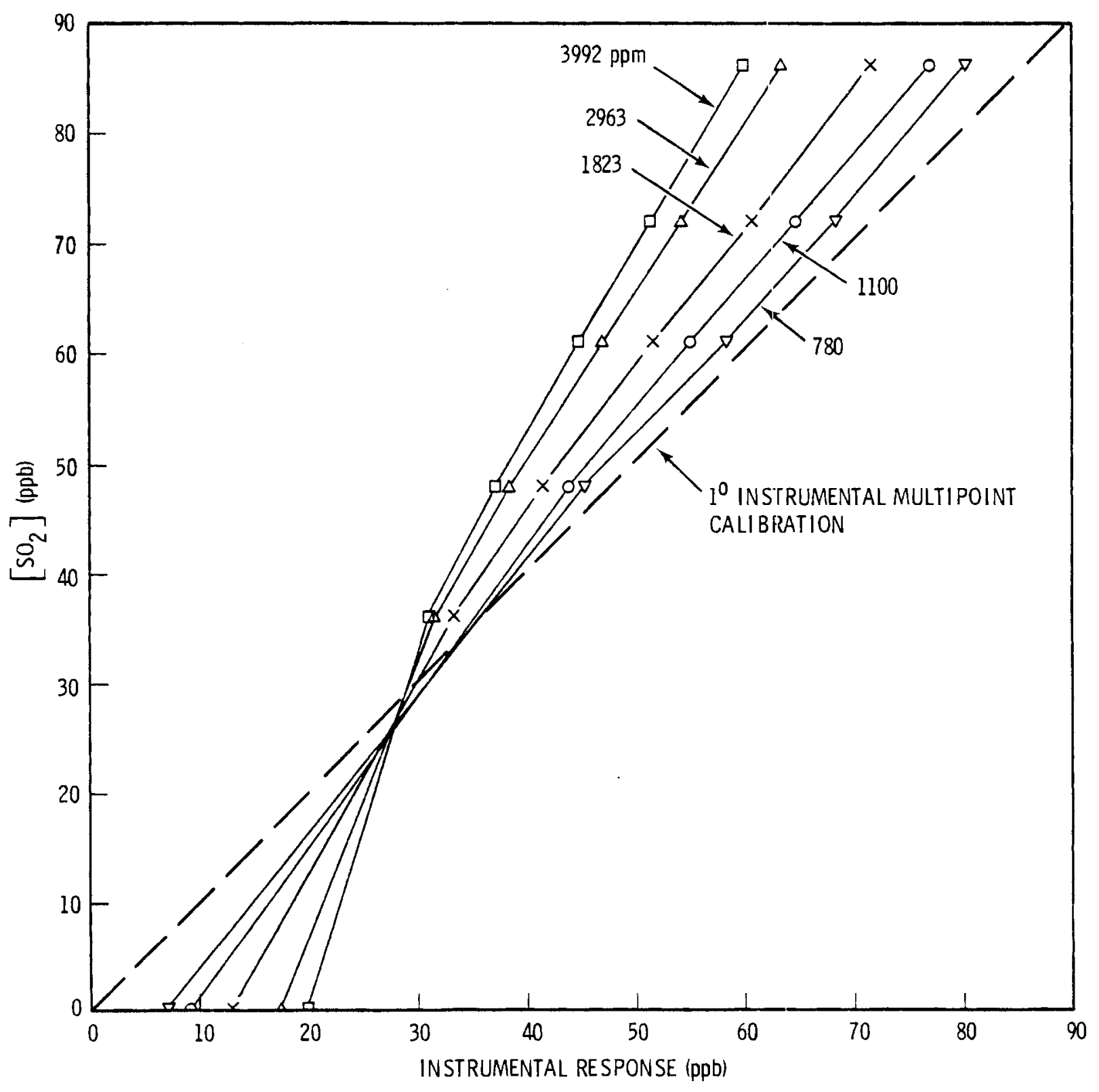

FIGURE 4. Interfering Effects of $\mathrm{CO}_{2}$ on the $\mathrm{SO}_{2}$ Response of a Meloy $285 E$ Ambient Sulfur Analyzer 
APPENDIX C

POWER PLANT DATA 
TABLE C.1. The Relative Influence of $\mathrm{SO}_{2}$ Powerplant

Emissions at Downwind Monitoring Stations

\begin{tabular}{|c|c|c|c|c|c|c|c|c|c|}
\hline & \multicolumn{2}{|c|}{ TONS SO$_{2}$ INPUT $^{*}$} & \multicolumn{2}{|c|}{ TONS $\mathrm{SO}_{2}$ OUTPUT ** } & \multirow{2}{*}{$\begin{array}{l}\text { TOTAL } \\
\text { OUTPUT }\end{array}$} & \multicolumn{4}{|c|}{$\begin{array}{l}\text { FRACTION OF WIND: STATION ORIENTED } \\
\text { RELATIVE } \mathrm{SO}_{2} \text { INFLUENCE (tons) }\end{array}$} \\
\hline & UNIT I & UNIT II & UNITI & UNIT II & & HAY COULEE & $\mathrm{KW}$ & $\mathrm{KE}$ & BNW-1 \\
\hline JANUARY & 1700 & 971 & 287 & 225 & 512 & $\cdots$ & -- & -- & $\cdots$ \\
\hline FEBRUARY & 1620 & 1384 & 170 & 284 & 454 & $\begin{array}{l}0.146 \\
(66)\end{array}$ & -- & --- & --- \\
\hline MARCH & 1997 & 1120 & 281 & 161 & 442 & $\begin{array}{l}0.243 \\
(102)\end{array}$ & $\begin{array}{l}0.447 \\
(198)\end{array}$ & $\begin{array}{l}0.160 \\
(71)\end{array}$ & --- \\
\hline APRIL & 1330 & 138 & 310 & 32 & 342 & $\begin{array}{l}0.294 \\
(101)\end{array}$ & $\begin{array}{l}0.370 \\
(127)\end{array}$ & $\begin{array}{l}0.269 \\
(92)\end{array}$ & -- \\
\hline MAY & 33 & 1872 & l & 223 & 224 & $\begin{array}{l}0.331 \\
(74)\end{array}$ & $\begin{array}{l}0.368 \\
(82)\end{array}$ & $\begin{array}{l}0.204 \\
(46)\end{array}$ & --- \\
\hline JUNE & 1073 & 1594 & 211 & 349 & 560 & $\begin{array}{l}0.241 \\
(135)\end{array}$ & $\begin{array}{l}0.442 \\
(248)\end{array}$ & $\begin{array}{l}0.246 \\
(138)\end{array}$ & -- \\
\hline JULY & 1156 & 1283 & 214 & 217 & 431 & $\begin{array}{l}0.303 \\
(131)\end{array}$ & $\begin{array}{l}0.178 \\
(77)\end{array}$ & $\begin{array}{l}0.186 \\
(80)\end{array}$ & -- \\
\hline AUGUST & 1592 & 1528 & 255 & 319 & 574 & $\begin{array}{l}0.243 \\
(139)\end{array}$ & -- & $\begin{array}{l}0.204 \\
(117)\end{array}$ & --- \\
\hline SEPTEMBER & 1390 & 1269 & 205 & 240 & 445 & $\begin{array}{l}0.198 \\
(88)\end{array}$ & -- & $\begin{array}{l}0.184 \\
(82)\end{array}$ & $\begin{array}{l}0.329 \\
(146)\end{array}$ \\
\hline OCTOBER & 1584 & 1569 & 261 & 311 & 572 & $\begin{array}{l}0.291 \\
(166)\end{array}$ & -.- & $\begin{array}{l}0.295 \\
(169)\end{array}$ & $\begin{array}{l}0.388 \\
(222)\end{array}$ \\
\hline NOVEMBER & 1493 & 1633 & 280 & 334 & 614 & $\begin{array}{l}0.170 \\
(104)\end{array}$ & --- & --- & $\begin{array}{l}0.304 \\
(185)\end{array}$ \\
\hline DECEMBER & 1756 & 1947 & 260 & 281 & 541 & $\begin{array}{l}0.166 \\
(90)\end{array}$ & -.- & $\cdots$ & $\begin{array}{l}0.348 \\
(188)\end{array}$ \\
\hline
\end{tabular}


TABLE C.2.A. Colstrip Unit \#1 Emission Data (January 1978)

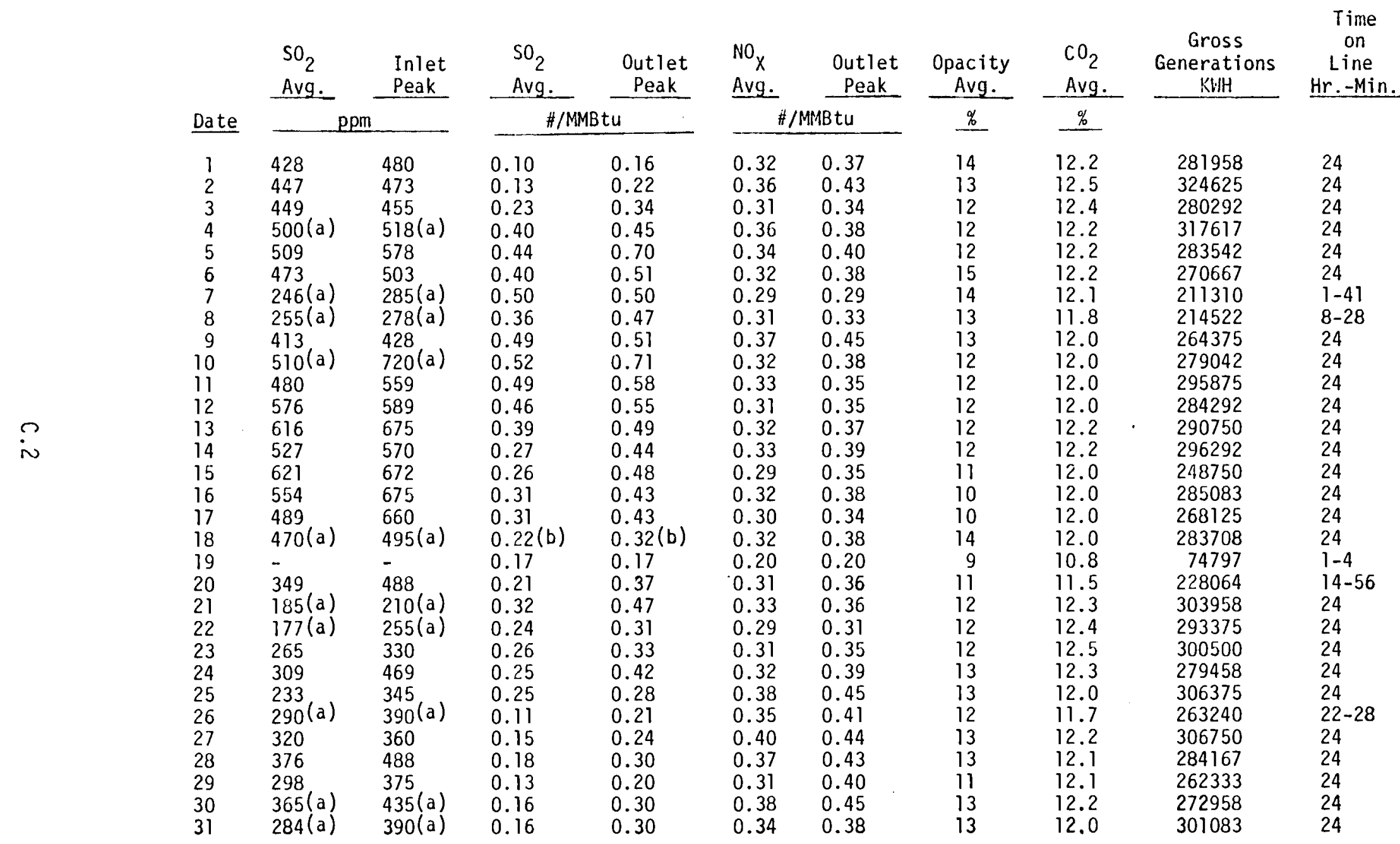

(a) Data from one inlet monitor only.

(b) Data from outlet monitors.

Dashed indicate no data due to monitor malfunctions.

Coal Consumption: $126,836.4$ tons

Coal Analysis: $0.70 \% \mathrm{~S}$

Scrubber Availability: $95.7 \%$

Total Time on Line: $672 \mathrm{hr}, 47 \mathrm{~min}$. 
TABLE C.2.B. Colstrip Unit \#2 Emission Data (January 1978)

\begin{tabular}{|c|c|c|c|c|c|c|c|c|c|c|}
\hline & $\begin{array}{l}\mathrm{SO}_{2} \\
\text { Avg. } \\
\end{array}$ & $\begin{array}{l}\text { Inlet } \\
\text { Peak }\end{array}$ & $\begin{array}{l}\mathrm{SO}_{2} \\
\mathrm{Avg}\end{array}$ & $\begin{array}{c}\text { Outlet } \\
\text { Peak } \\
\end{array}$ & $\begin{array}{l}{ }^{N O} \mathrm{x} \\
\text { Avg. }\end{array}$ & $\begin{array}{c}\text { Outlet } \\
\text { Peak } \\
\end{array}$ & $\begin{array}{c}\text { Opacity } \\
\text { Avg. } \\
\end{array}$ & $\begin{array}{l}\mathrm{CO}_{2} \\
\text { Avg. }\end{array}$ & $\begin{array}{c}\text { Gross } \\
\text { Generations } \\
\text { KWH } \\
\end{array}$ & $\begin{array}{c}\text { Tille } \\
\text { on } \\
\text { Line } \\
\text { Hr.-Min. }\end{array}$ \\
\hline Date & & & & \#/MMB tu & & & $\%$ & $\%$ & & \\
\hline $\begin{array}{l}1 \\
2 \\
3 \\
4 \\
5 \\
6 \\
7 \\
8 \\
9 \\
10 \\
11 \\
12 \\
13 \\
14 \\
15 \\
16 \\
17 \\
18 \\
13 \\
20 \\
21 \\
22 \\
23 \\
24 \\
25 \\
26 \\
27 \\
28 \\
29 \\
30 \\
31\end{array}$ & $\begin{array}{l}406 \\
387 \\
404 \\
200(\mathrm{a}) \\
0 \\
0 \\
0 \\
0 \\
0 \\
0 \\
0 \\
0 \\
0 \\
0 \\
207 \\
361 \\
414 \\
418 \\
387 \\
409 \\
412 \\
0 \\
445 \\
415 \\
361 \\
238 \\
275 \\
290 \\
309 \\
339 \\
285(\mathrm{a})\end{array}$ & $\begin{array}{l}428 \\
405 \\
439 \\
360(a) \\
0 \\
0 \\
0 \\
0 \\
0 \\
0 \\
0 \\
0 \\
0 \\
0 \\
225 \\
450 \\
473 \\
434 \\
503 \\
465 \\
488 \\
0 \\
585 \\
439 \\
488 \\
353 \\
345 \\
330 \\
394 \\
390 \\
300(a)\end{array}$ & $\begin{array}{l}0.36 \\
0.35 \\
0.38 \\
0.19 \\
0 \\
0 \\
0 \\
0 \\
0 \\
\text { Unit } \\
0 \\
0 \\
0 \\
0.13 \\
0.40 \\
0.44 \\
0.37 \\
0.33 \\
0.35 \\
0.36 \\
0.38 \\
\text { Unit } \\
0.34 \\
0.40 \\
0.32 \\
0.30 \\
0.29 \\
0.34 \\
0.30 \\
0.34 \\
0.28\end{array}$ & $\begin{array}{c}0.43 \\
0.43 \\
0.44 \\
0.19 \\
0 \\
0 \\
0 \\
0 \\
0 \\
\text { Off Line } \\
0 \\
0 \\
0 \\
0.24 \\
0.65 \\
0.49 \\
0.43 \\
0.43 \\
0.52 \\
0.54 \\
0.46 \\
\text { Off Line } \\
0.44 \\
0.44 \\
0.42 \\
0.36 \\
0.39 \\
0.47 \\
0.50 \\
0.45 \\
0.42\end{array}$ & $\begin{array}{l}0.48 \\
0.39 \\
0.45 \\
0.18 \\
0 \\
0 \\
0 \\
0 \\
0 \\
0 \\
0 \\
0 \\
0 \\
0.29 \\
0.38 \\
0.37 \\
0.39 \\
0.51 \\
0.40 \\
0.43 \\
0.42 \\
0 \\
0.37 \\
0.44 \\
0.44 \\
0.45 \\
0.39 \\
0.51 \\
0.41 \\
0.42 \\
0.47\end{array}$ & $\begin{array}{l}0.51 \\
0.46 \\
0.48 \\
0.18 \\
0 \\
0 \\
0 \\
0 \\
0 \\
0 \\
0 \\
0 \\
0 \\
0.35 \\
0.44 \\
0.44 \\
0.41 \\
0.52 \\
0.44 \\
0.49 \\
0.50 \\
0 \\
0.43 \\
0.47 \\
0.46 \\
0.48 \\
0.44 \\
0.55 \\
0.48 \\
0.48 \\
0.52\end{array}$ & $\begin{array}{l}13 \\
14 \\
13 \\
10 \\
0 \\
0 \\
0 \\
0 \\
0 \\
0 \\
0 \\
0 \\
0 \\
12 \\
11 \\
11 \\
12 \\
12 \\
12 \\
13 \\
14 \\
0 \\
11 \\
13 \\
12 \\
14 \\
13 \\
16 \\
14 \\
14 \\
15\end{array}$ & $\begin{array}{l}11.2 \\
11.8 \\
11.5 \\
12.5(b) \\
0 \\
0 \\
0 \\
0 \\
0 \\
0 \\
0 \\
0 \\
0 \\
12.5 \\
12.5 \\
12.5 \\
12.5 \\
12.5 \\
12.5 \\
12.5 \\
12.5 \\
0 \\
12.5 \\
12.5 \\
12.5 \\
12.5 \\
12.5 \\
12.5 \\
12.5 \\
12.5 \\
12.5\end{array}$ & $\begin{array}{l}337500 \\
314417 \\
328250 \\
161085 \\
0 \\
0 \\
0 \\
0 \\
0 \\
0 \\
0 \\
0 \\
0 \\
123929 \\
228333 \\
237293 \\
272625 \\
237667 \\
277292 \\
276250 \\
274372 \\
0 \\
245291 \\
324917 \\
305708 \\
314417 \\
253815 \\
326583 \\
279708 \\
318500 \\
280792\end{array}$ & $\begin{array}{l}24 \\
24 \\
24 \\
3-04 \\
0 \\
0 \\
0 \\
0 \\
0 \\
0 \\
0 \\
0 \\
0 \\
0 \\
3-50 \\
24 \\
22-59 \\
24 \\
24 \\
24 \\
24 \\
23-53 \\
0 \\
11-41 \\
24 \\
24 \\
24 \\
24 \\
24 \\
24 \\
24 \\
24\end{array}$ \\
\hline
\end{tabular}

(a) Data from one inlet monitor only.

(b) \#/MMBtu values calculated using the design $\mathrm{CO}_{2}$ average of $12.5 \%$ for the duration of the month.

Coal Consumption: $72,300.9$ tons

Coal Analysis: $0.70 \%$ sulfur

Scrubber Availability: $97.3 \%$

Total Time on Line: $449 \mathrm{hr} ., 35 \mathrm{~min}$. 
TABLE C.3.A Colstrip Unit \#1 Emission Data (February 1978)

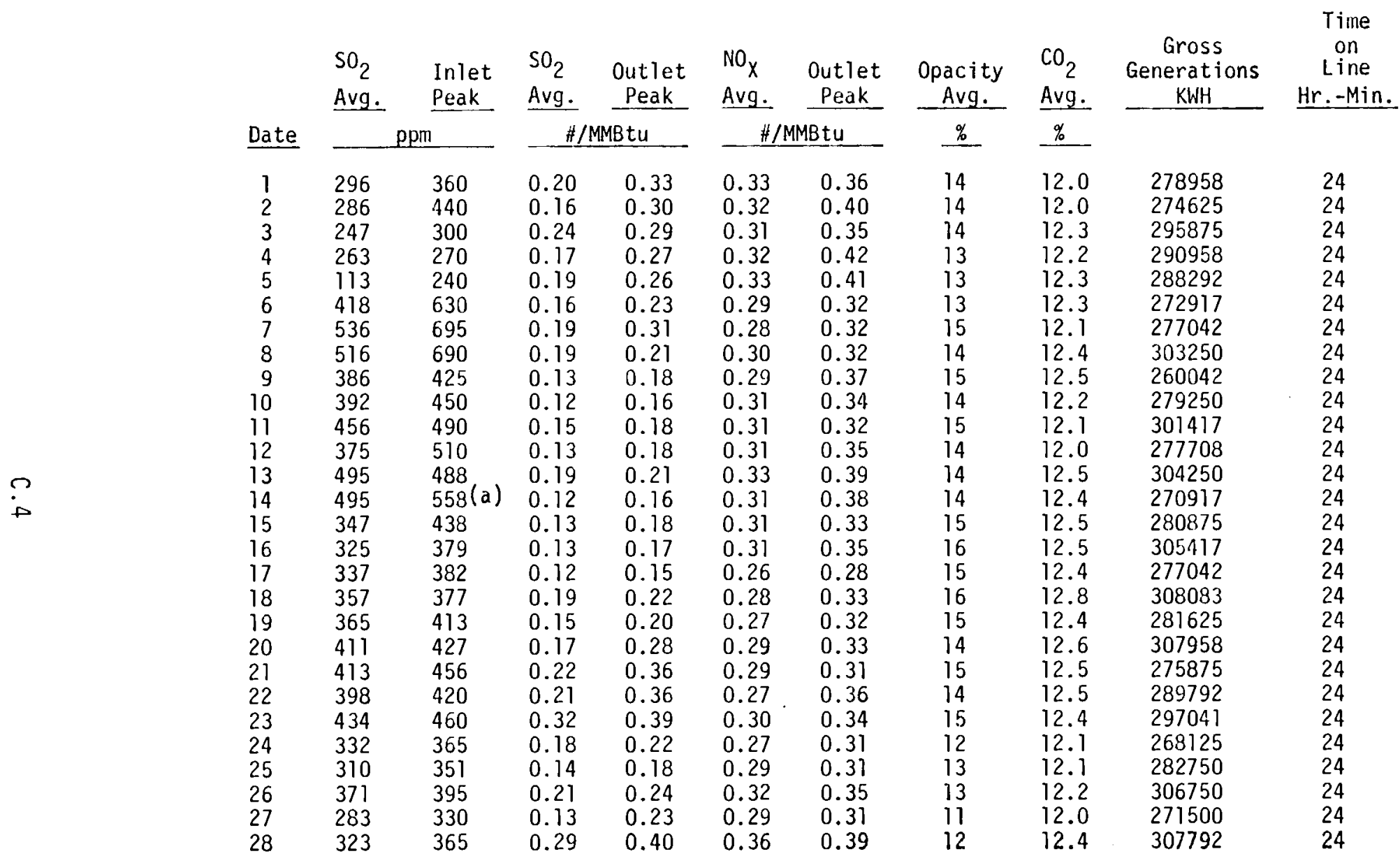

(a) Data from one inlet monitor only.

Coal Consumption: $124,045.0$ tons

Coal Analysis: $0.68 \%$ sulfur

Scrubber Availability: $99.5 \%$

Total Time on Line: $672 \mathrm{hr}$. 
TABLE C.3.B Colstrip Unit \#2 Emission Data (February 1978)

\begin{tabular}{|c|c|c|c|c|c|c|c|c|c|c|}
\hline \multirow[b]{2}{*}{ Date } & $\begin{array}{l}\mathrm{SO}_{2} \\
\text { Avg. }\end{array}$ & $\begin{array}{l}\text { Inlet } \\
\text { Peak }\end{array}$ & $\begin{array}{l}\mathrm{SO}_{2} \\
\mathrm{Avg} . \\
\end{array}$ & $\begin{array}{c}\text { Outlet } \\
\text { Peak }\end{array}$ & $\begin{array}{l}{ }^{N O}{ }_{X} \\
\text { Avg. }\end{array}$ & $\begin{array}{c}\text { Outlet } \\
\text { Peak } \\
\end{array}$ & \multirow{2}{*}{$\begin{array}{c}\text { Opacity } \\
\text { Avg. } \\
\frac{\%}{\%}\end{array}$} & $\begin{array}{l}\mathrm{CO}_{2} \\
\text { Avg. }\end{array}$ & $\begin{array}{c}\text { Gross } \\
\text { Generations } \\
\text { KWH } \\
\end{array}$ & $\begin{array}{c}\text { Time } \\
\text { on } \\
\text { Line } \\
\text { Hr.-Min. }\end{array}$ \\
\hline & \multicolumn{2}{|c|}{ ppm } & \multicolumn{2}{|c|}{ \#/MMBtu } & \multicolumn{2}{|c|}{ \# / MMBtu } & & $\%$ & & \\
\hline 1 & $209(a)$ & $750(a)$ & 0.35 & 0.46 & 0.48 & 0.53 & 15 & $12.5(b)$ & 304167 & 24 \\
\hline 2 & 830 & 965 & 0.33 & 0.53 & 0.42 & 0.52 & 14 & 12.5 & 275000 & 24 \\
\hline 3 & 906 & 915 & 0.41 & 0.51 & 0.45 & 0.48 & 14 & 12.5 & 287500 & 24 \\
\hline 4 & 764 & 965 & 0.27 & 0.31 & 0.35 & 0.43 & 12 & 12.5 & 235125 & 24 \\
\hline 5 & 848 & 1010 & 0.40 & 0.52 & 0.44 & 0.51 & 13 & 12.5 & 308417 & 24 \\
\hline 6 & 752 & 805 & 0.40 & 0.51 & 0.44 & 0.52 & 14 & 12.5 & 298917 & 24 \\
\hline 7 & 751 & 795 & 0.35 & 0.45 & 0.34 & 0.36 & 13 & 12.5 & 22917 & 24 \\
\hline 8 & 664 & 705 & 0.31 & 0.49 & 0.37 & 0.45 & 12 & 12.5 & 218499 & $23-49$ \\
\hline 9 & 0 & 0 & 0 & 0 & 0 & 0 & 0 & 0 & 0 & 0 \\
\hline 10 & 484 & 665 & 0.32 & 0.43 & 0.41 & 0.47 & 15 & 12.5 & 288557 & $20-06$ \\
\hline 11 & 681 & 825 & 0.34 & 0.46 & 0.46 & 0.51 & 14 & 12.5 & 295708 & 24 \\
\hline 12 & 598 & 610 & 0.37 & 0.42 & 0.49 & $0.5 i$ & 16 & 12.5 & 339042 & 24 \\
\hline 13 & 613 & 650 & 0.30 & 0.39 & 0.48 & 0.53 & 17 & 12.5 & 306833 & 24 \\
\hline 14 & 526 & 645 & 0.32 & 0.38 & 0.54 & 0.56 & 17 & 12.5 & 338417 & 24 \\
\hline 15 & 635 & 657 & 0.25 & 0.33 & 0.49 & 0.53 & 18 & 12.5 & 297250 & 24 \\
\hline 16 & 464 & 631 & $0.14(c)$ & $0.24(c)$ & 0.33 & 0.43 & 12 & 12.5 & 115561 & $3-55$ \\
\hline 17 & 566 & 648 & 0.09 & 0.18 & 0.34 & 0.47 & 17 & 12.5 & 232134 & $11-57$ \\
\hline 18 & 613 & 634 & 0.20 & 0.26 & 0.50 & 0.54 & 17 & 12.5 & 329333 & 24 \\
\hline 19 & 610 & $720(a)$ & 0.22 & 0.29 & 0.46 & 0.50 & 18 & 12.5 & $33212-$ & 24 \\
\hline 20 & 624 & $720(\mathrm{a})$ & 0.13 & 0.24 & 0.45 & 0.51 & 17 & 12.5 & 293708 & 24 \\
\hline 21 & 701 (a) & $720(a)$ & 0.19 & 0.26 & 0.44 & 0.47 & 14 & 12.5 & 342458 & 24 \\
\hline 22 & $697(a)$ & $720(a)$ & 0.28 & 0.31 & 0.48 & 0.53 & 15 & 12.5 & 348167 & 24 \\
\hline 23 & 605 & 622 & 0.34 & 0.42 & 0.49 & 0.51 & 14 & 12.5 & 351500 & 24 \\
\hline 24 & 571 & 585 & 0.37 & 0.47 & 0.52 & 0.59 & 15 & 12.5 & 352208 & 24 \\
\hline 25 & 586 & 605 & 0.29 & 0.45 & 0.39 & 0.45 & 15 & 12.5 & 313958 & 24 \\
\hline 26 & 585 & 595 & 0.47 & 0.53 & 0.52 & 0.59 & 16 & 12.5 & 353292 & 24 \\
\hline 27 & 560 & 570 & 0.39 & 0.44 & 0.53 & 0.59 & 15 & 12.5 & 335875 & 24 \\
\hline 28 & 645 & 665 & 0.33 & 0.48 & 0.38 & 0.43 & 16 & 12.5 & 237625 & 24 \\
\hline
\end{tabular}

(a) Data from one inlet monitor only.

(b) \#/MMBtu values calculated using the design $\mathrm{C}_{2}$ average of $12.5 \%$ for the entire month.

(c) Data from outlet monitors only.

Coal Consumption: $106,089.0$ tons

Coal Analysis: $0.68 \%$ sulfur

Scrubber Availability: $94.5 \%$

Total Time on Line: $611 \mathrm{hr} ., 47 \mathrm{~min}$. 
TABLE C.4.A Colstrip Unit \#1 Emission Data (March 1978)

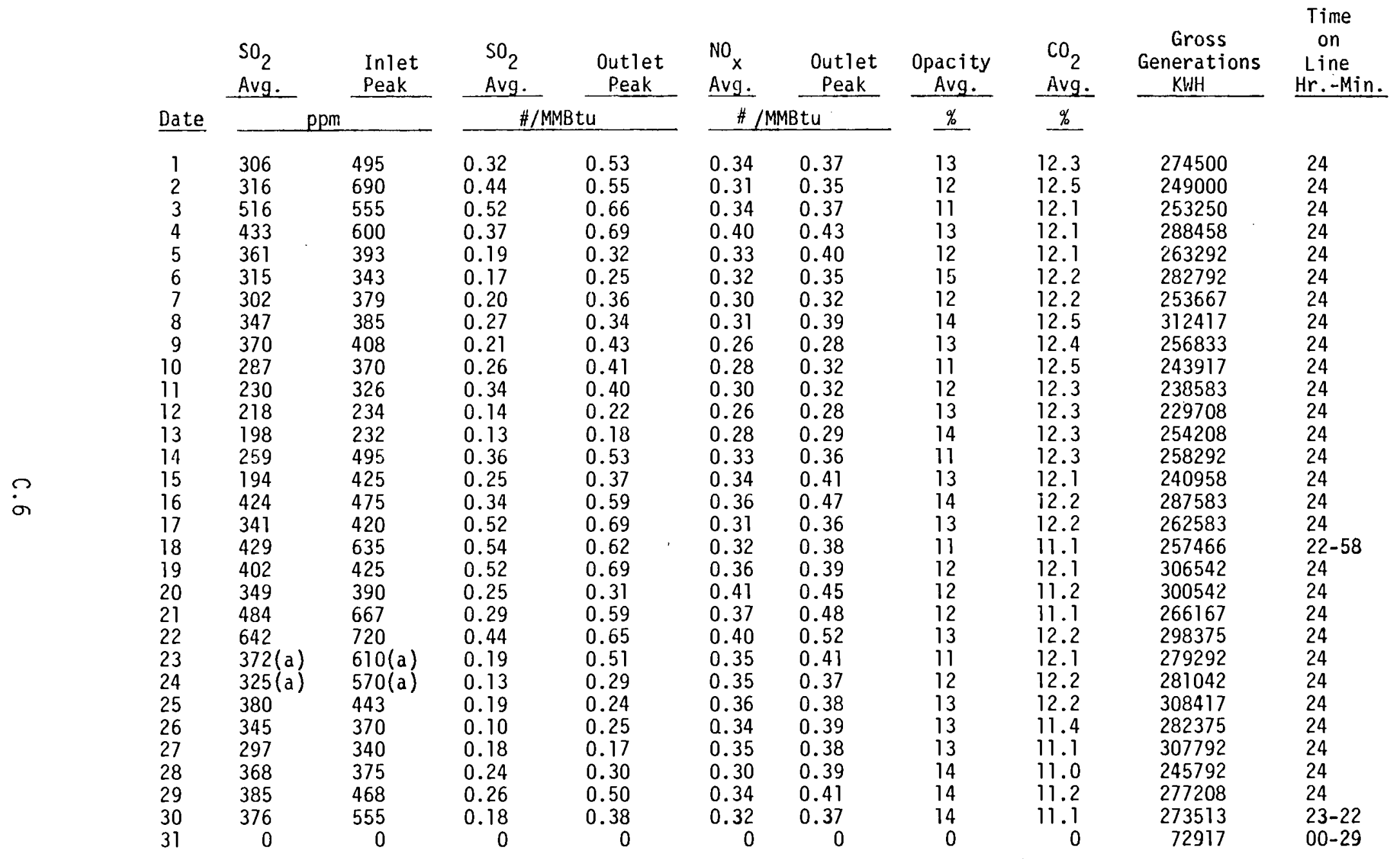

(a) Data from one inlet monitor only.

Coal Consumption: 125,310.3 tons

Scrubber Availability: $92.0 \%$

Coal Analysis: $0.83 \%$ sulfur

Total Time on Line: $718 \mathrm{hr} .49 \mathrm{~min}$.

On March 17, 18 and 19 the $\mathrm{SO}_{2}$ outlet data was taken from the outlet monitors. 
TABLE C.4.B Colstrip Unit \#2 Enission Data (March 1978)

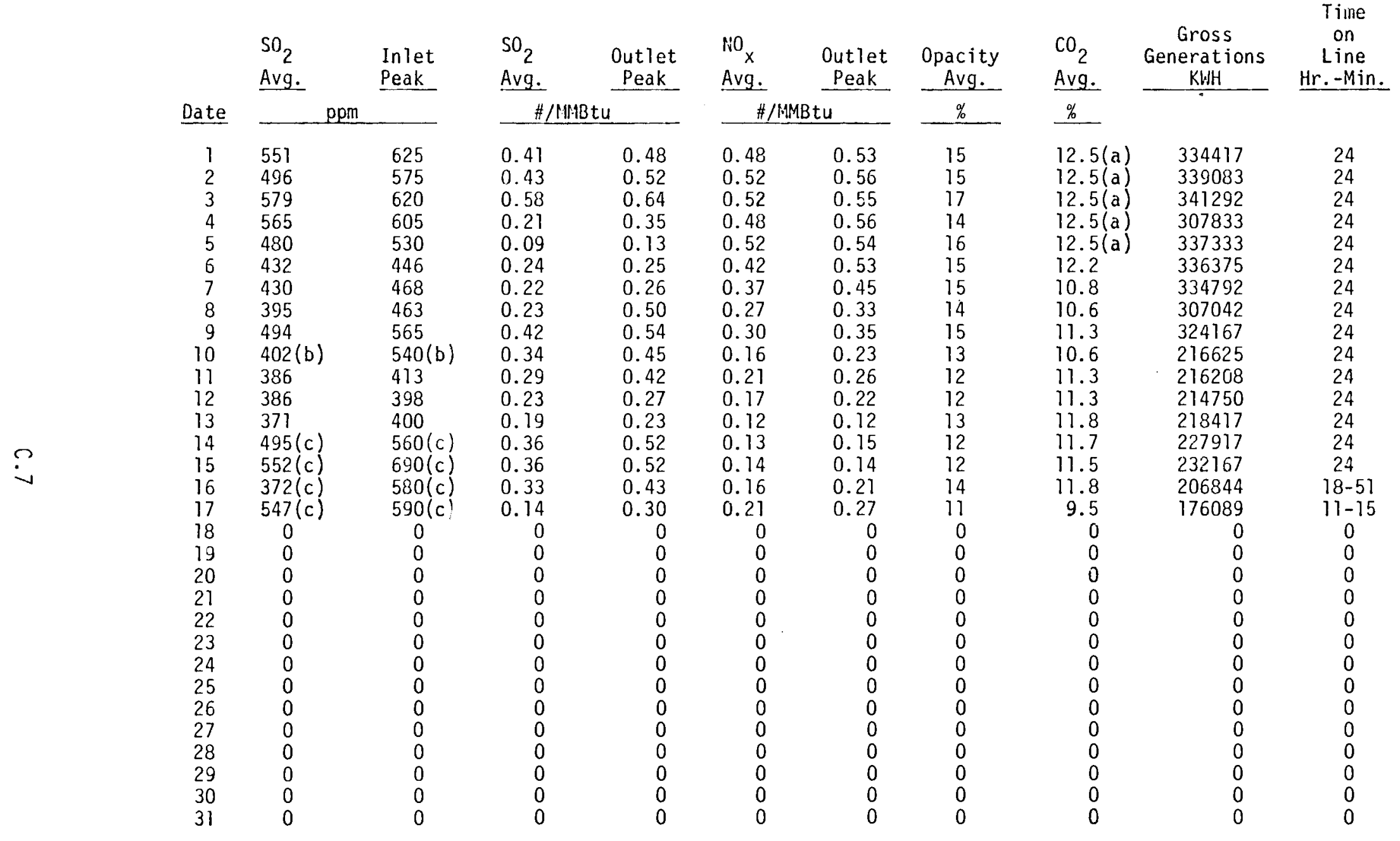

(a) \#/AMBtu values calculated using the design $\mathrm{CO}_{2}$ average of $12.5 \%$.

(b) Data from scrubber log sheets.

(c) Data from one inlet monitor only.

Coal Consumption: $70,210.6$ tons

Scrubber Availability: $89.1 \%$

Coal Analysis: $0.83^{\circ}$ sulfur

Total time on line: $390 \mathrm{hr}$. $06 \mathrm{~min}$. 
TABLE C.5.A Colstrip Unit \#1 Emission Data (April 1978)

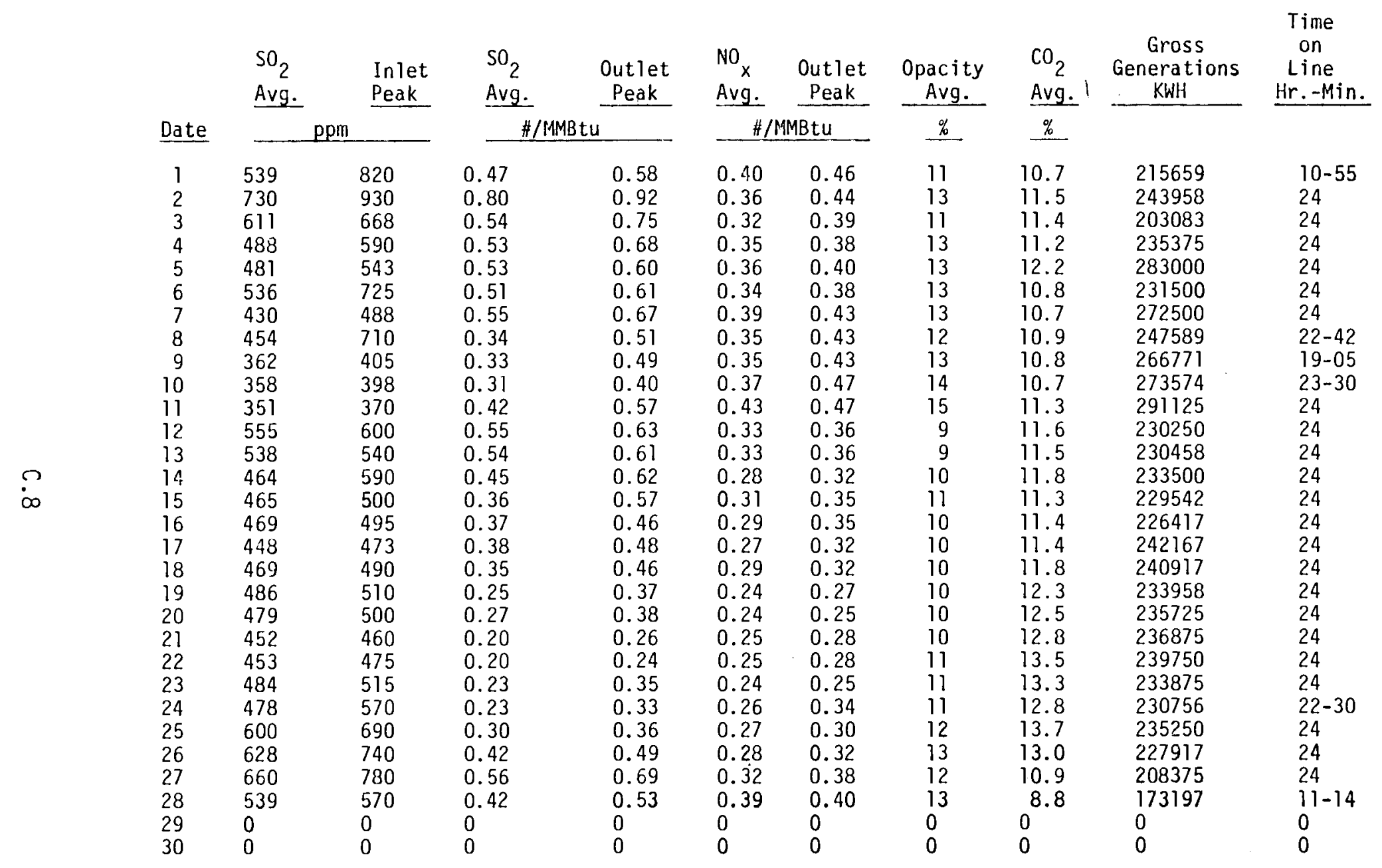

Coal Consumption: 93,595.1 tons

Coal Analysis: $0.74 \mathrm{~T}$ Sulfur

Scrubber Availability: $99.8 \%$

Total Time on Line: $637 \mathrm{hr} ., 56 \mathrm{~min}$. 
TABLE_C.5.B Colstrip Unit \#2 Emission Data (Apri1 1978)

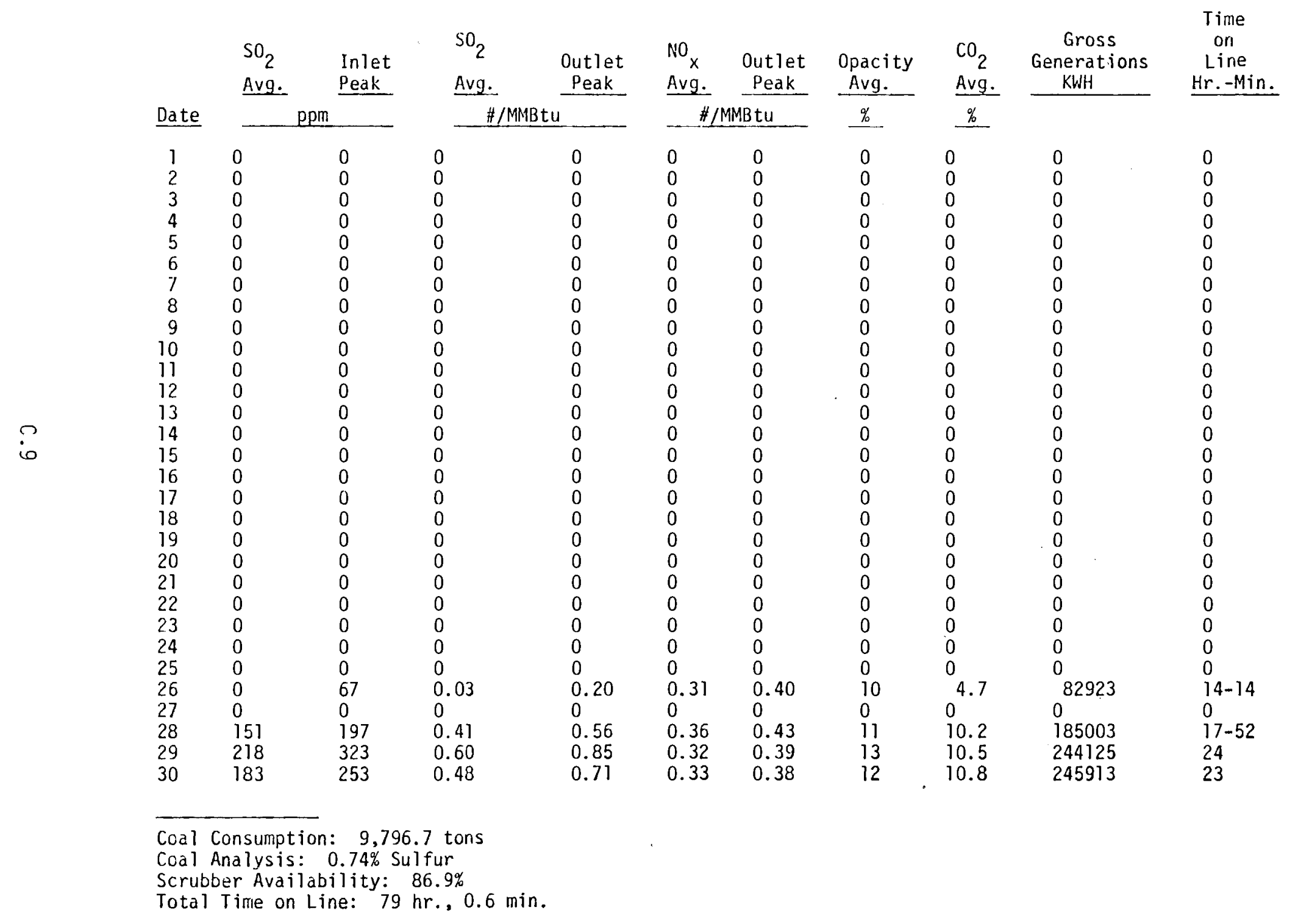


TABLE C.6.A Colstrip Unit \#1 Emission Data (May 1978)

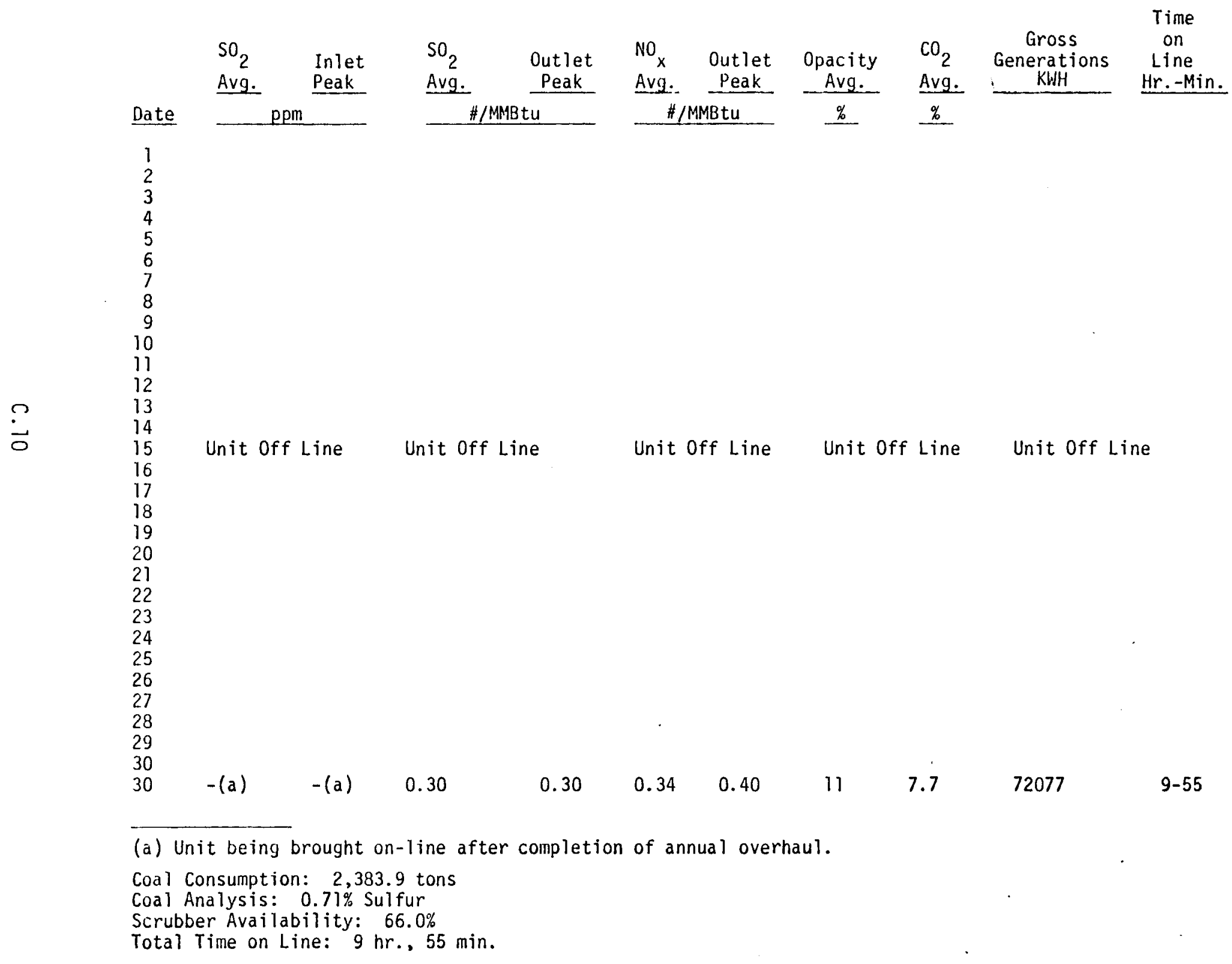


TABLE C.6.B Colstrip Unit \#2 Emission Data (May 1978)

\begin{tabular}{|c|c|c|c|c|c|c|c|c|c|c|c|}
\hline & & $\begin{array}{l}\mathrm{SO}_{2} \\
\text { Avg. } \\
\end{array}$ & $\begin{array}{l}\text { Inlet } \\
\text { Peak }\end{array}$ & $\begin{array}{l}\mathrm{SO}_{2} \\
\text { Avg. } \\
\end{array}$ & $\begin{array}{l}\text { Outlet } \\
\text { Peak } \\
\end{array}$ & $\begin{array}{l}\text { NO }_{x} \\
\text { Avg. }\end{array}$ & $\begin{array}{l}\text { Outlet } \\
\text { Peak } \\
\end{array}$ & $\begin{array}{l}\text { Opacity } \\
\text { Avg. } \\
\end{array}$ & $\begin{array}{l}\mathrm{CO}_{2} \\
\text { Avg. } \\
\end{array}$ & $\begin{array}{c}\text { Gross } \\
\text { Gerierations } \\
\text { KWH } \\
\end{array}$ & $\begin{array}{c}\text { Time } \\
\text { on } \\
\text { Line } \\
\text { Hr.-Min. }\end{array}$ \\
\hline & Date & & & & & \#I & MBtu & $\%$ & $\%$ & & \\
\hline & 1 & 505 & 565 & 0.50 & 0.60 & 0.40 & 0.46 & 10 & 10.7 & 250917 & 24 \\
\hline & 2 & 532 & 660 & 0.34 & 0.51 & 0.40 & 0.48 & 11 & 11.3 & 279542 & 24 \\
\hline & 3 & 495 & 560 & 0.28 & 0.37 & 0.48 & 0.57 & 14 & 11.2 & 291292 & 24 \\
\hline & 4 & 340 & 555 & 0.32 & 0.35 & 0.57 & 0.64 & 15 & 11.2 & 351458 & 24 \\
\hline & 5 & $-(a)$ & $-(a)$ & 0.33 & 0.37 & 0.66 & 0.72 & 16 & 11.4 & 352500 & 24 \\
\hline & 6 & $-(a)$ & $-(a)$ & 0.35 & 0.42 & 0.51 & 0.57 & 17 & 11.8 & 340250 & 24 \\
\hline & 7 & $-(a)$ & $-(a)$ & 0.17 & 0.31 & 0.48 & 0.60 & 15 & 10.3 & 214750 & 24 \\
\hline & 8 & $-(a)$ & $-(a)$ & 0.26 & 0.35 & 0.55 & 0.65 & 18 & 11.0 & 279000 & 24 \\
\hline & 9 & $-(a)$ & $-(a)$ & 0.06 & 0.06 & 0.24 & 0.40 & 13 & 4.8 & 80515 & $2-43$ \\
\hline & 10 & $45]$ & 585 & 0.37 & 0.41 & 0.37 & 0.41 & 17 & 11.7 & 302125 & 24 \\
\hline & 11 & 411 & 440 & 0.36 & 0.46 & 0.49 & 0.53 & 16 & 11.6 & 348042 & 24 \\
\hline & 12 & 362 & 420 & 0.27 & 0.35 & 0.45 & 0.51 & 15 & 11.0 & 277080 & $17-40$ \\
\hline$\Omega$ & 13 & 394 & 450 & 0.24 & 0.29 & 0.35 & 0.42 & 16 & 12.1 & 333250 & 24 \\
\hline - & 14 & 302 & 440 & 0.16 & 0.23 & 0.32 & 0.34 & 16 & 11.7 & 272083 & 24 \\
\hline - & 15 & 424 & 460 & 0.15 & 0.30 & 0.32 & 0.50 & 16 & 11.9 & 264917 & 24 \\
\hline & 16 & 416 & 460 & 0.14 & 0.18 & 0.32 & 0.34 & 16 & 12.8 & 337833 & 24 \\
\hline & 17 & 422 & 435 & 0.15 & 0.25 & 0.48 & 0.52 & 16 & 12.1 & 292083 & 24 \\
\hline & 18 & 300 & 410 & 0.14 & 0.23 & 0.44 & 0.59 & 18 & 10.5 & 258889 & $18-54$ \\
\hline & 19 & 242 & $2] 2$ & 0.19 & 0.25 & 0.51 & 0.67 & 17 & 10.7 & 225125 & 24 \\
\hline & 20 & 344 & 400 & 0.20 & 0.25 & 0.47 & 0.59 & 17 & 11.2 & 251333 & 24 \\
\hline & 21 & 330 & 380 & 0.12 & 0.22 & 0.45 & 0.59 & 15 & 10.6 & 203417 & 24 \\
\hline & 22 & 406 & 463 & 0.19 & 0.29 & 0.32 & 0.43 & 18 & 11.9 & 266611 & $21-50$ \\
\hline & 23 & 363 & 413 & 0.15 & 0.30 & 0.38 & 0.45 & 17 & 12.3 & 294208 & 24 \\
\hline & 24 & 401 & 457 & 0.26 & 0.34 & 0.33 & 0.37 & 17 & 12.5 & 322632 & $23-41$ \\
\hline & 25 & 0 & 0 & 0 & 0 & 0 & 0 & 0 & 0 & 0 & 0 \\
\hline & 26 & 261 & 380 & 0.16 & 0.23 & 0.42 & 0.55 & 16 & 11.3 & 245949 & $18-01$ \\
\hline & 27 & 233 & 420 & 0.14 & 0.23 & 0.42 & 0.45 & 15 & 11.2 & 207875 & 24 \\
\hline & 28 & 160 & 180 & 0.10 & 0.15 & 0.36 & 0.40 & 16 & 11.5 & 157402 & $22-38$ \\
\hline & 29 & 184 & 270 & 0.09 & 0.12 & 0.48 & 0.54 & 15 & 11.3 & 166208 & 24 \\
\hline & 30 & 476 & 591 & 0.30 & 0.45 & 0.38 & 0.54 & 15 & 13.5 & 278208 & 24 \\
\hline & 31 & 481 & 563 & 0.27 & 0.39 & 0.46 & 0.55 & 16 & 12.8 & 319958 & 24 \\
\hline
\end{tabular}

(a) No data due to water damage to inlet monitors.

Coal Consumption: 237,320 tons

Coal Analysis: $0.71 \%$ Sulfur

Scrubber Availability: $99.1 \%$

Total Time on Line: $677 \mathrm{hr} ., 27 \mathrm{~min}$. 
TABLE C.7.A Colstrip Unit \#1 Emission Data (June 1978)

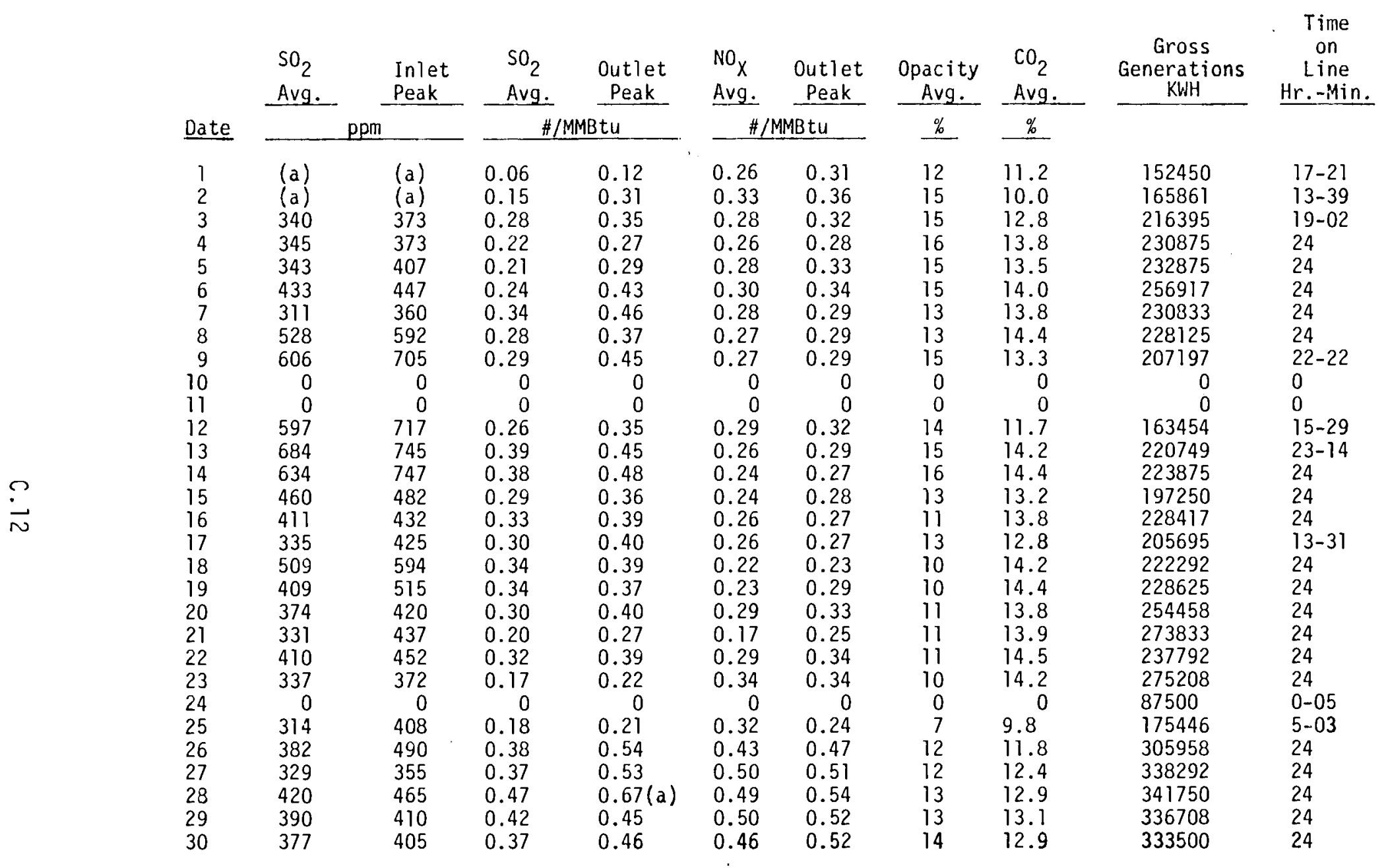

(a) No data due to recorder malfunctions.

Coal Consumption: 76,594.6 tons

Coal Analysis: $0.73 \%$ sulfur

Total Time on Line: $586 \mathrm{hr} ., 16 \mathrm{~min}$. 
TABLE C.7.B Colstrip Unit \#2 Emission Data (June 1978)

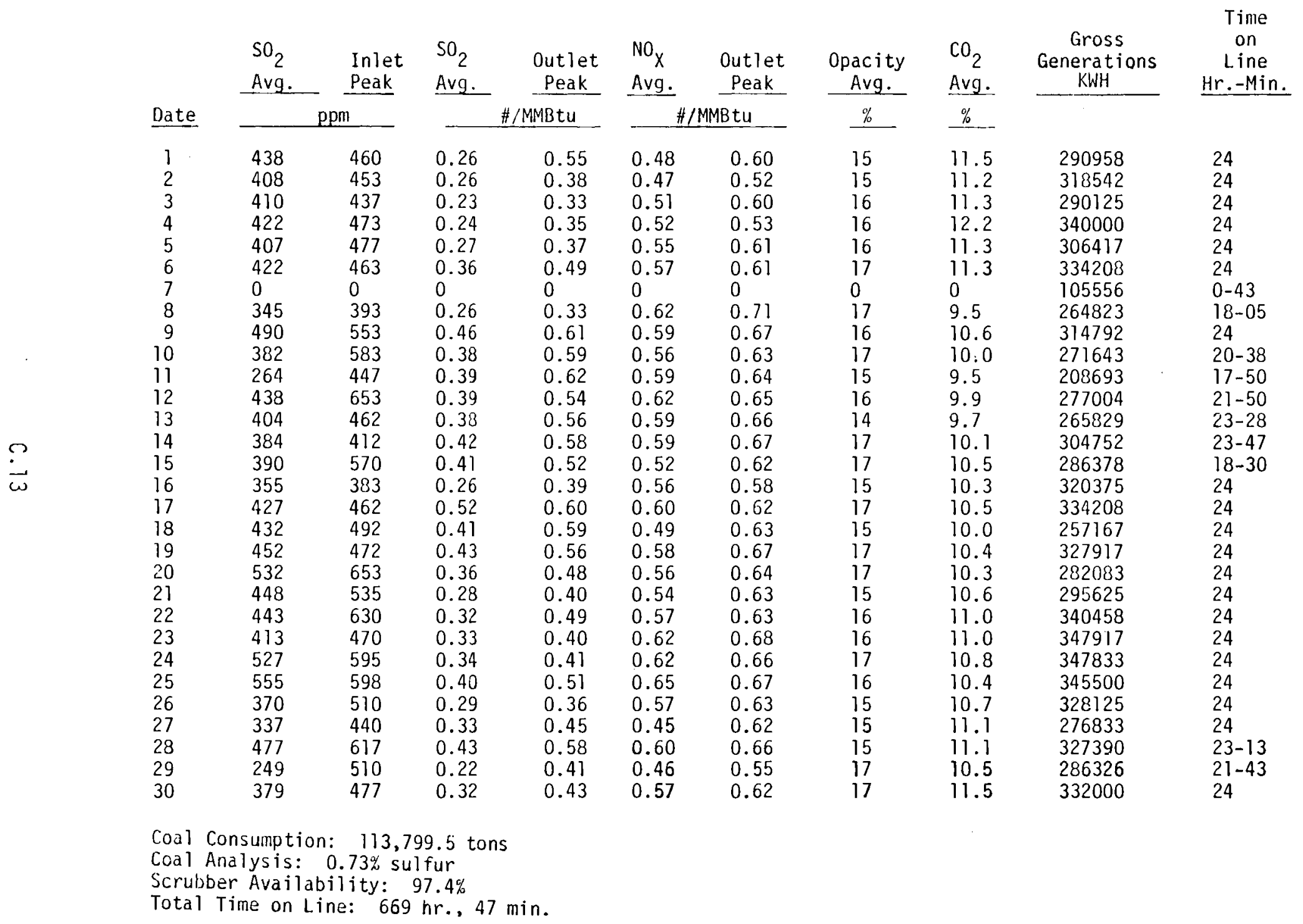


TABLE C.8.A Colstrip Unit \#1 Emission Data (JuTy 1978)

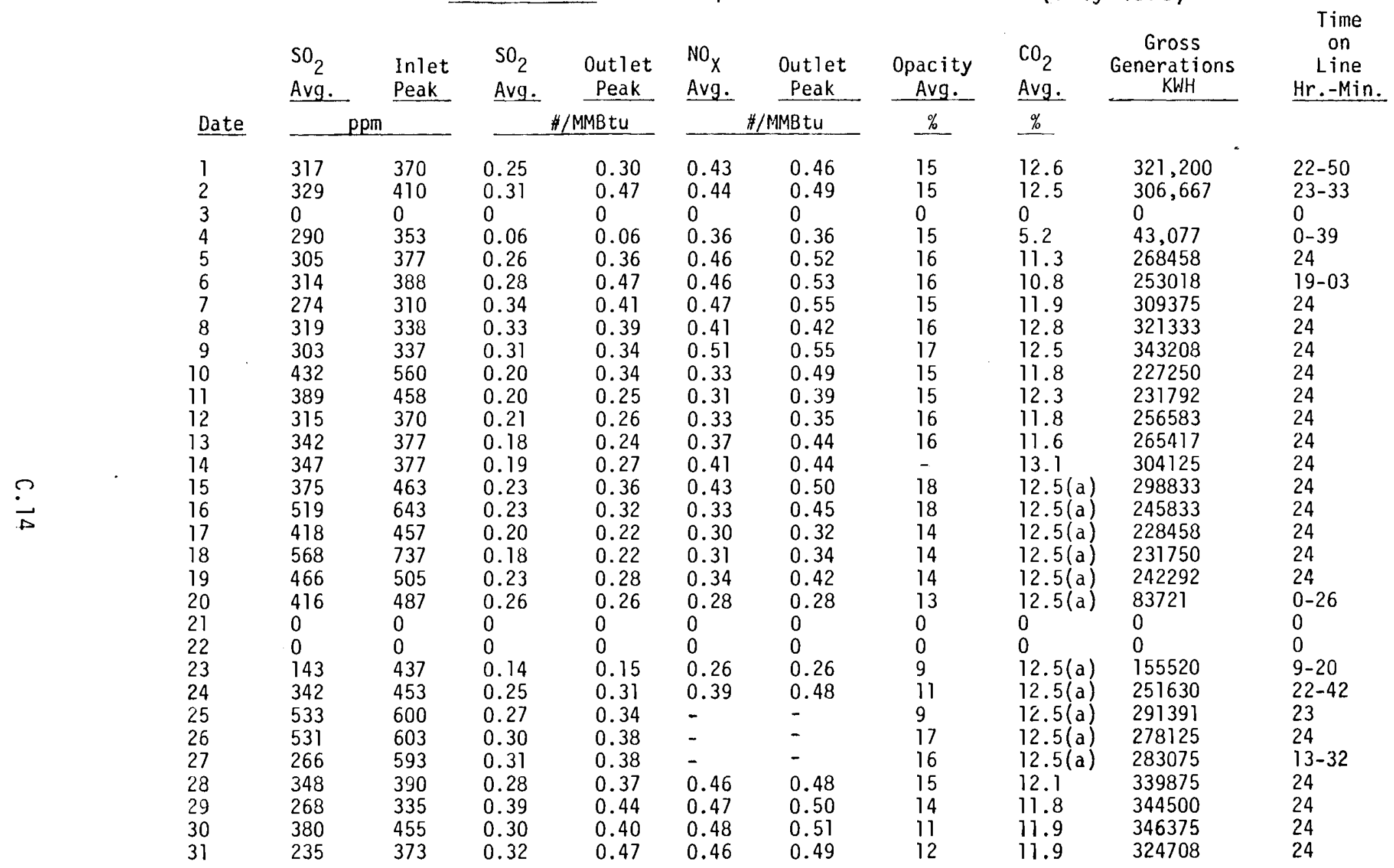

(a) "MMBtu values calculated using the design $\mathrm{CO}_{2}$ average of $12.5 \%$.

Coal Consumption: 100,294.4 tons

Coal Analysis: $0.60 \%$ sulfur

Scrubber Availability: $95.7 \%$

Total Time on Line: $591 \mathrm{hr} ., 05 \mathrm{~min}$. 
TABLE C.8.B Colstrip Unit \#2 Emission Data (July 1978)

\begin{tabular}{|c|c|c|c|c|c|c|c|c|c|c|}
\hline & $\begin{array}{l}\mathrm{SO}_{2} \\
\text { Avg. }\end{array}$ & $\begin{array}{l}\text { Inlet } \\
\text { Peak } \\
\end{array}$ & $\begin{array}{l}\mathrm{SO}_{2} \\
\text { Avg. }\end{array}$ & $\begin{array}{c}\text { Outlet } \\
\text { Peak } \\
\end{array}$ & $\begin{array}{l}\mathrm{NO}_{X} \\
\text { Avg. }\end{array}$ & $\begin{array}{c}\text { Outlet } \\
\text { Peak } \\
\end{array}$ & $\begin{array}{c}\text { Opacity } \\
\text { Avg. } \\
\end{array}$ & $\begin{array}{l}\mathrm{CO}_{2} \\
\text { Avg. }\end{array}$ & $\begin{array}{c}\text { Gross } \\
\text { Generations } \\
\text { KWH } \\
\end{array}$ & $\begin{array}{c}\text { Time } \\
\text { on } \\
\text { Line } \\
\mathrm{Hr} \text {.-Min. } \\
\end{array}$ \\
\hline Date & & & & MBtu & & Btu & $\%$ & $\%$ & & \\
\hline $\begin{array}{l}1 \\
2 \\
3 \\
4 \\
5 \\
6 \\
7 \\
8 \\
9 \\
10 \\
11 \\
12 \\
13 \\
14 \\
15 \\
16 \\
17 \\
18 \\
19 \\
20 \\
21 \\
22 \\
23 \\
24 \\
25 \\
26 \\
27 \\
23 \\
29 \\
30 \\
31\end{array}$ & $\begin{array}{l}0(a) \\
350 \\
114 \\
470 \\
515 \\
308 \\
-(a) \\
- \\
- \\
- \\
- \\
- \\
- \\
- \\
- \\
- \\
- \\
- \\
- \\
- \\
- \\
- \\
- \\
- \\
- \\
- \\
- \\
- \\
- \\
- \\
-\end{array}$ & $\begin{array}{l}0(a) \\
550 \\
273 \\
517 \\
620 \\
447 \\
-(a) \\
- \\
- \\
- \\
- \\
- \\
- \\
- \\
- \\
- \\
- \\
- \\
- \\
- \\
- \\
- \\
- \\
- \\
- \\
- \\
- \\
- \\
- \\
- \\
-\end{array}$ & $\begin{array}{l}0.15 \\
0.21 \\
0.31 \\
0.32 \\
0.32 \\
0.26 \\
0 \\
0 \\
0 \\
0.17 \\
0.18 \\
0.17 \\
0.12 \\
0.10 \\
0.06 \\
0.09 \\
0.14 \\
0.20 \\
0.16 \\
0.32 \\
0.20 \\
0.24 \\
0.23 \\
0.25 \\
0.23 \\
0.23 \\
0.34 \\
0.24 \\
0.53 \\
0.41 \\
0.28\end{array}$ & $\begin{array}{l}0.21 \\
0.32 \\
0.45 \\
0.39 \\
0.52 \\
0.44 \\
0 \\
0 \\
0 \\
0.24 \\
0.20 \\
0.31 \\
0.21 \\
0.21 \\
0.09 \\
0.13 \\
0.24 \\
0.29 \\
0.19 \\
0.52 \\
0.30 \\
0.28 \\
0.27 \\
0.29 \\
0.27 \\
0.35 \\
0.47 \\
0.36 \\
0.57 \\
0.53 \\
0.45\end{array}$ & $\begin{array}{l}0.43 \\
0.51 \\
0.34 \\
0.59 \\
0.60 \\
0.45 \\
0 \\
0 \\
0 \\
0.37 \\
0.42 \\
0.47 \\
0.47 \\
0.52 \\
0.53 \\
0.57 \\
0.56 \\
0.63 \\
0.55 \\
0.58 \\
0.52 \\
0.54 \\
0.51 \\
0.51 \\
0.55 \\
0.57 \\
0.63 \\
0.61 \\
0.61 \\
0.61 \\
0.61\end{array}$ & $\begin{array}{l}0.55 \\
0.70 \\
0.37 \\
0.66 \\
0.67 \\
0.58 \\
0 \\
0 \\
0 \\
0.42 \\
0.52 \\
0.58 \\
0.54 \\
0.57 \\
0.57 \\
0.64 \\
0.63 \\
0.66 \\
0.65 \\
0.71 \\
0.61 \\
0.56 \\
0.53 \\
0.59 \\
0.59 \\
0.63 \\
0.67 \\
0.64 \\
0.65 \\
0.67 \\
0.70\end{array}$ & $\begin{array}{l}17 \\
17 \\
12 \\
14 \\
15 \\
15 \\
0 \\
0 \\
0 \\
15 \\
14 \\
15 \\
15 \\
17 \\
16 \\
15 \\
15 \\
14 \\
15 \\
16 \\
15 \\
15 \\
15 \\
16 \\
16 \\
16 \\
17 \\
17 \\
16 \\
15 \\
14\end{array}$ & $\begin{array}{l}11.5 \\
10.3 \\
10.5 \\
10.8 \\
10.7 \\
10.2 \\
0 \\
0 \\
0 \\
10.7 \\
10.6 \\
10.4 \\
11.0 \\
10.8 \\
10.9 \\
10.8 \\
10.4 \\
10.6 \\
10.4 \\
10.7 \\
10.7 \\
10.6 \\
10.7 \\
10.9 \\
10.7 \\
10.8 \\
10.9 \\
10.9 \\
10.8 \\
10.6 \\
9.7\end{array}$ & $\begin{array}{l}252625^{-} \\
296465 \\
214439 \\
325625 \\
318167 \\
235711 \\
0 \\
0 \\
22388 \\
184833 \\
222708 \\
209375 \\
197875 \\
237750 \\
252667 \\
277667 \\
287212 \\
323917 \\
296083 \\
336417 \\
290708 \\
331958 \\
331583 \\
321292 \\
309000 \\
289542 \\
333583 \\
321833 \\
330333 \\
327833 \\
280942\end{array}$ & $\begin{array}{l}24 \\
22-38 \\
16-50 \\
24-00 \\
24-00 \\
23-08 \\
0 \\
0 \\
00-40 \\
24 \\
24 \\
24 \\
24 \\
24 \\
24 \\
24 \\
22-08 \\
24 \\
24 \\
24 \\
24 \\
24 \\
24 \\
24 \\
24 \\
24 \\
24 \\
24 \\
24 \\
24 \\
22-18\end{array}$ \\
\hline
\end{tabular}

(a) No data due to monitor equipment malfunction.

Coal Consumption: $111,395.7$ tons

Coal Analysis: $0.60 \%$ sulfur

Scrubber Availability: $96.4 \%$

Total Time on Line: $659 \mathrm{hr} ., 42 \mathrm{~min}$. 
TABLE C.9.A Colstrip Unit \#1 Emission Data (August 1978)

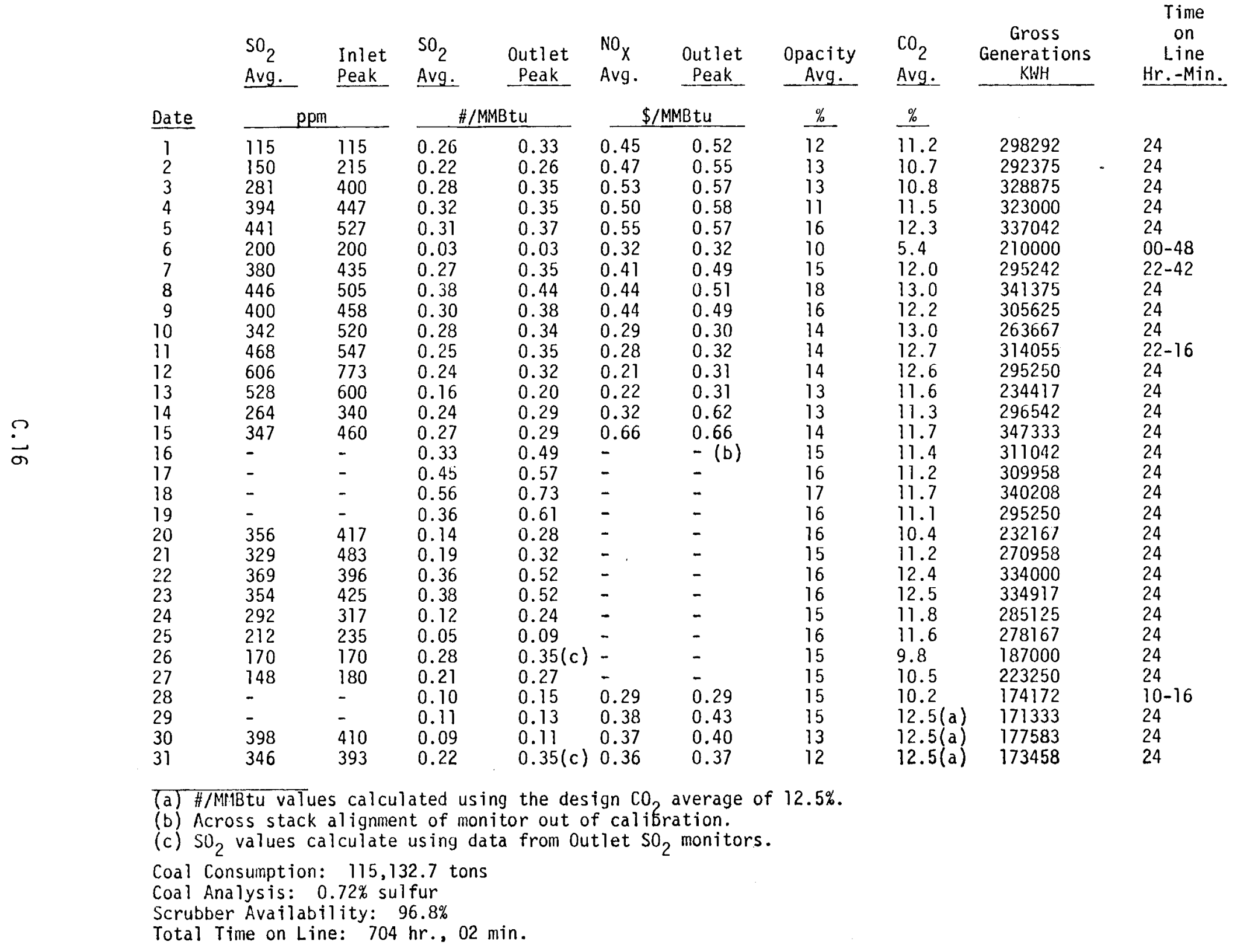


TABLE C.9.B Colstrip Unit \#2 Emission Data (August 1978)

\begin{tabular}{|c|c|c|c|c|c|c|c|c|c|c|}
\hline & $\begin{array}{l}\mathrm{SO}_{2} \\
\text { Avg. } \\
\end{array}$ & $\begin{array}{l}\text { Inlet } \\
\text { Peak } \\
\end{array}$ & $\begin{array}{l}\mathrm{SO}_{2} \\
\mathrm{Avg} . \\
\end{array}$ & $\begin{array}{c}\text { Outlet } \\
\text { Peak }\end{array}$ & $\begin{array}{l}\text { NO } \\
\text { Avg. }\end{array}$ & $\begin{array}{l}\text { Outlet } \\
\text { Peak }\end{array}$ & $\begin{array}{c}\text { Opacity } \\
\text { Avg. }\end{array}$ & $\begin{array}{l}\mathrm{CO}_{2} \\
\mathrm{Avg} .\end{array}$ & $\begin{array}{c}\text { Gross } \\
\text { Generations } \\
\text { KWH }\end{array}$ & $\begin{array}{c}\text { Time } \\
\text { on } \\
\text { Line } \\
\text { Hr.-Min. }\end{array}$ \\
\hline Date & & & & Btu & & & $\%$ & $\%$ & & \\
\hline $\begin{array}{l}1 \\
2 \\
3 \\
4 \\
5 \\
6 \\
7 \\
8 \\
9 \\
10 \\
11 \\
12 \\
13 \\
14 \\
15 \\
16 \\
17 \\
18 \\
19 \\
20 \\
21 \\
22 \\
23 \\
24 \\
25 \\
26 \\
27 \\
28 \\
29 \\
30 \\
31\end{array}$ & $\begin{array}{l}- \\
503 \\
465 \\
422 \\
383 \\
332 \\
415 \\
367 \\
450 \\
512 \\
- \\
- \\
- \\
- \\
459 \\
468 \\
- \\
- \\
- \\
513 \\
- \\
- \\
- \\
- \\
- \\
434 \\
467 \\
430 \\
446 \\
402 \\
510\end{array}$ & $\begin{array}{l}-(b) \\
527 \\
520 \\
490 \\
417 \\
355 \\
580 \\
428 \\
533 \\
520 \\
-(b) \\
- \\
- \\
- \\
470 \\
483 \\
- \\
- \\
-(b) \\
527 \\
-(b) \\
- \\
-(b) \\
- \\
- \\
443 \\
517 \\
447 \\
463 \\
410 \\
553\end{array}$ & $\begin{array}{l}0.31 \\
0.33 \\
0.35 \\
0.34 \\
0.37 \\
0.31 \\
0.27 \\
0.30 \\
0.43 \\
0.43 \\
0.29 \\
0.38 \\
0.34 \\
0.28 \\
0.29 \\
0.37 \\
0.19 \\
0 \\
0.29 \\
0.43 \\
0.39 \\
0 \\
0.31 \\
0.29 \\
0.21 \\
0.40 \\
0.33 \\
0.41 \\
0.30 \\
0.28 \\
0.27\end{array}$ & $\begin{array}{l}0.36 \\
0.41 \\
0.49 \\
0.38 \\
0.46 \\
0.37 \\
0.40 \\
0.38 \\
0.48 \\
0.49 \\
0.35 \\
0.33 \\
0.38 \\
0.36 \\
0.36 \\
0.42 \\
0.25 \\
0 \\
0.35(c) \\
0.60 \\
0.47 \\
0 \\
0.39(c) \\
0.37(c) \\
0.30(c) \\
0.46(c) \\
0.41(c) \\
0.49(c) \\
0.39(c) \\
0.35(c) \\
0.33(c)\end{array}$ & $\begin{array}{l}0.62 \\
0.56 \\
0.55 \\
0.61 \\
0.61 \\
0.58 \\
0.51 \\
0.58 \\
0.54 \\
0.54 \\
0.51 \\
0.62 \\
0.61 \\
0.60 \\
0.63 \\
0.64 \\
0.50 \\
0 \\
0.48 \\
0.59 \\
0.50 \\
0 \\
- \\
- \\
0.58 \\
0.54 \\
0.56 \\
0.59 \\
0.45 \\
0 \\
0.47\end{array}$ & $\begin{array}{l}0.70 \\
0.61 \\
0.67 \\
0.62 \\
0.65 \\
0.61 \\
0.62 \\
0.67 \\
0.56 \\
0.63 \\
0.59 \\
0.63 \\
0.66 \\
0.65 \\
0.68 \\
0.67 \\
0.56 \\
0 \\
0.51 \\
0.63 \\
0.61 \\
0 \\
-(d) \\
-(d) \\
0.62 \\
0.59 \\
0.60 \\
0.63 \\
0.50 \\
0 \\
0.52\end{array}$ & $\begin{array}{l}14 \\
15 \\
14 \\
15 \\
16 \\
17 \\
17 \\
14 \\
15 \\
15 \\
15 \\
15 \\
17 \\
15 \\
15 \\
15 \\
10 \\
0 \\
9 \\
12 \\
14 \\
0 \\
-(d) \\
-(d) \\
12 \\
14 \\
12 \\
12 \\
8 \\
0 \\
12\end{array}$ & $\begin{array}{l}9.9 \\
10.6 \\
10.5 \\
10.3 \\
10.8 \\
10.8 \\
10.6 \\
10.1 \\
10.8 \\
11.1 \\
10.5 \\
11.0 \\
10.8 \\
10.2 \\
10.9 \\
10.7 \\
8.3 \\
0 \\
12.5(\mathrm{a}) \\
10.9 \\
11.0 \\
0 \\
12.5(\mathrm{a}) \\
12.5 \\
12.5 \\
12.5 \\
12.5 \\
12.5 \\
12.5 \\
12.5 \\
12.5\end{array}$ & $\begin{array}{l}301833 \\
297458 \\
292625 \\
297542 \\
325417 \\
324667 \\
285583 \\
302708 \\
328250 \\
321667 \\
277708 \\
324458 \\
321708 \\
269167 \\
323625 \\
325259 \\
198422 \\
0 \\
184957 \\
289507 \\
289549 \\
0 \\
189829 \\
286268 \\
316583 \\
319542 \\
281667 \\
329333 \\
284333 \\
301625 \\
264167\end{array}$ & $\begin{array}{l}24 \\
24 \\
24 \\
24 \\
24 \\
24 \\
24 \\
24 \\
24 \\
24 \\
24 \\
24 \\
24 \\
24 \\
24 \\
22-10 \\
06-58 \\
0 \\
10-34 \\
22-18 \\
23-44 \\
0 \\
14-39 \\
17-33 \\
24 \\
24 \\
24 \\
24 \\
24 \\
24 \\
24\end{array}$ \\
\hline
\end{tabular}

(a) \#/MMBtu values calculated using the design $\mathrm{CO}_{2}$ average of $12.5 \%$.

(b) No data due to monitor equipinent malfunction.

(c) $\mathrm{SO}_{2}$ values calculated using data from Outlet $\mathrm{SO}_{2}$ monitors.

(d) Rewiring of monitors.

Coal Consumption: $110,542.6$ tons

Coal Analysis: $0.72 \%$ sulfur

Scrubber Availability: $99.2 \%$

Total Time on Line: $645 \mathrm{hr} ., 56 \mathrm{~min}$. 
TABLE C. 10.A Colstrip Unit \#1 Emission Data (September 1978)

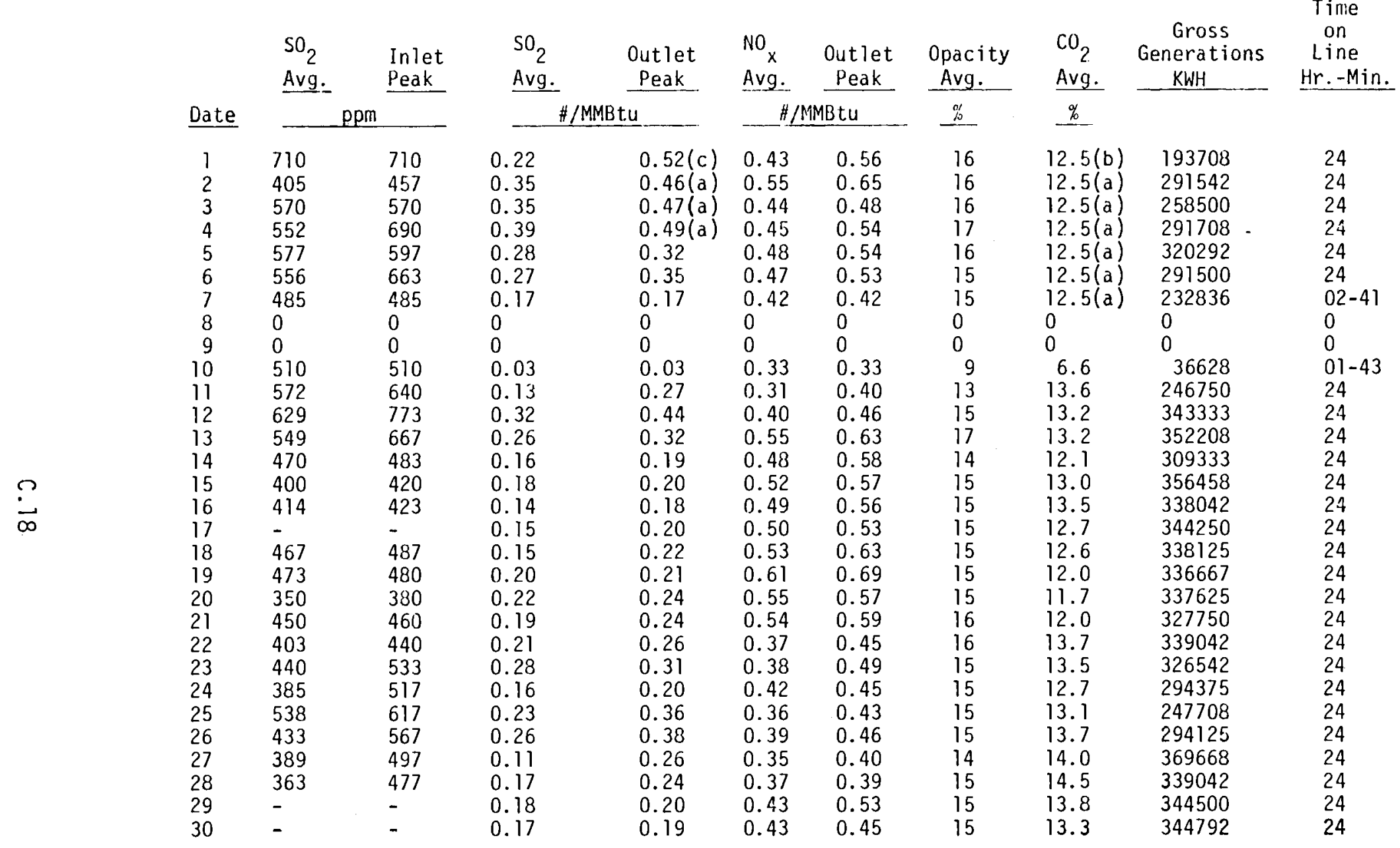

(a) Data from one inlet monitor only.

(b) \#/MMBtu values calculated using the design $\mathrm{CO}_{2}$ average of $12.5 \%$.

(c) $\mathrm{SO}_{2}$ values calculated using data from outlet $\mathrm{SO}_{2}$ monitors.

Coal Consumption: $111,349.1$ tons

Coal Analysis: $0.65 \%$ Sulfur

Scrubber Availability: $96.3 \%$

Total Time on Line: $628 \mathrm{hrs} .24 \mathrm{~min}$. 
TABLE C.10.B Colstrip Unit \#2 Emission Data (September 1978)

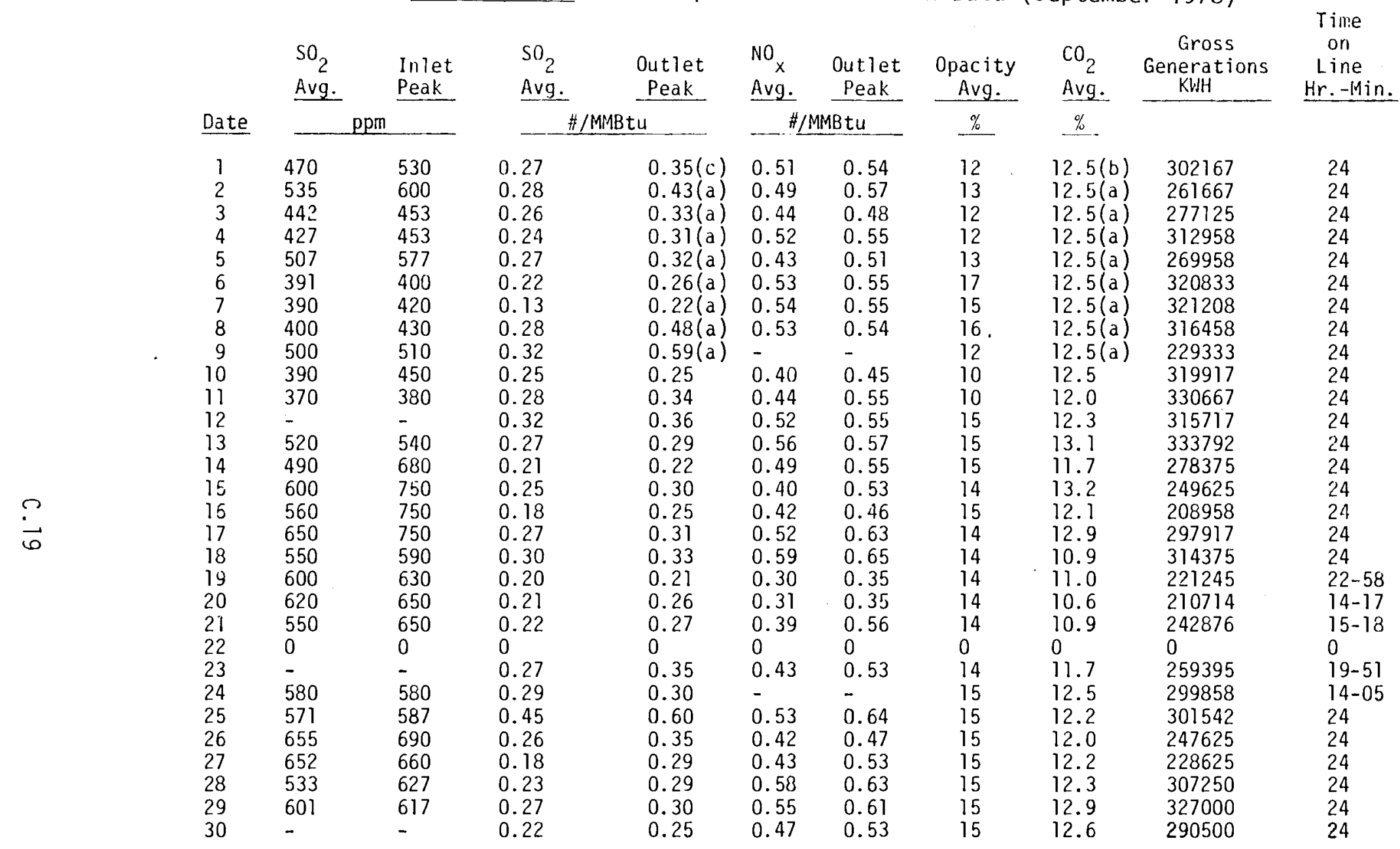

(a) Data from one inlet monitor only.

(b) $f$ MMBtu values calculated using the design $\mathrm{CO}_{2}$ average of $12.5 \%$

(c) $\mathrm{SO}_{2}$ values calculated using data from Outlet $\mathrm{SO}_{2}$ monitors.

Coal Consumption: $104,778.7$ tons

Coal Analysis: $0.65 \%$ Sulfur

Scrubber Availability: $94.4 \%$

Total Time on Line: 662 hrs. $29 \mathrm{~min}$. 
TABLE C.11.A Colstrip Unit \#1 Emission Data (0ctober 1978)

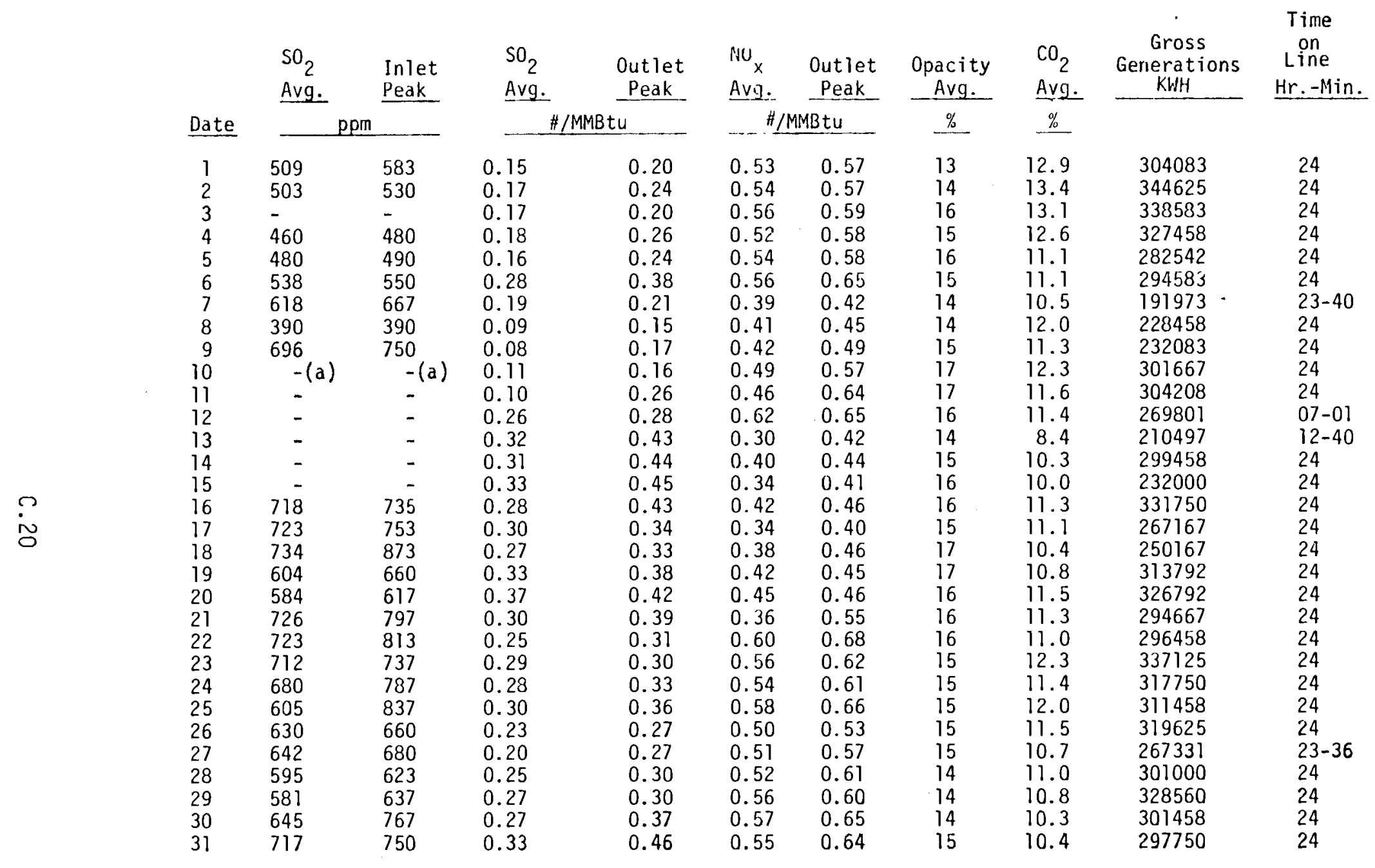

(a) Monitor equipment failure

Coal Consumption: 119,643.3 tons

Coal Analysis: $0.69 \%$ Sulfur

Scrubber Availability: $94.5 \%$

Total Time on Line: 714 hrs., $57 \mathrm{~min}$. 
IABLE C.11.B Colstrip Unit \#2 Emission Data (October 1978)

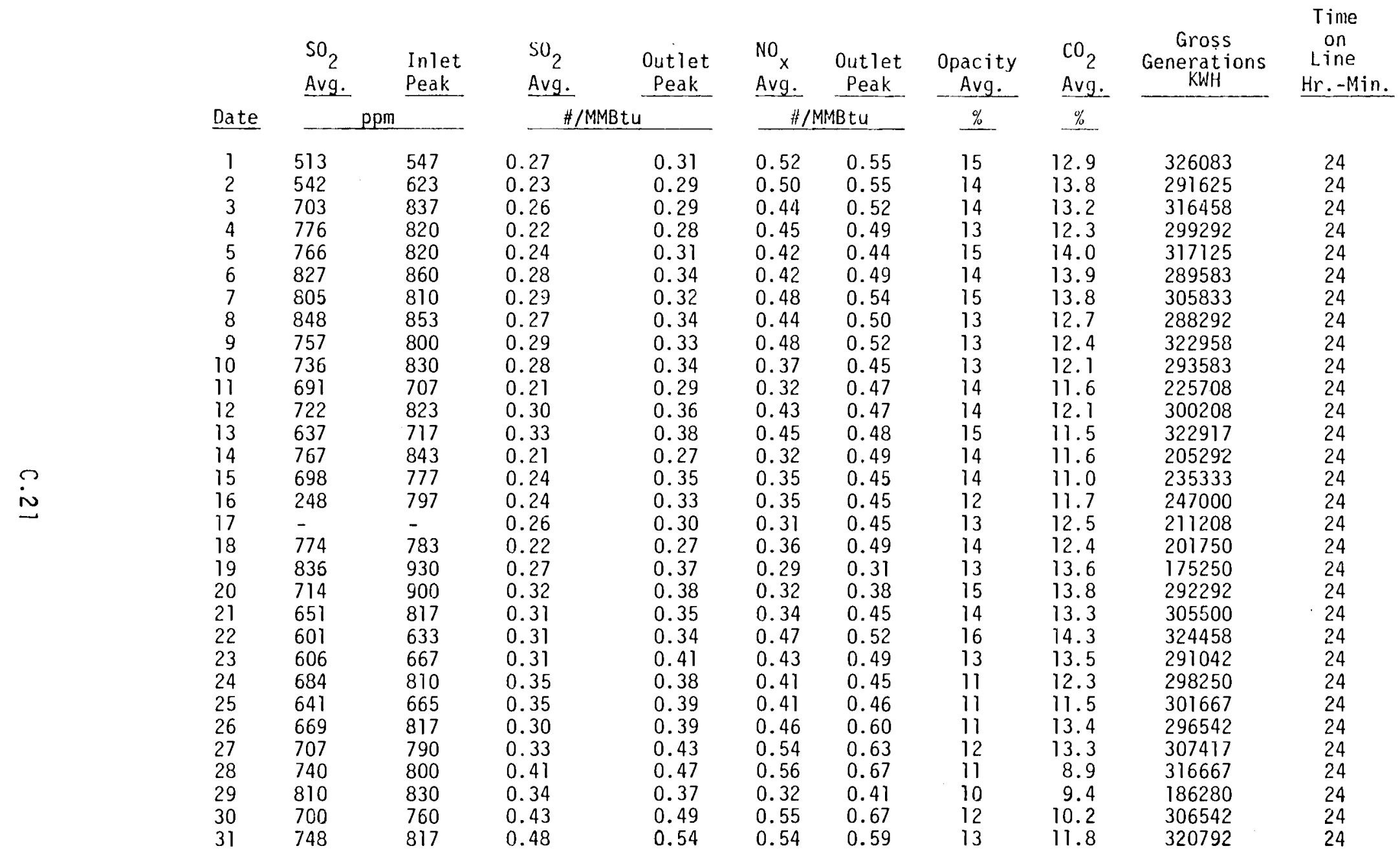

Coal Consumption: $118,465.6$ tons

Coal Analysis: $0.69 \%$ Sulfur

Scrubber Availability: $99.6 \%$

Total Time on Line: 744 hrs. 
TABLE C.12.A Colstrip Unit \#1 Emission Data (November 1978)

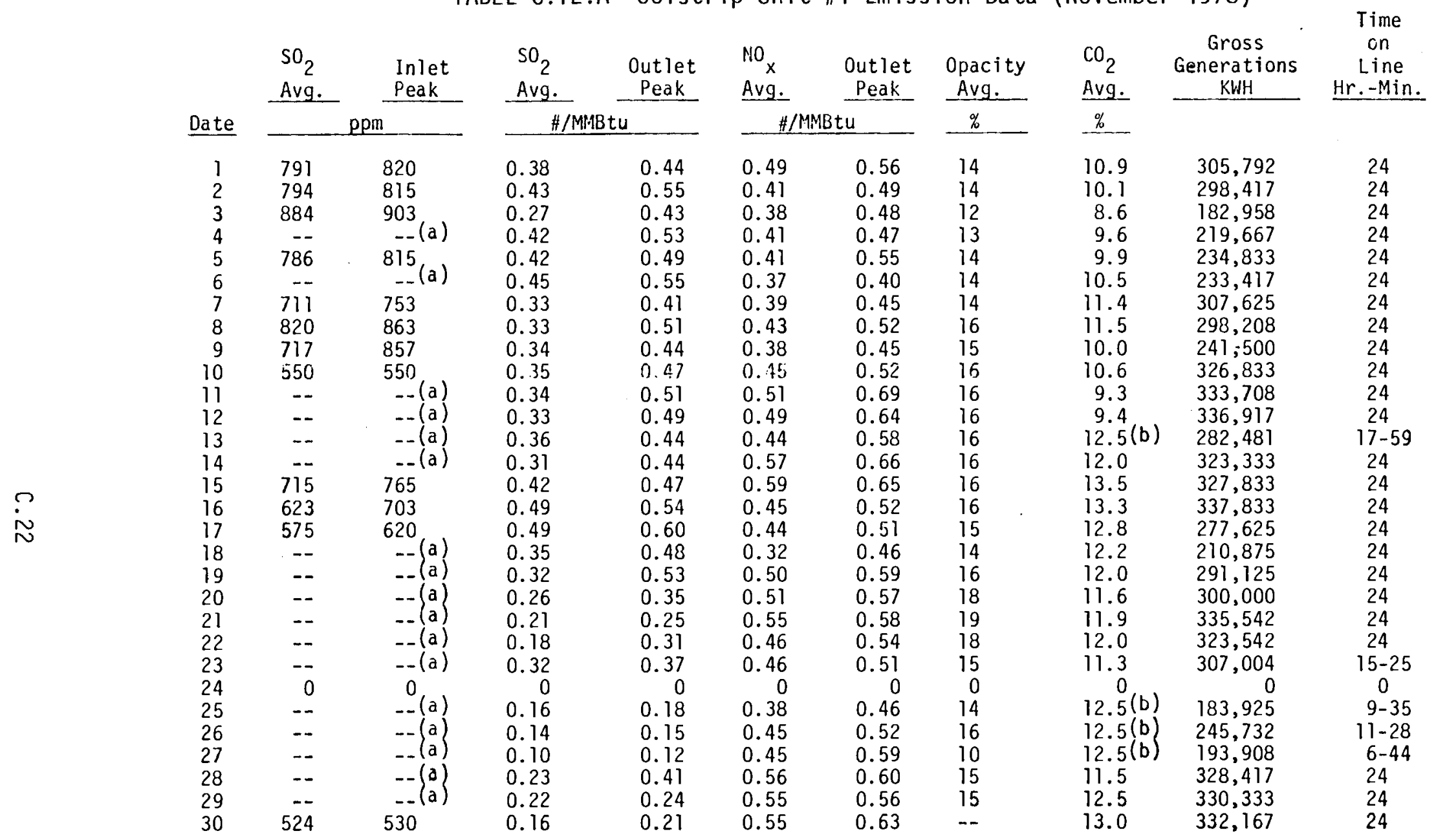

(a) Monitoring Equipment Malfunction.

(b) $\frac{H}{\pi}$ MMBTU values calculated using the design $\mathrm{CO}_{2}$ average of $12,5 \%$.

Coal Consumption: 106,234.1 tons

Coal Analysis: $0.74 \%$ Sulfur

Scrubber Availability: $91.1 \%$

Total Time on Line: $637 \mathrm{hrs} ., 11$ minutes 
TABLE C.12.B Colstrip Unit \#2 Emission Data (November 1978)

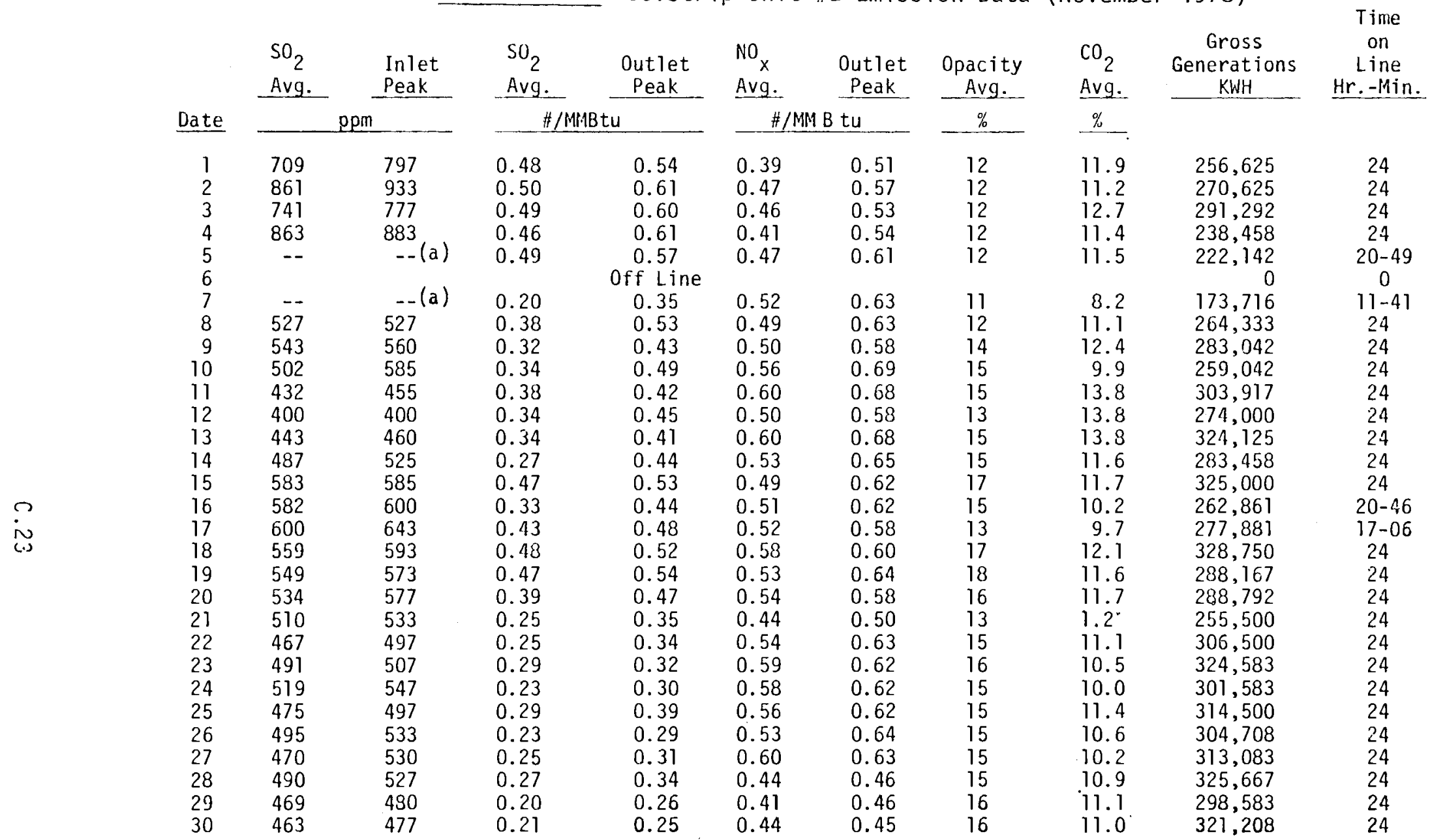

(a) Monitoring Equipment Malfunction

Coal Consumption: $116,195.2$ tons

Coal Analysis: $0.74 \%$ Sulfur

Scrubber Availability: $99.5 \%$

Total Time on Line: $668 \mathrm{hrs} ., 22$ mins. 
IABLE C.13.A Colstrip Unit \#1 Emission Data (December 1978)

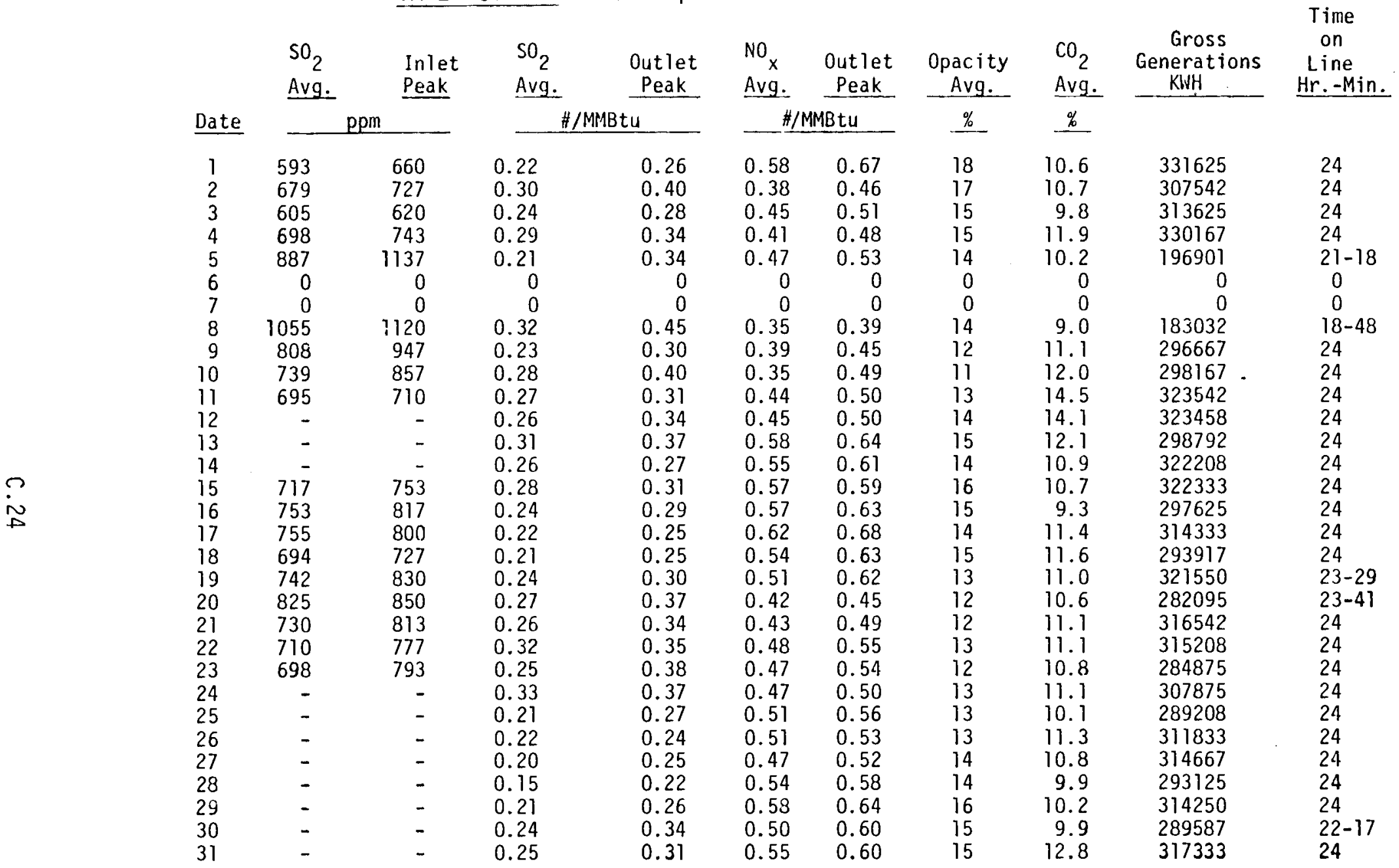

Note: November 30 opacity average for unit 1 equals $16 \%$.

Coal Consumption: 121,574.6 tons

Scrubber Availability: $96.7 \%$

Total Time on Line: 685 hrs., $33 \mathrm{~min}$. 
TABLE C.13.B Colstrip Unit \#2 Emission Data (December 1978)

\begin{tabular}{|c|c|c|c|c|c|c|c|c|c|c|}
\hline \multirow[b]{2}{*}{ Date } & $\begin{array}{l}\mathrm{SO}_{2} \\
2 \\
\text { Avg. }\end{array}$ & $\begin{array}{l}\text { Inlet } \\
\text { Peak }\end{array}$ & $\begin{array}{l}\mathrm{SO}_{2} \\
\text { Avg. }\end{array}$ & $\begin{array}{c}\text { Outlet } \\
\text { Peak }\end{array}$ & $\begin{array}{l}\text { NO } x \\
\text { Avg. }\end{array}$ & $\begin{array}{c}\text { Outlet } \\
\text { Peak }\end{array}$ & \multirow{2}{*}{$\begin{array}{c}\text { Opacity } \\
\text { Avg. } \\
\frac{\%}{4}\end{array}$} & \multirow{2}{*}{$\begin{array}{l}\mathrm{CO}_{2} \\
\text { Avg. } \\
\end{array}$} & $\begin{array}{c}\text { Gross } \\
\text { Generations } \\
\text { KLH } \\
\end{array}$ & $\begin{array}{c}\text { Time } \\
\text { on } \\
\text { Line } \\
\text { Hr. -Min. }\end{array}$ \\
\hline & \multicolumn{2}{|c|}{$\mathrm{ppm}$} & \multicolumn{2}{|c|}{$\# /$ MMBtu } & \multicolumn{2}{|c|}{ \#/MMB tu } & & & & \\
\hline 1 & 473 & 503 & 0.22 & 0.28 & 0.48 & 0.53 & 16 & 11.8 & 289375 & 24 \\
\hline 2 & 524 & 603 & 0.29 & 0.34 & 0.52 & 0.60 & 14 & 10.4 & 309000 & 24 \\
\hline 3 & 529 & 563 & 0.23 & 0.31 & 0.51 & 0.63 & 14 & 11.4 & $296208^{\circ}$ & 24 \\
\hline 4 & 547 & 593 & $0.3]$ & 0.39 & 0.50 & 0.55 & 17 & 11.8 & 319917 & 24 \\
\hline 5 & 570 & 607 & 0.37 & 0.47 & 0.41 & 0.49 & 17 & 11.2 & 295708 & 24 \\
\hline 6 & 529 & 500 & 0.36 & 0.42 & 0.48 & 0.53 & 18 & 10.9 & 321875 & 24 \\
\hline 7 & 598 & 693 & 0.26 & 0.35 & 0.14 & 0.47 & 15 & 9.7 & 294125 & 24 \\
\hline 8 & 628 & 640 & 0.35 & 0.43 & 0.48 & 0.55 & 16 & 10.0 & 313667 & 24 \\
\hline 9 & 612 & 643 & 0.24 & 0.39 & 0.32 & 0.37 & 16 & 10.6 & 254708 & 24 \\
\hline 10 & 568 & 587 & 0.28 & 0.31 & 0.38 & 0.41 & 17 & 11.1 & 318417 & 24 \\
\hline 11 & 588 & 687 & 0.24 & 0.29 & 0.43 & 0.45 & 14 & 10.2 & 318042 & 24 \\
\hline 12 & 832 & 877 & 0.34 & 0.44 & 0.35 & 0.39 & 14 & 10.4 & 235583 & 24 \\
\hline 13 & - & - & 0.36 & 0.52 & 0.36 & 0.40 & 15 & 10.6 & 206000 & 24 \\
\hline 14 & - & - & 0.23 & 0.30 & 0.33 & 0.42 & 12 & 10.9 & 243375 & 24 \\
\hline 15 & 728 & 769 & 0.21 & 0.26 & 0.23 & 0.25 & 13 & 11.5 & 224166 & 24 \\
\hline 16 & 749 & 817 & 0.25 & 0.42 & 0.26 & 0.28 & 14 & 11.8 & 234250 & 24 \\
\hline 17 & 657 & 680 & 0.18 & 0.25 & 0.30 & 0.34 & 16 & 11.6 & 284167 & 24 \\
\hline 18 & - & - & 0.21 & 0.34 & 0.33 & 0.35 & 18 & 11.6 & 313000 & 24 \\
\hline 19 & 628 & 713 & 0.19 & 0.27 & 0.25 & 0.38 & 17 & 11.7 & 265583 & 24 \\
\hline 20 & - & - & 0.37 & 0.49 & 0.46 & 0.47 & 15 & 12.7 & 233917 & 24 \\
\hline 21 & - & - & 0.21 & 0.32 & 0.40 & 0.48 & 14 & 11.2 & 224583 & 24 \\
\hline 22 & 597 & 617 & 0.27 & 0.37 & 0.51 & 0.61 & 15 & 11.4 & 276917 & 24 \\
\hline 23 & 563 & 620 & 0.38 & 0.38 & 0.58 & 0.63 & 16 & 11.6 & 321458 & 24 \\
\hline 24 & 708 & 890 & 0.30 & 0.36 & 0.44 & 0.50 & 13 & 11.4 & 283750 & 24 \\
\hline 25 & 600 & 630 & 0.29 & 0.32 & 0.52 & 0.54 & 16 & 11.8 & 320167 & 24 \\
\hline 26 & 583 & 613 & 0.26 & 0.28 & 0.55 & 0.58 & 16 & 11.6 & 320500 & 24 \\
\hline 27 & 579 & 739 & 0.20 & 0.27 & 0.50 & 0.56 & 16 & 11.1 & 280292 & 24 \\
\hline 28 & 470 & 503 & 0.19 & 0.21 & 0.53 & 0.57 & 15 & 11.4 & 308042 & 24 \\
\hline 29 & - & - & 0.21 & 0.27 & 0.48 & 0.62 & 17 & 11.4 & 319542 & 24 \\
\hline 30 & - & - & 0.29 & 0.40 & 0.61 & 0.63 & 17 & 11.4 & 313625 & 24 \\
\hline 31 & - & - & 0.22 & 0.38 & 0.51 & 0.56 & 17 & 11.0 & 265792 & 24 \\
\hline
\end{tabular}

Coal Consumption: $134,834.4$ tons

Scrubber Availability: $91.2 \%$

Total TIme on Line: 774 hrs., 00 mins. 

APPENDIX D

EXCESSES OF CLASS 1 AIR QUALITY STANDARD REGARDLESS OF STATION LOCATION DURING 1978 


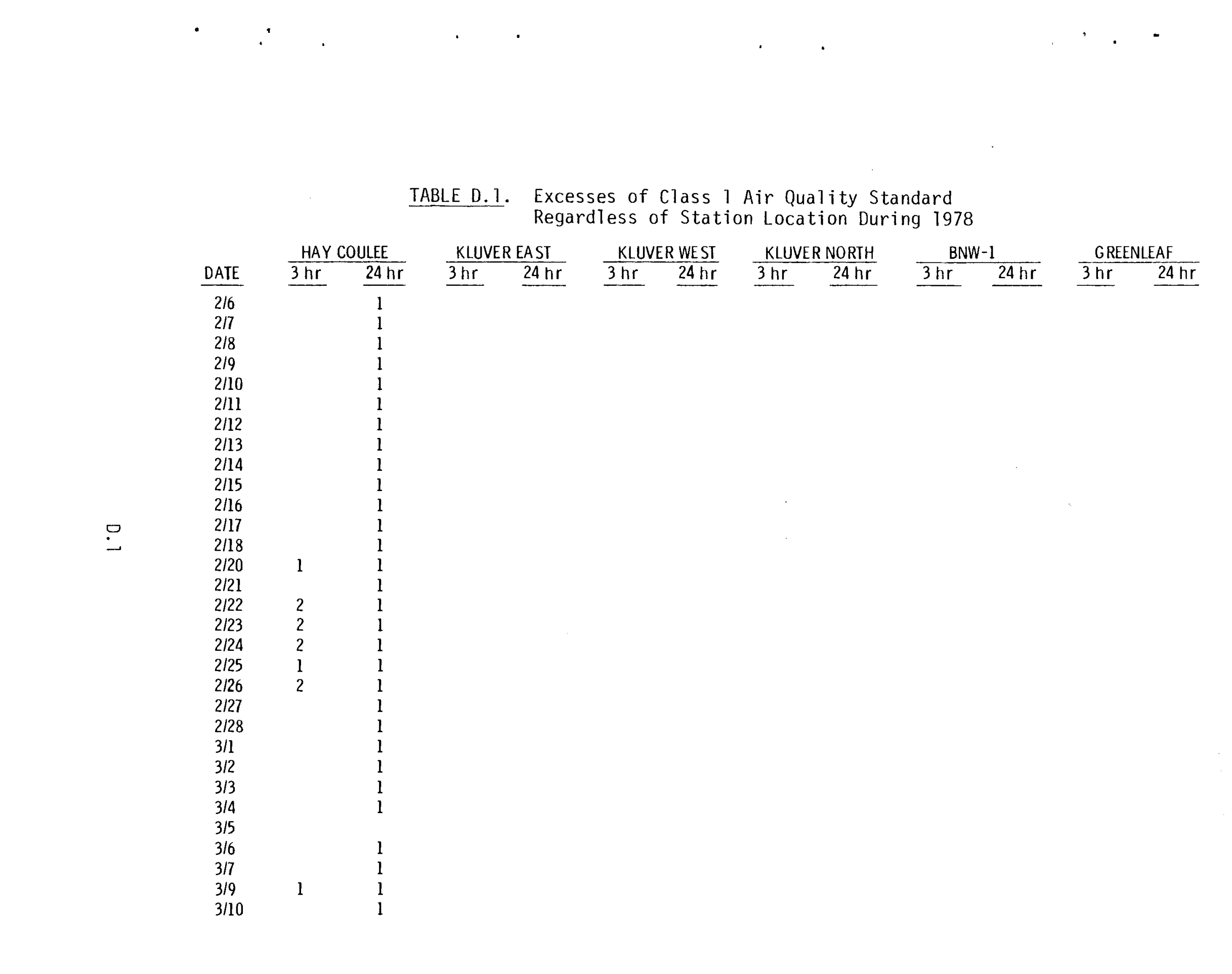


TABLE D.1. (continued)

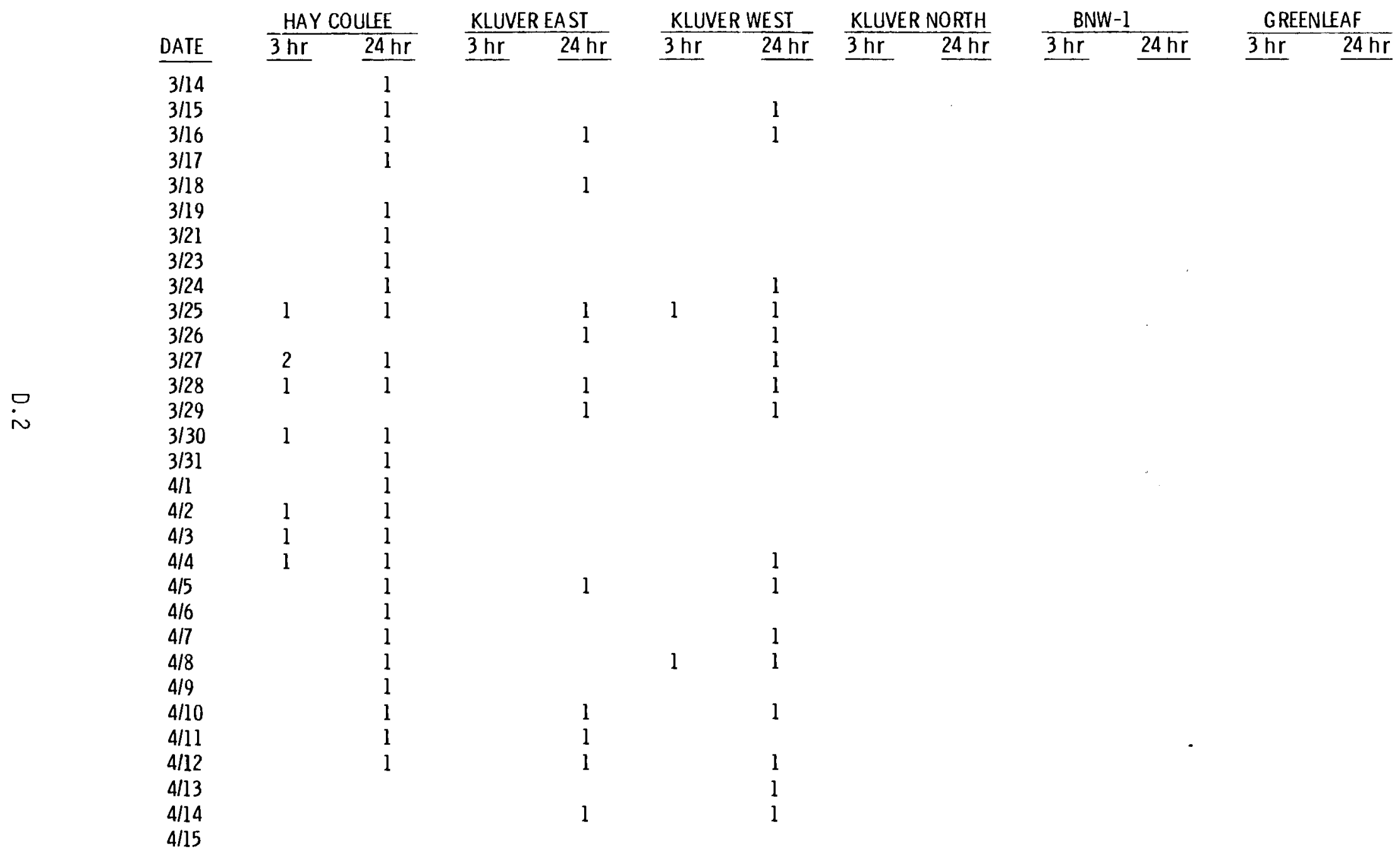


TABLE D.1. (continued)

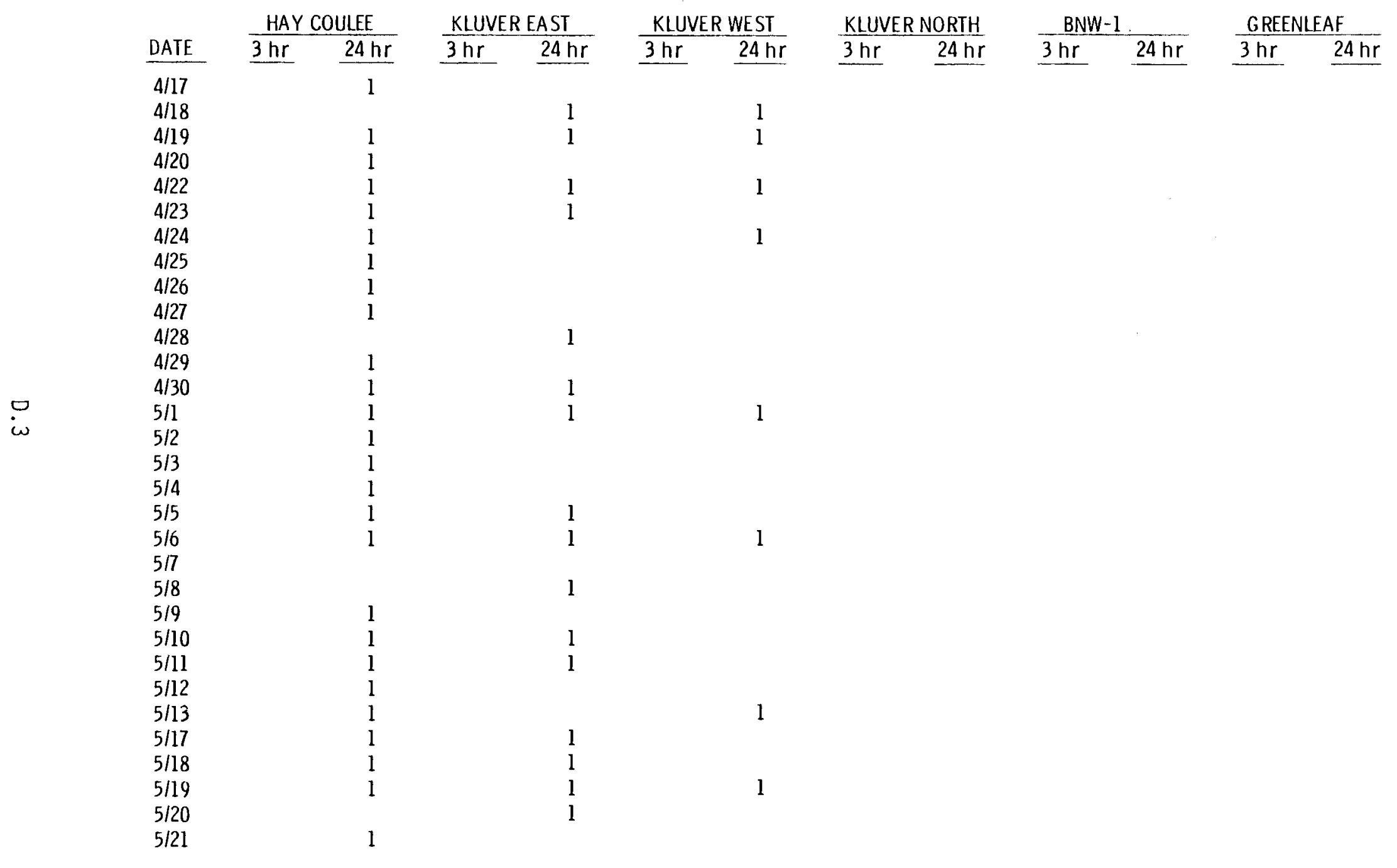


TABLE D. 1. (continued)

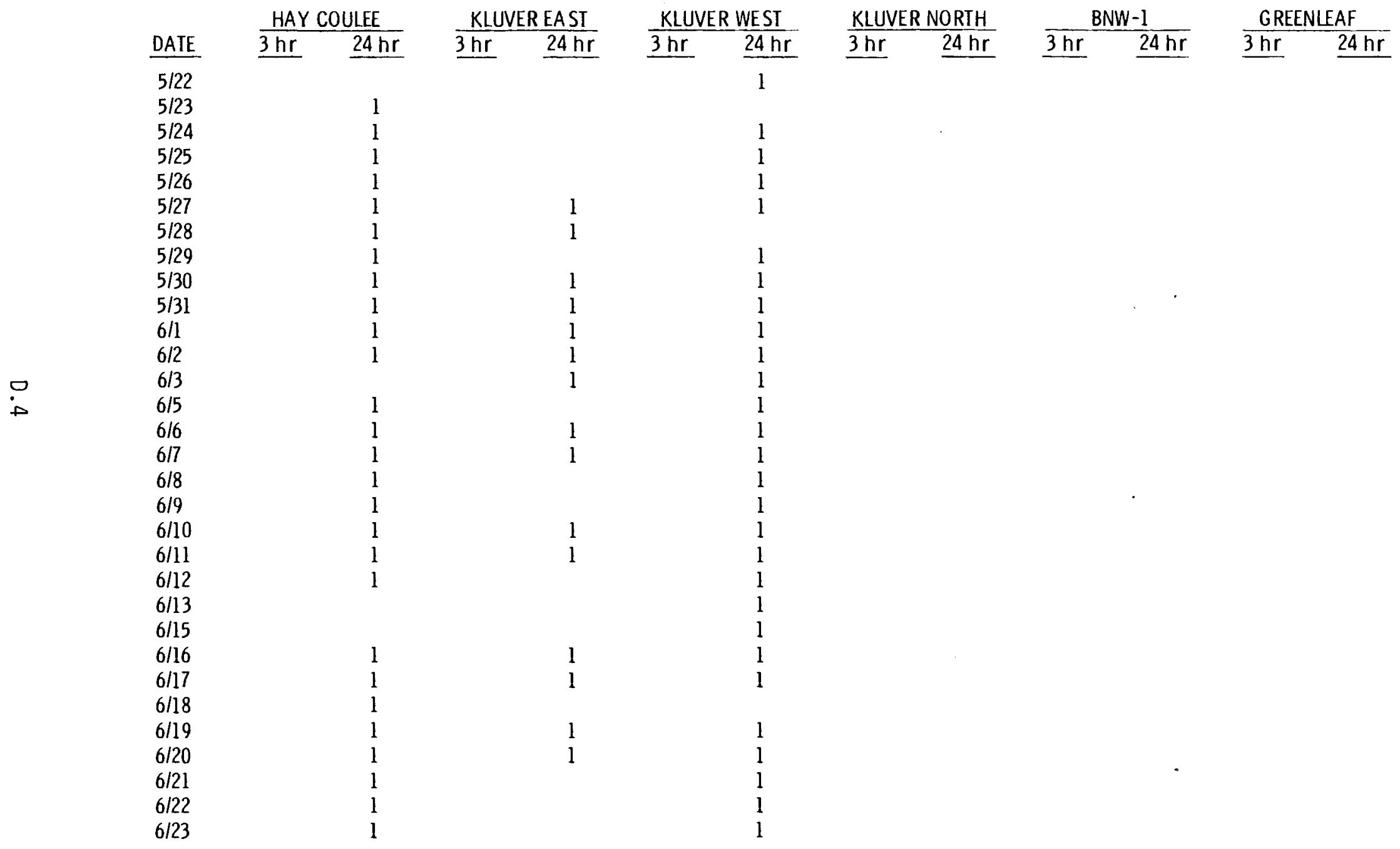


TABLE D.1. (continued)

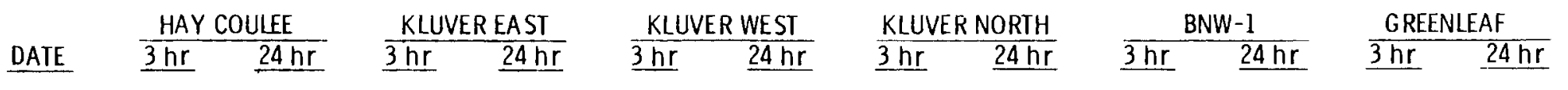

$\begin{array}{lll}1 & & \\ 1 & & 1 \\ 1 & & 1 \\ 1 & 1 \\ 1 & & 1 \\ 1 & & 1 \\ & 1 & 1 \\ & 1 & 1 \\ 1 & & \\ 1 & 1 & 1 \\ 1 & & 1 \\ 1 & & \end{array}$

l
1

1

1
1
1
1
1
1
1 
TABLE D.1. (continued)

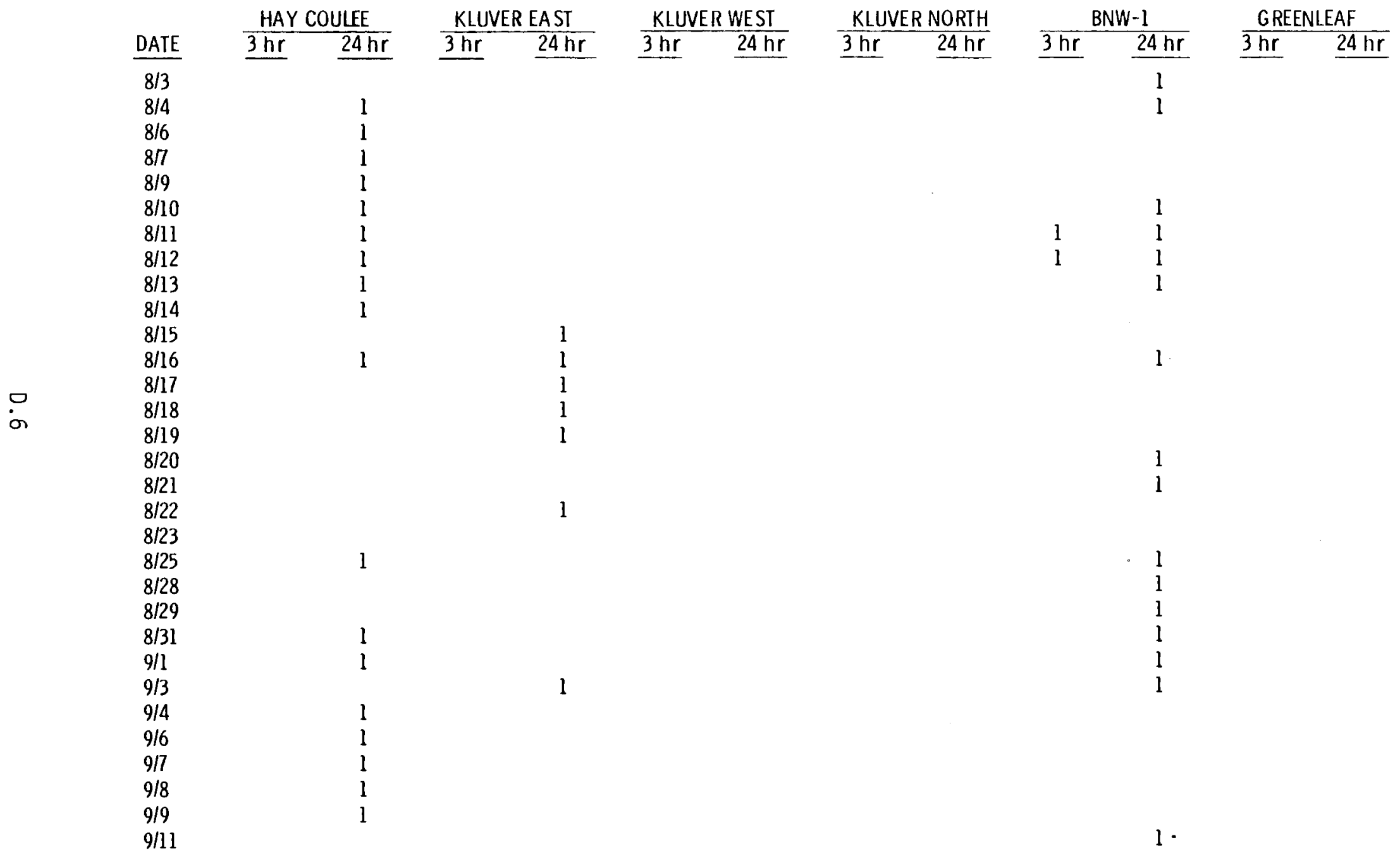


TABLE D. 1. (continued)

\begin{tabular}{|c|c|c|c|c|c|c|c|c|c|c|c|c|}
\hline & & ULEE & $\mathrm{KLU}$ & EAST & $\mathrm{KLU}$ & WEST & KLUI & NORTH & & & GRI & EAF \\
\hline DATE & $3 \mathrm{hr}$ & $24 \mathrm{hr}$ & $3 \mathrm{hr}$ & $24 \mathrm{hr}$ & $3 \mathrm{hr}$ & $24 \mathrm{hr}$ & $3 \mathrm{hr}$ & $24 \mathrm{hr}$ & $3 \mathrm{hr}$ & $24 \mathrm{hr}$ & $3 \mathrm{hr}$ & $24 \mathrm{hr}$ \\
\hline $9 / 12$ & & l & & & & & & & & l & & \\
\hline $9 / 13$ & & & & & & & & & & l & & \\
\hline $9 / 14$ & & & & 1 & & & & & & l & & \\
\hline $9 / 15$ & & & & & & & & & & & & \\
\hline $9 / 16$ & & 1 & & & & & & & & 1 & & \\
\hline $9 / 17$ & & & & & & & & & & l & & \\
\hline $9 / 18$ & & 1 & & & & & & & & & & \\
\hline $9 / 19$ & & 1 & & & & & & & & 1 & & \\
\hline $9 / 20$ & & & & l & & & & & & l & & \\
\hline 9/21 & & & & 1 & & & & & & & & \\
\hline $9 / 22$ & & & & & & & & & & l & & \\
\hline $9 / 24$ & & 1 & & & & & & & & & & \\
\hline $9 / 25$ & & & & l & & & & & & & & \\
\hline $9 / 28$ & & 1 & & & & & & & & & & \\
\hline $9 / 29$ & & 1 & & & & & & & & & & \\
\hline $10 / 2$ & & 1 & & & & & & & & 1 & & \\
\hline $10 / 3$ & & 1 & & & & & & & & 1 & & \\
\hline $10 / 4$ & & & & & & & & & & 1 & & \\
\hline $10 / 5$ & & 1 & & 1 & & & & & & 1 & & \\
\hline $10 / 6$ & & 1 & & 1 & & & & & & & & \\
\hline $10 / 12$ & & 1 & & & & & & & & l & & 1 \\
\hline $10 / 13$ & & 1 & & & & & & & & l & & \\
\hline $10 / 14$ & & 1 & & & & & & & & & & \\
\hline $10 / 16$ & & & & & & & & & & l & & \\
\hline $10 / 17$ & & 1 & & & & & & & & l & & \\
\hline $10 / 18$ & & 1 & & & & & & & & 1 & & 1 \\
\hline $10 / 19$ & & & & & & & & & & & & \\
\hline $10 / 20$ & & & & & & & & & & 1 & & \\
\hline $10 / 21$ & & 1 & & & & & & & & 1 & & \\
\hline $10 / 22$ & & 1 & & & & & & & & 1 & & \\
\hline $10 / 23$ & & l & & & & & & & & 1 & & \\
\hline
\end{tabular}


TABLE D. 1. (continued)

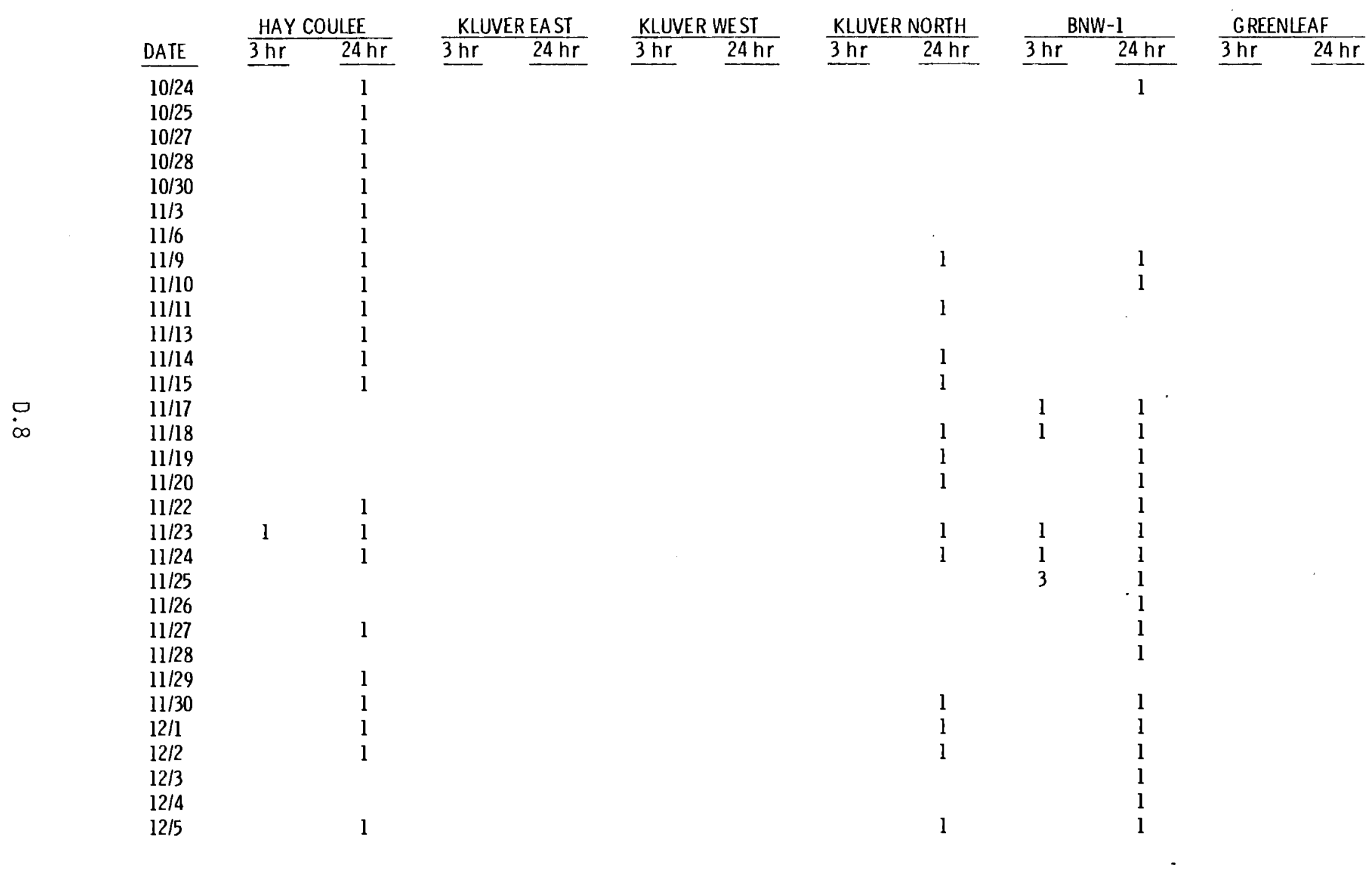


TABLE D.1. (continued)

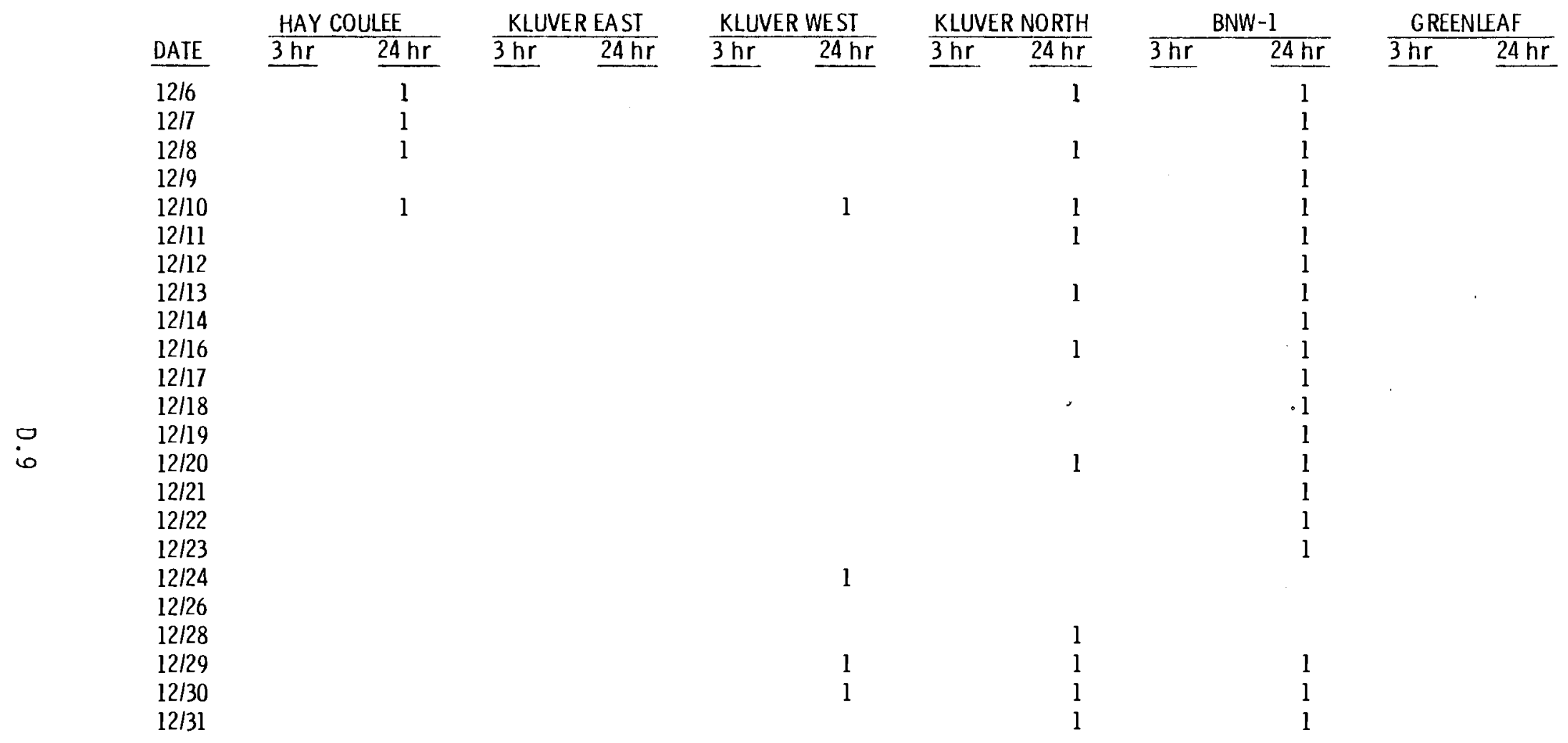




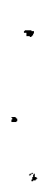


APPENDIX E

POWER PLANT PLUME FUMIGATIONS 
TABLE E. . Power Plant Plume Intercepts at Hay Coulee

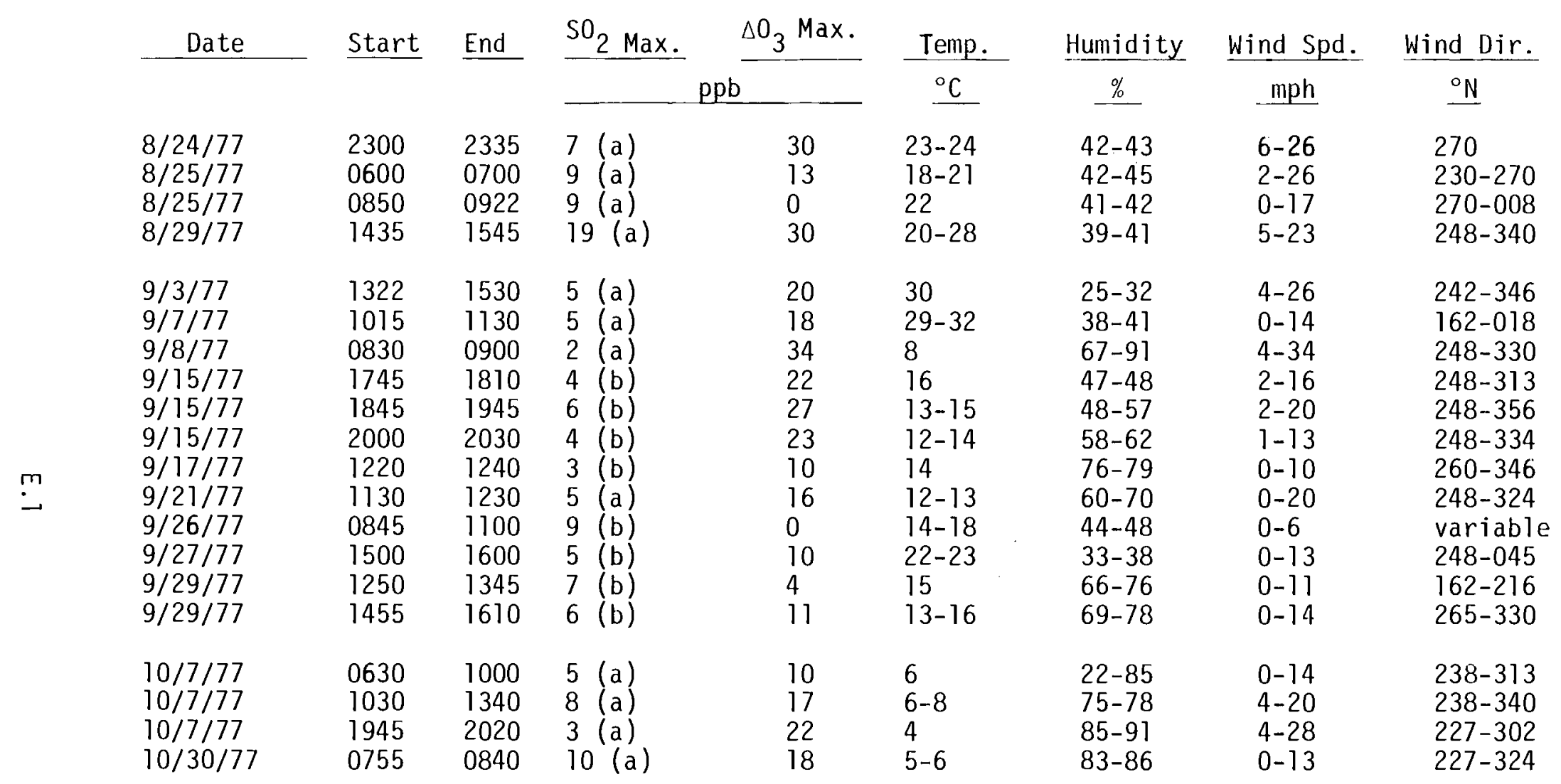

The letters following the sulfur values denote which of three analyzers was utilized to collect the data. At times more than one analyzer were run side by side for comparison.

(a) Meloy 285

(b) Monitor Labs 8450

(c) Meloy 160

To convert $\mathrm{ppb} \mathrm{SO}_{2}$ to micrograms $\mathrm{SO}_{2} / \mathrm{m}^{3}$ at the Hay Coulee altitude multiply ppb values by the constant 2.31 . 
Table E.1. (continued)

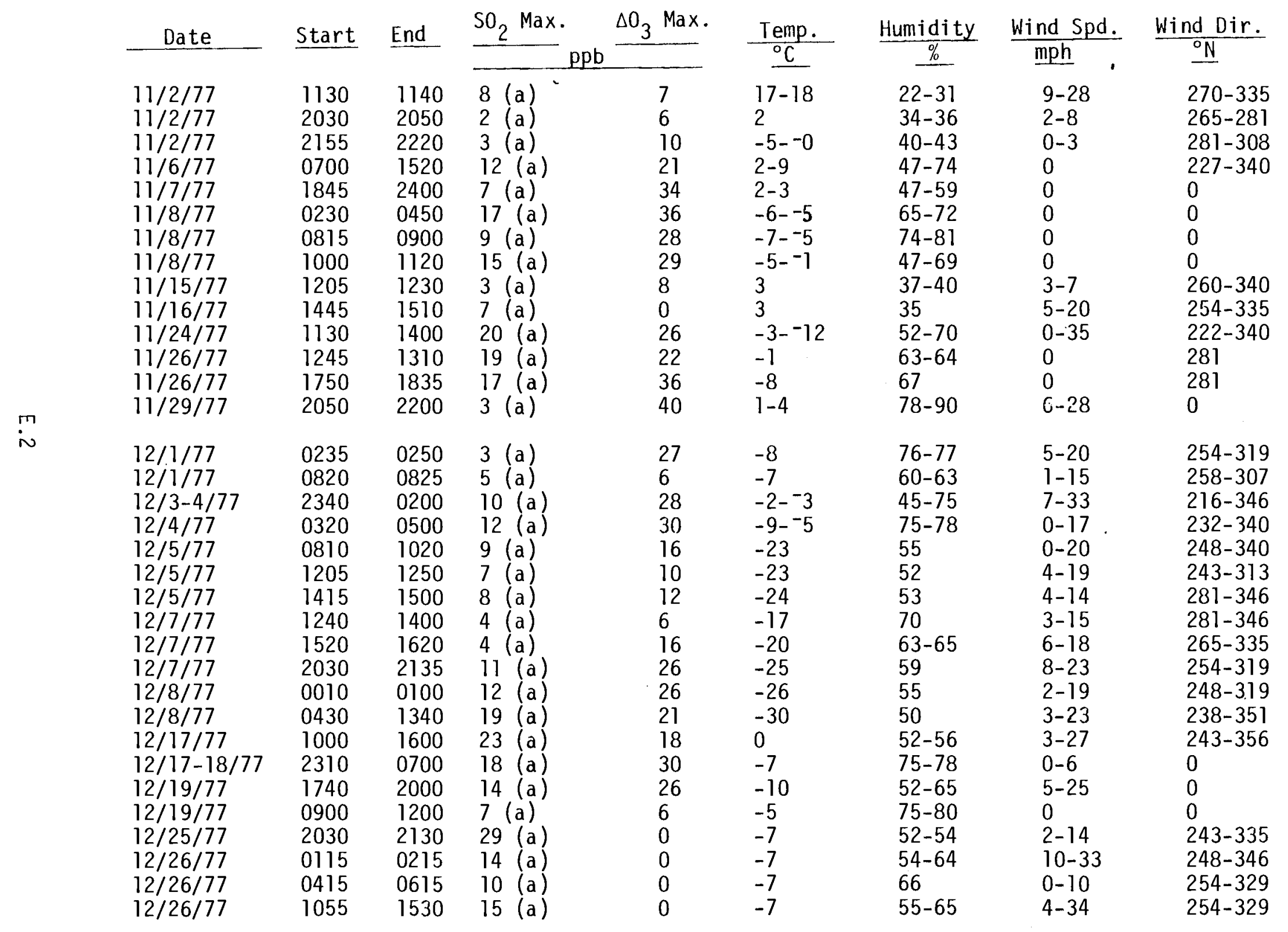


Table E.1. (continued)

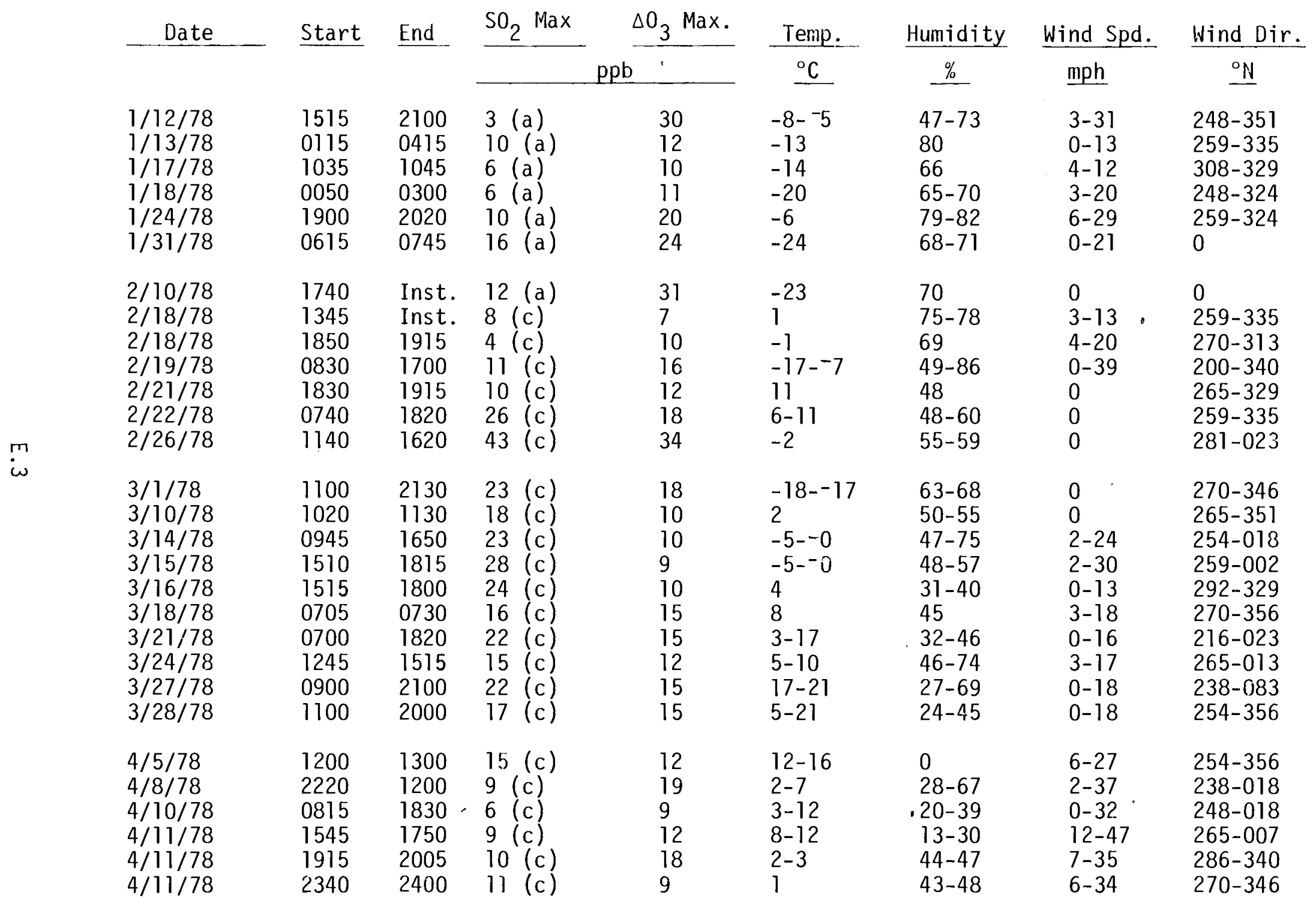


Table E.1. (continued)

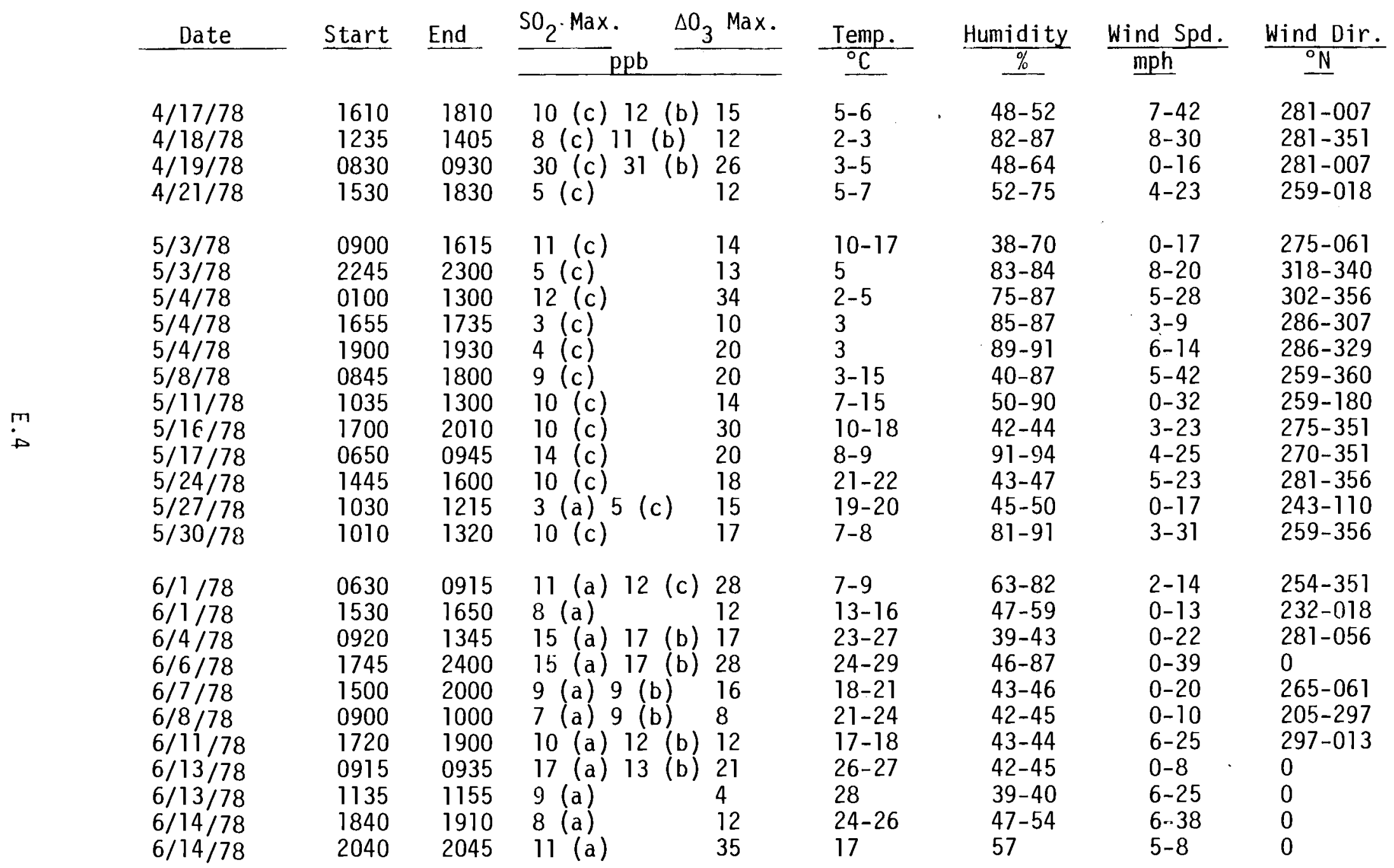


Table E.1. (continued)

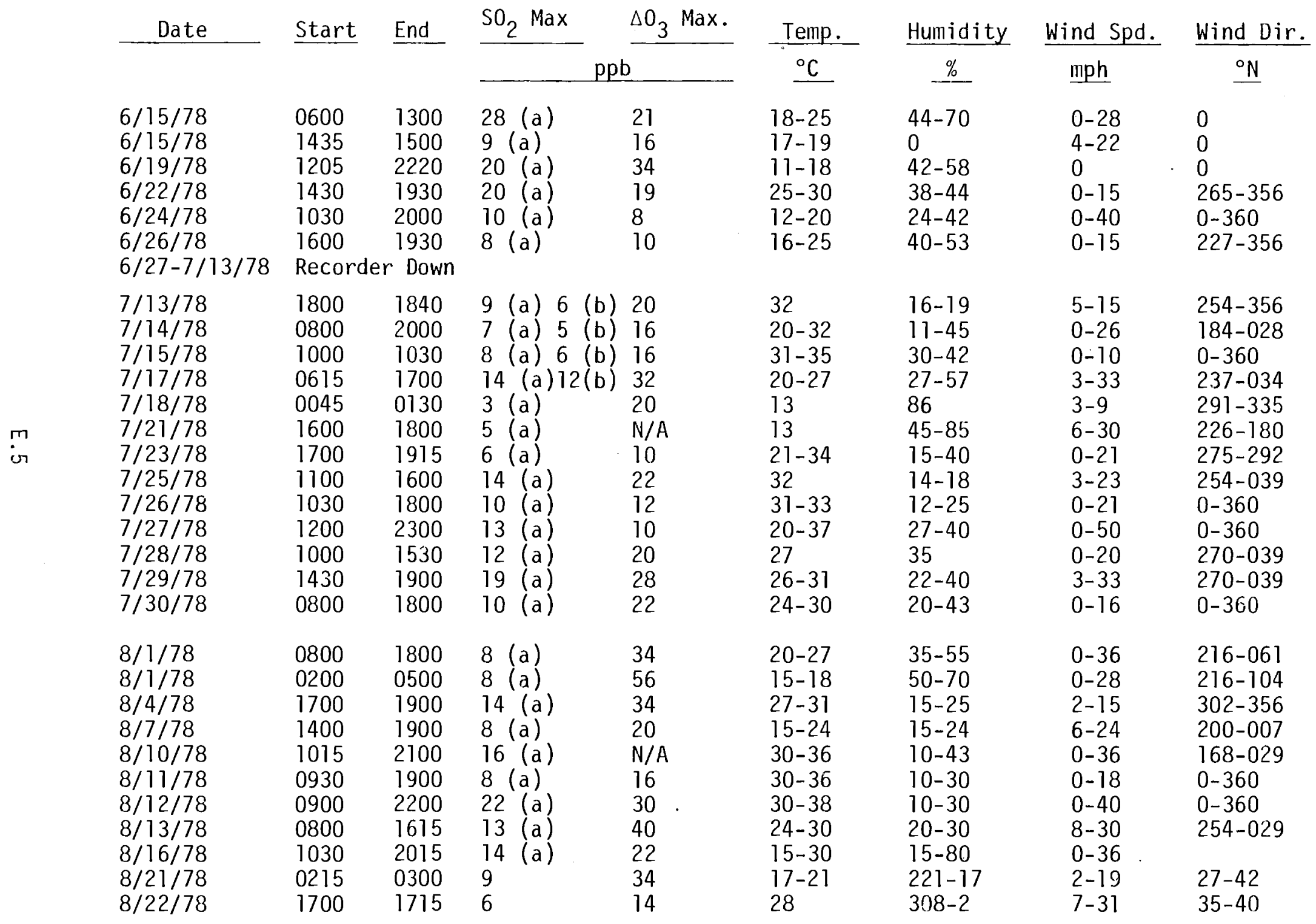


Table E.1. (continued)

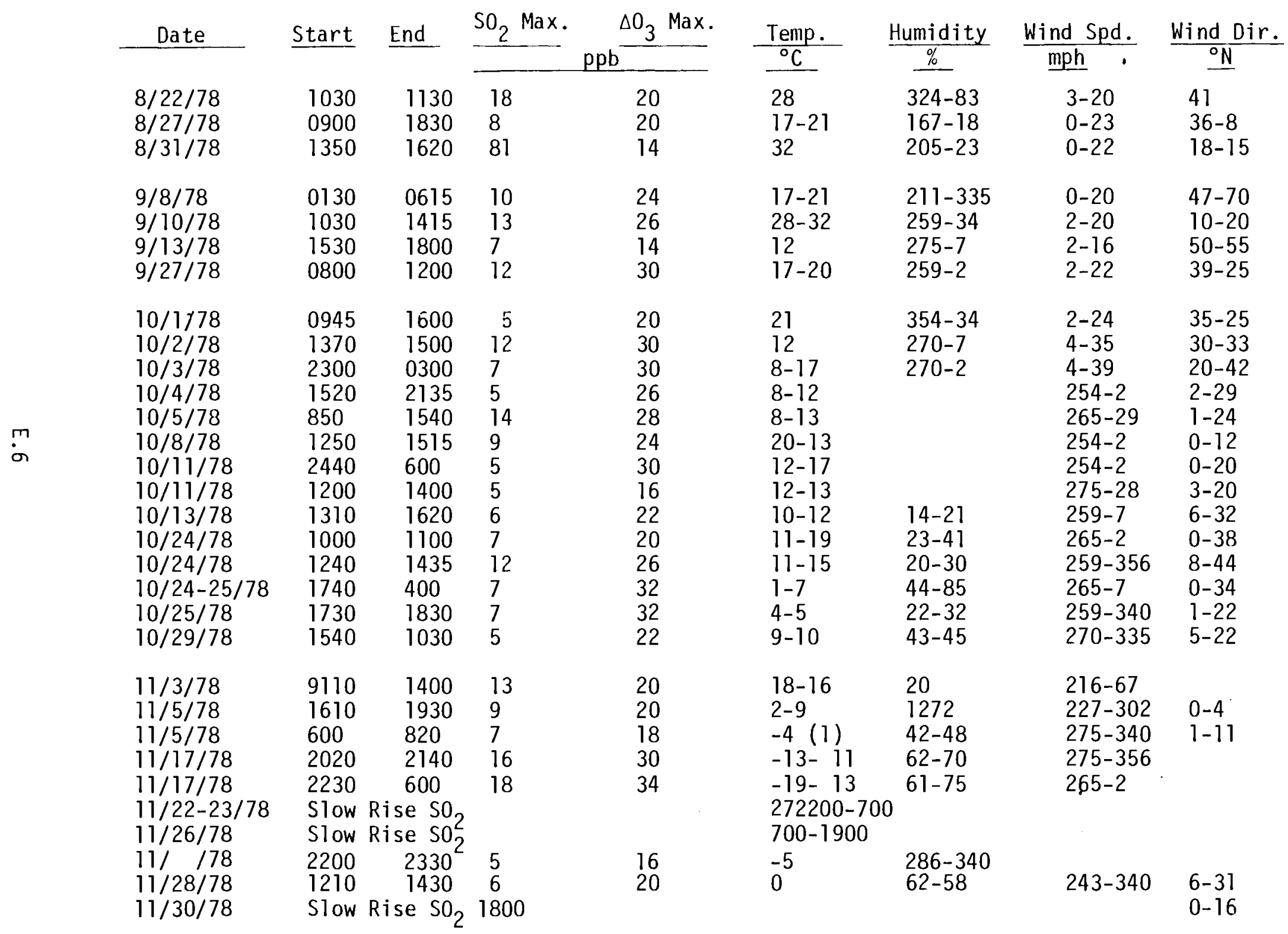


Table E.1. (continued)

\begin{tabular}{|c|c|c|c|c|c|c|c|c|}
\hline Date & Start & End & $\mathrm{SO}_{2} \operatorname{Max}$ & $\Delta 0_{3}$ Max. & \multirow{2}{*}{$\frac{\text { Temp. }}{{ }^{\circ} \mathrm{C}}$} & \multirow{2}{*}{ Humidity } & \multirow{2}{*}{$\frac{\text { Wind Spd. }}{\underline{m p h}}$} & \multirow{2}{*}{$\frac{\text { Wind Dir. }}{{ }^{\circ} \mathrm{N}}$} \\
\hline & & & & & & & & \\
\hline $\begin{array}{l}12 / 4 / 78 \\
12 / 4 / 78 \\
12 / 5 / 78 \\
12 / 6 / 78 \\
12 / 8 / 78 \\
12 / 12 \\
12 / 12 \\
12 / 16 \\
12 / 17\end{array}$ & $\begin{array}{l}230 \\
2215 \\
1500 \\
1130 \\
\text { S10w } \\
1220 \\
1620 \\
\text { S10w } \\
\text { S10w }\end{array}$ & $\begin{array}{c}240 \\
2240 \\
1600 \\
1200 \\
\text { Rise } \mathrm{SO}_{2} \\
1330^{2} \\
1730 \\
\text { rise } \mathrm{SO}_{2} \\
\text { rise } \mathrm{SO}_{2}\end{array}$ & $\begin{array}{l}6 \\
5 \\
6 \\
9 \\
500-1700 \\
10 \\
9\end{array}$ & $\begin{array}{l}24 \\
16 \\
10 \\
12 \\
12 \\
10 \\
100-1400 \\
730-12\end{array}$ & $\begin{array}{l}-1.4 \\
-9 \\
-14-71 \\
-16 \\
-4 \\
-7--6 \\
7\end{array}$ & $\begin{array}{l}81-84 \\
75-78 \\
60-50 \\
57-55\end{array}$ & $\begin{array}{l}292-335 \\
254-302 \\
275-340 \\
281-335 \\
21.6-302 \\
275-346 \\
281-329\end{array}$ & $\begin{array}{l}5-16 \\
3-12 \\
7-20 \\
7-20 \\
5-27 \\
5-20 \\
4-19 \\
0-20\end{array}$ \\
\hline
\end{tabular}


TABLE E.2. Power Plant Plume Intercepts BNW \#1

\begin{tabular}{|c|c|c|c|c|c|c|c|c|}
\hline Date & $\underline{\text { Start }}$ & End & $\begin{array}{c}\mathrm{S}_{0} \mathrm{x}_{\max } \\
\mathrm{ppb}\end{array}$ & $\begin{array}{c}\Delta 0_{3} \max . \\
\mathrm{ppb}\end{array}$ & $\begin{array}{c}\text { Temp. } \\
{ }^{\circ} \mathrm{F} \\
\end{array}$ & Humidity & Wind Spd. & Wind Dir. \\
\hline $\begin{array}{l}7 / 21 / 78 \\
7 / 21 / 78 \\
7 / 23 / 78 \\
7 / 23 / 78 \\
7 / 23 / 78 \\
7 / 24 / 78 \\
7 / 25 / 78 \\
7 / 25 / 78 \\
7 / 26 / 78 \\
7 / 26 / 78 \\
7 / 27 / 78 \\
7 / 28 / 78 \\
7 / 28-7 / 29 / 78 \\
7 / 29 / 78 \\
7 / 29 / 78 \\
7 / 29-7 / 30 / 78 \\
7 / 30 / 78\end{array}$ & $\begin{array}{l}0830 \\
1600 \\
0630 \\
1220 \\
1720 \\
0045 \\
0915 \\
1630 \\
0630 \\
0945 \\
1415 \\
0945 \\
2030 \\
0300 \\
1610 \\
2310 \\
0650\end{array}$ & $\begin{array}{l}1500 \\
1700 \\
0800 \\
1345 \\
1830 \\
0200 \\
1430 \\
1720 \\
0720 \\
1300 \\
1715 \\
1800 \\
0300 \\
0.615 \\
1840 \\
0030 \\
1645\end{array}$ & $\begin{array}{l}8(a) \\
8(a) \\
11(a) \\
14(a) \\
20(a) \\
13(a) \\
47(a) \\
14(a) \\
15(a) \\
17(a) \\
19(a) \\
37(a) \\
62(a) \\
10(a) \\
44(a) \\
13(a) \\
29(a)\end{array}$ & $\begin{array}{l}12 \\
20 \\
32 \\
30 \\
30 \\
28 \\
42 \\
24 \\
26 \\
36 \\
20 \\
40 \\
62 \\
20 \\
40 \\
16 \\
40\end{array}$ & $\begin{array}{l}63-73 \\
69 \\
70-82 \\
93-100 \\
84-89 \\
72 \\
80-90 \\
86 \\
80 \\
89-93 \\
90-99 \\
74-80 \\
69-83 \\
69 \\
78-84 \\
61-66 \\
67-86\end{array}$ & & & \\
\hline
\end{tabular}

(a) Monitor Labs 8450 
Table E.2. (continued)

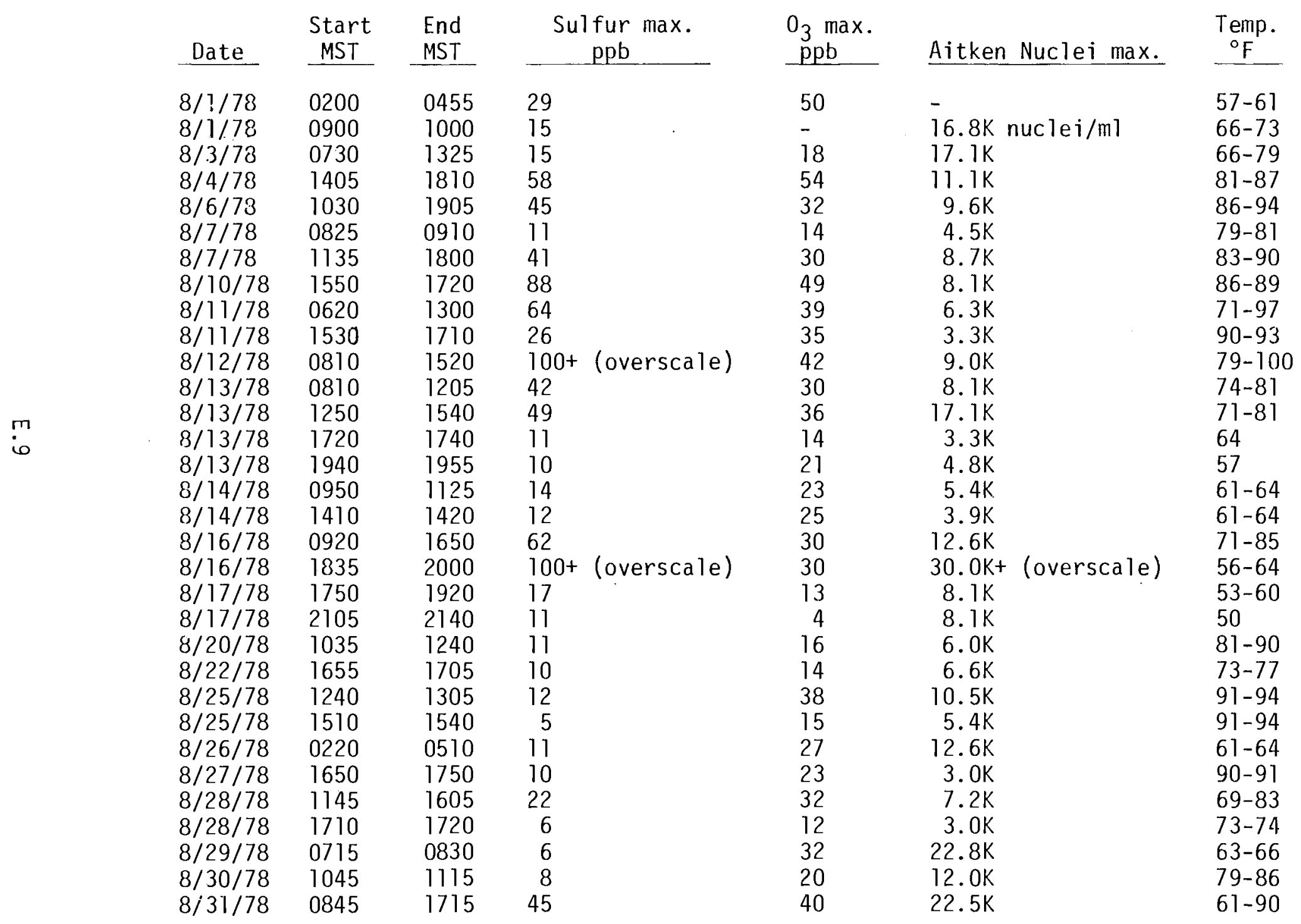


Table E.2. (continued)

\begin{tabular}{|c|c|c|c|c|c|c|}
\hline Date & $\begin{array}{c}\text { Start } \\
\text { MST }\end{array}$ & $\begin{array}{l}\text { End } \\
\text { MST }\end{array}$ & Sulfur max. & $\begin{array}{c}03 \max . \\
\mathrm{ppb}\end{array}$ & Aiken Nuclei max. & $\begin{array}{l}\text { Temp. } \\
{ }^{\circ} \mathrm{F}\end{array}$ \\
\hline $\begin{array}{l}9 / 1 / 78 \\
9 / 2 / 78 \\
9 / 2 / 78 \\
9 / 3 / 78 \\
9 / 3 / 78 \\
9 / 4 / 78 \\
9 / 4 / 78 \\
9 / 5 / 78 \\
9 / 5 / 78 \\
9 / 5 / 78 \\
9 / 6 / 78 \\
9 / 8 / 78 \\
9 / 8 / 78 \\
9 / 8 / 78 \\
9 / 8 / 78 \\
9 / 8 / 78 \\
9 / 10 / 78 \\
9 / 10 / 78\end{array}$ & $\begin{array}{l}1750 \\
1800 \\
2105 \\
1615 \\
2205 \\
0220 \\
2100 \\
1220 \\
1430 \\
2315 \\
1055 \\
0105 \\
1235 \\
1345 \\
1535 \\
1630 \\
0905 \\
1040\end{array}$ & $\begin{array}{l}2255 \\
1915 \\
2120 \\
1725 \\
2220 \\
0515 \\
2135 \\
1325 \\
1955 \\
2345 \\
1325 \\
0155 \\
1245 \\
1350 \\
1550 \\
1705 \\
0945 \\
1300\end{array}$ & $\begin{array}{r}9 \\
7 \\
6 \\
16 \\
7 \\
6 \\
7 \\
13 \\
21 \\
7 \\
25 \\
16 \\
7 \\
5 \\
7 \\
16 \\
13 \\
21\end{array}$ & $\begin{array}{l}28 \\
20 \\
38 \\
32 \\
24 \\
22 \\
26 \\
22 \\
42 \\
26 \\
34 \\
22 \\
20 \\
18 \\
22 \\
38 \\
26 \\
31\end{array}$ & $\begin{array}{r}11.7 \mathrm{~K} \\
4.2 \mathrm{~K} \\
15.6 \mathrm{~K} \\
8.1 \mathrm{~K} \\
10.5 \mathrm{~K} \\
18.0 \mathrm{~K} \\
3.0 \mathrm{~K} \\
4.5 \mathrm{~K} \\
30.0 \mathrm{~K}+\text { (overscale) } \\
30.0 \mathrm{~K}+\text { (overscale) } \\
4.8 \mathrm{~K} \\
2.3 \mathrm{~K} \\
0.9 \mathrm{~K} \\
0.9 \mathrm{~K} \\
0.9 \mathrm{~K} \\
0.9 \mathrm{~K} \\
0.9 \mathrm{~K} \\
1.2 \mathrm{~K}\end{array}$ & $\begin{array}{l}71-84 \\
83-87 \\
80 \\
90-93 \\
81-83 \\
73-74 \\
79-84 \\
93-91 \\
83-97 \\
76-77 \\
80-89 \\
66-69 \\
74-77 \\
73-74 \\
74-76 \\
74-77 \\
74-77 \\
79-86\end{array}$ \\
\hline
\end{tabular}

The suffix (K) on the Aitken nuclei values denotes multiplication by 1000 .

To convert sulfur values to micrograms/cubic meter, multiply the ppb values by the constant 2.31 . 
Tabie E.2. (cuntinued)

\begin{tabular}{|c|c|c|c|c|c|c|c|c|}
\hline Date & Start & End & $\begin{array}{c}\mathrm{SO}_{2} \max . \\
\mathrm{ppb}\end{array}$ & $\begin{array}{c}\Delta 0_{3} \max . \\
\mathrm{ppb}\end{array}$ & $\begin{array}{l}\text { Temp. } \\
{ }^{\circ} \mathrm{F} \\
\end{array}$ & Wind Dir. & Max. CN & Type \\
\hline $9 / 13 / 78$ & 1515 & 1730 & 23 & 20 & 50 & N.A. & $6 \mathrm{~K}$ & Inter. \\
\hline $9 / 14 / 78$ & 1300 & 1450 & 18 & 20 & 64 & N.A. & $6 \mathrm{~K}$ & Inter. \\
\hline $9 / 18 / 78$ & 1430 & 1030 & 5 & 20 & $50-52$ & N.A. & $3 \mathrm{~K}$ & Inter. \\
\hline $9 / 19 / 78$ & 1645 & 1745 & 5 & 20 & 43 & N.A. & $9 \mathrm{~K}$ & Inter. \\
\hline $9 / 23 / 78$ & 0130 & 0500 & 6 & 22 & $53-57$ & N.A. & $2.4 \mathrm{~K}$ & Inter. \\
\hline $9 / 23 / 78$ & 1600 & 1615 & 8 & 16 & 73 & N.A. & $.7 \mathrm{~K}$ & Inter. \\
\hline $9 / 28 / 78$ & 0800 & 1230 & 19 & 34 & $57-67$ & $295-007$ & $.9 \mathrm{~K}$ & Inter. \\
\hline $9 / 29 / 78$ & 1200 & 1500 & 25 & 34 & $60-65$ & $295-004$ & $.9 \mathrm{~K}$ & Inter. \\
\hline $10 / 1 / 78$ & 0215 & 0315 & 12 & 32 & & $306-360$ & $8.1 k$ & Inter. \\
\hline $10 / 1 / 78$ & 0815 & 1500 & 23 & 34 & $50-67$ & $0-360$ & $10.5 \mathrm{~K}$ & Inter. \\
\hline
\end{tabular}


Table E.2. (continued)

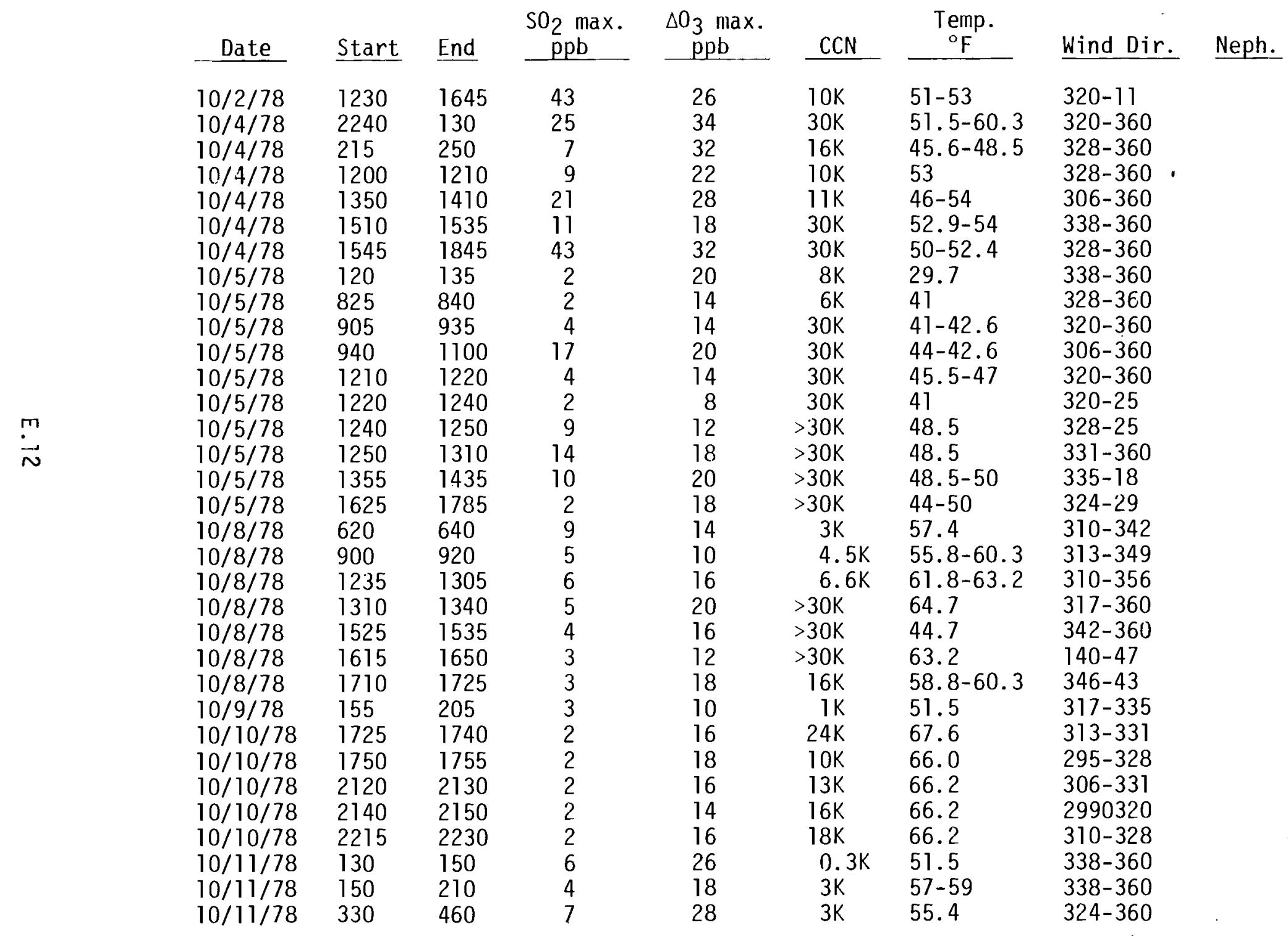


Table E.2. (continued)

\begin{tabular}{|c|c|c|c|c|c|c|c|c|}
\hline Date & Start & End & $\begin{array}{c}\mathrm{SO}_{2} \max . \\
\mathrm{ppb}\end{array}$ & $\begin{array}{c}\Delta 0_{3} \max . \\
\mathrm{ppb} \\
\end{array}$ & $\mathrm{CCN}$ & $\begin{array}{l}\text { Temp. } \\
{ }^{\circ} \mathrm{F}\end{array}$ & Wind Dir. & Neph. \\
\hline $\begin{array}{l}10 / 11 / 78 \\
10 / 11 / 78 \\
10 / 11 / 78 \\
10 / 11 / 78 \\
10 / 11 / 78 \\
10 / 11 / 78 \\
10 / 11 / 78 \\
10 / 11 / 78 \\
10 / 11 / 78 \\
10 / 12 / 78 \\
10 / 12 / 78 \\
10 / 12 / 78 \\
10 / 12 / 78 \\
10 / 12 / 78 \\
10 / 12 / 78 \\
10 / 12 / 78 \\
10 / 12 / 78 \\
10 / 12 / 78 \\
10 / 12 / 78 \\
10 / 12 / 78 \\
10 / 12 / 78 \\
10 / 13 / 78 \\
10 / 14 / 78 \\
10 / 14 / 78 \\
10 / 14 / 78 \\
10 / 16 / 78 \\
10 / 16 / 78 \\
10 / 21 / 78 \\
10 / 24 / 78 \\
10 / 24 / 78 \\
10 / 24 / 78 \\
10 / 24 / 78 \\
10 / 24 / 78\end{array}$ & $\begin{array}{l}1120 \\
1215 \\
1330 \\
1410 \\
1450 \\
1510 \\
1605 \\
2010 \\
2340 \\
2440 \\
730 \\
820 \\
830 \\
910 \\
1030 \\
1130 \\
1210 \\
1220 \\
1250 \\
1320 \\
1550 \\
\text { Zero } \\
1910 \\
1814 \\
1640 \\
1314 \\
1935 \\
0620 \\
1720 \\
1540 \\
1235 \\
1010 \\
1846\end{array}$ & $\begin{array}{c}1140 \\
1245 \\
1440 \\
1430 \\
1505 \\
1535 \\
1635 \\
1045 \\
2355 \\
140 \\
815 \\
845 \\
900 \\
1000 \\
1120 \\
1140 \\
1219 \\
1245 \\
1318 \\
1350 \\
1600 \\
\text { Span } 1315 \\
1918 \\
1900 \\
1735 \\
1318 \\
1950 \\
0640 \\
1820 \\
1645 \\
1350 \\
1030 \\
1925\end{array}$ & $\begin{array}{r}7 \\
7 \\
5 \\
8 \\
5 \\
9 \\
5 \\
5 \\
4 \\
16 \\
16 \\
4 \\
23 \\
6 \\
3 \\
3 \\
3 \\
6 \\
11 \\
4 \\
3 \\
5-1615 \\
10 \\
5 \\
6 \\
7 \\
6 \\
7 \\
20 \\
7 \\
26 \\
26 \\
12\end{array}$ & $\begin{array}{l}26 \\
14 \\
16 \\
20 \\
10 \\
26 \\
20 \\
16 \\
20 \\
32 \\
24 \\
16 \\
22 \\
10 \\
14 \\
16 \\
14 \\
26 \\
28 \\
16 \\
20 \\
26 \\
16 \\
26 \\
30 \\
12 \\
10 \\
28 \\
24 \\
30 \\
26 \\
26\end{array}$ & $\begin{array}{l}1 \mathrm{~K} \\
1 \mathrm{~K} \\
3 \mathrm{~K} \\
2 \mathrm{~K} \\
0.3 \mathrm{~K} \\
2 \mathrm{~K} \\
1 \mathrm{~K} \\
30 \mathrm{~K} \\
6 \mathrm{~K} \\
15 \mathrm{~K} \\
24 \mathrm{~K} \\
0.3 \mathrm{~K} \\
7.8 \mathrm{~K} \\
1.2 \mathrm{~K} \\
2.4 \mathrm{~K} \\
3.6 \mathrm{~K} \\
7 \mathrm{~K} \\
8.7 \mathrm{~K} \\
14 \mathrm{~K} \\
6.6 \mathrm{~K} \\
26 \mathrm{~K} \\
\\
4.5 \mathrm{~K} \\
17 \mathrm{~K} \\
26 \mathrm{~K} \\
4.8 \mathrm{~K} \\
6 \mathrm{~K} \\
6 \mathrm{~K} \\
24 \mathrm{~K} \\
12 \mathrm{~K} \\
20 \mathrm{~K} \\
10 \mathrm{~K} \\
8 \mathrm{~K}\end{array}$ & $\begin{array}{l}51-54 \\
51-54 \\
53-57 \\
53-54 \\
53-54 \\
54-57.4 \\
47 \\
45.6-47 \\
41.2-42.6 \\
38-39.7 \\
34-39.7 \\
39.7 \\
34-39.7 \\
38.7-42.1 \\
42.6-45.6 \\
45.6 \\
44.8-47.8 \\
46.3 \\
45.6-47 \\
45.6-48.5 \\
45.6-46.3 \\
57.4-58.8 \\
58.1-58.8 \\
58.8-63.2 \\
64.7-66.2 \\
60.3 \\
53 \\
42-43 \\
44-46 \\
53-54 \\
59-63 \\
42\end{array}$ & $\begin{array}{l}162-18 \\
299-18 \\
251-18 \\
169-18 \\
331-47 \\
320-18 \\
313-360 \\
198-40 \\
245-360 \\
249-360 \\
320-360 \\
320-356 \\
281-360 \\
306-356 \\
295-356 \\
184-360 \\
306-360 \\
324-360 \\
295-360 \\
306-360 \\
310-29 \\
310-335 \\
317-346 \\
295-14 \\
65-360 \\
310-344 \\
331-360 \\
\text { N.D. } \\
\text { N.D. } \\
\text { N.D. } \\
313-360\end{array}$ & • \\
\hline
\end{tabular}


Table E.2. (continued)

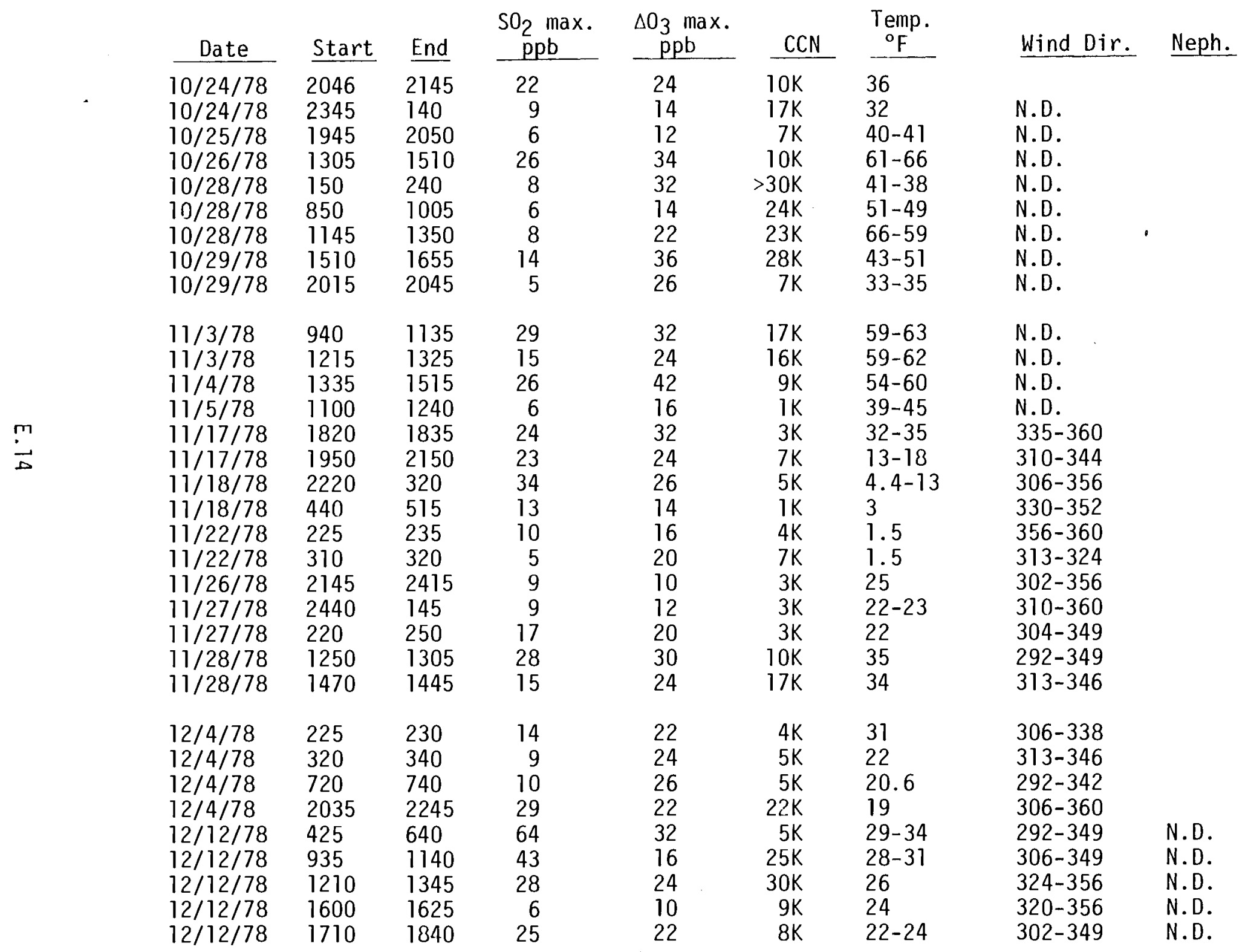


Table E.2. (continued)

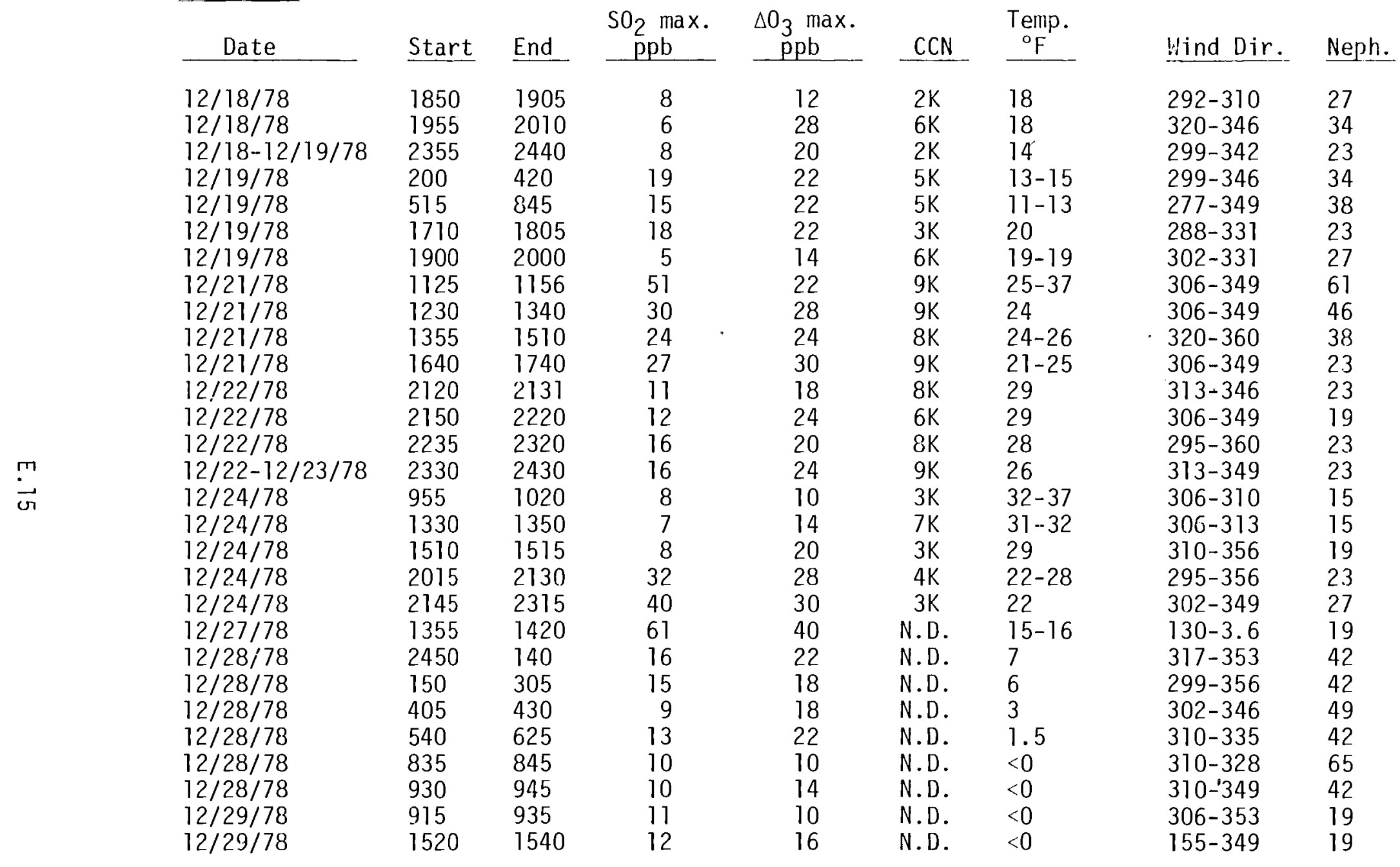


TABLE E.3.A. Power Plant Plume Intercepts Kluver West

\begin{tabular}{|c|c|c|c|c|c|c|}
\hline Date & $\begin{array}{l}\text { Start } \\
\text { MST }\end{array}$ & End & $\begin{array}{c}\mathrm{SO}_{2} \max . \\
\mathrm{ppb}\end{array}$ & $\begin{array}{c}\Delta 0_{3} \max . \\
\mathrm{ppb} \\
\end{array}$ & $\begin{array}{c}\text { Temp. } \\
\text { OF } \\
\end{array}$ & $\begin{array}{c}\text { Wind Dir. } \\
\text { on }\end{array}$ \\
\hline $\begin{array}{l}3 / 28 / 78 \\
3 / 29 / 78 \\
3 / 30 / 78 \\
3 / 30 / 78\end{array}$ & $\begin{array}{l}1430 \\
1028 \\
1204 \\
1512\end{array}$ & $\begin{array}{l}1556 \\
2000 \\
1228 \\
1600\end{array}$ & $\begin{array}{r}5 \\
13 \\
8 \\
5\end{array}$ & & & \\
\hline $\begin{array}{l}4 / 5 / 78 \\
4 / 5 / 78 \\
4 / 8 / 78 \\
4 / 17 / 78\end{array}$ & $\begin{array}{l}0512 \\
0720 \\
0816 \\
0304\end{array}$ & $\begin{array}{l}0612 \\
0808 \\
1124 \\
1008\end{array}$ & $\begin{array}{r}2 \\
8 \\
26 \\
5\end{array}$ & & & \\
\hline $\begin{array}{l}5 / 3 / 78 \\
5 / 10 / 78 \\
5 / 10 / 78 \\
5 / 10 / 78 \\
5 / 10 / 78 \\
5 / 10 / 78 \\
5 / 11 / 78 \\
5 / 12 / 78 \\
5 / 12 / 78 \\
5 / 22 / 78 \\
5 / 24 / 78 \\
5 / 30 / 78\end{array}$ & $\begin{array}{l}1350 \\
1210 \\
1350 \\
1635 \\
1705 \\
1755 \\
1610 \\
0340 \\
0505 \\
0930 \\
0800 \\
1715\end{array}$ & $\begin{array}{l}1430 \\
1235 \\
1355 \\
1645 \\
1725 \\
1845 \\
1700 \\
0405 \\
0600 \\
1100 \\
1330 \\
1730\end{array}$ & $\begin{array}{r}5 \\
9 \\
4 \\
4 \\
4 \\
9 \\
6 \\
3 \\
5 \\
19 \\
19 \\
6\end{array}$ & $\begin{array}{r}18 \\
16 \\
8 \\
14 \\
18 \\
28 \\
22 \\
28 \\
30 \\
16 \\
16\end{array}$ & $\begin{array}{l}67 \\
56 \\
56-57 \\
56-57 \\
58-59 \\
48-56 \\
43 \\
41-44 \\
70-74 \\
61-65 \\
46\end{array}$ & $\begin{array}{l}223-317 \\
259-306 \\
288-310 \\
248-299 \\
259-324 \\
230-306 \\
256-324 \\
263-310 \\
256-313 \\
234-338 \\
266-334 \\
237-266\end{array}$ \\
\hline $\begin{array}{l}6 / 1 / 78 \\
6 / 4 / 78 \\
6 / 5 / 78 \\
6 / 6 / 78 \\
6 / 6 / 78 \\
6 / 6 / 78 \\
6 / 6 / 78\end{array}$ & $\begin{array}{l}1645 \\
1130 \\
1000 \\
0700 \\
1000 \\
1405 \\
1610\end{array}$ & $\begin{array}{l}1700 \\
1330 \\
1800 \\
0830 \\
1245 \\
1430 \\
1715\end{array}$ & $\begin{array}{r}8 \\
11 \\
6 \\
14 \\
15 \\
7 \\
5\end{array}$ & $\begin{array}{l}20 \\
18 \\
10 \\
16 \\
18 \\
10 \\
10\end{array}$ & $\begin{array}{l}54 \\
71-74 \\
71-78 \\
70-74 \\
74-79 \\
71-74 \\
59-63\end{array}$ & $\begin{array}{l}252-324 \\
220-342 \\
250-334 \\
262-324 \\
262-316 \\
194-270 \\
187-338\end{array}$ \\
\hline
\end{tabular}


TABLE E.3.B. Power Plant Plume Intercepts KTuver East

\begin{tabular}{|c|c|c|c|c|c|c|c|}
\hline Date & $\begin{array}{c}\text { Start } \\
\text { MST } \\
\end{array}$ & End & $\begin{array}{l}\mathrm{SO}_{2} \max . \\
-\mathrm{ppb}\end{array}$ & $\begin{array}{c}\Delta 0_{3} \max . \\
\mathrm{ppb}\end{array}$ & Aitken nuclei & $\begin{array}{c}\text { Temp. } \\
{ }^{\circ} \mathrm{F} \\
\end{array}$ & Wind Dir. \\
\hline $5 / 8 / 78$ & 1900 & 1910 & 7 & - & - & 46 & $202-238$ \\
\hline $\begin{array}{l}6 / 1 / 78 \\
6 / 12 / 78 \\
6 / 16 / 78\end{array}$ & $\begin{array}{l}1705 \\
0935 \\
0720\end{array}$ & $\begin{array}{l}1735 \\
1000 \\
1135\end{array}$ & $\begin{array}{r}8 \\
11 \\
13\end{array}$ & $\begin{array}{r}16 \\
4 \\
16\end{array}$ & $\begin{array}{l}0.3 K \\
8.4 K \\
6.3 K\end{array}$ & $\begin{array}{l}57 \\
79-83 \\
64-71\end{array}$ & $\begin{array}{l}238-324 \\
277-331 \\
162-331\end{array}$ \\
\hline
\end{tabular}

The $(K)$ suffix on the Aitken nuclei values denotes multiplication by 1000 .

TABLE E..3.C. Power Plant Plume Intercepts Kluver North

\begin{tabular}{|c|c|c|c|c|c|c|c|}
\hline Date & Start & End & $\begin{array}{c}\mathrm{SO}_{2} \max . \\
\mathrm{ppb} \\
\end{array}$ & $\begin{array}{c}\Delta 0_{3} \max . \\
\mathrm{ppb} \\
\end{array}$ & Aitken nuclei & $\begin{array}{c}\text { Wind Spd. } \\
\text { mph }\end{array}$ & Wind Dir. \\
\hline $7 / 27 / 78$ & 1410 & 2000 & 11 & 8 & $2.3 \mathrm{~K}$ & $0-7$ & $234-072$ \\
\hline $\begin{array}{l}8 / 4 / 78 \\
8 / 4 / 78\end{array}$ & $\begin{array}{l}1120 \\
1221\end{array}$ & $\begin{array}{l}1200 \\
1620\end{array}$ & $\begin{array}{l}5 \\
9\end{array}$ & $\begin{array}{l}20 \\
12\end{array}$ & $\begin{array}{l}7.5 \mathrm{~K} \\
4.4 \mathrm{~K}\end{array}$ & - & $\begin{array}{c}198-360 \\
-\end{array}$ \\
\hline
\end{tabular}


TABLE E.4. Power Plant Plume Intercepts at Greenleaf

\begin{tabular}{|c|c|c|c|c|}
\hline Date & Start & End & $\mathrm{SO}_{2} \operatorname{Max}$. & $\underline{\Delta O}_{3}$ Max. \\
\hline $09 / 23 / 78$ & 1539 & 1600 & 3 & 7 \\
\hline $09 / 25 / 78$ & 1140 & 1154 & 4 & 7 \\
\hline $09 / 28 / 78$ & $0815^{-}$ & 0954 & 7 & 21 \\
\hline $09 / 29 / 78$ & 0754 & 1545 & 6 & 13 \\
\hline $10 / 01 / 78$ & 0636 & -- & 10 & 22 \\
\hline $10 / 02 / 78$ & 0135 & - & 4 & 18 \\
\hline $10 / 04 / 78$ & 0927 & 0945 & 3 & 8 \\
\hline $10 / 29 / 78$ & 1622 & 1630 & 1 & 15 \\
\hline $11 / 03 / 78$ & 1124 & 1303 & 7 & 9 \\
\hline $11 / 04 / 78$ & 2124 & 2151 & 2.5 & 6 \\
\hline
\end{tabular}


No. of

Copies

OFFSITE

A. A. Churm

DOE Patent Division

9800 S. Cass Avenue

Argonne, IL 60439

27 DOE Technical Information Center

Dr. Eric Preston

Environmenta 7 Protection Agency

200 Southwest 35 th

Corvallis, Oregon 97330

ONSITE

DOE Richland Operations Office

H. F. Ransom

36 Pacific Northwest Laboratory

J. D. Ludwick (25)

J. M. Nielsen

R. W. Perkins

L. A. Rancitelli

J. A. Young

Technical Information (5)

Publishing Coordination (2) 


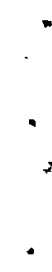

